Stalin's Constitution: Soviet Participatory Politics and the Discussion of the 1936 Draft Constitution

Samantha Lomb 


\section{Stalin's Constitution: Soviet Participatory Politics and the Discussion of the 1936 Draft Constitution}

Upon its adoption in December 1936, Soviet leaders hailed the new so-called Stalin Constitution as the most democratic in the world. Scholars have long scoffed at this claim, noting that the mass repression of 1937-1938 that followed rendered it a hollow document. This study does not address these competing claims, but rather focuses on the six-month-long popular discussion of the draft Constitution, which preceded its formal adoption in December 1936. Drawing on rich archival sources, this book uses the discussion of the draft 1936 Constitution to examine discourse between the central state leadership and citizens about the new Soviet social contract, which delineated the roles the state and citizens should play in developing socialism. For the central leadership, mobilizing its citizenry in a variety of state-building campaigns was the main goal of the discussion of the draft Constitution. However, the goals of the central leadership at times stood in stark contrast with the people's expressed interpretation of that social contract. Citizens of the USSR focused on securing rights and privileges, often related to improving their daily lives, from the central government.

Samantha Lomb is a Dotsent (Assistant Professor) in the Foreign Language Department at Vyatka State University, Kirov, Russia. 


\section{Routledge Studies in Modern European History}

https://www.routledge.com/history/series/SE0246

42 German Reunification

Unfinished Business

Joyce E. Bromley

43 Oil Exploration, Diplomacy, and Security in the Early Cold War The Enemy Underground Roberto Cantoni

44 Divided Village

The Cold War in the German Borderlands

Jason B. Johnson

45 Propaganda, Persuasion and the Great War

Heredity in the Modern Sale of Products and Political Ideas

Pier Paolo Pedrini

46 The Age of Anniversaries

The Cult of Commemoration, 1895-1925

Edited by T. G. Otte

47 The History of the European Migration Regime

Germany's Strategic Hegemony

Emmanuel Comte

48 Governing the Rural in Interwar Europe

Edited by Liesbeth van de Grift and Amalia Ribi Forclaz

49 Stalin's Constitution: Soviet Participatory Politics and the Discussion of the 1936 Draft Constitution

Samantha Lomb 


\section{Stalin's Constitution: Soviet Participatory Politics and the Discussion of the 1936 Draft Constitution}

Samantha Lomb 
First published 2018

by Routledge

2 Park Square, Milton Park, Abingdon, Oxon OX14 4RN

and by Routledge

711 Third Avenue, New York, NY 10017

Routledge is an imprint of the Taylor \& Francis Group, an informa business

(c) 2018 Samantha Lomb

The right of Samantha Lomb to be identified as author of this work has been asserted by her in accordance with sections 77 and 78 of the Copyright, Designs and Patents Act 1988.

The Open Access version of this book, available at www.taylorfrancis. com, has been made available under a Creative Commons Attribution-Non Commercial-No Derivatives 4.0 license.

Trademark notice: Product or corporate names may be trademarks or registered trademarks, and are used only for identification and explanation without intent to infringe.

British Library Cataloguing in Publication Data

A catalogue record for this book is available from the British Library

Library of Congress Cataloging in Publication Data

A catalog record for this book has been requested.

ISBN: 978-1-138-72184-5 (hbk)

ISBN: 978-1-315-19400-4 (ebk)

Typeset in Sabon

by Deanta Global Publishing Services, Chennai, India 
For Tiffany Jean Fleet,

You were the Louise to my Thelma,

my best friend, and I miss your love and support 
This page intentionally left blank 


\section{Contents}

Acknowledgments viii

Archival abbreviations $x$

List of Russian terms $\quad x i$

Introduction 1

1 Citizenship and a social contract: The drafting of the 1936 Constitution $\quad 12$

2 Daily life in Kirov in the 1930s 40

3 Local realities: The implementation of the discussion of the draft Constitution $\quad 62$

4 Validators of socialist victory: The discussion in the local press 84

5 Popular voices: Interpreting citizens' rights and duties 92

6 Integration, exclusion, and accountability 110

7 The Constitution, the 1937 elections, and repression 123

Conclusion 139

Notes on sources $\quad 142$

The draft Constitution of the USSR 146

Bibliography 164

Index 169 


\section{Acknowledgments}

Without the support of many people, this book, the work of over a decade of research, reconceptualization, and revision, would not have been possible. At the top of this list is Bill Chase, my former academic adviser at the University of Pittsburgh. He took a big chance accepting a graduate student who knew no Russian, was incredibly patient and supportive throughout my time as a graduate student, and has continued to give me indispensable advice and guidance. I would also like to thank him for reading the manuscript for this book in various forms many, many times and for always offering in-depth, constructive commentary. Larry Holmes, Professor Emeritus at South Alabama University, also deserves my deepest gratitude for introducing me to Kirov and its amazing archives, helping me establish a life in this wonderful city, and reading many drafts of my work and always providing thoughtful commentary even though I keep making the same mistakes in my writing. Additionally, I would like to thank Aaron Retish, professor at Wayne State University and part time Kirovite, for reading the final version of this manuscript.

I also owe an enormous debt of gratitude to the wonderful staff at the Kirov archives, particularly the staff of the State Archive of Social and Political History of the Kirov Region (GASPI KO), where I have become a regular visitor. I would like to thank the director, Elena Nikolaeva Chudinovskykh, and the deputy director, Olga Anatolevna Malina, for being very welcoming and accommodating. I would also like to thank the reading room staff: Vladimir Sergeevich Zhuravin and Liubov Gennad'evna Poptsova. And a very special thanks to Galina Vasilevna Nagornichnykh for helping me on many occasions to read peasant handwriting. Additionally, I would like to thank my colleagues and students at Vyatka State University for support and help on this project, particularly Andrei Kibishev, Aleksandra Kasimova, and Olga Perevalova for help understanding and translating documents, and a very special thanks to Svetlana Pavlovna (SP) Lebedeva for many wonderful Sunday afternoons at her kitchen table, which helped keep me sane.

Finally, I would like to thank my friends and family, without whose support none of this would have been possible. I would like to thank my mom, Debbie Lomb, who may not initially have understood why I love Russia or 
the point of writing this book, but who has always encouraged me to follow my dreams. My father, Ray Lomb, who did not live to see this project completed, but was always very supportive and proud of me. My cats, Squirtle, Milo, Merida, and Owen, who listened to me reading and rewriting this manuscript, who kept me company through many long hours reading or typing, and who occasionally added their own text. And finally, my best friend, Tiffany Jean Fleet, who spent hours listening to me complain about grad school and Russia, who ordered books for me that I couldn't get in Russia so I could finish this manuscript, who bought me a new laptop so I could keep writing, and who always had faith that I could bring this project to fruition. I dedicate this book to her memory. 


\section{Archival abbreviations}

GARF The State Archive of the Russian Federation

GAKO The State Archive of the Kirov Region

GASPI KO The State Archive of Social and Political History of the Kirov Region 


\section{List of Russian terms}

\begin{tabular}{|c|c|}
\hline Aktiv & $\begin{array}{l}\text { those who actively engaged in political or agitational } \\
\text { work but may not be party members }\end{array}$ \\
\hline Artel' & $\begin{array}{l}\text { workmen's cooperative association; a type of } \\
\text { collective farm with collectivized means of } \\
\text { production but private household property }\end{array}$ \\
\hline Krai & Administrative region/province \\
\hline Kraiispolkom & Regional Executive Committee \\
\hline Kraikom & Regional Party Committee \\
\hline Lishentsy & $\begin{array}{l}\text { people who were deprived of voting rights due to } \\
\text { social class }\end{array}$ \\
\hline Oblast' & Administrative region/province \\
\hline Raion & District (of a city or a rural district) \\
\hline Raiispolkom & District Executive Committee \\
\hline Raikom & District Party Committee \\
\hline Sovnarkom USSR & $\begin{array}{l}\text { Council of Peoples Commissars (equivalent of a } \\
\text { cabinet) }\end{array}$ \\
\hline TsIK & $\begin{array}{l}\text { Central Executive Committee of the Soviet } \\
\text { government }\end{array}$ \\
\hline Zemstvo & $\begin{array}{l}\text { a form of local government that was instituted during } \\
\text { Alexander II's reforms in Imperial Russia }\end{array}$ \\
\hline
\end{tabular}


This page intentionally left blank 


\section{Introduction}

We, the workers of the Regional Forest Administration, noted during the discussion of the draft Constitution that the very fact the draft Constitution was handed over for popular discussion is evidence of our union's powerfully developed might. The historically unprecedented fact that the people developed the Constitution for themselves speaks to the people's energy and [to] our government's strength and stability. ${ }^{1}$

from the Kirov Regional Forest Administration's report on the discussion

Soviet leaders reached out to their citizens from what they believed to be a position of strength, seeking to harness popular enthusiasm and participation to further strengthen and stabilize the Soviet state. In 1935, in response to changing socioeconomic conditions in the USSR, the Party and state elite formed a Constitutional Drafting Commission to revise and then later rewrite the Constitution of the USSR. The committee worked on the new Constitution through June 12, 1936, when a finished draft was submitted to the public for discussion. The discussion of the draft Constitution took place over a period of six months, from June to December 1936. In this sixmonth span, an estimated 42,372,990 people participated in meetings and discussions across the whole USSR, ${ }^{2}$ during which Soviet citizens made over 43,000 suggested changes to the draft Constitution. ${ }^{3}$

While the six-month-long public discussion did not result in substantive changes to the draft Constitution, it did involve Soviet citizens in a public dialogue unlike any since the revolution. This book examines the discourse between the central state leadership and citizens about the new Soviet social contract, which delineated what roles the state and the citizens should play in developing socialism and what the responsibilities of each were. For the central leadership, mobilizing its citizenry in a variety of state-building campaigns was the main goal of the discussion of the draft Constitution. Central state actors tried to develop enduring institutional forms for territorial administration, military-coercive power, revenue extraction, and other socioeconomic functions through such campaigns. ${ }^{4}$ However, the 


\section{Introduction}

goals of the central leadership at times stood in stark contrast with the people's expressed interpretation of that social contract. Citizens of the USSR focused on securing rights and privileges, often related to improving their daily lives, from the central government, but also made known their support of and opposition to aspects of the draft Constitution.

Stalin's Constitution shifts the focus from Moscow and explores broader issues of state building and state-citizen relations by recognizing the agency of local actors and decentralizing the historical narrative. The scope of the all-Union discussion, with over 40 million participants, makes it impossible to study it as a national campaign in any meaningful way. A focused case study enables an examination and contextualization of the often-conflicting agendas of the national government, local and regional officials, and of the populace. This book uses the Kirov region, which is located about 550 miles northeast of Moscow, to examine this campaign. Kirov is ideal for a regional study because the debate there was animated and wide-ranging, and the regional archives are exceptionally rich in materials. As the Kirov region was beyond the line of German occupation, the archives were never damaged or evacuated. Therefore, documents not found elsewhere, such as letters and district-level reports, exist in abundance in Kirov's two main archives: the State Archive of the Kirov Region (GAKO), the main state archive for the region, and the State Archive of the Social and Political History of the Kirov Region (GASPI KO), the archive of the region's Communist Party. ${ }^{5}$

Utilizing these archival sources, this work provides ample evidence that Soviet citizens, particularly collective farm workers, engaged with the state and pressed for some resolution of their local and larger concerns and voiced their complaints about local governance. Regional studies such as this one demonstrate that the Soviet citizens were not without agency and, in fact, often shrewdly sought to manipulate state goals, rhetoric, and campaigns to their own ends. But as this book argues, the people did not always speak with one voice. Urban residents and rural residents, and at times different generations, often had divergent views on various issues, as did local elites and the mass population. Such differences should not be surprising given that the individual experiences of the region's population differed. This study sheds insight into the different perspectives expressed by the residents of the Kirov region and argues that where one worked, one's life experience, and one's personal values influenced citizens' views on the draft Constitution. As such, it provides a counterpoint to the work of historians who have written about aspects of the discussion of the draft Constitution and the implementation of Stalinist campaigns and policies in general, but have done so on a national scale and from the perspective of the central leadership in Moscow.

The literature on the popular discussion of the 1936 Constitution is sparse. Some historians, such as Robert Tucker and Sarah Davies, write about the Constitution in passing and focus on the failure of the state to honor the promises made in the Constitution. Davies in particular focuses 
on the dissonance created when Soviet citizens compared the promises made in the Constitution with the realities of their lives. ${ }^{6}$ Others, such as Ellen Wimberg, focus on how Soviet leaders used the Constitution to promote their own agenda, investigating the formulation of the draft Constitution and the discussion of that draft in the Soviet press as a way to examine tensions between various Party leaders at the time, particularly focusing on Bukharin. ${ }^{7}$ J. Arch Getty, G. I. Tret'iakov, and Andrei Sokolov provide good overviews on the development of the drafting commission and the discussion on a national scale, including the most popular additions, corrections, and suggestions, and how these suggestions influenced the final draft of the Constitution. ${ }^{8}$ Both Getty and Sokolov note that many Soviet citizens took advantage of this open forum to agitate for personal and local issues. This study makes the same point. However, because these published studies' examination of suggestions relies on Central Executive Committee archival materials, their evidence is akin to snapshots from throughout the USSR and is difficult to interpret except in broad terms. Getty himself admits that, "without detailed studies of the Soviet countryside in the 1930's, it is difficult to interpret such data." "This is where a case study like this one provides the much-needed context by framing the discussion within the setting of Stalinist state-building projects and the patterns and concerns of everyday life in the regions. ${ }^{10}$

New regional studies, which allow historians to view how campaigns were implemented on the ground and how local and personal factors affected this implementation, have served to drastically change the way Stalinism and its state-building projects are viewed in Western historiography. Older generations of Western historians often had access only to central publications or, beginning in the early 1990s, to central archival documents and tended to portray Stalinism as a totalitarian and command-style society in which any opening up of society was merely a ploy to mask the Soviet leadership's (or Stalin's) true intentions. For example, Robert Tucker argues that Stalin's main expedient for camouflaging the terror operation in the late 1930s was his rewriting of the Constitution. ${ }^{11}$ Tucker reduces the discussion of the Constitution to a propaganda exercise aggrandizing Stalin, who "was a master of deceit who was making use of the public discussion of the 'most democratic' Constitution as a smokescreen for moves to transform the Soviet regime into something approximating a fascist one." 12

Stalin's Constitution joins a growing list of works which demonstrate that the structure of the state and Party did not guarantee the fulfillment of directives as formulated. In fact, seemingly more often than not, Moscow was frustrated by the less than satisfactory fulfillment of central policies. During the discussion of the draft Constitution, various Central Committee members were frustrated by the improper implementation of the discussion and the casual attitude of many local officials towards having meaningful discussions and recording popular suggestions, as well as the local and personal nature of many suggestions. After the Constitution had been ratified, 
many Soviet leaders were concerned about former class enemies' misuse of new constitutional rights. This constant friction between the goals of the central leadership and the goals of Soviet citizens is reflective of their differing interpretations of the rights and duties of the state and citizens in a socialist society.

The sense of the population as embattled by the state pervades many of the historical studies of the USSR in the 1930s. Lewis Siegelbaum and Andrei Sokolov use the diverse collection of documents presented in Stalinism as a Way of Life to demonstrate how the challenges of building socialism confronted people, often in life-threatening ways, in their daily life. They focus on how citizens negotiated the disruptions that collectivization and rapid industrialization created, but Siegelbaum and Sokolov demonstrate how citizens learned to "speak Bolshevik" and advocate for their own interests within the framework of rhetoric created by the state. ${ }^{13}$ In reference to the draft Constitution, they note,

Seizing the opportunity presented by the Constitution's incorporation of a language of rights, letter writers and participants in formal discussions projected their own ideas, hopes, and resentments onto the document. Their comments and suggestions thus provide an unusual, though not entirely transparent, glimpse into popular mentalities. ${ }^{14}$

Siegelbaum and Sokolov are among the first historians to recognize the bilateral nature of the discussion and central state officials' deep interest in what the people were saying, as well as the plethora of opinions that lay beneath a thin veneer of all-out support for the Party's ideas. ${ }^{15}$

As the centerpiece of Stalin's state-building policies, the drafting, discussion, ratification, and implementation of the 1936 Constitution weaves together many threads: the political course the central leadership wished to set for the country, its ability to mobilize the population, and the ability of the people to engage the state using its own language and to agitate for their own interests and desires. Such negotiations were taking place in the many places where official state policy and citizens' lives intersected. Siegelbaum notes in his study of Stakhanovism that the state was not able to implement Stakhanovism by fiat, but rather the state and its citizens engaged in a sort of dialogue interpreting how Stakhanovism would be enacted through interpenetration of state and personal interests and mutual interdependence. ${ }^{16}$ Stephen Kotkin similarly notes in his groundbreaking micro-history of Magnitogorsk: "it is possible to see-without denying the heavy coercive force of the Communist project-a two-way struggle, however unequal the terms, over the drawing of lines of authority." ${ }^{17}$ In these participatory and collaborative aspects, the designing, drafting, and discussion of the 1936 Constitution mirrors the development of other experimental social endeavors, such as Stakhanovism and the construction of Magnitogorsk. Not only are they contemporaneous state-building projects, but also they were all intended to completely reshape the foundations of society. 
For many historians, there seems to be a contradiction between the fact that the USSR in the 1930s was a one-party dictatorship, aspiring towards strong central control, and the popular participation of the citizenry in actually shaping the parameters of the state. This work argues that there was no contradiction. While the Bolsheviks and the Soviet state had no desire to yield power, both also viewed popular participation in state-sanctioned campaigns as essential. And in fact, the Party sought to mobilize citizens for such campaigns, whether they were in service of collectivization (e.g., the $25,000 \mathrm{ers})^{18}$ or greater worker productivity (e.g., Stakhanovism). As these campaigns demonstrate, the Party and state did not disdain popular participation. On the contrary, they embraced it, albeit within prescribed limits. Popular participation was a way for the Party and state to communicate certain goals and values to the population, as well as a way for the population to help the central state to identify problems with the implementation of these campaigns and local governance. While central authorities deliberately structured such participation, participants often used the opportunity for involvement to convey their own concerns and demands.

As historians begin to examine these campaigns in depth, they have found much negotiating and maneuvering on the part of the cadres charged with implementing state initiatives and the citizens charged with their fulfillment. Siegelbaum notes that the Stakhanovite initiatives of the central leadership were often dramatically transformed as they were interpreted and implemented at the regional and local level. He observes that as initiatives came down from above, they were transformed such that the campaign came to be something less and also something more than was originally foreseen or officially sanctioned. It was not that the central state and Party initiatives stopped at the factory gates, but that what went on beyond them had a profound effect on the formulation and modification of those initiatives, as the management and workers tried to maneuver, accommodate, participate enthusiastically, or resist orders that made their lives more difficult. ${ }^{19}$

Such negotiations are also seen in the other major mass social and economic campaign of the 1930s: collectivization. In his pioneering study on collectivization in Siberia, James Hughes argues that the Soviet leadership employed mass mobilization and materialistic incentives to fracture the peasants as a class and prevent resistance to the regime. Hughes concludes that the "Ural-Siberian method" of collectivization was more successful in part because it relied on the mobilization and organization of poor peasant support. ${ }^{20}$ The Ural-Siberian strategy focused on organizing small groups of poor and middle peasants to act as caucuses to wrest the village assembly from the control of kulaks (prosperous peasants) and then use the legitimacy of said assembly as the governing peasant institution to vote approval for Party policies. Hughes notes that participation in both collectivization and these peasant caucuses was secured by providing selective material incentives, including excludable benefits (from grain bounties, to free goods from cooperative stores, and to a share of looted kulak property) for poor peasants who supported the state. ${ }^{21}$ According to Hughes, 
"the implementation of the social influence (Ural-Siberian) method also had entrenched the 'state building' organizational foundations, bureaucratic structures and institutional procedures which gave the Party powerful levers to control the countryside." 22

The idea of an active citizenry that embraced various aspects of these participatory state-building campaigns is a relatively new idea in Soviet historiography, but it should not be a surprise. In recent years, many good regional studies like Hughes' have allowed historians to investigate the implementation of campaigns at a local level and the negotiations that took place between local and regional state and Party officials and the masses. Charles Hier argues in his study of collectivization campaigns in Sechevka raion, Western Oblast' that local Party and state officials were often lax in implementing collectivization because they were the ones with the most personal property to lose. He documents how local poor peasants worked with regional officials to collectivize the land because of the benefits the state offered to collective farms, such as tractors and high-quality seed. Hier found that many peasants not only embraced collectivization in this region, but also had to actively struggle against local Party and state officials to implement central directives. ${ }^{23}$ In his study of the Kirov region, Aaron Retish likewise notes that peasants embraced and utilized state programs to strengthen their socioeconomic position and to improve their daily lives. He notes that Viatka/Kirov ${ }^{24}$ had a strong tradition of local self-government and advocacy, as peasants were well-represented in the pre-revolutionary zemstvos. During the Civil War, when committees of the poor and other collective organizations were formed, the peasants of the Kirov region embraced them as a way to improve landholdings and gain access to agricultural supplies. While these committees failed quickly in other regions, Retish notes that they endured in the Kirov region and formed the basis for some of the first collective farms here. ${ }^{25}$ The citizens of the Kirov region continually showed great skill in adapting state campaign forms and language to suit their needs. In his study of regional bureaucracy in Kirov in the 1930s, Larry Holmes notes that the regional and local educational bureaucracy adopted the rhetoric of failure and escalating negativity to account for the material and professional failures that plagued the region's schools. Doing so, he argues, helps to explain their use of the language of victimhood to petition for rights and privileges. These administrators were not just passively trying to weather the wrath of the state, but rather used the state's own rhetoric and institutions to settle personal scores and to agitate for personal rights and privileges. ${ }^{26}$

This study uses the discussion of the draft Constitution as a springboard to explore how the state sought to advance its state-building goals by redefining social relations through the use of a social contract, the new Constitution. The state crafted this social contract to help create a stable legal base for society and to promote participation at local and regional levels, as well as a way to make Party and state officials accountable. Like other 
Stalinist campaigns, the discussion of the draft Constitution was often reinterpreted during implementation, making it a forum for negotiating how the state would look at the local level. However, unlike Stakhanovism and other economic campaigns, the discussion of the draft Constitution was designed to solicit citizens' opinions. While the regime's leaders had no doubt anticipated outspoken support for their vision of socialism, this was not always the case, as the participants used the discussion and the state's language to bring local and personal issues to the forefront, and in the process, create a decidedly different interpretation of what the Soviet Union should be. The drafting and discussion of the Constitution provides a unique opportunity to study these negotiations, as the state specifically solicited and meticulously recorded citizen answers and opinions about how the actual legal and theoretical foundations of the state should be formed.

Chapter 1 demonstrates how the draft Constitution highlights the state's attempt to create a new social contract with its citizens and what it expected from them in return. This chapter sets the context for the public discussion, providing an overview of select constitutional thought and theory, which played a role in the drafting of the 1936 Constitution. To this end, this chapter concentrates on the development and evolution of specific articles, which focus on the redefinition of citizens, and citizenship rights, including the re-enfranchisement of former priests and kulaks. It illustrates those aspects of the Constitution, such as increased material benefits, that the central leadership sought to highlight, and how it hoped that the discussion of the draft Constitution would be instrumental in generating enthusiasm for state-building projects.

The second chapter emphasizes the complex realities that shaped daily life and concerns in the primarily rural region by focusing on the demographic, social, and economic situation in post-revolutionary Kirov. Due to the underdeveloped and principally agrarian nature of the region, many of these concerns focused on land, foodstuffs, and material goods needed to survive. Local power struggles, often over access to these daily necessities, were a part of everyday life. These realities significantly shaped the perceptions of its citizens and the complaints and suggestions that they made during the discussion. This chapter makes clear that the citizens of the Kirov region were politically savvy, petitioning for personal interests through the existing channels, such as the local press and local organizations, and using the political language of state campaigns to give these local problems more political significance. This chapter reveals a populace capable of using the discussion of the draft Constitution to agitate for their own interests, and as such, it offers a contrast to the view that Soviet peasants in the 1930s were sullen but apolitical.

Chapter 3 focuses on the implementation of the popular discussion in the Kirov region. This chapter addresses many of the tensions within the Soviet system as revealed by the debate. The central Party and state leadership had a specific vision of how the campaign should unfold. It wanted to enhance 


\section{Introduction}

the process of state building (i.e., the development of enduring institutional forms of administration, military power, and revenue extraction). The new Constitution represented that effort and the Stalinist vision of the state. But unlike past state-building efforts, the Soviet leadership urged citizens to appreciate and discuss the new citizenship rights that the central state leadership had written into the Constitution. This focus was evident in lesson plans created for local Party organizations, which dictated the topics to be covered during the deliberation of the draft. However, the implementation of the discussion was left primarily to local district officials, who tried to balance the debate with the demands of their day-to-day tasks. As a result, many of the local organizers treated the discussion like just another campaign, simply reading the draft Constitution aloud instead of encouraging deliberation. Such treatment drew the ire of the central leadership and then, in turn, of regional officials, who blamed local organizers for a number of "inappropriate suggestions" to the draft. These inappropriate suggestions are revealing, as they focused on individual needs rather than state-building goals. Among them were suggestions to grant collective farmers the same rights as workers and urbanites, and to create peasant unions. This chapter argues that such suggestions were not the result of poor preparatory work, although that was a significant problem, but were a reflection of popular, especially peasant, concerns and demands.

The fourth chapter analyzes the coverage of the popular discussion in Kirovskaia Pravda, the regional newspaper, and several local district newspapers. These newspapers often relied on letters and materials from privileged groups, such as Party members, Stakhanovites, collective farm chair-people, and urban workers, whose ebullient accounts served to validate claims of socialist victory. These materials make clear the stark divide between this small, yet active, relatively educated and privileged population, which had been successfully integrated into the Soviet society, and the peasants who comprised the vast majority of the region's population. This chapter demonstrates that the better-educated and more politically integrated urban dwellers were much more likely to embrace the central government's state-building narrative than were their rural counterparts. Those urban dwellers who wrote letters to newspapers focused on how they were working to create a strong socialist state; many often pledged to work harder in gratitude for their new rights and privileges. Peasants focused much more on local political and economic issues; they had their own ideas about how state power should be used. This chapter makes clear that the well-publicized state-building goals of Party and state leaders were internalized by only a small stratum of citizens, most of whom were members of the urban and working elite, and conveys rural dwellers' hopes and complaints.

Chapter 5 examines the popular suggestions to the draft Constitution put forth by Kirov's citizens. These suggestions provide insight into the issues that preoccupied Kirovites, as well as how they interpreted socialism based on their daily experiences and interactions with the Party and state. This 
chapter focuses in particular on how the reframing of citizenship to include all inhabitants of the USSR, and the expansion of citizens' rights and privileges, became a touchstone for many of the debate's participants. In Kirov, the participants in the discussion focused on including or excluding people from citizenship rights and/or corresponding benefits, while stressing issues that would create safe, stable, and materially secure lives for themselves. Many of the popular suggestions to the draft Constitution focused on vacations, material or monetary aid for collective farmers, land ownership, and access to educational resources. The participants used the rhetorical and political tools that the state had given them to agitate for their interests in order to change state policy. They often cited state policies or their contributions to state-building efforts, such as collectivization, to justify increased material benefits and political equality for themselves or their community. The evidence in this chapter makes clear that many discussants were politically active and engaged in a dialogue with the state so as to promote their interests, which were often drastically different than the needs and expectations that the state had been promoting through its managed discussion of the draft Constitution.

Chapter 6 examines two major aspects of the new draft Constitution: the expansion of electoral and citizenship rights to all people in the USSR, including former kulaks and religious sect members who had been previously stripped of their rights and systematically discriminated against, and the establishment of habeas corpus protections for the accused. This chapter focuses on how, at the local level, citizens accepted what they deemed useful aspects of these policies, while core aspects of these policies, which threatened local stability, were met with much resistance and hostility. Kirovites embraced Stalin's mandate that democracy be a tool for making local officials accountable for their behavior and failures. They had many suggestions to increase their ability to hold local officeholders accountable and demonstrated their willingness to remove incompetent or corrupt officials during the 1936 local elections, which this chapter also discusses. But, Kirovites prized safety and stability, particularly in the countryside where the state was the weakest. As a result, they overwhelmingly rejected habeas corpus protections and the re-enfranchisement of those stripped of their rights, and proposed counter-suggestions that would make it easier for the police and citizens themselves to apprehend criminals.

The final chapter discusses how the subsequent 1937 national elections, based on the new Constitution, contributed to the repression that began that year in Kirov and nationwide. Reports of anti-Soviet activities in the region and instances of formerly disenfranchised people (lishentsy, kulaks) nominating their own candidates for local offices were sent to Moscow. These reports amplified the anxieties that the central leadership had about the perceived increase in enemy activity throughout the country. The local NKVD Party cell minutes, from which many materials are drawn, demonstrated this increased anxiety within the police and the community at large. 
As 1937 progressed, participants at those meetings stopped referring to the infiltration of Soviet organs of power by class enemies as a possibility but rather as a reality that needed to be aggressively confronted. This chapter explores how such reports and pressure from the regions contributed to the onset of mass repression in 1937 and its evolution. As this study examines one region of the Russian Soviet Federative Socialist Republic (RSFSR), the purpose of this chapter is not to make overstated claims about the mass repression, but to show ways in which local issues and state concerns overlapped. In this way, it contributes to the recent literature on the repression, while also raising questions about popular involvement.

Stalin's Constitution concludes that the opening up of the electoral franchise combined with the open forum of the discussion encouraged many Soviet citizens to engage the state in a dialogue about their needs and responsibilities. The locally and personally oriented needs and suggestions of the citizenry were contrary to the suggestions that the state had expected. When citizens, particularly those from already suspect groups, began using their rights to agitate for these personal interests, it heightened central anxieties to the point that it contributed to mass repression in 1937. This step back from the centralized focus of the other historical works on the constitutional discussion sheds light on how citizens understood the roles they and the state should play in developing socialism and what the responsibilities of each were.

\section{Notes}

1 GASPI KO, f. 1293, op. 2, d. 43, 1. 8.

2 This is the number provided by Andrei Sokolov in "Konstitutsiia 1936 goda i kul'turnoe nasledie stalinskogo sotsializma," Sotsial'naia istoriia: ezhegodnik (St. Petersburg: 2008), 140. A higher number (51.5 million people, or 55 percent of the country's adult population) is provided by G. I. Tret'iakov, "Soobshcheniia. Vsenarodnoe obsuzhdenie proekta konstitusii SSSR," Voprosy istorii, No. 9 (September 1953), 98. Both authors cite Central Executive Committee files from GARF as their sources.

3 GARF, f. R-3316, op. 8, d. 222, 1. 1.

4 Gerald M. Easter, "Personal Networks and Postrevolutionary State Building: Soviet Russia Reexamined," World Politics, Vol. 48, No. 4 (Jul. 1996), 551578.

5 This study draws extensively on both archives as well as on the region's newspapers, and the materials relating to the Central Drafting Commission that are housed in the State Archive of the Russian Federation (GARF).

6 Robert Tucker, Stalin in Power: The Revolution from Above, 1928-1941 (New York: W. W. Norton and Company, 1992); Sarah Davies, Popular Opinion in Stalin's Russia: Terror, Propaganda and Dissent 1931-1941 (Cambridge: Cambridge University Press, 1997).

7 Ellen Wimberg, "Socialism, Democratism and Criticism: The Soviet Press and the National Discussion of the 1936 Draft Constitution," Soviet Studies, Vol. 44, No. 2 (1992), 313-332.

8 J. Arch Getty, "State and Society Under Stalin: Constitutions and Elections in the 1930s," Slavic Review, Vol. 50, No. 1 (Spring 1991), 18-35; Tretiakov, 
97-102; Sokolov, “Konstitutsiia 1936 goda i kul'turnoe nasledie stalinskogo sotsializma," 137-163.

9 Getty, "State and Society Under Stalin: Constitutions and Elections in the 1930s," 27.

10 Elena Aleksandrovna Shershneva defended a dissertation entitled "Sozdanie Konstitutsiia SSSR 1936 goda" on the process behind the formulation of the draft Constitution in 2011. While it does appear that she addresses the discussion of the Constitution, she does it from the perspective of the central leadership, focusing on the decrees that they issued. She uses only central archival material. An overview of her dissertation can be found at http://www.dissercat. com/content/sozdanie-konstitutsii-sssr-1936-goda accessed 8/20/2013.

11 Tucker, 352-353.

12 Tucker, 360.

13 For a discussion of "speaking Bolshevik," see Stephan Kotkin, Magnetic Mountain: Stalinism as a Civilization (Berkeley: University of California Press, 1995).

14 Lewis Siegelbaum and Andrei Sokolov, Stalinism as a Way of Life: A Narrative in Documents (New Haven: Yale University Press, 2000), 26.

15 Siegelbaum and Sokolov, 15-16.

16 Lewis Siegelbaum, Stakhanovism and the Politics of Productivity in the USSR, 1935-1941 (New York: Cambridge University Press, 1988).

17 Kotkin, 22.

18 The 25,000ers were workers and urban administrators who were dispatched in the early 1930s to play leadership roles in the collectivization process. Lynne Viola, The Best Sons of the Fatherland: Workers in the Vanguard of Soviet Collectivization (New York: Oxford University Press, 1987).

19 Siegelbaum, Stakanovism 8.

20 James Hughes, Stalinism in a Russian Province: A Study of Collectivization andDekulakization in Siberia (Basingstoke and London: Macmillan Press Ltd in association with the Centre for Russian and East European Studies, University of Birmingham, 1996), 208.

21 Hughes, 209.

22 Hughes, 211.

23 Charles Hier, "Party, Peasants and Power in a Russian District: the Winning of Peasant Support for Collectivization in Sychevka Raion 1928-1931," (unpublished dissertation, University of Pittsburgh, 2004).

24 Viatka is the pre-revolutionary name for the Kirov region.

25 Aaron Retish, Russia's Peasants in Revolution and Civil War: Citizenship, Identity and the Creation of the Soviet State 1914-1922 (New York : Cambridge University Press, 2008).

26 Larry Holmes, Grand Theater: Regional Governance in Stalin's Russia, 19311941 (Lanham, MD: Lexington Books, 2009). 


\section{Citizenship and a social contract The drafting of the 1936 Constitution}

Upon its adoption in December 1936, Soviet leaders hailed the new Constitution as the most democratic in the world. Western scholars and citizens have long scoffed at this claim, noting that the mass repression of 1937-1938 followed the adoption of the so-called Stalin Constitution. While the goal of this study is not to address these competing claims, the draft Constitution should be seen in the context of many leaders, including Stalin, feeling that the revolution had brought about radical changes in Soviet society, which required the re-conceptualization of certain groups' roles in Soviet society and the Constitution to be rewritten to reflect this new balance of power. Collectivization was a "fact," rapid industrialization was a "fact," and Soviet power was a "fact." As a result of these achievements, the 1934 Party Congress was referred to as the "Congress of Victors," and this victorious language is reflected in the press coverage surrounding the release of the draft Constitution two years later.

There are no documents in the archival record to contradict the Soviet leadership's public support for a more participatory Constitution or to indicate they viewed the Constitution and the subsequent discussion as mere propaganda, as some historians suggest. ${ }^{2}$ In fact, the archival records indicate that Stalin and other leaders were invested in the process, reading Western constitutions, meticulously editing the draft, and demanding accountability from regional officials for the collection of all the popular suggestions, which was in step with the Soviet Union's, and even Tsarist Russia's, larger history of "listening to the people."

While the reforms introduced in the Constitution may have been largely honored in the breach, as the mass repression of 1937 undid many of the promised changes, no one in the second half of 1936 could have anticipated such developments. As addressed more completely in Chapter 7, unexpected developments, such as unanticipated popular responses to the draft and the active participation of kulaks and other class enemies in the subsequent elections, precipitated the return to a restricted franchise and repressive measures. Other factors that influenced the Soviet State's return to repression include Stalin's paranoid personality, his distrust of the state and party elite, an unresponsive and obstinate regional bureaucracy, fear of potential 
threats from certain groups at home and abroad, and past success using repression to manage state-building efforts. ${ }^{4}$ Repression was a knee-jerk reaction to what Stalin and other Soviet leaders came to view as a hostile environment. This means that their sincerity in 1936 should not be called into question by the events of 1937, and in fact, their disillusionment with the incompleteness of the socialist victory and the rise of new challengers may help to explain the severity of the subsequent repression.

To grasp the reasons behind the Soviet leadership's opening up of mass participation in 1936, and the subsequent reaction in 1937, requires a brief overview of Soviet legal and constitutional theory to understand how top leaders conceived of democracy, the role of a constitution, and what responsibilities they envisioned for citizens. Soviet conceptualizations of democracy, viewed from the perspective of those who formulated them, reveal that, within their own understanding of politics and constitutionality, their intentions were both legitimate and earnest. It also reveals how such interpretations helped to frame, but not determine, the public discussion.

The party's central leadership had a very particular understanding of democracy and legality, which allowed for and even encouraged citizen participation. While Western scholars may see a contradiction between the tightly controlled one-party state based on the principles of democratic centralism and popular participation, no such contradiction existed in the minds of Soviet leaders. They viewed popular participation as essential for the development of the social and economic systems in the USSR, an interpretation that produced the participatory rhetoric preceding the discussion of the draft Constitution and provided the foundation for the central state leadership's attempts to guide and manage the discussion.

\section{The principles of constitutional theory in the USSR}

The new Constitution was the centerpiece of Stalinist legal reformation and state-building efforts. The Soviet state sought to increase social stability and political legitimacy in the wake of the vast political, social, and economic upheaval brought on by the Five-Year Plans. It did so through the redefinition of Soviet citizenship to include a much broader segment of the population, such as former kulaks and other former class enemies, who were disenfranchised in the two preceding constitutions, as well as expanding citizenship rights and access to state benefits. ${ }^{5}$ John Hazard argues that Soviet leaders in the Stalinist period used judicial decisions and legislation to solidify their position in power and to lay the foundation for a new pattern of social organization, while at the same time to codify and solidify the changes that had already been made. In the field of criminal law, this meant attempting to make officials behave rationally, i.e., to serve socialist institutions rather than their own interests, and by repressing enemies. ${ }^{6}$ Other historians, such as Peter Solomon, develop this idea further. He argues that the late 1930s saw a return to traditional legal order, replacing Nikolai Krylenko's ideas of 
"revolutionary legality," which relied on proletarian intuition, with professional cadres and systemized legal codices championed by Andrei Vyshinsky. ${ }^{7}$ Solomon believes that the promulgation of the new Constitution in 1936 was symbolic of this shift, as the discussion of the draft Constitution provided a forum for the promotion of the status and authority of law. ${ }^{8}$ This study of the discussion of the draft Constitution supports Solomon's assertion. However, Solomon views the 1936 Constitution as a farce, arguing that it never sought to promote popular participation but rather was designed to give the Soviet Union a veneer of respectability abroad and to enhance the authority and legitimacy of the Soviet government inside the country's borders. ${ }^{9}$ In contrast to Solomon, Stephen Kotkin asserts that "not only could the USSR under Stalin plausibly claim that it had developed the programs and practices of state-guaranteed social welfare to a greater extent than had previously been the case anywhere, but it could do so in a way that contrasted with the fascist reaction: by embracing fully the illustrious European heritage known as the Enlightenment." 10 This work asserts that Soviet leaders viewed participatory politics as a tool for socialist construction rather than an end in itself, but in formulating and promoting the Stalinist Constitution, Party and state leaders paid homage to the European roots of democracy.

The Constitutional Drafting Commission consulted multiple "bourgeois," i.e., Western constitutions, and ensconced many of the ideals of universal suffrage, popular participation, and the responsiveness of the state to its constituency in the draft. Karl Radek was charged with gathering the texts of foreign constitutions and appropriate laws and reviewing them along with Nikolai Bukharin (the editor of Izvestiia from 1934) and Lev Mekhlis (the editor of Pravda in 1936). ${ }^{11}$ The collected materials of the Constitutional Commission contain election laws from England, Belgium, Germany, Norway, Czechoslovakia, and Switzerland, copies of the "Declaration of the Rights of Man and of the Citizen" (1789), and various Western (bourgeois) constitutions. ${ }^{12}$ Although the archive does not contain notes on the discussion of these materials, when describing the proposed electoral system in 1937, Kalinin noted that the new Soviet system would resemble the French electoral system. ${ }^{13}$ And Molotov stated, "all the best [parts] of the democratic systems of other states we brought in and added to our Constitution to apply to the conditions of the Soviet state." ${ }^{14}$

In order to appreciate what aspects of European constitutional theory the Soviet leadership incorporated into the 1936 Stalinist Constitution, it is imperative to understand what role Bolsheviks believed that a constitution should play in Soviet society. Party and state leaders viewed the Constitution as the codification of the achievements of socialism, rather than a document that identified aspirational goals or guiding principles. In his November 1936 speech to the 8th Congress of Soviets, Stalin made it clear that the Constitution should not be confused with a program:

a program talks about what does not yet exist and that which must be obtained and won in the future, the Constitution on the other hand, 
must speak about what already exists, what has already been obtained and won now, in the present. ${ }^{15}$

Nikolai Krylenko, ${ }^{16}$ People's Commissar of Justice (July 20, 1936-September 15, 1937) and the Procurator General for the Russian Socialist Federated Soviet Republic (1929-1931), penned several works explaining why the new Constitution was drafted. ${ }^{17}$ Krylenko argued that the USSR had become a democracy of the majority and that the tightly regulated and limited dictatorship of the proletariat was no longer needed..$^{18}$ For many Soviet leaders like Krylenko, the 1936 Constitution represented a shift in the balance of power. In 1918, Bolsheviks and the support base for a Soviet state were seen as a beleaguered minority, but by 1936 many of the perceived enemies had been dealt with, leaving the Soviet leaders confident that they finally had majority support and could use this position of strength to further develop participatory politics in the USSR.

The Soviet leadership viewed popular participation as a powerful weapon against bureaucratism and corruption and were quick to solicit popular involvement to remedy these problems. ${ }^{19}$ To this end, Stalin advocated the expansion of the electoral franchise and multi-candidate elections, which were introduced in the draft 1936 Constitution and were to be applied to the elections to the Supreme Soviet in 1937. In his interview with Roy Howard on March 1, 1936, Stalin addressed the issue of open elections. ${ }^{20}$ While he dismissed the idea of multi-Party elections, he strongly supported the idea of multi-candidate elections. Stalin noted that under the new draft Constitution, social organizations of all varieties, not just the Communist Party, would have the right to nominate candidates for election. ${ }^{21}$ These contests, not between different parties but between different individuals, would allow the proletariat to effect change in the government and policy through mass participation. ${ }^{22}$ Stalin saw participation as an effective weapon against bureaucratic incompetence in the USSR:

I foresee very lively election campaigns. There are more than a few institutions in our country, which work badly. Cases occur when this or that local government body fails to satisfy certain of the multifarious and growing requirements of the toilers of town and country. Have you built a good school or not? Have you improved housing conditions? Are you a bureaucrat? Have you helped to make our labor more effective and our lives more cultured? Such will be the criteria by which millions of electors will measure the fitness of candidates, reject the unsuitable, expunge their names from candidates' lists, and promote and nominate the best. Yes, election campaigns will be very lively; they will be conducted around numerous, very acute problems, principally of a practical nature, of first class importance for the people. Our new electoral system will tighten up all institutions and organizations and compel them to improve their work. Universal, direct and secret suffrage in the U.S.S.R. will be a whip in the hands of the population against the organs of government, which work badly. ${ }^{23}$ 
What multi-candidate elections meant was that elections might provide an opportunity for citizens to reject local or regional political figures who did not represent popular-and Soviet-interests. Stalin and the Bolshevik Party had no intention of altering or endangering their Party or the concept of democratic centralism on which it was based. What they did seek to achieve by revising the Constitution and holding multi-candidate elections was to enhance the functionality, legitimacy of, and popular support for that Party and to remove "bureaucrats," in the pejorative sense of the word.

In the fall of 1936, in the face of numerous suggestions made during the popular discussion to re-impose limits on the voting franchise, Stalin defended his decision to grant universal suffrage and multi-candidate elections. In his speech to the 8th Congress of Soviets on the draft Constitution, Stalin stated that the Soviet state had deprived "dangerous elements" of voting rights during a time when they were waging open war against the people and undermining Soviet laws. Now that the exploiting class had been destroyed and Soviet power had been strengthened, it was time to introduce universal suffrage. He countered the argument that universal suffrage would allow enemy elements to worm their way into organs of power ${ }^{24}$ by replying that not all former kulaks and white-guardists were harmful to Soviet power, and if the people somewhere elect dangerous people, it would mean that agitational and propagandistic work was not carried out well. ${ }^{25}$

Molotov, too, focused on the idea of reasserting control over the regional and local organs of power by means of participatory elections. He noted that the new electoral system would secure the complete development of democracy and would help to improve the state apparatus through the expansion and renewal of leading soviet cadres and the elevation of working people to the Party organization. ${ }^{26}$ In addition to supplying new cadres with strong ties to the working people, "the new elections will shake up the weak and strike out at bureaucratism." ${ }^{27}$ Democracy was a tool to turn against incompetent and unresponsive regional and local bureaucratic organizations that had consistently frustrated central authorities. ${ }^{28}$

J. Arch Getty argues that Soviet leaders remained staunch supporters of multi-candidate elections through much of 1937, despite increasing resistance from regional and local Party leaders. He argues that the central leadership propagated a long campaign for multi-candidate elections and pushed regional leaders to make the appropriate preparations until October 1937, when, facing increased resistance and outright disobedience from regional Party apparatus, the Central Committee and Stalin abandoned the plans for multi-candidate elections. ${ }^{29}$ Though Soviet leaders primarily supported democratization as a tool for combating bureaucratism in the Party and state apparatus, they may also have genuinely embraced the fundamental notions of participation and, if Getty is correct, remained committed to the idea of multi-candidate elections until it became politically untenable. 


\section{Drafting the Constitution}

Although in popular parlance the 1936 Constitution is often referred to as Stalin's Constitution, Stalin's role in this study is episodic. He played a crucial role in articulating the official rationale for a new constitution, in convening the Drafting Commission, of which he was Chairman, and in editing the draft Constitution. His suggestions were usually, but not always, decisive. But as this study focuses on the popular discussion of the Constitution, Stalin's appearances are confined to these roles and few others. One of his more important roles was as an advocate for expanding those groups that qualified for enfranchisement, as mentioned above. He played an important role in bookending the discussion, first by contributing to the formulation of the draft and then by examining the outcome of the popular discussion and giving his support for the ratification of the little-changed draft Constitution in December 1936.

While Stalin played a leading role in formulating the Constitution, it was Molotov who announced the need to revise the 1924 Constitution at the 7th Congress of Soviets in February 1935, after which the Central Executive Committee proceeded to elect a 31 member Constitutional Commission. Despite being appointed in February, the commission's first meeting did not occur until July 7, 1935. Stalin chaired the initial session, which appointed 12 subcommissions to address the various facets of the Constitution. ${ }^{30}$ Stalin was Chairperson of the Commission, while Molotov and Kalinin served as vice chairpersons. Each of the subcommissions was chaired by a prominent political figure, all of whom were high-ranking Party members and many of whom had held state posts. ${ }^{31}$

Table 1.1 Composition of committee subcommissions ${ }^{32}$

\begin{tabular}{lll}
\hline Name of subcommission & Chair of subcommission & $\begin{array}{l}\text { Number of commission } \\
\text { members }\end{array}$ \\
\hline General questions & Stalin & 10 \\
Economics & Molotov & 17 \\
Finances & Chubar' $\dagger$ & 11 \\
Rights & Bukharin $\dagger$ & 9 \\
Electoral system & Radek $\dagger$ & 12 \\
Judicial organs & Vyshinsky & 9 \\
Central/local organs of & Akulov $\dagger$ & 10 \\
power & Zhdanov & \\
People's education & Kaganovich & 9 \\
Labor & Voroshilov & 13 \\
Defense & Litvinov & 11 \\
International affairs & Stalin and all subcommittee & 6 \\
Editing & chairmen & 11 \\
& & \\
\hline
\end{tabular}

$\dagger$ Four of the chairmen did not survive the mass repression: Chubar’ (d. 1939), Bukharin (d. 1938), Radek (d. 1939), and Akulov (d. 1937). 
During this initial session, the chairmen of the subcommittees were instructed to nominate their subcommittee members and to prepare drafts of their section of the Constitution in two months. The two-month deadline was not met, and the drafting work of the subcommissions continued into 1936. What had begun as changes to an existing constitution became a lengthy process, involving at least five drafts. Each subcommission produced its own partial draft, which the editorial subcommittee of Iakov Arkaidiovich Iakovlev, ${ }^{34}$ Aleksei Ivanovich Stetskii, ${ }^{35}$ and Boris Markovich Tal $^{36}$ wove together into a complete document by February 1936; a second version of this draft was formulated in April 1936. ${ }^{37}$ On April 17,1936, Stetskii, Iakovlev, and Tal' submitted a draft constitution to Stalin for his consideration. Stalin himself met with the editorial subcommission in his office on April 17, 18, 19, and 22, 1936, and personally revised the draft Constitution multiple times. On April 18, 19, and 22, the three drew up subsequent drafts, with most of Stalin's suggestions adopted wholesale. From there, the draft was presented to the whole Constitutional Commission, where even more changes were made, before being published for national discussion on June 12, 1936.

As this discussion of the Constitutional Commission's work suggests, the writing of the draft Constitution was a collective affair involving subcommissions, the editorial subcommittee, Stalin, and finally, the whole Commission. As the following discussion will make clear, the original draft itself underwent various revisions, some at the suggestion of commission members, some by the editing subcommission, and some by Stalin. Many earlier sources, such as Stephen Cohen's Bukharin and the Bolshevik Revolution: a political biography 1888-1938, credit Bukharin with writing the 1936 constitutional draft. ${ }^{38}$ The source for this claim comes from Boris Nikolaevsky's "Power and the Soviet elite: the letter of an old Bolshevik and other essays." ${ }^{39}$ However, upon examining the documents in the opis of the Constitutional Commission in the State Archive of the Russian Federation, ${ }^{40}$ the original complete draft appears to have been written by Iakovlev, Stetskii, and Tal' and heavily revised by Stalin himself. Bukharin's contributions were therefore probably limited to a draft of the section on rights, as he chaired that committee. Getty also concludes that Bukharin likely played a much less important role than previously ascribed to him, and that Stalin "clearly played a major role in the process and devoted considerable time to it." ${ }^{4}$ The available archival materials do not allow one to identify who, other than Stalin, proposed what aspects of the draft and why. But that should not sidetrack readers from a crucial aspect of the draft Constitution-it was the result of a collective effort by leading Party members and state officials who shared a common vision of the role and purpose of a constitution.

Examining the drafting process allows us to see a variety of opinions about the role of the state and offers a glimpse into the negotiations behind the formation of a central narrative about the role of the people in governance 
and the shaping of an ascribed citizen identity. Overall, the original draft produced by Tal', Iakovlev, and Stetskii focused on the creation of an encompassing program of sociocultural development, designed to create a modern Soviet citizen. As longstanding Bolsheviks, Iakovlev, Stetskii, and Tal' were committed to remaking society by changing social relations, gender roles, and obliterating bourgeois patterns of life. However, despite his radical economic policies of the 1930s, Stalin was a social conservative. He removed many aspects of the more radical social changes from the draft Constitution, ensuring the continuation of more traditional social roles and state-building efforts. Rather than examine the entire draft Constitution, this section will focus on the evolution of articles in the sections on social construction of the USSR, the Courts and Procuracy, elections and voting rights, and the rights and duties of citizens-each of which received considerable attention in the public discussion-in order to understand the master narrative that the Soviet leadership sought to project about its relationship to the people and the role of participation of the people in governance. ${ }^{42}$ Interested readers will find a copy of the Draft Constitution in the Appendix.

\section{Defining citizenship}

Citizenship rights define who has the right to participate in governance and who does not. In the first two Soviet constitutions, full citizenship rights were purposefully limited to workers, peasants, and certain other laboring people. Many members of the former exploiting classes were disenfranchised and excluded from governance and, in some cases, from state programs like education. With the announcement of the victory of socialism and the destruction of exploiting classes, who was entitled to full citizenship rights in the USSR had to be redefined. By examining the changes in the various drafts, we can appreciate the process of constructing citizenship identities in the USSR. We can also analyze the internal Party and state dialogue as various leaders proposed differing definitions of citizenship and citizenship rights in the drafts of the Constitution, where class, race and nationality, gender, and participation in electoral franchise helped to define citizenship.

Because of the Marxist nature of the Soviet state, class was the defining factor in classifying citizenship. The first section of the draft Constitution demarcated the class make-up of the USSR and clarified in which classes sovereignty was vested. The first article of Stetskii, Tal', and Iakovlev's original draft defined the USSR as a socialist government of free laborers (трудя щихся) of the city and country, and stated that all power in the USSR rests with the laborers in the persons of the Soviets of Laborers' Deputies. ${ }^{43}$ Stalin heavily revised this article, changing it to "the USSR is a socialist state of workers (рабочих) and peasants (крестьян)" 44 and took the second half of the original Article 1 and made it a separate article. Stalin's description of the organs of power in the USSR became Article 2: "The political basis of the USSR is composed of the Soviets of Workers' and Peasants' Deputies/ 
Soviets of Laborers' Deputies ${ }^{45}$ which developed and became stronger as a result of the overthrow of power of the landlords and capitalists." ${ }^{46}$ Stalin emphasized the existence of two official classes, workers and peasants, by changing the name of the Soviets in the original draft. He also added a completely new Article 3 to Stetskii, Tal', and Iakovlev's April 17th draft, recommending: "All power in the USSR resides in the laborers of the city and countryside in the persons of the Soviet of Laborers' Deputies."

These first three articles acknowledged the concept of popular sovereignty in that all power was vested in and arose from the people, while also noting the role that the victory over the exploiting classes had in shaping the state's broadening conception of its constituency. However, Stalin's decision to define the USSR as a state of "Workers and Peasants" rather than "laborers" would have real far-reaching consequences for the people of the USSR. While the Russian word "laborers" (трудящихся) refers to all laboring people without differentiation, the use of the words "workers and peasants" implies a strong separation of the two. The rhetorical separation of workers and peasants in the draft Constitution both created and implied real inequality between the two groups and perhaps acknowledged the incompleteness of the transformation in the countryside. In his speech at the 7th Congress of Soviets in 1935, Molotov stated: "Soviet Democracy provides for the participation of the peasantry, with guidance, in the task of administering the new government." ${ }^{47}$ Molotov essentially implied that the peasantry was still not developed enough to be trusted and still needed "guidance" from the more socially conscious working class. Subsequent amendments made to the section on citizens' rights and duties demonstrated that Stalin did not regard peasants as full citizens with all the rights and privileges of the working class. ${ }^{48}$ This was to be of profound importance, given that other articles specified workers received more benefits from the state than the peasants. This unequal distribution of rights, despite guarantees of equality, would be strongly contested during the public discussion of the draft.

In contrast with Stalin's definition of a "classless" society composed of two classes with different rights, Stetskii, Tal', and Iakovlev had proposed a different, more egalitarian, interpretation of class in the USSR. Article 10 of their April 17 draft stated:

In the USSR the division between classes has been annihilated. In the USSR there is no exploitation of people by other people, no parasitical classes living off the work of the workers and peasants. Soviet society is comprised of free toilers of the city and countryside-the workers, peasants and intelligentsia. All of them are builders of socialism with equal rights. ${ }^{49}$

This conceptualization of classlessness in the USSR would have made the collective farmers equal to workers, because it denied that any important 
differences between them existed. However, Stalin struck this article from the draft completely on April 17 in favor of his concept of a strictly divided working class and peasantry. In his speech on the Constitution at the 8th Congress of Soviets in November 1936, Stalin defended his word choice, stating that it is well known that the Soviet Union has two classes, workers and peasants, and that only this phraseology represents the "true" social makeup of the USSR. ${ }^{50}$

While class remained the most important factor for determining Soviet citizenship, the Commission's members recognized that race, nationality, and gender limited franchise in most democracies. They responded by promising equal rights for all races (расы) and nationalities, and both sexes. Gender and racial equality were incorporated in the first two Soviet constitutions as part of Lenin's strategy to minimize their importance relative to class. The Soviet leadership's stance on racial equality had not changed much by 1936. Iakovlev, Tal', and Stetskii's draft article on race stated that all citizens of the USSR have equal rights, regardless of nationality or race. It guaranteed aid to help disadvantaged national minorities and guaranteed their rights as national minorities. ${ }^{51}$ Other than some minor changes in wording, this article was not changed.

Women's rights had long been a key issue for socialists. The first Soviet Constitution, written in 1918, granted women equality and the right to vote. However, the Bolsheviks were not satisfied with merely declaring women equal. They also sought to give them the tools to realize that equality and to liberate them from domestic burdens so that they could enter the workforce. Therefore, Stetskii, Iakovlev, and Tal' proposed an article on women's rights that featured a list of state programs designed to help women realize their equality. The article granted

every woman equal rights with men to work, equal pay for work equivalent to its quality and quantity, equal opportunities for elementary, middle and higher education, in the law about marriage stipulating the safeguarding of the interests of mother and child, granting pregnant women leave with pay, organizing public catering, kindergartens and nurseries, concern about construction of the family on the basis of equality between men and women. ${ }^{52}$

Stalin made only minor changes to this article on April 19, but on the 22nd he presented a version that removed some of the specific privileges and protections that Stetskii, Tal', and Iakovlev's version provided to women. Stalin's new version did not include equal pay for equal work, or the promotion of equal gender roles within the family. ${ }^{53}$ The full session of the Constitutional Commission further altered this article, adding that women were equal in state life, as well as economic, cultural, and sociopolitical life. It reinstated the stipulation about equal pay and replaced the state guarantee of social dining with a promise of an expanded network of birthing 
houses, which was more in line with the state's new emphasis on the role of women as mothers. ${ }^{54}$

The final aspect of citizenship in the USSR was connected with who was able to vote and be elected by the Soviets. In contrast with the earlier 1918 and 1924 Constitutions, there were no class restrictions on voting in the new draft Constitution because the Soviet leadership felt confident that former class enemies had been successfully integrated or otherwise neutralized and the punitive restrictions could be lifted. Tal', Stetskii, and Iakovlev's draft section on election law consisted of two articles. One stated that "Elections to all Soviets of laborers are Universal: every citizen, who in the election year has reached 18 years of age has the right to participate in elections and be elected, with the exception of under-aged people and those stripped by the courts of voting rights." 55 The other article guaranteed equal voting rights to women and racial minorities. ${ }^{56}$ The wording of this article changed very little, though Stalin broke down the second article about protection for women and minorities further, creating two separate articles, one dealing with minority rights and one dealing with women's rights.

Central authorities and media outlets emphasized the expansiveness of citizenship in the USSR. However, the rhetorical changes that Stalin made effectively limited the rights of collective farmers and removed some of the earlier guarantees of material aid to women. Citizens addressed both of these shortcomings during the public discussion. And while the expansion of the franchise was heralded as a step towards greater participation by the center, many people challenged it.

\section{The rights of citizens}

In assigning the rights and duties of citizens, there appears to have been a great deal of discussion amongst the four men who produced the text of the draft Constitution. When focusing on citizens' rights, Stetskii, Tal', and Iakovlev typically presented detailed plans for a symbiotic relationship between the state and citizens that guaranteed a wide array of rights and services that would further enhance socialist state-building efforts. Stalin's edits often simplified or even removed whole articles that Stetskii, Tal', and Iakovlev had proposed, though on some occasions the deleted sections were later reinserted into the text by the whole Commission. These rights were so carefully crafted because they were not simply propaganda but real programs the state sought to implement for its citizens. For the most part, these goals were met, with the state providing social, educational, and medical benefits to its citizens, reacting harshly to the suppression of criticism by local leaders and protecting personal property in the face of earlier, overly enthusiastic collectivization efforts. Some of Stetskii, Tal', and Iakovlev's articles were probably more suited for legislative initiative, and indeed some of the content that Stalin removed from the draft reappeared in later legislation. Since no explanation for the changes was given, one can only speculate 
as to why changes were made. However, viewed together the changes made to the articles of the draft Constitution tell the story of the creation of a central narrative about citizens' rights, the popular participation in government, the privileges granted by the state, and the duties that citizens had to fulfill in return for these privileges.

Participation in governance is one of the fundamental factors in citizenship and a basic right of citizens. In this vein, the proposed second article from Tal', Iakovlev, and Stetskii's draft section on citizens' rights sought to create a participatory society to help the masses bring the state apparatus back under control. It reads:

Citizens of the USSR have equal rights to participate in the administration of the state. The USSR guarantees this right, engaging laborers though the soviets, in the administration of the state, organizing on the basis of collective farm charters, the participation of all collective farmers in the administration of large scale social production, engaging laborers from state factories, collective farms and other enterprises to actively participate in the administration of the economy, promoting their unification and organization, supporting professional unions, the Komsomol $^{57}$ and other social organizations in their work to unify the laborers and struggle with the bureaucratic perversion of soviet and economic organs..$^{58}$

This proposed article provided for the direct, albeit rather structured participation of citizens in administering aspects of the state. It also supported the initiative to rid the Soviet state apparatus of "bureaucratic perversion." This draft article makes clear the nature and limits of the commission's view of a participatory society. The article extended the opportunities for participation beyond the Communist Party and the Komsomol to trade unions and a host of other social organizations, which while limited to fighting bureaucratism, may have provided latitude for effecting real change on the state apparatus. ${ }^{59}$

Stalin removed this article from the draft Constitution on April 19. However, on April 22 he added a different article allowing for the participation of approved organizations in the process of governance. Stalin's proposed article was, in turn, revised by the full Constitutional Commission. Stalin's version read:

In accordance with the interests of the laborers in developing spontaneous organizations and the political activities of the masses, the right to unite in voluntary organizations and societies is provided to the citizens of the USSR: professional unions, cooperative associations, unions of youth, sporting and defense organizations, cultural, technical and scientific societies. The most active and conscious people from amongst the workers and general laborers will unite in the Communist Party, 
becoming the first detachment of laborers in the fight for the victory of communism and the leading force of all laborers, organizations in the USSR. ${ }^{60}$

The Constitutional Commission edited the last section of Stalin's proposed article so that the Party would strive for the "strengthening and development of socialist construction and is presented as the leading nucleus (ядро) of all organizations of laborers, society and the state." ${ }^{11}$ Additionally, another article allowed for civic organizations to nominate candidates in elections, providing some chances for the contested elections that Stalin had envisioned. ${ }^{62}$

Stalin's version of participatory rights was more limited in scope than was that of Stetskii, Tal', and Iakovlev. Robert Tucker notes that, in keeping with practices established in the 1918 RSFSR Constitution, these changes effectively brought all state and civil organizations under Party oversight, as it gave them the right to control institutions' administration and limited the choice of candidates whom they could nominate in the upcoming elections. ${ }^{63}$ As a result, the focus of the subsequent propaganda campaign during the discussion of the draft Constitution was on increasing citizen participation in established organizations, often with the expressed purpose of combatting bureaucratism.

Another aspect from the 1918 and the 1924 Constitutions that was carried over into the draft 1936 Constitution was the provision of the material conditions for the realizations of citizens' rights. Like the right to participate in governance, however, these rights were often tailored to protect those who conformed to the state's goals. For example, the USSR had a curious relationship with the freedom of speech, press, and assembly. On one hand, the state encouraged citizens to engage in criticism of the state and Party apparatus as a control mechanism to bring the often-contentious regional and local organs to heel. ${ }^{64}$ On the other hand, the formation of contending parties or even factions within the Communist Party was forbidden and had dire consequences. Stetskii, Iakovlev, and Tal's draft recognized this apparent contradiction, couching these freedoms of expression in the context of promoting the final victory of socialism, stating, "Citizens of the USSR are provided (with the aim of the struggle for the final victory of socialism) the freedom of expressing their opinion, the freedom of the press, free meetings, demonstrations and organization." ${ }^{65}$ They also incorporated the means to realize these rights

by granting [to the people] all that is applicable for accommodating people's meetings, all typographic establishments at the disposal of the laborers and their social organizations, paper for the printing of newspapers, books, etc., and other industrial press, establishing their free distribution to the whole country, [as well as] organizing the construction of new societal buildings. ${ }^{66}$ 
Soviet leaders viewed this promised accessibility as an important distinction between socialist and bourgeois constitutions.

Because of the nature of the Soviet state's relationship with these rights, this article underwent multiple and complex editing sessions. On April 19, Stalin separated Tal', Iakovlev, and Stetskii's article on the right to free speech, press, and association into several articles, while simultaneously merging the freedom of expression with Stetskii, Tal', and Iakovlev's article on citizens' rights to criticism and self-criticism. The initial article presented the right to criticize as invaluable in the "fight with the bureaucratic perversions in the state apparatus and in the elimination of hindrances (преп ятствий) in socialist construction." ${ }^{67}$ Stetskii, Tal', and Iakovlev valued the freedom to criticize officials to such an extent that they included measures to prevent local officials from stifling criticism, "guaranteeing this right by sternly punishing and looking into the faces of all the guilty, in defense of anybody persecuted for criticism and self-criticism." ${ }^{68}$ Stetskii, Iakovlev, and Tal' also included a separate clause allowing citizens to hold such officials accountable by giving citizens "the right to demand any official figure be prosecuted for breaking this law." ${ }^{69}$ Stalin's version shared characteristics of the parent articles, combining provisions for the realization of the right of free speech (meeting places, etc.) with the right to freely criticize the state and officials. ${ }^{70} \mathrm{He}$ also drafted articles providing for the freedom of assembly and the freedom of organization. ${ }^{71}$ The right to criticize local officials fit neatly with Stalin's and the Soviet leadership's goal of turning participatory policies into a weapon against elements within the bureaucracy. However, Stalin may have considered such specific goals inappropriate for a constitution. On April 22, he again condensed these articles into one article, with the caveat that these rights (free speech, free press, freedom to have meetings, and freedom to demonstrate) were guaranteed "in accordance with the interests of the laborers and the goal of strengthening socialist construction." 72 This final draft did not contain any specific mention of the right to criticize state officials, but it may have been implied as part of strengthening socialist construction. It also limited the use of the rights of free speech, press, and assembly to only those activities deemed to be in the interests of the masses or the state, effectively curtailing other forms of opposition. While such a caveat had existed from the first draft of this article, where these rights were enumerated in the context of struggling for the final victory of socialism, Stalin's language made it clearer that opposition to state goals was not acceptable, even if opposition to local leaders and bureaucrats was encouraged.

Supplementing citizens' rights to free speech was an article on citizens' rights to engage in propagandistic activities. Iakovlev, Tal', and Stetskii's original article stated:

A citizen of the USSR is granted the freedom of propaganda of a materialistic worldview. To citizens, not having freed themselves from 
religious prejudice, the USSR gives the freedom of departure from their religious cults, but the teaching of any religious studies in schools is not permitted. ${ }^{73}$

Stalin reworked this article to focus more on a separation of church and state and the suppression of religion:

With the goal of ensuring real freedom of conscience for the laborers, the church is separated from the state and the schools from the church. Freedom of materialistic worldview propaganda and departure from religious cults is recognized for all laborers. ${ }^{74}$

On April 22, Stalin removed the words "materialistic worldview propaganda" and later the full Constitutional Commission added the freedom to engage in anti-religious propaganda. ${ }^{75}$ Like the right to free speech, the right to engage in propaganda could only be used in the interests of the state, i.e., for anti-religious purposes, even though during the discussion many people interpreted this as a right to also engage in religious agitation, much to the state's chagrin.

In addition to providing more traditional rights for their citizens, members of the Soviet leadership set about providing guarantees of government sponsored social services, such as education, paid vacations, and financial and material aid. Tal', Iakovlev, and Stetskii's draft provided an extensive program of education for every citizen of the USSR. They introduced universal mandatory elementary education and made schooling prior to the university-level free, created seven-year instruction in the native languages of the peoples of the USSR, as well as "organizing productive-technical and agricultural instruction and political enlightenment for adults and youth in factories, state farms, machine tractor stations and on collective farms" designed to promote the "systematic raising of the level of workers in engineering-technical and agricultural work." 76 To ensure that education was accessible for all citizens, Stetskii, Tal', and Iakovlev's draft provided for the financial support of high school students (обучающихся) at the state's expense. But their draft went above and beyond the confines of traditional education. They mandated "bringing books, newspapers, film, theater, sports, schools for adults serving in the Red Army, political and general cultural instruction facilitating the self-cultivation of laborers in all spheres in their own creative work, within the reach of the masses of laborers." 77 This focus on creating both an educated populace and cultured modern Soviet citizens had long roots in Bolshevik policy and thought. ${ }^{78}$ For example, the Proletkult movement, which pushed for the creation of a genuine proletarian culture, dated back to 1917. During the Civil War period, Proletkult had flourishing theater workshops, studios, literary circles, and adult education classes under its administration. ${ }^{79}$ Although the Proletkult movement faded during the New Economic Policy (NEP), the Bolsheviks never abandoned 
the idea of cultivating proletarian consciousness. Continuing such efforts, Stetskii, Tal', and Iakovlev's draft provided a comprehensive program of not just education but of "enlightenment."

In his April 19 edit, Stalin removed the focus on enlightenment from this article. His new version read:

Citizens of the USSR have the equal right to education. This right is guaranteed by the existence of universal compulsory elementary education, free education up to higher educational institutions, and state aid for instruction in schools in native languages. This right is also secured by the organization in factories, state farms, machine tractor stations and on collective farms of industrial-technical and agricultural instruction for adults and youth, and the systematic raising of workers and collective farmers to the level of workers of engineering-technical and agricultural work. ${ }^{80}$

Then on April 22, Stalin decided to make the technical instruction in factories and farms explicitly free, conceivably to encourage the rapid development of skilled workers in these important economic sectors. ${ }^{81}$ At the June meeting of the entire Constitutional Commission, a clause providing "systematic state stipends to an overwhelming majority of students in higher schools" was added..$^{82}$ While this amendment provided additional state support for education, it failed to live up to the all-encompassing program of "enlightenment" that Stetskii, Tal', and Iakovlev had initially envisioned.

The focus on enlightenment dominated another of the draft articles in Tal', Iakovlev, and Stetskii's version of the Constitution. Article 6 focused on developing Soviet youth, stating:

Youth in the USSR have the right to material security and cultural development. The USSR guarantees the realization of this right for all young men and women of the USSR, limiting the work day to four hours for teenagers under 16, with pay as if for a full work day, combining the work of teenagers with their instruction in schools for factory apprenticeship, protecting the health of teenagers and organizing treatment for the ill in rest houses and sanatoria, abolishing the exploitation of children and teenagers as landless laborers, establishing ample opportunity for independent work for peasant youth, and raising their qualifications with exposure to city culture..$^{83}$

In his comments on April 19, Stalin left most of this article intact, changing only the section that applied to rural youth. Rather than being preoccupied with their cultural level, Stalin changed the article to read that peasant youth now "have the ability to become qualified, cultured operators of large-scale agricultural machinery." ${ }^{44}$ This entire article was removed from the April 22 draft, but portions of it reemerged later as part of the Labor Code. 
Despite not being part of the final draft of the Constitution, this article demonstrated that some Soviet leaders were not just creating a legal code but trying to create a new, modern, and educated citizenry.

Tal, Iakovlev, and Stetskii's Article 7 in the citizens' rights section also emphasized, albeit implicitly, raising the cultural level of citizens by allocating leisure time.

Citizens of the USSR have the right to rest, to comprehensive physical and cultural development. The USSR guarantees every citizen the use of this right, shortening the working day, establishing yearly vacations for laborers (трудящимся), providing free medical aid for laborers, rendering state aid for the construction of sanatoriia, rest houses, and sports stadiums. ${ }^{85}$

Stalin revised this article to the point that its meaning changed dramatically. His version from April 19 read: "Citizens of the USSR have the right to rest. This right is guaranteed by the shortening of the working day, the establishment of yearly vacations for workers and service workers [emphasis added] with retention of pay, and the construction of sanatoriia, rest houses and clubs." ${ }^{86}$ While Stalin again diminished the focus on an encompassing program of cultural and physical development, the most important change Stalin made was to change the word "laborers" (трудящимся) to workers and service workers, which thereby effectively excluded collective farmers from yearly vacations. On April 22, after further deliberation with Stetskii, Tal', and Iakovlev, Stalin made still more changes to this article by adding the qualification: "the right to rest is secured by the shortening of the working day for the majority of workers [emphasis added] to 7 hours." ${ }^{87}$ These changes further disenfranchised the collective farmers by only limiting the working day for workers, though peasants still theoretically had access to rest houses. However, the funding and construction of these sanatoria, rest houses, and clubs was no longer guaranteed. This version only promised that these institutions be open for use, not that the state should fund or build more. This discrimination against the collective farmers did not go unnoticed during the discussion of the draft Constitution and raised serious questions about the equality of Soviet citizens.

While Stalin seemed to have the final say on most of the changes to the first draft of the Constitution, the editorial process surrounding the article on state social security benefits seems to have relied more on compromise between Iakovlev, Tal', and Stetskii on one hand, and Stalin on the other. Like the right to rest, the original version was egalitarian, stating:

Citizens of the USSR have the right to security in old age, and also to material aid from the state in cases of the loss of health or working ability. This right is guaranteed by the USSR through the organization of state benefits and social security at the state's expense and on the basis of the model of the agricultural artely charter. ${ }^{88}$ 
On April 19, Stalin removed the phrase “at the state's expense" (на счет г осударства) from the clause about social security and added that laborers can have access to resorts and sanatoria. ${ }^{89}$ However, on April 22, he reinserted the phrase "at the state's expense" and specified that citizens have the right to material aid. ${ }^{90}$ Collective farmers were not specifically excluded. However, as discussed below, citizens noted that the draft Constitution only provided for parts of the population to realize these rights and the expansion of access to governmental services would make up the bulk of citizens' comments.

Property rights were another gray area for the Soviet state. On one hand, the leadership hailed the collectivization of agriculture and state ownership of industry as markers of socialist victory, and they denounced bourgeois constitutions that were too focused on property rights for the elite. On the other hand, they sought to provide for the continuation of individual smallholdings and craftsmen and to protect personal property from state seizures. Originally, Tal', Iakovlev, and Stetskii's article on property rights was rather general, stating:

Citizens of the USSR have the right to personal property. The USSR secures this right, safeguarding by law personal property of laborers of the city and countryside. No one has the right in the USSR to encroach upon the personal property of citizens, unless stated otherwise, like the decision of the courts and in cases especially provided for by the law. ${ }^{91}$

Stalin's changes to this article on April 19 were minor. But on April 22, he removed this article from the section on citizens' rights and duties entirely, and he added an article on personal property to the first part of the Constitution on the construction of the state. That article states: "The personal property of citizens, in their earned income or savings, in the objects of household economy and utensils, together with the objects of personal consumption and comforts, are safeguarded by law."92 The full Constitutional Commission added the protection of the home to the list of protected personal property. ${ }^{93}$ The revisions made to this article indicated that property was not thought of so much as a citizen's right, but rather its safeguarding was a legal function of the state.

In addition to property laws protecting the personal effects of all citizens, the first draft of the Constitution had a specific article designed to define collective property and collective duties to the state. The article began by defining collective farms as "enterprises founded by collective farmers, voluntarily collectivizing their means of production and conducting their economic activity on land belonging to the state, and which conduct economic activity in accordance with their charter on the basis of a plan and under the leadership of Soviet state organs."94 Stetskii, Iakovlev, and Tal' succinctly defined collective farms, but also implied that they have a symbiotic relationship with the state, noting that "collective farms bear state 
obligations, established by law." 95 But Stetstkii, Tal', and Iakovlev did not conceive of this as a unilateral relationship. According to their draft article, the state also bore certain responsibilities to the collective farmers. The Soviet state, "through our machine tractor stations, [is responsible for providing] tractors, combines, and other modern agricultural machines to collective farmers for working the land and harvesting." 96

In addition to promising collective farmers access to modern agricultural equipment, this article also sought to codify the difference between collective farm property and the collective farmers' personal property, noting that,

together with the social property of the collective farm, every collective farm household has for personal use a garden plot, the dimensions of which are specified in the charter of the agricultural artel', a milk producing cow, and petty agricultural stock ${ }^{97}$

This article guaranteed the right to a household economy for collective farmers, though the subordination of personal property to collective property was in line with laws protecting state property. As Iakovlev, Stetskii, and Tal' drafted this article, it implied mutual responsibility for the success of Soviet agriculture as well as the creation of a private economic sphere within what was an otherwise very collectivized economy.

In his April 18 revision of this article, Stalin removed the description of collective farms and their cooperative relationship with the state. Instead he chose to specify what constitutes collective farm property: "Social enterprises on collective farm and cooperative organizations, with their living and inanimate stock, used in collective farm and cooperative organization production, equally with their communal buildings, are property of the collective farms and cooperative organizations." "98 Four days later, he revised the section on collective farmers' personal property, changing the article so that every household could have "a small [emphasis added] garden plot and personal property for subsidiary economic activity on the garden plot, a milk cow, fowl and petty agricultural stock as specified in agreement with the charter of the artel'." 99 The Constitutional Commission added the guarantee of a house to the list of collective farmers' property. ${ }^{100}$ Stalin's changes removed the mutual responsibility of the state and collective farmers for agricultural production and made it clear, through the specificity of protected property, that any activity taking place on the collective farmers' garden plots was to be secondary to the work on the collective farm. His revisions thereby served to strengthen the principle of the supremacy of collective property in the USSR.

However, not all citizens' protections had such limitations. In the midthirties, Andrey Vyshinsky and Stalin both promoted a return to codified legal statutes and legal order in the face of the chaos caused by collectivization, rapid industrialization, and other official campaigns. This shift in Soviet legal thought was codified in habeas corpus-style protections in the 
draft Constitution. The original version of habeas corpus that was included in Iakovlev, Tal', and Stetskii's draft established basic protections:

Citizens of the USSR are equal before the law. No one may be freed from prosecution, who is liable by law. No one may be subject to arrest, except by decision of the court or with the sanctions of the procurator. ${ }^{101}$

On April 19, Stalin rewrote the article to include citizens' rights to hold public figures accountable. His article stated: "Citizens of the USSR are equal before the law. Citizens of the USSR have the right to demand any public official be prosecuted for breaking the law. No one may be placed under arrest without a court order or sanction of the procurator. No one may be freed from prosecution, who is liable by law." ${ }^{102}$ This once again illustrates Stalin's distrust of bureaucrats and desire to use popular participation as a weapon against corruption. However, Stalin further revised the article on April 22, removing the section about public officials. The new article was streamlined: "Citizens of the USSR are guaranteed the inviolability of their person. No one may be placed under arrest without a court order or with the sanction of the procurator." 103

The inviolability of the person was complemented by the inviolability of the home which appeared in Tal', Iakovlev, and Stetskii's original draft ${ }^{104}$ and to which Stalin later added a guarantee of privacy in written communication. ${ }^{105}$ While these new habeas corpus laws sought to protect citizens from the extra-legal arrests of the early thirties, citizens widely and almost unanimously rejected them, because people viewed them as a hindrance to restoring order in the countryside. The reasons for this seemingly puzzling stance are examined in Chapter 5.

\section{The duties of citizens}

The leadership of the USSR sought to guarantee social services to Soviet citizens that were designed to enrich their lives and create better citizens, and to protect citizens from state encroachment into certain spheres of their life. However, this was a reciprocal relationship. If the state had obligations to its citizens, then citizens had obligations to the state as well. Tal', Iakovlev, and Stetskii's draft contained several articles enumerating the duties of citizens, including defending socialist property and the Constitution, raising children properly, and defending the USSR. Most of these articles underwent only minimal edits, as they reflect the state's need to defend itself from various enemies and to strengthen socialism.

As the fundamental law of the USSR, the Constitution played an important role in state building. Therefore, citizens were responsible for safeguarding its main tenets. Tal', Iakovlev, and Stetskii drafted an article requiring

[e]very citizen of the USSR [to] observe the Constitution of the USSR, executing its fundamental law and, also, decisions and instructions, 
guard daily the iron discipline of labor, be honestly concerned with labor and social duty, [and] respect the maxims of socialist society. ${ }^{106}$

Stalin made only minor changes to this article, removing the words "executing its fundamental law" and the word "iron," 107 indicating consensus in the Soviet leadership that citizens must obey the laws of the USSR, in particular labor discipline, which helped to promote the construction of a socialist society.

As part of their efforts to strengthen socialist values of the USSR, Iakovlev, Tal', and Stetskii suggested that citizens had the responsibility of rearing their children in a socialist manner, stating: "Every citizen of the USSR must raise their children to be physically healthy and culturally committed to their motherland, and to hate the laborers' enemies." 108 While this suggestion may appear comical out of context, it demonstrated the commitment to an overall program of sociocultural development that Iakovlev, Tal', and Stetskii promoted in their original draft Constitution. Stalin removed this article from the Constitution on April 22, demonstrating his commitment to either a less radical socialist redevelopment of life or his realization that such issues were more effectively dealt with through legislation.

Tal, Iakovlev, and Stetskii also proposed more conventional ways to make citizens commit to the state and safeguard socialist gains. Their draft contained an article on the defense of socialist property, which stated:

Every citizen of the USSR must defend, take care of and increase social property, the sacred Constitution and the inviolable base of Soviet construction as the source of wealth and power of the motherland, as the source of a prosperous and cultural life for all laborers. People encroaching on socialist property are considered enemies of the people. ${ }^{109}$

Stalin removed the word "defend" from this article, but made no other changes to it. ${ }^{110}$ The Constitutional Commission removed the part about taking care of the Constitution, focusing this article solely on social property. ${ }^{111}$ The emphasis on the sacredness of socialist property reinforced a commitment to the socialist economic structure and to punishing those who would violate it.

Military service was the ultimate defense of the Soviet state from enemies, and the language of the draft articles on military service reflected that fact. Tal', Iakovlev, and Stetskii's draft stated:

[T] he defense of the motherland is the sacred duty of every citizen of the USSR. Military service is the honorable right and duty of every citizen of the USSR. The betrayal of the motherland, that is for citizens to commit acts to the detriment of the military might of the USSR, its state independence or the inviolability of its territory, is to be punished with all harshness of the law, as the most terrible, abominable crime." 112 
Stalin made some changes to this article, changing the word motherland to fatherland, adding that breaking the military oath or going over to the side of the enemy and spying were considered treasonous acts, and removing the parts about territorial sovereignty. ${ }^{113}$ But he left the essence of the article, the "sacred duty" to defend the USSR, intact. In addition, he created a whole new article to address the role of a citizen army. Initially it read, "military service is the honorable right and duty of every citizen in the USSR. The Workers' and Peasants' Red Army is built on the principle of universal military duty." 114 Later the language was revised so the article read, "Universal military service is a duty (повинность) required by law, and military service in the Worker and Peasants' Red Army is presented as an honorable duty of the citizens of the USSR." 115 This focus on military service reflected both the revolutionary concept of citizen soldiers that goes back to the French Revolution and the increased military preparedness in the USSR in the face of the rise of fascism in Europe and uncertainty in the Far East. Service in the military as part of a citizen's duties to the state was a topic of great debate during the discussion of the draft Constitution. Part of the debate focused on whether women, as equal citizens, should have to serve in the army. Others focused on the idea of military service as an obligation (повин ность) rather than an honor.

The drafting of the new Constitution highlights the state's attempt to create a new social contract with its citizens and what it expected from them in return. This framework set the context for the public discussion, which focused on the redefinition of citizens, and citizenship rights, including the re-enfranchisement of former priests and kulaks (prosperous peasants). It further illustrates those aspects of the Constitution, such as increased material benefits, that the central leadership sought to highlight, and how it hoped that the discussion of the draft Constitution would be instrumental in generating enthusiasm for state-building projects.

\section{Notes}

1 Stephen Kotkin talks about the development and internalization of this socialist culture in Magnetic Mountain: Stalinism as a Civilization (Berkeley: University of California Press, 1995).

2 Sarah Davies, Popular Opinion in Stalin's Russia: Terror, Propaganda and Dissent 1931-1941 (Cambridge: Cambridge University Press, 1997); Robert Tucker, Stalin in Power: The Revolution from Above, 1928-1941 (New York: W. W. Norton and Company, 1992).

3 Larry Holmes addresses this idea in Chapter 4 of Grand Theater: Regional Governance in Stalin's Russia, 1931-1941 (Lanham, MD: Lexington Books, 2009), as does Sheila Fitzpatrick in "How the Mice Buried the Cat: Scenes from the Great Purges of 1937 in the Russian Provinces," Russian Review, Vol. 52, No. 3 (Jul. 1993), 299-320; "Signals from Below: Soviet Letters of Denunciation of the 1930s," The Journal of Modern History, Vol. 68, No. 4; Practices of Denunciation in Modern European History, 1789-1989 (Dec. 1996). 
4 Oleg Khlevniuk, “Top Down vs. Bottom-Up: Regarding the Potential of Contemporary 'Revisionism," Cahiers du monde russe, 56/4 2015), Online since 01 October 2015, Connection on 01 October 2016. URL: http:// monderusse.revues.org/8253; J. Arch Getty, "Pre-election Fever: the Origins of the 1937 Mass Operations" in James Harris, ed., Anatomy of Terror: Political Violence under Lenin and Stalin (Oxford: Oxford University Press, 2013); J. Arch Getty, “'Excesses Are Not Permitted': Mass Terror and Stalinist Governance in the Late 1930s,” Russian Review, Vol. 61, No. 1 (Jan. 2002), 113-138; J. Arch Getty and Oleg Naumov, The Road to Terror: Stalin and the Self-Destruction of the Bolsheviks, 1932-1939 (New Haven, Conn.: Yale University Press, 2010); Shearer, David, Policing Stalin's Socialism: Repression and Social Order in the Soviet Union, 1924 -1953 (New Haven: Yale University Press, 2009).

5 David Shearer, Policing Stalin's Socialism: Repression and Social Order in the Soviet Union, 1924-1953 (New Haven: Yale University Press, 2009); Paul Hagenloh, Stalin's Police: Order and Mass Repression in the USSR, 19261941 (Baltimore: Johns Hopkins University Press, 2009); Peter Solomon, Soviet Criminal Justice under Stalin (New York: Cambridge University Press, 1996).

6 John Hazard, Law and Social Change in the USSR (Toronto: Carswell Co., 1953).

7 Procurator General of the USSR at the time of the drafting of the 1936 Constitution and Chair of the Drafting Committee's Subcommittee on Judicial Organs, Vyshinsky promoted a codification of legal thought in the USSR, advocating the use of precisely defined penal codes.

8 Solomon, 155, 171.

9 Outside the USSR, Soviet democracy has long been thought to be a prop to legitimize a totalitarian regime, a concept devoid of theoretical depth and separate from European concepts of constitutionalism. The renowned scholar of the Soviet judicial system, Peter Solomon, puts it succinctly: "the concept of constitutionalism in a western sense had no place in the authoritarian order represented by a one-party dictatorship. Rather, in designing a new constitution, Stalin seemed to have had two main purposes: to present the USSR to the outside world as a democratic state, and to enhance the authority, legitimacy and respectability of the Soviet state at home." Solomon, 191.

10 Kotkin, 20-21.

11 J. Arch Getty, "The State and Society under Stalin: Constitutions and Elections in the 1930s," Slavic Review, Vol. 50, No. 1 (Spring 1991), 19-20.

12 For examples, see: GARF, F. R-3316, op. 40, d. 74-The Feb. 6, 1918 English law about voting rights and the new allotment of seats in Parliament and acts about people's representatives from 1928; GARF, F. R-3316, op. 40, d. 75Information about Belgian voting law; GARF, F. R-3316, op. 40, d. 76-The German Imperial Voting law of March 6, 1924, with a proposed law about elections for the Imperial president from March 6, 1924, and an imperial voting order from March 14, 1924 (also includes a second law about the elections for the imperial president from March 1925); GARF, F. R-3316, op. 40, d. 77-Norwegian laws about elections to the Stortinget and changes to the law on December 17, 1920 and March 11, 1930; GARF, F. R-3316, op. 40, d. 78-French election laws and the Declaration of the Rights of Man from August 27, 1789; GARF, F. R-3316, op. 40, d. 79-The Czechoslovak voting law from August 11, 1935 about changes, additions, and suggestions about the elections to the Chamber of Deputies, Senate, Regional, and County representative bodies; GARF, F. R-3316, op. 40, d. 80-Laws, decrees, and resolutions about popular voting and the procedure of popular voting in Bern, 
Switzerland from 1918-1921; GARF, F. R-3316, op. 40, d. 84-The constitutions of various bourgeois countries.

13 Getty, "Excesses Are Not Permitted': Mass Terror and Stalinist Governance in the Late 1930s," Russian Review, Vol. 61, No. 1 (January 2002), 125.

14 Molotov, "Rech' Tov. Molotov o Novoi Konstitutsii," Pravda, November 30, 1936, 2.

15 Iosef Stalin, "Doklad o Proekte Konstitutsii," Pravda, November 28, 1936, 2. In his address to the same body, Chairman of the Council of People's Commissars Viacheslav Molotov reiterated this point: "The new Constitution elucidated all that which has already been won and exists in the country without raising questions of the future, it forms and legally strengthens the great victory of the socialist state of workers and peasants." Viacheslav Molotov, "Ob Izmeneniiakh Sovetskoi Konstititutsii," Izvestiia (February 7, 1935), 1.

16 He was executed as a wrecker in 1938.

17 Nikolai Krylenko, Pravda i obiazanosti sovetskigo grazhdanina, Partizdat TsK VKPb (1936); Osnovnye Pravda i obiazanosti sovetskigo grazhdanina. Partizdat TsK VKPb (1937); Izbiratel'nyi zakon Soiuza SSR, Sotszhkgiz 1937); Soviety deputatov trudiashchikhsia-politicheskaia osnova SSSR, Isdatelstvo TsK VLKSI Molodaya Gvardia 1937).

18 Krylenko, Sovety deputatov trudiashchikhsia-politicheskaia osnova SSSR, 12-13.

19 For more information on this, see: E. A. Rees, Rabkrin and the Soviet System of State Control: 1920-1930 (Birmingham: University of Birmingham Press, 1982).

20 "Beseda tovarishcha Stalina s predsedatelem amerikanskogo gazetnogo ob'edineniia 'Skripps-Govard N'iuspeipers' g-nom Roi Govardom,” Pravda, March 5, 1936, 2. While the draft constitution was not formally issued until June 1936, the drafting commission had been engaged in writing the constitution since July 1935, with a complete first draft being prepared by February 1936.

21 "Candidates will be put forward not only by the Communist Party, but by all sorts of public, non-Party organizations. And we have hundreds of these." "Beseda tovarishcha Stalina s predsedatelem amerikanskogo gazetnogo ob'edineniia 'Skripps-Govard N'iuspeipers' g-nom Roi Govardom” Pravda (March 5, 1936), 2.

22 Stalin's campaign to listen to the "little people" has a similar focus on mass participation as a way of increasing officials' accountability. See Sheila Fitzpatrick, "How the Mice Buried the Cat: Scenes from the Great Purges of 1937 in the Russian Provinces," Russian Review, Vol. 52, No. 3 (July 1993), 299-320.

23 "Beseda tovarishcha Stalina s predsedatelem amerikanskogo gazetnogo ob'edineniia 'Skripps-Govard N'iuspeipers' g-nom Roi Govardom,” Pravda, March 5, 1936, 2. For more on Stalin's deep dislike of and struggles against bureaucracy, see Erik van Ree, The Political Thought of Joseph Stalin: A Study in Twentieth Century Revolutionary Patriotism (Richmond: Curzon, 2002).

24 This argument about enemy elements worming their way into power most likely came from regional Party leaders and not the populace. Arch Getty (“'Excesses Are Not Permitted': Mass Terror and Stalinist Governance in the Late 1930s") notes these complaints were frequent from regional Party leaders, who resisted the implementation of a multi-candidate system from its inception. Getty argues that: "For regional chiefs, free voting for the soviets was a nightmare. If they lost the elections, it could mean 'losing one of their two positions, the soviet one that enabled their leadership.' But even if the resulting legislature was powerless, the regional leaders felt that anti-Soviet 
feeling was strong enough in the country as to threaten Party control, and open elections would give it voice. They resisted the new voting system from the beginning." "Pre-election Fever: the Origins of the 1937 Mass Operations" in James Harris, ed., Anatomy of Terror: Political Violence under Lenin and Stalin (Oxford: Oxford University Press, 2013). This comment, therefore, could be seen as a subtle way of checking their resistance.

25 Stalin, "Doklad o Proekte Konstitutsii," Pravda, November 28, 1936, 4.

26 Molotov, "Rech' Tov. Molotov o Novoi Konstitutsii," Pravda, November 30, $1936,2$.

27 Ibid.

28 For more on the center's contentious relationship with local officials, see: Gabor Rittersporn, Stalinist Simplifications and Soviet Complications: Social Tensions and Political Conflicts in the USSR, 1933-1953 (New York: Harwood Academic Publishers, 1991); and for a specific case study on the problems caused by regional obstinacy, see: Charles Hier, "Party, Peasants and Power in a Russian District: the Winning of Peasant Support for Collectivization in Sychevka Raion 1928-1931," (unpublished dissertation, University of Pittsburgh, 2004).

29 Getty, "State and Society Under Stalin: Constitutions and Elections in the 1930s," Slavic Review, Vol. 50, No. 1 (Spring 1991) and "Excesses Are Permitted': Mass Terror and Stalinist Governance in the Late 1930s."

30 Getty, "State and Society Under Stalin: Constitutions and Elections in the 1930 s," 19.

31 Many of these people also held state positions as well. For example, Molotov was the head of the government as the Chairman of the Council of People's Commissars, Chubar' was Deputy Chairman of the USSR's Council of Labor and Defense, Vyshinsky was the Procurator General of the USSR, Akulov had served as the Procurator General before Vyshinsky, Voroshilov was People's Commissar of Defense, and Litvinov was People's Commissar for Foreign Affairs.

32 This information was taken from Ellen Wimberg's "Socialism, Democratism and Criticism: The Soviet Press and the National Discussion of the 1936 Draft Constitution," Soviet Studies, Vol. 44, No. 2 (1992), 314.

33 The original editing of the recommended draft was done by Iakovlev, Stetskii, and Tal while Stalin weighed in heavily on the review process, then the whole of the committee made changes to the draft Stalin, Iakovlev, Stetskii, and Tal had created.

34 A Party member since 1913, Iakovlev was the organizer and editor-in-chief for Krestianskaia Gazeta from 1923-1929, member of the Central Control Commission from 1924-1930, Commissar of Agriculture USSR from 1929, and head of the Agricultural Section of the Central Committee from 1934. He was arrested in 1937 and executed in 1938.

35 Stetskii was a member of the Party from 1916, serving in the Civil War on the Red Army Staff. In 1923 he began working for various sections of the Central Control Commission and the Worker and Peasants' Inspectorate. From 1926 to 1930, he was head of the Agitprop section of the Northwestern Bureau of the Central Committee and the Leningrad Regional Committee of the $\operatorname{VKP}(\mathrm{b})$. From 1930-1938, he was head of the Agitprop Section for the Central Committee. He was arrested and executed in 1938.

36 A Party member since 1918, Tal' served at the front in the Civil War. He served on the editorial board of Pravda from 1930-1932, and from 1934-1937, he edited various publications, such as Bolshevikaia Pechat', Bolshevik, and Izvestiia. He was arrested in 1937 and executed in 1938.

37 Getty, "State and Society Under Stalin: Constitutions and Elections in the 1930s," Slavic Review, Vol. 50, No. 1 (Spring 1991), 19. 
38 Stephen Cohen, Bukharin and the Bolshevik Revolution: a Political Biography 1888-1938 (New York: Alfred A. Knopf, Inc., 1973), 356-357.

39 Boris Nikolaevsky, "Power and the Soviet Elite: The Letter of an Old Bolshevik and other Essays," Soviet Studies, Vol. 18, No. 1 (July 1966), 105-107.

40 GARF f. 3316, op. 40.

41 "State and Society Under Stalin: Constitutions and Elections in the 1930s," 22.

42 For a good overview of the changes made to the structure of the executive, legislative, and judicial sections of government, see Getty, "State and Society Under Stalin: Constitutions and Elections in the 1930s," 20-22.

43 GARF, f. R-3316, op. 40, d. 5, 1. 1.

44 GARF, f. R-3316, op. 40, d. 5, 1. 1.

45 In the final draft constitution, the soviets kept the name Soviets of Laborer's Deputies, despite Stalin's addition of the label Worker and Peasants' deputies, which was removed in the final version. It would appear that Stalin did not always get his own way,

46 GARF, f. R-3316, op. 40, d. 5, 1. 1.

47 Molotov, "Ob izmeneniiakh Sovetskogo Konstitutsii," Izvestiia (February 7, 1935), 2.

48 This did not go unnoticed by the peasantry and is one of the more contentious issues during the popular discussion.

49 GARF, f. R-3316, op. 40, d. 5, 1. 5.

50 Stalin, "Doklad o Proekte Konsititutsii," Pravda, November 28,1936, 4.

51 GARF, f. R-3316, op. 40, d.5, 1. 42.

52 GARF, f. R-3316, op. 40, d.5, 1. 43.

53 GARF, f. R-3316, op. 40, d.7, 1. 40.

54 "Konstitutsiia (osnovnoi zakon) Soiuza Sovetskikh Sotsialisticheskikh Respublik," Pravda (June 12, 1936), 3. For more on the evolution of women's roles in the Soviet Union and the state's construction of female identity, see Wendy Goldman's Women, the State and Revolution: Soviet Family Policy and Social Life, 1917-1936 (New York: Cambridge University Press, 1993).

55 GARF, f. R-3316, op. 40, d. 5, 1l. 38-39.

56 GARF, f. R-3316, op. 40, d. 5, 11. 38-39.

57 The Young Communist League.

58 GARF, f. R-3316, op. 40, d. 5, 11. 41-42.

59 Stalin's "Little People" campaign shares some of these same features, where the populace was invited to criticize and even denounce members of the state apparatus in a fight against bureaucratism.

60 GARF, f. R-3316, op. 40, d. 7, 1l. 42-43.

61 "Konstitutsiia (osnovnoi zakon) Soiuza Sovietskikh Sotsialisticheskikh Respublik," Pravda, June 12, 1936, 3.

62 GARF, f. R-3316, op. 40, d. 5, 1. 234.

63 Robert C. Tucker, Stalin In Power: the Revolution from above 1928-1941 (New York: W.W. Norton and Company, 1992), 355.

64 For more on the subject, see: Sheila Fitzpatrick, "Signals from Below: Soviet Letters of Denunciation of the 1930s," The Journal of Modern History, Vol. 68, No. 4, Practices of Denunciation in Modern European History, 17891989 (Dec. 1996); Mattew Lenoe, "Letter Writing and the State," Cashiers du monde russe: Russie, Empire russe, Union sovietique, Etats independants, Vol. 40, No. 1-2 (1999), 139-169; and Stephen Coe, "Struggles for Authority in the NEP Village: the Early Rural Correspondents Movement 23-27," EuropeAsia Studies, Vol. 48, No. 7, (1996), 1151-1171.

65 GARF, f. R-3316, op. 40, d. 5, 1. 46.

66 GARF, f. R-3316, op. 40, d. 5, 1. 46. 
67

68

69

GARF, f. R-3316, op. 40, d. 5, 1. 47.

GARF, f. R-3316, op. 40, d. 5, 1. 47.

GARF, f. R-3316, op. 40, d. 5, 1. 47.

GARF, f. R-3316, op. 40, d. 6, 1. 162.

GARF, f. R-3316, op. 40, d. 6, 1. 162.

GARF, f. R-3316, op. 40, d. 7, 1. 42.

GARF, f. R-3316, op. 40, d. 5, 1. 48.

GARF, f. R-3316, op. 40, d. 6, 1. 162.

GARF, f. R-3316, op. 40, d. 6, 1. 42; "Konstitutsiia (osnovnoi zakon) Soiuza Sovetskikh Sotsialisticheskikh Respublik,” Pravda, June 12, 1936.

GARF, f. R-3316, op. 40, d. 5 1l. 43-44.

GARF, f. R-3316, op. 40, d. 5 1l. 43-44.

Works exploring this further: Fitzpatrick, The Commissariat of Enlightenment: Soviet Organization of Education and Arts under Lunacharsky (Cambridge: Cambridge University Press, 1970); Richard Stites, Revolutionary Dreams: Utopian Visions and Experimental Life in the Russian Revolution (New York: 1989); David L. Hoffmann, Stalinist Values: The Cultural Norms of Soviet Modernity, 1917-1941 (Ithaca, 2003).

Sheila Fitzpatrick, “The Bolsheviks' Dilemma: Class, Culture, and Politics in the Early Soviet Years," Slavic Review, Vol. 47, No. 4 (Winter 1988), 602609. Initially an independent organization, by NEP Proletkult came under the jurisdiction of the Commissar of Enlightenment and shortly thereafter became defunct. See also: Lynn Malley, Culture of the Future: The Proletkult Movement in Revolutionary Russia (Berkeley: University of California Press, 1990).

GARF, f. R-3316, op. 40, d. 6, 1. 159.

GARF, f. R-3316, op. 40, d. 7, 1l. 39-40.

GARF, f. R-3316, op. 40, d. 5, 1. 221.

GARF, f. R-3316, op. 40, d. 5, 1l. 44-45.

GARF, f. R-3316, op. 40, d. 6, 1l. 159-160.

GARF, f. R-3316, op. 40, d. 5, 1l. 45-46.

GARF, f. R-3316, op. 40, d. 6, 1. 157.

GARF, f. R-3316, op. 40, d. 7, 1. 38.

GARF, f. R-3316, op. 40, d. 5, 1. 46.

GARF, f. R-3316, op. 40, d. 6, 1. 158.

GARF, f. R-3316, op. 40, d. 7 1. 39.

GARF, f. R-3316, op. 40, d. 5, 1. 46.

GARF, f. R-3316, op. 40, d. 7, 1. 4.

"Konstitutsiia (osnovnoi zakon) Soiuza Sovetskikh Sotsialisticheskikh Respublik," Pravda, June 12, 1936, 1.

GARF, f. R-3316, op. 40, d. 5, 1l. 3-4.

GARF, f. R-3316, op. 40, d. 5, 11. 3-4.

GARF, f. R-3316, op. 40, d. 5, 1l. 3-4.

GARF, f. R-3316, op. 40, d. 5, 11. 3-4.

GARF, f. R-3316, op. 40, d. 5, 1. 3.

GARF, f. R-3316, op. 40, d. 7, 1. 3. Emphasis added.

"Konstitutsiia (osnovnoi zakon) Soiuza Sovetskikh Sotsialisticheskikh

Respublik," Pravda, June 12, 1936, 1.

GARF, f. R- 3316, op. 40, d. 5, 1. 49.

GARF, f. R-3316, op. 40, d. 6, 1. 163.

GARF, f. R-3316, op. 40, d. 7, 1. 43.

GARF, f. R-3316, op. 40, d. 5, 1. 49.

GARF, f. R-3316, op. 40, d. 6, 1. 164.

GARF, f. R-3316, op. 40, d. 5, 1. 50. 
107 GARF, f. R-3316, op. 40, d. 6, 1. 165.

108 GARF, f. R-3316, op. 40, d. 5, 1l. 50-51.

109 GARF, f. R-3316, op. 40, d. 5, 1. 50.

110 GARF, f. R-3316, op. 40, d. 7, 1. 45.

111 "Konstitutsiia (osnovnoi zakon) Soiuza Sovetskikh Sotsialisticheskikh Respublik," Pravda, June 12, 1936, 3. Incidentally, socialist property was already strongly protected by penal codes, which handed down very harsh sentences for theft or damage of collective property. Peter Solomon addresses these strong penalties in Soviet Criminal Justice under Stalin (New York: Cambridge University Press, 1996).

112 GARF, f. R-3316, op. 40, d. 5, 1. 51.

113 GARF, f. R-3316, op. 40, d. 7, 1. 45.

114 GARF, f. R-3316, op. 40, d. 6, 1l.165-166.

115 GARF, f. R-3316, op. 40, d. 7, 1. 45. 


\section{Daily life in Kirov in the 1930s}

Context is imperative for understanding and interpreting the popular suggestions to the draft Constitution. The social and economic realities of the Kirov region in the 1930s shaped how people thought about the issues raised by the draft Constitution and the types of suggestions that they formulated. The Kirov region, formerly called Viatka, was in a period of great transition in the 1930s from a region of independent peasants to an increasingly urbanized and industrialized region with collectivized agriculture. Renaming many of the streets (particularly those with religious names or tsarist names) in the provincial capital for revolutionary heroes and organizations ${ }^{1}$ beginning in 1918, as well as renaming the region and the capital city in honor of Sergei Mironovich Kirov (the Leningrad Party boss who had been born in the city of Urzhum) following his murder in 1934, illustrates one of the many forms this transition took from tsarist and backwards to Soviet and socialist. However, in the mid-1930s, this transition was by no means complete. Many traditional aspects of rural life as well as the traditions of independence and local self-governance that made the Viatka region unique endured even as the social and economic upheavals of the 1930s drastically changed people's way of life. This makes the Viatka/Kirov region a unique and compelling case study. This overview of life in Kirov in the 1930s makes no pretense to be complete. Rather, its purpose is to provide some context for understanding the chaotic and sometimes painful transition of Viatka into Kirov and the impact it had on the daily lives and experiences of those who participated in the constitutional discussion.

The Kirov region is located about 550 miles northeast of Moscow. The Viatka province was amalgamated into Nizhny Novgorodskii Krai (region) in 1930. In 1934, following the murder of Leningrad Party leader Sergei Kirov, a series of administrative reforms split the Viatka region away from the Gorky (Nizhny Novgorod) region and the newly formed region was named for the fallen Bolshevik. The region was predominantly ethnically Russian, with Tatar, Udmurt, and Mari ethnic minorities. In 1934, Kirov Krai occupied a territory of 144,000 square kilometers with a population of more than 3.3 million people. ${ }^{2}$ 
The climate of the Viatka/Kirov region had an important influence on its industrial and political development. Because of its northern climate, the Viatka/Kirov region is agriculturally marginal. The soil in the north of the region is clay and sand, while further to the south it draws closer to the more fertile black earth regions. The climate is harsh, with frosts sometimes occurring as late as July in the region's northernmost reaches. The primary agricultural products in the southern part of the Viatka region were grain and animal husbandry. Flax production predominated in the north, where the growing season is too short for reliable crop production. This made life on collective farms unstable and left peasants vulnerable to hunger and privation. Dairy farming became a far more stable alternative to crop farming. Even today, the Kirov region remains famous for the quality of its dairy products. However, the poor agricultural land in the Viatka region proved to be positive for the political and civic lives of Viatka's peasants. The marginality of Viatka's agricultural land meant that the region's peasants experienced an unusual amount of independence during the Tsarist period. Viatka had very little serfdom, enjoying the highest rates of privately owned land in pre-emancipation European Russia. ${ }^{3}$ Following emancipation, the zemstvo movement was very strong in the Viatka region. Peasants held a majority of seats in Viatka's zemstvos and devoted much effort to public services such as education, which the peasants deemed necessary to conduct business in a wider world. ${ }^{4}$

The poor climate also drove increased urbanization and the longstanding tradition of migratory labor in the Viatka/Kirov region. In the 1890s, over 90 percent of Viatka's peasant households relied on handicraft production or migrant labor to supplement their agricultural income. ${ }^{5}$ Peasants in the pre-revolutionary period provided the workforce in armament and metal-working factories in Izhevsk, Glazov, and Votkinsk. ${ }^{6}$ In the regional capital, Viatka, smaller factories producing leather goods, wooden barrels, and furniture sprang up. As in many parts of Russia, migrant labor proved especially important in forging ties between the city and the countryside and for circulating ideas. ${ }^{7}$ In 1928 , the population of the region was still 91.2 percent rural. The industrial push of the First Five-Year Plan, coupled with the recovery of industry following the Civil War, spurred migration to urban areas. In 1933, the urban population had grown to 13 percent of the total; by 1939, the proportion of urban inhabitants had climbed to 15 percent, with 85 percent of the population remaining in rural areas. ${ }^{8}$

The cities that saw the largest increases in urban population were also the most industrialized and were undoubtedly attracting people as workers to their expanding industries. ${ }^{9}$ The city of Kirov (Viatka) saw the largest population growth, adding 23,500 people to its population between 1926 and 1933. Most of this population gain occurred during the years of the First Five-Year Plan (1928-1933), when industry in the city recovered from the downturns of the Civil War and the investments of the Five-Year Plan began to spur development. Other cities that were connected with targeted 
industries, such as Votkinsk, which housed a large machine-building factory, experienced even higher growth rates-a 43 percent growth in population during the years of the First Five-Year Plan. However, urbanization was not equally distributed among the cities and urban settlements. Cities not closely associated with industrialization, such as Iaransk and Nolinsk, only experienced moderate growth, while the city of Malmyzh experienced negative growth during the years of the First Five-Year Plan.

Despite the implementation of the Five-Year Plans, the Kirov region did not transform into a heavily industrial region overnight. Given the long tradition of craftsmanship in the region, the industrial strength of the Kirov region lay in light industry. Many of these industries, especially those focusing on animal and forest products, had developed during the late Tsarist period and played to the strengths of the Kirov region. Food processing, leather, and fur industries, as well as lumber processing, made up the bulk of the Kirov region's economic output. ${ }^{10}$ Notwithstanding increased industrial growth during the 1930s, many of the enterprises in the Kirov region were small. The two largest enterprises in the region were the Votkinskii Machine Building Factory, located in the city of Votkinsk, which employed 5,458 workers, and the "Squirrel" Fur Factory in Slobodskoi raion, which employed 4,491 workers in 1935. The rest of the region's enterprises were moderate to small in size, employing 2,000 workers or less. Smaller enterprises tended to have less of a proletarian character than larger enterprises, which dominated in regions like Leningrad and Moscow. This fact, combined with the more traditional handicraft nature of the region's economy, meant that many of the enterprises retained their pre-revolutionary character.

Despite these continuities between the Tsarist and Soviet eras, the transition from a Tsarist state to a Soviet one was not an easy process. The ravages of war and instability took their toll on the Viatka/Kirov region. The Civil War, in particular, had a deleterious effect on industry in Viatka. In 1918 and 1919, when the Red Army fought against Admiral Kolchak's forces, Viatka was on the frontlines. The resulting violence led to the death of thousands from famine and disease, and disrupted both agriculture and industry. The Civil War saw a sharp decline in many industries, which had barely recovered by the late 1920 s. $^{11}$ It was only with the industrialization push of the Five-Year Plan that industry in the Kirov region began to grow again. As part of the industrialization drive, socialist competitions and Stakhanovism took hold in Kirov's enterprises, encouraging active worker participation and driving production increases in the mid-1930s. In 1936, 40 percent of the workers in Viatka enterprises reportedly participated in the Stakhanovite movement. ${ }^{12}$ Though factory management, to serve their own ends, often inflated participation figures, such figures also suggest that such campaigns for popular involvement resonated with the population of the Kirov region. ${ }^{13}$

The growth of industry in the Kirov region during the First Five-Year Plan caused a rapid influx of new workers from the surrounding countryside. In 
1931, new industrial workers who had migrated from the countryside made up 33 percent of the workers in Viatka's enterprises. ${ }^{14}$ During the Second Five-Year Plan, the number of non-agricultural workers in the region grew by 48.9 percent (from 133,000 in 1932 to 198,000 in 1937). Some of these new workers stayed permanently; others engaged in seasonal migrant work (otkhodnichestvo). By 1936, about 10 percent of the able-bodied collective farmers were engaged in migrant labor. The Slobodskoi district, which was home to several large fur and forest products factories, saw the highest rate of collective farmers leaving for seasonal work in factories (16 percent), while Biserovskii ${ }^{15}$ raion on the far eastern borders of the Kirov region had the lowest incidence of migrant labor (5.6 percent). ${ }^{16}$

These new workers coming from the villages had difficulty acclimating to factory discipline, the rhythms of which were very different from the rhythms of rural life. This difficult adjustment resulted in a relatively high rate of turnover among industrial workers. For example, in the Kirov district (raion), the annual turnover was 17 percent. Additionally, one in ten of the newly arrived workers were illiterate. In order to address this, factory schools (fabrichno-zavodskoe uchilishche) and courses were created particularly for the newly arrived workers. ${ }^{17}$ Cities proved to be an important place for increasing the educational levels of seasonal workers and their counterparts who remained in cities. These migrant workers who came to staff the developing fur, food, and forest industries in the cities and settlements in the Viatka region continued to serve as links between village and country, bringing a rural frame of mind from the countryside to the city and returning with new Soviet ideas and the expectations of city life to the village. ${ }^{18}$ The fact that workers suggested that they be given land to farm demonstrates that the separation between rural and urban was by no means complete and that many people moved frequently between these two spheres. Like people all over the USSR, Kirovites were being pulled into Stalin's industrial machine, which changed their entire way of life, from the length of the workday, to where they lived, to the type of education they received. The complex nature of this transition is reflected in the discussion of the Constitution, in the increasing delineation of urban and rural needs, and the simultaneously enduring ties between town and country.

The pre-revolutionary traditions of strong local governance, the active involvement of peasants in local governmental bodies, and the firm connections forged between city and countryside continued to shape the consciousness of the inhabitants of the Kirov region through the 1930s. One area where tradition, modernization, urban, and rural interests all coincided was education. The Viatka/Kirov region had a tradition of recognizing the importance of education. During the tsarist period, the peasant dominated zemstvos often devoted most of their attention and budget to elementary education, which the peasants viewed as key to developing small businesses. During the Civil War and NEP era, the Bolsheviks also tried to build educational institutions as part of their goal of destroying the old tsarist culture 
and creating a new socialist society. Under the Five-Year Plans, educational resources grew, though the demand always outstripped the supply. As late as 1936 , seven-year compulsory education was available only in 17 cities and workers' settlements within the Kirov region. Despite the limited geographic spread of higher-level education, the quantity of students attending such institutions grew steadily in the 1930s, from 354,000 in 1935 to 375,000 in $1937 .{ }^{19}$ Education, specifically who could attend educational institutions and what sort of financial support the state should provide for students, was a topic of much debate during the discussion of the draft Constitution.

The Bolshevik government had lacked the resources in the Civil War period to maintain the existing school network, and most schools closed in the early 1920s before experiencing a revival in the 1930s. According to Aaron Retish, the Soviet government had better luck promoting its educational goals through small cultural centers like reading huts during the early NEP period..$^{20}$ Because reading huts and red corners were successful and particularly widespread in Viatka, they became an important locus of communication between the peasants and the state in the early NEP period. ${ }^{21}$ Reading huts and red corners remained an important point of contact between the representatives of the state and its citizens throughout the 1930s, playing an important role as organizational points during the discussion of the draft Constitution.

Other cultural centers were also developed in the Kirov region, particularly in the regional capital. During the Second Five-Year Plan, Kirov city witnessed the building of the House of Soviets, the Drama Theater, the Central Hotel, and the "October" movie theater. At the same time, the local government demolished many historical monuments, such as the Aleksander Nevskii Church, as a way to destroy the old consciousness and replace it with a Soviet one. The network of cultural and informal educational facilities also spread to the countryside, albeit more slowly. In 1936, 667 collective farm and workers' clubs and 50 houses of culture were opened in the region. ${ }^{22}$ Such institutions often played a vital role in the countryside as they provided the primary points of contact between the rural population and the state and Party, which sent officials and representatives out to conduct lectures, readings, meetings, and other events, including the public discussion of the draft Constitution.

In the countryside, however, the main organization that governed everyday life was the collective farm. Collectivization in Viatka had early roots. In 1918, the Soviet authorities launched Committees of the Poor (kombedy) designed to encourage the poor to pool their resources and engage in struggle with kulaks in the villages. While these Committees of the Poor did not flourish in other regions, the movement blossomed in Viatka, which had established 15,573 committees by December 1918, almost double the number of any other Russian province. ${ }^{23}$ Aaron Retish argues that, unlike the Committees of the Poor in other regions, respectable members of the village 
community rather than outsiders staffed the Viatka committees, much as they had staffed the pre-revolutionary zemstvos. ${ }^{24}$ However, the committees failed to control the village communes or to meet the grain requirements of the state and were soon disbanded.

Nonetheless, these Committees of the Poor spawned the first collective farms in the Viatka region in 1918. While these collective farms ran into administrative problems, they still remained appealing to many peasants because of increased access to land, supplies, and modern farming techniques. $^{25}$ Retish argues that, while many of these early collective farms struggled, the NEP era saw not only modernization plans from above but also from below. He notes that before 1917 local village assemblies (skbods) and former zemstvo organizations often pushed forward with agricultural modernization efforts, and that when the Soviet state agencies engaged in such projects, they often retained the zemstvo officials as advisers. ${ }^{26}$ As this suggests, the peasants in Kirov often co-opted Soviet-sponsored initiatives and reworked them to their own advantage, much in the same way they would later co-opt the discussion of the draft Constitution. Thus, collectivization in Viatka, while not without its struggles and hardships, often developed out of state and peasant cooperation and co-utilization, and with far less brutality than seen in the southern and western parts of the USSR.

The early 1930s saw full-scale collectivization and the beginnings of mechanized agriculture. For example, the second half of 1930 saw a new stage in the collectivization of the countryside, when the first Machine Tractor Station (MTS) was built on Viatka territory in Zuevka. It contained 50 tractors and serviced 1,187 collective farms. ${ }^{27}$ From there, collectivization expanded rapidly. At the end of 1932, there were 9,936 collective farms in the Gorky Region, which at that time included the territory of the Viatka region. They unified 240,000 peasant households, or 44.7 percent of the total households. The overwhelming portion of individual smallholders remained in the northern half of the region, where the land was poorer and more forested. In these regions, farmsteads were located in the woods, sometimes as much as four to five kilometers apart, which made movement between them difficult and collectivization almost impossible. In the northern regions, only in Zuizdinskii raion was there any significant collective farm development in the early 1930 s. $^{28}$

The collective farms formed from 1918 through 1932 were weak, often cobbled together out of a few families of former smallholders or landless peasants. Many collective farms did not have storehouses, stables, or livestock farms. The inventory, livestock, and seed were stored in individual houses. Therefore the district and regional Party focused its efforts on bringing the process of collectivization to completion by consolidating gains and strengthening collective farms, particularly those involved in social animal husbandry. ${ }^{29}$ Such efforts by the Party and state paid off as collective farms overall were strengthened and consolidated. In 1928, individual households had 1.1 million head of cattle, but the collective farms only had 410 head. 
But in 1934, the ratio had changed, with individual households having 756,400 and the collective farms having 194,700 head of cattle. ${ }^{30}$ As of the beginning of 1935,77 percent of the peasant households in the Gorky Region had joined a collective farm. ${ }^{31}$

Far from being the monolith often depicted in historical literature, the collective farms of the Kirov region were diverse and fluid. In 1936, the collective farms varied widely in size, ranging from an average of 77 households per collective farm in Kaiskii raion to 18 collective farm households in Murashinskii raion. ${ }^{32}$ Although 35 households per collective farm was the overall average for the region, the number of households in the primarily grain-producing regions was slightly higher, with 37 households, while the flax-producing collective farms had fewer members as a whole, averaging only 33 households. ${ }^{33}$ The rates of collectivization also varied across the various districts within the Kirov region. Verkhoshizhemskii raion was the most collectivized in 1936 , with a 98.3 percent rate of collectivization; Karulinskii raion was the least collectivized, with only 68.3 percent of its cultivated land collectivized. ${ }^{34}$ Overall, 1936 saw a decrease in the rate of collectivization with a total decrease of 0.93 percent in collectivized territory, possibly due to poor harvest or increased urbanization. The steepest rate of decline was in Kirovskii raion, which saw a 10.4 percent decrease in its collectivized land holdings. ${ }^{35}$ However, collectivization prevailed and, at the end of 1937 , there were 10,976 collective farms, unifying 94.3 percent of the peasant households. Collective farms and state farms sowed 99 percent of the region's tilled land. ${ }^{36}$ By 1937 , individual peasant smallholders made up only 5.7 percent of the population, but the conditions in rural Kirov Krai made it clear that central state structures and influence were quite weak. ${ }^{37}$ There was no single collective farm experience in the Kirov region, due to the economic and organizational strengths and weaknesses of the individual collective farms, which resulted in a variety of opinions on some issues. However, overarching concerns such as fairness and the maintenance of law and order, both of which became central issues in the constitutional discussion, united the collective farmers despite the varied nature of their economic lives.

One of the best ways of illustrating the fluidity of the collective farms is by measuring expulsions and households/members who withdrew from the collective farms. Rather than this number decreasing by the mid- to late-1930s as the collective farm system became a fixed part of Soviet life, the number of collective farmers expelled or withdrawing from collective farms actually grew. In the beginning of 1935, 11,100 households were expelled or voluntarily withdrew from collective farms. In 1936, 13,400 households were expelled from collective farms, ${ }^{38}$ and 21,700 households had been expelled by the beginning of $1937 .{ }^{39}$ The question of the exact number of people being expelled from collective farms and the ramifications of this expulsion are not clear, because many of those who were expelled for violations of collective farm rules were later readmitted. 
One of the things that collective farm expulsions illustrate is that, as James Hughes notes, the peasantry is not a homogenous mass and should be viewed as a collection of individuals who often had rivalries and competing interests and who could be appealed to and motivated by common goals, in the case of collective farm expulsions, or state incentives, in the case of the draft Constitution. ${ }^{40}$ Expulsion from the collective farm served as a way for collective farms to regulate the behavior of their members, ensuring that all members pulled their weight and did not damage the economic fortunes of the collective farm upon which everyone was reliant for survival. For example, on March 13, 1934, at the general meeting of the V. Sludka collective farm, Trifon Grigorivich Buldakov, Arkadii Semenovich Buldakov, and Aleksei Vasil'evich Yel'tsov were expelled for the loss of collective farm horses. ${ }^{41}$ The horses were lost in the city of Glazov, when the three collective farmers were taking a sick family member to the hospital. ${ }^{42}$ The meeting participants decided to expel Aleksei Vasil'evich Yel'tsov's whole household, and Arkadii Semenovich Buldakov and Trifon Grigorovich Buldakov were also expelled from the collective farm and sent to court. ${ }^{43}$ However, these expulsions were not long-term. The former two households were soon reintegrated into the community. Vasilii Yel'tsov and his whole family were taken back into the collective farm on the condition that they gave their personal cow to the collective farm in exchange for the lost horse. A. S. Buldakov was also readmitted to the collective farm, but was sentenced to pay 885 rubles for the loss of the horse. He too had his cow confiscated, to cover the price of the lost horse and court costs, and was given a strict rebuke. However, for his negligent attitude to collective farm work and property, T. G. Buldakov was not readmitted into the collective farm, though it appears that his family was. ${ }^{44}$ Once restitution had been made to the collective farm for the losses inflicted upon it (i.e., the price of the horses, which they paid back with credit from workdays and cows given to the collective farm ${ }^{45}$ ), the expelled collective famers, with the exception of T. G. Buldakov, were welcomed back into the collective farm.

Expulsion from the collective farm served as a way for the collective farmers to attempt to impose fairness and order onto a countryside that lacked a strong state presence. Collective farmers had the final say over who was expelled from or admitted to the collective farm, which endowed this organization with considerable power over the daily lives of its members. For example, Anastasiia Stepanovna Ushakova, also from the V. Sludka collective farm, was expelled for a second time. She petitioned the collective farm for readmittance and even had a statement from the Raion Land Organization requesting her readmittance, but the collective farmers rejected her application, stating, "such thieves and spongers are not needed." ${ }^{46}$ As these cases clearly illustrate, at the local level, the collective farmers were quite active in shaping their communities, and their motives were often more a matter of survival than politics. This pattern of cyclical expulsion and readmittance to collective farms led Dokuchaev, the inspector 
from the agricultural section of the Kraikom, to conclude that the question of expulsion from the collective farm and the acceptance of members into the collective farm was not approached seriously ${ }^{47}$ However, he seems to have failed to note the effect that such expulsions had on regulating community behavior, as those expelled from the collective farms were subject to increased taxation as individual smallholders and denied access to collective farm resources.

Collective farm resources became increasingly important to survival in the countryside as more and more restrictions were placed on individual smallholders and individual property. In the early years of collectivization, collective farmers had frequently invested more effort and resources into their own private stock than into the collective farms' holdings. For example, in 1935 many collective farmers, particularly administrators on the 50-household "Flame of Revolution" collective farm (Falenskii raion), maintained substantial private livestock holdings. Mikhail Ivanovich Mil'chakov, the bookkeeper for the collective farm, had three milk cows, a one-year-old heifer, a pig, two piglets, and four sheep. The chairman of the collective farm, Mikhail Ksenofonich Ushakov, had one cow, one Iaroslavl Pedigreed bull, one heifer, a bull calf, a pig, three sheep, and four lambs. Nikolai Gerasimovich Mil'chakov, possibly a relative of the abovementioned bookkeeper, had two cows, two heifers, two bull calves, two sheep, three lambs, and a piglet. Of the 50 households in this settlement, 13 households had at least two cows with calves. At the same time, on the collective farm there were three cowless households. The three families noted above had a disproportionately large amount of livestock, and their heads of house held key posts in the collective farm. The large personal holdings of collective farmers had a deleterious effect on the livestock herds of the collective farm, as well as propagating inequity and jealousy among members. The calving plan for the "Flame of Revolution" farm was not fulfilled in 1934 because the collective farmers invested far more resources into their personal stock holdings than into the collective farm livestock. Additionally, the collective farmers did not give heifers or cows to the collective farm perhaps because they believed that they were able to have an unlimited amount of personal livestock. ${ }^{48}$

As a result of incidents such as these, the Kraikom and Kraiispolkom passed regulations in 1935 limiting the personal holdings of the collective farmers to one cow, one pig with a litter, ten sheep or goats, up to 20 beehives, and unlimited number of birds and chickens, as well as establishing the size of garden plots as between 0.25 and 0.5 hectares. ${ }^{49} \mathrm{With}$ such edicts, the regional officials sought to limit the personal livestock holdings of collective farmers, to promote the growth of collective farm holdings, and to promote equality in livestock holding where collective farmers maintained a large personal holding of livestock. ${ }^{50}$

Despite the best efforts of the Party and state officials to address issues such as "cowlessness," the actual livestock holdings of collective farmers 
varied dramatically from collective farm to collective farm. For example, in 1935, the collective farm V. Sludka in Poninskii raion reported that all its collective farmers had a cow. ${ }^{51}$ However, that same year the "Second Five-Year Plan" collective farm in Falenskii raion reported that, of their 59 households, 19 had no personal cows. ${ }^{52}$ Such discrepancies in household economies continued throughout the 1930s. In the fall of 1937, 22.6 percent of collective farmers in the Krai did not own their own cows and 14 percent had no livestock at all. ${ }^{53}$ Because of the importance of milk cows to the peasant economy, the issue of cattle ownership was raised several times during the discussion of the draft Constitution.

Collective farmers' wages also varied greatly, depending on the success or failure of each collective farm. In the Kirov region, Regional Honor Rolls (краевые доски почета) recognized and tried to promote collective farm excellence. Those successful collective farms featured on the Honor Roll received significantly higher wages, though these too increased or decreased from year to year based on the fortunes of the collective farm. For example, the collective farmers of Krasinskii collective farm ${ }^{54}$ received payment in kind of 3.1 kilograms of food and 10 kopeks per workday in 1934; this increased to 4.5 kilograms of food and 30 kopeks in 1935.55 The "First of May" collective farm ${ }^{56}$ saw an even greater increase in their wages. In 1934, the collective farmers received 2.08 kilograms of grain and 26 kopeks, while in 1935 they received 3.343 kilograms of grain and 1 ruble per workday. ${ }^{57}$ In 1936, the harvest failure of that year saw a dramatic decrease in wages and stood as a stark reminder to the collective farmers of how unstable agrarian life was. Additionally, not all collective farmers, even on successful collective farms, received monetary payment for their work. In 1937, collective farmers on 1,414 collective farms in the region received no monetary pay. ${ }^{58}$

Not surprisingly, the lifestyles of collective farmers varied significantly based on the success of their individual collective farms. For example, in 1935 those in the abovementioned "First of May" collective farm, established in 1928 and containing 54 families, were living a materially secure life. The collective farm was so successful that it made the Regional Honor Roll. It had 837 total hectares of land, of which 450 hectares were arable, 75 hectares were devoted to haymaking, 249 hectares were devoted to pasture, and 63 hectares were forested. It had 45 horses, five young horses, and a dairy farm with 118 head of cattle, of which 42 were milk producing, 38 were heifers, and 28 were two-year-old cows. Every household had one cow, one or two heifers, small animals, and chickens. The collective farm had a cow barn for 220 head of cattle, a horse stable for 36 horses, and they were building a second stable for an additional 20 horses. In 1935, they built a calf barn for 40 calves and a silo. The collective farm also had a club with 200 seats, nurseries with places for 50 children, two grain storage facilities, and a garage for agricultural machines. ${ }^{59}$ This was a prosperous collective farm, and not the only one. Other Honor Roll collective farms, such as the Gredenevskii production collective farm, ${ }^{60}$ offered cultural amenities 
as well. The Gredenevskii production collective farm had five Red Corners, seven nurseries, three cafeterias, one music circle, a portable film projector, a radio set, and various newspapers and magazines. ${ }^{61}$ The production collective farm "Reconstruction" ${ }^{62}$ was a particularly successful collective farm, having bought a truck and a car for the collective farm from grain sales revenue. Additionally, they had electrical lighting for 195 households, had radios in 26 households, and subscribed to 453 journals and newspapers. The collective farm provided its members with access to three nurseries and four seasonal cafeterias, as well as one permanent cafeteria. ${ }^{63}$ Such successful collective farms stood in stark contrast to many others where the standards of living were far lower.

Despite the relatively high standard of living on Honor Roll collective farms, rural life was still strenuous and difficult, often demanding long hours with few breaks. For example, the "Socialism" collective farm, which primarily grew grain and flax, was organized in 1931 and experienced tremendous growth, developing from 15 households in 1931 to 138 households in $1935 .{ }^{64}$ Some of this growth was facilitated by fierce socialist competitions with the neighboring collective farm "Union" in which "Socialism" was the victor, as well as brigade and individual competitions on the farm. These competitions were taken very seriously, with totals from competitions between brigades and individual collective farmers discussed every week at brigade meetings as well as in the wall newspaper. Thirty collective farms' shock workers were awarded prizes for shock work during the spring sowing, in harvest campaigns, and grain deliveries, and above all the collective farm was placed on the Raion Honor Roll. ${ }^{65}$ While such competition facilitated an increase in productive work, the lack of sufficiently mechanized agriculture caused the collective farmers to work to extremes to maintain this output. On the "Socialism" collective farm, the collective farmers began work at 4 or 5 in the morning and finished work at 8 or 9 at night. ${ }^{66}$ Such demands could not be sustained. While these socialist competitions did succeed in raising production in agriculture, as they did in raising productivity in industry, ${ }^{67}$ such rates of production were in fact unsustainable and shock work only masked the lack of mechanization in the Soviet Union that would have made such growth rates more permanent.

Honor Roll collective farms often could not or did not maintain such momentum. For example, until 1933 the collective farm "Red Column" was considered one of the best and most advanced collective farms in the Udmurt Autonomous oblast'. During the 10th anniversary celebrations, the collective farm received the Regional Executive Committee (Obispolkom) banner and had been awarded prizes several times. But beginning in 1933, work discipline weakened, and collective farmers were expelled en masse. In 1933-1934, 25 households were expelled, and in 1935, 35 households from the village of Azim'ia filed a written request to secede from "Red Column." ${ }^{68}$ This exodus and the subsequent decline in the collective farm's economy was blamed on the collective farm's leadership, specifically the 
former collective farm chairman Nikolai Iosifovich Lozhkin, who was condemned for having wild drunken parties, inflating the number of workdays worked, and basically running the establishment into the ground. ${ }^{69}$ Lozhkin stood as a reminder that the fate of a kolkhoz and the well-being of its members often depended on the actions of an individual or a few individuals. ${ }^{70}$ During the popular discussion of the draft Constitution and the 1937 elections, such local leaders came under intense scrutiny.

If strong collective farms occasionally struggled, weak collective farms often faced dire situations. In 1935, the regional agricultural department considered the collective farm "Wave 2 " 71 one of the most backward, lowcapacity collective farms in the region. It was undersupplied with grain for the spring sowing because it had failed to produce a surplus the previous year. It also had production shortfalls of livestock fodder and inadequate grain with which to pay the collective farmers. The raion leadership considered conditions on the collective farm to be catastrophic, particularly the supply of provisions, and was forced to give it loans in December to keep the farmers and their livestock from starving to death. ${ }^{72}$

As the above information demonstrates, there was no one "collective farm" experience in the Kirov region. Those who lived on the successful collective farms and who had experienced often-dramatic increases in the standard of living tended to praise the Soviet state. They greeted the draft Constitution, and especially Stalin, with applause, often supplementing their glorification of Soviet achievements with tales of hardships under the Tsar. I argue that much of this praise was sincere, as their lives had truly improved under the Soviet regime. Conversely, those who lived on struggling collective farms tended to be critical of Soviet power and used the discussion of the draft Constitution as a way to vent their frustrations, arguing that the Constitution was nice, but that it did not feed them. They too were sincere.

The overall agricultural situation in the Kirov region worsened in 1936, when there was widespread crop failure. The first years of the 1930s had seen modest increases in agricultural productivity as land was collectivized. During the First Five-Year Plan, arable collective farmland grew from 2.6 to 3.4 million hectares, and the grain harvest increased from 7.7 to 8 tsenters [100 kilometers] per hectare. In 1933-1934, the grain harvest increased to 9 tsenters per hectare in the Viatka region. ${ }^{73}$ The year 1935 brought some happiness to the populace with a bountiful harvest yield of grain and flax. The grain harvest in the region reached 10.6 tsenters per hectare, and total duties on grain for the first time netted a yield of two million tons. Conversely, in 1936, the hot, dry summer, and an early, rainy, and cold autumn brought a considerable shortage in grain and animal feed, reducing the total number of livestock on the collective farms and the personal holdings of the collective farmers. ${ }^{74}$ In Zuizdinskii raion, a discussant of the draft Constitution stated: "the Constitution is good but just the same we don't have bread." 75 As a result of the poor harvest, resources in the region were strained, and in some areas food became very scarce. In the spring of 1937 , 
hunger spread to Nolinskii, Lebiazhskii, and Urzhumskii raiony. In several villages, people fed on the corpses of collapsed livestock, and the local and regional authorities were inundated daily with calls for help.

Instability was always a threat, be it from natural forces, economic forces, or corrupt or ineffective collective farm leadership. The variations in lifestyle and the success or failure of a collective farm produced an array of opinions, particularly about the effectiveness of the Soviet state. During the discussion of the draft Constitution, collective farmers addressed this instability by calling for access to better resources, demanding the extension of state welfare systems to include them, or calling for the ability to implement their own brand of law and order.

Crime in the Kirov region was an ongoing problem for the citizenry and the state in both cities and the countryside. But the crimes that were of great concern to local officials, primarily the procuracy, and those that troubled the general population, differed greatly. The procuracy was primarily concerned with crimes against the state or state and communal property. In Kirov, the procuracy recorded statistics for 11 types of crime in 1935 and 1936, but only two of those categories were crimes against citizens: property crimes and hooliganism. ${ }^{76}$ In 1935 , the investigative units from the procuracy, the militsia, and NKVD investigated 131 homicides, 55 instances of robbery, and 53 sex crimes. ${ }^{77}$ The procuracy recorded a total of 1,845 instances of property crime against individual citizens for the whole of 1935 , and 737 recorded instances in the first half of 1936. They also recorded 3,031 cases of "hooliganism" in 1935 and 1,200 cases in the first quarter of 1936. However, the procuracy often did not handle crimes against average citizens. Instead, such crimes tended to be investigated by the militsia or the NKVD, so the numbers here probably underrepresent the real crime rate in the Kirov region.

Violence appears to have been of greatest concern in the countryside, where the state's presence was weakest, and social and economic factors may have exacerbated tensions. Local Party reports and raion newspapers often carried anecdotal evidence of violence on collective farms, particularly against members of the collective farm leadership. These may not have been the most common type of crime, but because they were attacks on people who could be perceived as part of the state apparatus and who were often members of the Communist Party, these were the incidents that received the most coverage. Violence against the collective farm leadership was often framed in terms of "enemies of the people" attacking good "representatives of the state" and became the representation of crime in the countryside. "To eradicate Hooliganism," an article that ran in Kirovets (the district newspaper from the Kirov rural district), was a compilation of various letters that the editorial board had received from three different collective farms reporting incidents of hooliganism, encompassing everything from drunken disorders to attempted murder. On the "Red Putilovets" collective farm, one of the collective farmers wrote that, over the course of two 
years, Pavel D. Karavaev and Vasilii A. V. (the last name here was omitted in the text) behaved outrageously (хулиганят). On October 4, 1935, they beat collective farmer I. Ia. Ogorodnikov in the head with a rock, hitting him several times. On Easter 1936, they beat two collective farmers from the "12th of October" collective farm and R. M. Karavakov, a Komsomol member from the "Red Putilovets" collective farm. On "Trinity Day," with the help of Dmitrii Karavaev, Pavel's father, they beat several other people. Later, on St. Peter's day (July 19), the hooligans led young people away from haymaking to binge drink. They subsequently beat collective farmer Ia. I Mel'nikov, tore off his shirt, and hit brigadier and member of the rural soviet, Ogorozhnikov, and his wife several times. They wanted to do the same to the head of the collective farm, but he was not present. The collective farmers were rightfully distressed by the conduct of the Karavaevs and demanded that the procurator quickly bring them to justice.

In Nikulitskii rural soviet, on the Voroshilov collective farm, District Executive Committee Instructor Comrade Kotel'nikov also reported incidents of violence. He wrote that on the evening of July 21, Aleksander Cherepanov organized a binge-drinking session. Then he, his brother, and cousin (Nikolai I. and Ivan M.) assaulted the chairman of the collective farm, P. A. Cherepanov, and a member of the rural soviet and the editor of the wall newspaper, A. N. Cherepanov, dealing them heavy blows with bottles and pickets from a fence. The village executive officer, A. I. Braturkhin, and collective farmer, M. I. Braturkhin, tried to come to their aid while the collective farm chairman and the wall newspaper editor were beaten unconsciousness. But the would-be rescuers were also beaten. All four of the victims were unable to work, and the chairman of the collective farm was beaten so badly that he could not walk. The organizer of the bacchanalia and beating, A. I. Cherepanov, had been expelled from the collective farm and had decided to take revenge on the chairman of the collective farm. ${ }^{78}$ Such violence against collective farm leaders bespeaks sharp social tensions in rural areas, but it also limited their ability to effectively manage the organization and to use expulsion as an effective means of social control.

By collecting and printing such accounts, the newspaper editors brought the specter of violent crime to the forefront of the readers' attention while trying to force local authorities to act. Such cases of violence on collective farms were hardly unique. ${ }^{79}$ As we shall see, violence appears to have occurred with some frequency, and it took a fair amount of effort to get the procuracy to address the issue. On collective farms where the culprits were often well-known, many of the inhabitants of the Kirov region rejected the implementation of habeas corpus, as it delayed the apprehension of the suspects and allowed them to further perpetrate violence. Aleksander Vasil'evich Agalakov, a worker in the finishing section of the Lenin leather factory, gave voice to the popular apprehension behind the widespread rejection of Article 127 (habeas corpus) of the Constitution. In his letter to the Slobodskoi district newspaper, Leninskii Put', entitled "Is it not Early?", 
he addressed the vulnerability that average citizens felt and how article 127 further undermined their sense of security. He wrote that:

In article 127 it says that no citizen of the USSR can be deprived of personal freedom or placed under arrest without the agreement of the court or the sanctions of the procurator. In my opinion it is incorrect and here is why. We have not once and for all eliminated hooliganism. Hooligans sometimes insult and attack passersby and, really, in light of this the policeman doesn't have the right to arrest such a person? In my opinion, this must even be done by any honest citizen.

Then, when we have finally eliminated hooliganism, then this article can be adopted. But now in my opinion it is too early. This is my observation..$^{80}$

Such complaints and newspaper articles demonstrate that the inhabitants of the Kirov region were not shy about agitating for their interests, even if they conflicted with those of the state. Even less-educated rural inhabitants were comfortable and politically astute enough to challenge or use Soviet laws in support of their interests. A case from Zuevka raion in 1935-1936, where collective farmers came into conflict with the district state administrative authorities over land use, demonstrates the tenacity and political astuteness of the collective farmers of the Kirov region.

From March through October 1936, members of several collective farms ${ }^{81}$ challenged the actions of two local organizations, a logging enterprise and the raion roads department, both of which operated under the auspices of the Zuevka District Executive Committee. The collective farms argued these organizations damaged their land's productive capacity as well as infringed on the rights that the central government had recently endowed upon collective farms.

The problem began when the Zuevka District Executive Committee and its District Roads Department decided to construct a road from Zuevka to Bogorodsk. However, the land required for the roadbed, as well as for the gravel to line the roadbed, belonged to functioning collective farms. The fact that the land was occupied by collective farms presented a twofold problem for the Zuevka District Executive Committee. They had to contend both with collective farmers and Soviet law, specifically with the Decree on the Eternal Usage of Land, by which the central government bequeathed all land to the collective farms in perpetuity. Under this law, the land could only be alienated with the consent of the collective farmers.

However, the Zuevka District Executive Committee did not seek their consent, and, in October 1935, ordered the District Roads Department to begin construction on the road. The road cut across the fields of the "Saturday" collective farm, which had been planted with winter wheat. Trenching a planted field, combined with the road technicians compelling collective farmers from another collective farm to build the road, sparked 
complaints. The initial response to the complaint, filed by the road foreman, alleged that the road technician, Maria Semenova Pliner, was guilty of violating the collective farm's rights. She had begun construction without an agreement from the collective farmers, even though they had the state document about eternal land usage. She also allegedly acted against the orders of her superiors, who had told her to halt construction. ${ }^{82}$

Soon more complaints surfaced from other collective farms, which also lost land to the road project. Senior inspector of the Kirov Land Management Department, Zhdanov, was tasked with investigating the legality of the road construction, following the publication of an article entitled, "The chairman of Zuevskii District Executive Committee (RIK) violated Soviet laws," in the local newspaper. Pliner refused to be blamed. On June 12, 1936, she gave Zhdanov information confirming the newspaper story. She stated that the new road ran through the territories of the "Dawn of Freedom" and "Pushkin" collective farms, and that because "Pushkin" collective farm had been officially given the State Act on the Eternal Usage of Land and the collective farmers had not given their consent, the Zuevskii District Land Organization asked officially that the work stop. The collective farmers had referred this question to the Chairman of the District Executive Committee, Comrade Sapozhnikov, who stated "that the work would continue and that the road would be constructed." ${ }^{83}$ The Presidium ordered the Roads Department to deliver gravel for construction, and, despite the protests of the collective farmers, the road was completed. ${ }^{84}$

However, the completion of the road was not the end of the saga. Sapozhnikov seized land from collective farms for the construction of this road in a way that violated both Soviet law and the rights of the collective farms. The land seized from two of the collective farms, "Saturday" and "Chernousy," had occurred before these collective farms received the Act on the Eternal Usage of Land but after the other farms had been granted the land in perpetuity. ${ }^{85}$ The District Executive Committee established a pattern of ignoring Soviet law and used this precedent to further violate the rights of the collective farms. For example, the Presidium of the District Executive Committee, following the approval of the draft securing the land in perpetuity for the "Bubnov" agricultural artel', decided to withdraw 4 hectares of land under the gravel quarry from that collective farm. The Roads Department had failed to reach an agreement on the land in question with the collective farms, but went ahead and began to dig anyway. Doing so reduced the food base for the collective farm. ${ }^{86}$ The protocol of the March 18, 1936 meeting of the Presidium of Zuevka District Executive Committee indicated that the Presidium reviewed the question of land usage for "Bubnov" collective farm and decided against the rights of the collective farm agreeing to remove 4 hectares of land from the collective farm, which encompassed the gravel pit and access road needed for road construction. The Chairman of the District Executive Committee, Sapozhnikov, ordered the District Land Organization to seize the land from the collective farm. ${ }^{87}$ 
The removal of land from the collective farms sparked protests from collective farmers for several reasons. The loss of both valuable arable land and the seemingly unilateral actions of the District Executive Committee threatened both the livelihood and sovereignty of the collective farms. Collective farmers were afraid that more tilled land might be confiscated and hence arable land would decrease further. ${ }^{88}$ Decreases in acreage not only made it difficult for the collective farmers to grow sufficient crops, but in some cases shrank the fields to a size where agricultural machines could not be used.

The collective farm "Pushkin," which also had land seized, refused to accept the actions of the District Executive Committee. At a general collective farm meeting held on June 12, 1936 with 35 of the 45 members in attendance, the collective farmers discussed the actions of the District Executive Committee. Comrade Kuznetsov, chairman of the collective farm, recommended appealing to the regional officials for the return of the land that had been seized, as the collective farm possessed the Act on the Eternal Usage of Land at the time that the land was taken and the size of the remaining fields was inadequate for the use of agricultural machines. The collective farmers unanimously decided to file a written request at the regional level for the return of the land. ${ }^{89}$

Addressed to the Presidium of the Kirov Kraiispolkom, the written request from "Pushkin" collective farm highlighted the above-stated arguments, driving home the fact that the District Executive committee knowingly violated Soviet law and the rights of the collective farm. The collective farmers claimed that the District Executive Committee ordered the Roads Department to seize 8 hectares and dig across 22 hectares of winter wheat, despite the fact that the collective farm had the document authorizing its usage of land. Both the District Executive Committee and the Roads Department ignored the petitions of the collective farmers, so they asked the regional officials to step in. The collective farmers of "Pushkin" collective farm petitioned the regional executive committee to not only return the land to the collective farm but to also provide compensation for damages in the form of lost crops. ${ }^{90}$

At the same time that the "Pushkin" collective farm was petitioning for regional intervention in its struggle with the District Executive Committee, another collective farm was also accusing that committee of violating its rights. The Luzinskii collective farm filed a complaint against Chairman Sapozhnikov as well over damage done to collective farm meadows by a local logging enterprise. The regional officials launched an official investigation into the claim, but only following the publication of a note of complaint in Kirovskaia Pravda on June 7, 1936. On June 10, Senior Inspector of the Land Management Section of the Kirov Regional Land Administration, Zhdanov, conducted an investigation of the incident. He ascertained that the conflict began in the autumn of 1935 when the logging enterprise began to prepare land around the meadows for harvesting. The logging enterprise harvested some 7,000 cubic meters of wood, but ruined the meadows in the process. 
The collective farm chairman, Aleksei Shennikov, asked the foreman of the logging enterprise, Mikhail Ivanovich Dubovskikh, to remove the bark from the meadow so as to enable the meadow's grasses to grow. But Dubovskikh ignored this request and the bark remained. The bark had to be gathered into a pile by the collective farmers, who received no money for doing the work of the logging enterprise. The collective farm chairman alleged that this violated the rights of the collective farm. He also accused the logging enterprise of damage to the meadows, resulting in the loss of approximately 40 hectares of hay, which could have been used to feed 25 cows, 18 horses, four yearling horses, 28 sheep, and 30 heifers. Senior Inspector Zhdanov's investigation concluded that the collective farms' complaints were valid and that the chairman of the District Executive Committee broke Soviet laws because he did not require the logging enterprise to clean up their mess. ${ }^{91}$

At the same time that Inspector Zhdanov was investigating the incidents, the Zuevka District Party Committee was stirred to action by the publication of a June 8, 1936 article in Kirovskaia Pravda entitled, "The Chairman of the Raion Executive Committee violates Soviet Laws." Based on the information provided by the newspaper article, the Party Committee confirmed that there were regulatory violations that damaged the agricultural artely "Pushkin" and "Dawn of Freedom." The Party committee concluded that Comrade Sapozhnikov was the guilty party because he had not observed the state act on the usage of land. The decision to remove land for the road and gravel quarry had been approved by the Regional Executive Committee, but the Zuevka Party Committee concluded that Sapozhnikov did not get the appropriate permission from the Regional Executive Committee or the Council of People's Commissars to take the land from "Pushkin" and "Dawn of Freedom" collective farms. The Party committee concluded that for the violation of the artel' regulations, Sapozhnikov needed to be reprimanded and the collective farms compensated for the lost land. ${ }^{92}$

In the case of "Bubnov" collective farm, the District Party Committee also concluded that the head of the Raion Land Organization, Comrade Nikulin, and the head of the Roads Department, Comrade Makhnev, should be reprimanded because they did not take any action on the complaints of the collective farm about damage to the clover planted near the quarry. The district Party Committee demanded that Nikulin and Makhnev take relevant actions to put up a fence to protect the clover field from possible damage by the gravel delivery people. Additionally, they decided to require the director of the logging enterprise to completely clean the collective farm meadows of garbage left during the winter and to give the collective farms monetary compensation for the cleanup. In order to legalize the land seizure and stay compliant with Soviet law, the District Party Committee decided to ask the Party group of the District Executive Committee to make an application to the Regional Executive Committee about the annexation of the land beneath the new road and gravel quarry and about the grazing lands of the logging enterprise, which the collective farmers used. ${ }^{93}$ While 
the members of the "Bubnov" collective farm did not receive the land under the road back, they were compensated for their losses. They also won recognition of their rights and an acknowledgement from the District Executive Committee that their actions had violated the collective farmers' rights as Soviet citizens and harmed their personal interests.

The collective farmers, in these cases, demonstrated their political acuity by framing their struggle with the District Executive Committee in terms of harming their interests as collective farmers and the violation of central state law. This demonstrated that they were quite familiar with Soviet laws as they applied to their daily lives. Additionally, they appealed to multiple organizations, such as the regional newspaper Kirovskaia Pravda and the Zuevka Party Committee, to investigate the incident and to get justice. And the state rewarded their tenacity and faith. The District Party Committee demanded restitution for the lost land and crops, censured the errant District Executive Committee chairman, and referred the issue to the Regional Executive Committee for further action. The cases above indicate that collective farmers were not afraid to challenge what they perceived as injustice and illegal state behavior, nor were their challenges uninformed. When the Soviet state asked for their input into shaping the foundation of the Soviet state through their comments on the draft Constitution, the citizens of the Kirov region happily complied. For many reasons, not the least of which was that they understood the power of the law, they engaged the state in a public conversation about their needs and expectations, which were often dramatically different than the needs and expectations that the state had been promoting through its managed discussion of the draft Constitution. This incident also highlights a more general reality that influenced how the citizens of Kirov interacted with the Soviet state- the importance of economic realities. In both town and country, citizens who participated in the discussion brought to that discussion their economic experiences and anxieties, realities that formed their perspectives.

\section{Notes}

1 In 1918, Nikoaevskii Street was renamed Lenin Street, Vsesviatskii Street became Derendiaev Street, Vladimirovskii Street became Karl Marx Street, Preobrazhenskii Street became Engels Street, Kazanskii Street became Trotsky Street (though this was renamed Bolshevik Street when Trotsky fell out of favor), and Tsarevskii Street became Svoboda Street. In 1922, Uspenskii Street became Uritskii Street. In 1923, Nikitskoi became Volodarskii Street in Honor of the Commissar of Press Affairs, who had been assassinated in Petrograd in 1918 by SRs. Semyenovskii Street was renamed Vorovskii Street in honor of Vatslav Vorovskii, a Soviet diplomat who was assassinated that year. Other Streets were renamed in 1923 in honor of Vasilii Gorbachev, the first Bolshevik in Viatka, the Scottish revolutionary John Mclean (ул. маклина), Stepan Khalturin, and the Young Guard organization. In 1924, Ostorozhnoi Street became MOPRa Street. Most of these names, with the exception of Engels Street, which has been renamed Preobrazhenskii Street, and Bolshevik Street, which is now Kazanskii Street, again remain. 
2 G.G. Zagvozdkin, "Triumf i Tragediia v 30-kh godov," Istoriiia Ensiklopediia zemli Viatskoi, tom. 4 (administratsiia kirovskoi oblasty, viatskaia torgovopromyshlennaia palata, 1995), 379.

3 Aaron Retish, Russia's Peasants in Revolution and Civil War: Citizenship, Identity, and the Creation of the Soviet State, 1914-1922 (New York: Cambridge University Press, 2008), 14.

4 Retish, 19.

5 Retish, 18.

6 Votkinsk, Glazov, Izhevsk, and Sarapul' were soon removed from the Kirov region, when Udmurtiia became an independent republic at the end of 1936.

7 Retish, 18-19.

8 Larry Holmes, Grand Theater: Regional Governance in Stalin's Russia, 19311941 (Lanham, MD: Lexington Books, 2009), 3.

9 Kirovskii Krai $v$ Tsifrakh, (Moskva:TsUNKhU GOSPLANA SSSR, 1936), 171.

10 It was not until World War II and the evacuation of enterprises to the east that Kirov became a large heavy industrial city and region.

11 Holmes, 5.

12 Zagvozdkin, 383.

13 Lewis Siegalbaum, Stakhanovism and the Politics of Productivity in the USSR, 1935-1941 (New York: Cambridge University Press, 1988).

14 Zagvozdkin, 380.

15 This raion was split from Ziuzdinskii raion in 1935 and merged again with Ziuzdinskii raion in 1955.

16 GASPI KO, f. 1255, op. 2, d. 364, 1. 36.

17 Zagvozdkin, 380.

18 Such patterns of behavior are also noted in Moscow by William Chase, Workers, Society and the Soviet State (Urbana: University of Illinois Press, 1987); and Robert Johnson, Peasant and Proletarian: the Working Class of Moscow at the End of the Nineteenth Century (New Brunswick, NJ: Rutgers University Press, 1979); in Petrograd by Steven Smith, Red Petrograd: Revolution in the Factories, 1917-1918 (New York: Cambridge University Press, 1983); and in the Donbas by Hiroaki Kuromiya, Freedom and Terror in the Donbas: A Ukrainian-Russian Borderland, 1870s-1990s (New York: Cambridge University Press, 1998); and in several works by Theodor $\mathrm{H}$ Friedgut.

19 Zagvozdkin, 387. For a more detailed overview of education policy and its effects on the Kirov region in the Stalinist period, see: Larry Holmes, The Kremlin and the Schoolhouse: Reforming Education in Soviet Russia, 19171931 (Bloomington: Indiana University Press, 1991); and Grand Theater: Regional Governance in Stalin's Russia, 1931-1941.

20 Retish, 223.

21 Retish, 225.

22 Zagvozdkin, 388.

23 Retish, 193-194.

24 Retish, 196.

25 Retish, 219-220.

26 Retish, 222.

27 Zagvozdkin, 379.

28 Zagvozdkin, 380.

29 Zagvozdkin, 382.

30 Zagvozdkin, 380. While the ratio moved to the collective farms' advantage, precisely what accounted for the loss of some 150,000 head of cattle is unclear. This study focuses on Kirov, which during the collectivization drove a part of 
the Nizhnii Novgorod region. An analysis of the collectivization campaign in the latter region is a future research project.

31 Zagvozdkin, 382.

32 GASPI KO, f. 1255 , op. 2, d. 364, 1. 36.

33 GASPI KO, f. 1255 , op. 2, d. 364, 1. 36.

34 This number increases slightly to 69.6 percent in October 1936. GASPI KO, f. 1255 , op. 2, d. $364,1.36$.

35 GASPI KO, f. 1255 , op. 2, d. 364, 1. 36.

36 Zagvozdkin, 385.

37 Zagvozdkin, 386.

38 The number of collective farmers expelled from collective farms is lower in GASPI KO, f. 1255, op. 2, d. 364, being listed as 1979, but this can be accounted for by the fact that many of those expelled were later readmitted to the collective farm, often in the span of two or three months: this number does not include voluntary withdrawals from the collective farm.

39 Zagvozdkin, 385.

40 James Hughes, Stalinism in a Russian Province: A Study of Collectivization and Dekulakization in Siberia (Basingstoke and London: Macmillan Press Ltd. in association with the Centre for Russian and East European Studies, University of Birmingham, 1996).

41 GASPI KO, f. 1255, op. 1, d. 643, 1. 77.

42 GASPI KO, f. 1255 , op. 1, d. 643, 1. 77.

43 GASPI KO, f. 1255, op. 1, d. 643, 1l. 77, 78.

44 GASPI KO, f. 1255 , op. 1, d. 643, 1. 78.

45 GASPI KO, f. 1255, op. 1, d. 643, 1. 74 .

46 GASPI KO, f. 1255 , op. 1, d. 643, 1. 78.

47 GASPI KO, f. 1255, op. 1, d. 643, 1. 73.

48 GASPI KO, f. 1255, op. 1, d. 643, 1. 64.

49 Zagvozdkin, 386. Garden plot size was regulated on a national level as well.

50 Zagvozdkin, 386.

51 GASPI KO, f. 1255, op. 1, d. 643, 1. 71.

52 GASPI KO, f. 1255, op. 1, d. 643, 1. 64.

53 Zagvozdkin, 386.

54 Lugovskii rural soviet, Sovietskii raion.

55 GASPI KO, f. 1255, op. 1, d. 668, 1. 2.

56 Shabalinskii raion.

57 GASPI KO, f. 1255, op. 1, d. 643, 1. 104.

58 Zagvozdkin, 387.

59 GASPI KO, f. 1255, op. 1, d. 643, 1. 104.

60 Gredenevskii rural soviet, Verkhshizhemskii raion.

61 GASPI KO, f. 1255, op. 1, d. 668, 1. 138.

62 Smolentsevskii rural soviet, Sovetskii raion.

63 GASPI KO, f. 1255, op. 1, d. 668, 1. 159.

64 Volozhitinskii rural soviet Kaiskii raion.

65 GASPI KO, f. 1255 , op. 1, d. 668, 1. 38.

66 GASPI KO, f. 1255 , op. 1, d. 668, 1. 38.

67 See Steven Kotkin, Magnetic Mountain: Stalinism as a Civilization (Berkeley: University of California Press, 1997); and Lewis Siegelbaum, Stakhanovism and the Politics of Productivity in the USSR, 1935-1941 (Cambridge: Cambridge University Press, 1988) for a discussion of shock competitions in industry.

68 GASPI KO, f. 1255, op. 2, d. 20, 1. 279.

69 GASPI KO, f. 1255 , op. 2, d. 20, 1l. 280, 282; an entire delo is devoted to Lozhkin's misconduct GASPI KO, f. 1255, op. 1, d. 672. 
70 For a more in-depth look at Nikolai Lozhkin and the case of the "Red Column" farm, see: Samantha Lomb, "Personal and Political: A Microhistory of the 'Red Column' Collective Farm, 1935-36,” The Carl Beck Papers, 2404 (2016) http://carlbeckpapers.pitt.edu/ojs/index.php/cbp/issue/view/178.

71 Lopatinskii rural soviet, Kotel'nicheskii raion.

72 GASPI KO, f. 1255, op. 1, d. 643, 1. 26.

73 Zagvozdkin, 382.

74 Zagvozdkin, 384. 1936 was a terrible agricultural year for much of the Soviet Union and ushered in a nationwide economic crisis. The effects of this crisis on the whole of the Soviet Union were explored by Roberta Manning in "The Soviet Economic Crisis of 1936-1940 and the Great Purges" in Stalinist Terror: New Perspectives eds. J. Arch Getty and Roberta T. Manning (New York: Cambridge University Press, 1993), 117-141.

75 GASPI KO, f. 1255, op. 2, d. 394, 1. 11.

76 GAKO, f. P-2684, op. 1, d. 248, 1. 6; David Shearer investigates state priorities in regards to crime in his Policing Stalin's Socialism.

77 GAKO, f. P-2684, op. 1, d. 248, 11. 10-11.

78 “Iskorenit' Khuliganstvo," Kirovets, No. 126 (June 27, 1936), 2. Other incidents of drunken misconduct, often on the part of collective farm workers, are reported in Kirovets, No. 184 (October 9, 1936), 2 and No. 190 (October 17, 1936), 1 as well.

79 Other such cases are listed in various reports in procuracy materials such as GAKO, f. R-2684, op.1, d. 72, 11. 3, 8, which describes a drunken assault on someone on a train platform with a knife and the beating of a collective farm chairman to unconsciousness.

80 "Ni rano li," Leninskii Put', No. 140 (June 24, 1936), 3.

81 Luzinskii, "Dawn of Freedom" and "Pushkin," "Chenousy," "Bubnov," and "Saturday" agricultural artely.

82 GASPI KO, f. 1255 , op. 2, d. $364,1.82$.

83 GASPI KO, f. 1255 , op. 2, d. 364, 1. 76.

84 GASPI KO, f. 1255 , op. 2, d. 364, 1. 79.

85 GASPI KO, f. 1255, op. 2, d. 364, 1. 79.

86 GASPI KO, f. 1255 , op. 2, d. 364, 1. 79.

87 GASPI KO, f. 1255 , op. 2, d. 364, 1. 81.

88 GASPI KO, f. 1255 , op. 2, d. 364, 1. 79.

89 GASPI KO, f. 1255 , op. 2, d. 364, 1. 87.

90 GASPI KO, f. 1255 , op. 2, d. 364, 1. 86.

91 GASPI KO, f. 1255, op. 2, d. 364, 1. 72.

92 GASPI KO, f. 1255, op. 2, d. 364, 1. 99.

93 GASPI KO, f. 1255, op. 2, d. 364, 1. 99. 


\section{Local realities \\ The implementation of the discussion of the draft Constitution}

The discussion of the draft Constitution began on June 12, 1936 with its publication in the central state and Party newspapers, Pravda and Izvestiia. In Kirov, many local officials responded with enthusiasm and the pomp and circumstance appropriate for such an undertaking. For example, the district officials in Votkinskii raion dispatched 120 lecturers, in cars decorated with slogans and greenery, to organize meetings on collective farms. ${ }^{1}$ While not all district officials chose such an ostentatious way to inaugurate the discussion, local Party and state officials throughout the region hurried to implement the discussion in response to regional and central authorities' demands.

The implementation of the public discussion of the draft Constitution represented an intersection of central goals and local realities. Central Party officials envisioned a six-month-long discussion of the draft where the Constitution would be presented as the embodiment of socialist achievements and which would stimulate citizens to redouble their efforts to build socialism. However, local realities ended up shaping the discussion of the draft into something very different, as understaffed and poorly prepared raion officials tended to treat this as just another campaign, and many citizens expressed opinions that contradicted the goals of the central leadership. Reviewing the implementation of the discussion in the Kirov region allows us to study the tension between what the central Party leadership envisioned and what it was capable of implementing.

\section{How instructors were supposed to guide and shape the discussion}

Central, regional, and local authorities tried to guide and shape the discussion. They utilized press coverage, wrote and disseminated articles about various aspects of the Constitution, and created syllabi for discussions based on published articles from the central press. Two examples of discussion curricula exist in the Kirov archives: one is a lesson plan for correspondence students' study circles in Kirov city; ${ }^{2}$ the other is a list of subject matter for lectures and meetings discussing the draft Constitution. ${ }^{3}$ Neither identifies 
the organizations that created them, but given their placement in the archival record, the first was probably created by someone in the Kirov City Party Committee and the second by the Regional Party Committee as a guide for instructors and other discussion organizers. These syllabi are worthy of note as they illustrate the aspects of the draft Constitution Party authorities wished to highlight and what they wanted students to learn about both the Constitution and the state that issued it.

The lesson plans for correspondence students relied heavily on speeches and articles by Party and state leaders, published in Bolshevik, Pravda, Izvestiia, and Komsomolskaia Pravda, to provide the written texts for the lessons. ${ }^{4}$ Detailed instructions on how to use these texts to highlight important aspects of the draft Constitution accompanied these materials. The lesson plans focused on correspondence students' basic civic education, for example, understanding the basic functions of the government, as well as reinforcing the state-building narrative through a discussion of expanded citizenship rights and the resulting social contract between the state and its citizens. To accomplish these goals, it was essential to discuss and explain socialist notions of constitutionality. The correspondence instructors were told to use Comrade Alymov's article, "The Development of the Soviet Constitution," to demonstrate that only a Marxist-Leninist constitution represented the working people. ${ }^{5}$ This basic lesson was to be followed by a detailed discussion of how the constitutions of 1918 and 1924 had expressed the existing correlation of class strength in the country and how changes in the fundamental class structure from 1924 to 1936 necessitated rewriting the Constitution. Molotov's 1935 speech to the 7th All Union Congress of Soviets, and Stetskii's "About the Liquidation of Classes in the USSR," ${ }^{6}$ were recommended to illustrate the specific forms these sweeping economic and social changes took, such as the closing of the gap between the more advanced working class and the peasantry, as well as the destruction of the exploiting classes. Study circle organizers were urged to present the draft Constitution as the culmination of these achievements, as the "codex of the victorious laborers of our country" and "a world-wide historically important document, reflecting the great victory of the laborers of the USSR under the leadership of the Bolshevik Party." They were further encouraged to highlight the unique democratic and class character of the new Soviet Constitution.

The destruction of the exploiting classes and the creation of universal, direct, and equal elections changed the definition of citizenship in the USSR and brought the issue of citizen rights and responsibilities to the forefront of the discussion. The writers of the lesson plans used an article from Pravda entitled, "The Tireless Concern of the Party and Government," ${ }^{8}$ to highlight the new Soviet social contract codified in the draft Constitution, which was the "greatest document of Stalinist concern (zabota) for the people." This article outlined state monetary and material investment in the population's well-being through increased expenditures on social service funds 
for workers and service workers, increased government spending on education, the construction of public buildings such as schools and clubs, and the provision of "bright new apartments" for urban dwellers. ${ }^{10}$ This massive investment in social projects demonstrated the state's concern for its citizens, confirmed by comparisons to the lesser investments in social services in capitalist countries and an increase in the standard of living since the Civil War. Additionally, the socialist state provided the monetary support for the implementation of some of the fundamental rights that citizens were guaranteed in the draft Constitution, such as the right to education and the right to material security. These points highlighted tangible benefits the state provided for its citizens and demonstrated that citizens had a vested interest in maintaining and strengthening the socialist system.

Reflected throughout the lesson plans was the central Party and state leadership's view that the social contract, which provided the citizens of the USSR with the abovementioned benefits, was a reciprocal arrangement. This demand for reciprocity was highlighted by two articles from Izvestiia, which not only focused on the benefits for citizens, but how citizens were expected to use these rights for the benefit of the state. "The Right to Education" offered a stark contrast between the pre-revolutionary era, when education was difficult for workers and peasants to obtain, and the current situation in the USSR, which offered a vast array of educational opportunities. However, these new educational opportunities were not just a gift to the citizenry. Citizens were expected, indeed, obligated to take advantage of these new opportunities to master science and raise their cultural levels in order to provide the state with a well-trained, well-educated workforce. ${ }^{11}$ The article, "On Equal Rights with Men," followed in the same vein, explained women's poor situation before the revolution and the new opportunities available to them after the revolution. Women were also expected to use their new rights to assume leadership roles in the construction of socialism as collective farm brigadiers and tractor or combine drivers, whose labor served to strengthen collectivized agriculture. ${ }^{12}$ The rights guaranteed to individual citizens were presented as an investment by the state in human capital that should in turn be utilized in the struggle for socialism. ${ }^{13}$

Though less comprehensive than the lesson plan for correspondence students, the list of themes for lectures and meetings provided by the Kraikom also served to reinforce the central narrative of a victorious socialist state, which had created a better life for its citizens and deserved their continuing support. The suggested lecture topics were divided into three main subheadings: "About the Draft of the Stalinist Constitution," "19 Years of Socialist Construction," and "The International Situation of the Struggle for Peace." Much like the previous lesson plans, the section on the draft Constitution focused on themes that the center found important, such as how the state was composed of workers and peasants, the forms of socialist property, and how Soviet democracy differed from bourgeois democracy. The right to work, the right to an education, rights guaranteed to citizens, and duties 
that they were expected to fulfill were also highlighted, again emphasizing the reciprocal nature of rights in the USSR.

The section entitled "19 Years of Socialist Construction" focused on national strength and the policies that were the foundation of the Soviet state, such as the "victory of collective farm construction in the USSR" and the Stakhanovite movement. Likewise, the twin themes, "Lenin and Stalin, the organizers of the October revolution, and the victory of socialism" and "the victory of socialism over the Trotskyite band, who would restore capitalism" emphasized the positive achievements of Party leaders and their interpretation of Marxist-Leninist doctrine.

The section on the international struggle for peace also highlighted the correctness of Party policy and presented the USSR as the defender of freedom, focusing on the "struggle of the Spanish people for a democratic republic and fascist intervention," the Popular Front movement, and the "struggle of the Chinese soviets for the independence of the Chinese people." These were all movements supported by Party policy and Soviet financial and material aid, which allowed the USSR to portray itself as the "bulwark in the struggle with fascist instigators of war." 14 These themes sought to underscore the supposed strength of the Soviet state (though the need for continued strengthening may in fact have demonstrated the leadership's insecurity with the existing levels of Soviet development), the fittingness of state policy and the Party line, and the need for citizens to continue to strengthen socialism.

Both of these documents demonstrate that officials had a prescribed script for the implementation of the discussion, one that emphasized the correctness of the Party line and the obligations that citizens had towards the state in return for their rights and improved quality of life. A report from Slobodskoi raion demonstrated that competent organizers of the discussion were supposed to limit the discussion to the specific interpretations that dominate these syllabi:

The Party organizations gave additional explanations of questions the listeners had not yet mastered, and also reined in suggestions that violated the fundamental principles of the draft Constitution, for example reining in the suggestion that the USSR be called a state of laborers (тр удящихся) and not workers and peasants, etc. ${ }^{15}$

From the leadership's perspective, this was clearly never meant to be a freeform discussion, and the obligation to properly mold the discussion rested with the agitation and propaganda workers.

\section{The organizers of the discussion}

While the Central Executive Committee, the Regional Party Committee, and Regional Executive Committee often issued directives, monitored 
progress, and demanded increased performance and responsiveness from district Party committees and district executive committees, they had little direct involvement with mobilizing and engaging the inhabitants of the Kirov region. This work was carried out at the local level and involved ordinary worker-activists as well as members of the local power structure.

District and local officials participated in the organization of the discussion in two different ways: training people to lead mass meetings and actively leading meetings themselves. This is evident in Shabalinskii raion, where the local leadership organized small conferences for training lecturers and meeting organizers, as well as general meetings with the public. P. A. Iablokov, the chairman of the District Executive Committee, led three raion conferences with a total of 130 attendees, four rural soviet plenums with a total of 180 attendees, and 27 meetings on collective farms that were attended by 1,240 people. ${ }^{16}$ Five other officials worked with more politically active groups, such as local officials and students, who were presumably singled out because of their place in the Soviet social hierarchy, training some of them to be lecturers and meeting organizers. ${ }^{17}$ Local state officials across the Kirov region played an active role in preparing activists to lead the discussion and in conducting the discussion itself. How they did so illuminates how the discussion unfolded.

When reaching out to recruit lecturers and meeting organizers, district Party committees and district executive committees relied heavily on existing networks of Party and non-Party aktiv to organize the discussion. In Slobodskoi raion, the raikom bureau dispatched 308 members of the Komsomol and Party aktiv to organize the popular discussion, with the Party school taking a particularly active role, sending 144 students to 100 collective farms, where they conducted 482 meetings with 19,921 participants (63 percent of the rural population). ${ }^{18}$ In Kirovskii raion, on June $17 \mathrm{a}$ seminar was organized for propagandists, accompanied by three lessons on the draft Constitution in Party and Komsomol political study circles. These raion Party aktiv were then mobilized to discuss the draft Constitution with workers and collective farmers. In total, 320 Party, Komsomol, and nonParty aktiv were dispatched to organize lectures at plenums in 35 rural soviets, as well as lectures and meetings on the collective farms. ${ }^{19}$ Such networks of politically reliable people formed the core group that local officials utilized to implement the discussion, particularly in the countryside where little Party and state infrastructure existed. However, as Roberta Manning has noted, communists made up a very small number of the local administrators, and those who held administrative posts were young, inexperienced, and lacked adequate education. ${ }^{20}$ So while they may have been reliable supporters of the district organizations and enthusiastic about their role in the discussion, they were often overwhelmed by the scope of the organizational activities they were charged with.

Other civic organizations, such as trade unions, teachers' organizations, and street committees, played important roles in the implementation of the 
discussion. In Pizhanskii raion, general collective farm discussion meetings and smaller brigade meetings were carried out by 28 members of the District Party Committee and the District Executive Committee, 30 individuals from the Komsomol and trade union aktiv, and 121 teachers and rural aktiv. ${ }^{21}$ Shabalinskii raion utilized 126 teachers and 300 readers from the aktiv to lead the discussion. ${ }^{22}$ These civic networks supplemented the core Party and aktiv networks in the countryside and the cities, where they were the main organizational networks for non-working urban residents. For example, in the city of Kirov, street committees and groups affiliated with the city administration conducted meetings among otherwise isolated groups, such as housewives and disabled people. ${ }^{23}$ These networks were instrumental for organizing the discussion, providing existing social hubs that raion officials could readily use, but they ran the risk of excluding some groups. Limited resources and the enormous scope of the tasks prevented even the non-communist administrators from extending their authority much outside their patronage and kinship networks. ${ }^{24}$ For example, in Slobodskoi, the city soviet was accused of not reaching out to a broader audience as the discussion at the liquor factory was limited to Party study circles and not discussed among the workers as a whole..$^{25}$

Party, Komsomol, and aktiv members provided most of the lecturers and meeting organizers for the discussion of the draft Constitution, but their political affiliation only represented part of their social identity. The majority of these lecturers worked either in local administrative positions or in industrial enterprises. A report from Slobodskoi raion detailed the occupations of 127 people dispatched to collective farms in the raion. Sixty of those recruited to lead discussions worked in light industry, producing leather goods, matches, and alcoholic beverages. Forty-six of the recruits worked in some kind of administrative position. Among their ranks were members of the trade organization (TORG), the machine tractor station, the social benefits office, the match distribution department (ORS Spichk), and the raion educational, financial, health, and land administrations. Their numbers also included a people's investigator, two members of the Slobodskoi city soviet, four NKVD officials, a postal worker, and 14 rural soviet chairmen. Six people came directly from educational institutions; only six individuals were recruited directly from the collective farms. ${ }^{26}$ Likewise, 656 people were selected to organize lectures and meetings on collective farms in Shabalinskii raion. Of them, 26 were rural soviet chairmen, 85 were members of rural soviets, 14 worked at the general store (sel'po), 12 worked for the schools, 85 were collective farmers, and 320 were identified as newspaper readers. ${ }^{27}$

As this data indicates, the people charged with conducting the discussion of the draft Constitution were often residents of urban and raion centers; the administrative elite in the town and countryside. They brought an administrative understanding to the implementation of the discussion and may have found it harder to relate to their collective farm audience, who were less well-educated and less familiar with the theories that the central 
authorities deemed vital to the discussion of the draft Constitution. They were drawn from existing Party and state networks and had to shoulder the duty of conducting the discussion of the draft Constitution, in addition to their own obligations as administrators, workers, or teachers. As a result of their many commitments and the number of total meetings they were responsible for organizing, the discussion of the Constitution was often cursory, or in some cases non-existent, as the overburdened raion officials and aktiv struggled to implement the discussion with little logistical or material support. Numerous problems that arose during the implementation of the discussion were related to these issues. Nevertheless, many made honest efforts to lead the discussion of the draft Constitution, and beginning in June the discussion organizers went forth from the raion centers armed with newspapers and copies of the draft Constitution.

\section{Implementation of the discussion of the draft Constitution}

The implementation of the discussion was a complex process involving the coordination of multiple levels of Soviet administration; the mobilization of the national, regional, and local press; and the utilization of preexisting Party and state educational and patronage networks. Mary Buckley notes similar intricacies in the implementation of Stakhanovite policies in the Soviet countryside. Administrative decisions, made in the upper echelons of the system, were transmitted to the local administrators, newspaper editors, or collective farm leaders who should implement them. District officials, based on their local or personal situation, would then choose to obey the order, partially implement it, ignore it, or actively avoid it. These responses, in turn, prompted reactions from the initiators of the original order ${ }^{28}$ These same processes were present during the discussion of the draft, with local administrators choosing how completely to implement the discussion based on their skill level and other demands on their time and participants interpreting the text of the draft Constitution as it suited their needs.

The discussion was implemented more fully in accordance to the central leadership's vision and with far less negotiation in urban areas, where the Party and state networks were more fully formed and integrated into urban life. This discrepancy is evident in the scope and depth of the discussion in urban areas, compared with the countryside, where communists were few and the Party and the Soviet state was less entrenched. However, even in urban areas, the demands of implementing such a large-scale campaign often proved to be too much for many already overtaxed local officials. As a result, in many cases the grassroots discussion failed to meet the high expectations of the central and regional leaders, who blamed local and district officials for the many problems that arose.

Most district officials chose to utilize a simple, lecture-style discussion of the draft. For example, the inhabitants of Pizhanskii raion discussed the draft Constitution multiple times, first at a general collective farm meeting 
and then in brigades, where the draft was read out by section and article. The meeting leaders read every article out loud, often several times, then explained them, after which they expressed their opinions of the article to the assembled. ${ }^{29}$ This method proved ineffective overall because these pointby-point discussions often turned into a discussion of other matters, such as economic and political campaigns, loans for haymaking, and preparations for harvesting rye. Daily realities and the legal complexities of the discussion often distracted or befuddled participants. ${ }^{30}$

The district officials of Sovetskii raion, however, broke with the simple point-by-point reading of the draft that dominated the discussion in many districts. While also occasionally relying on reading and discussing the various points of the draft Constitution, the Sovetskii district organizers explained the demonstrable benefits of the draft Constitution and used diagrams and other visual aids to prove their point. ${ }^{31}$ The Sovetskii district officials submitted a rather extensive plan for expanding explanatory work in the district. Their proposal included: plans to hold meetings with the pupils at all the schools, construction workers of all specialties, and service workers of various enterprises, as well as organizing meetings in the Sovetsk city districts and on collective farms where the draft had not yet been discussed. In order to ensure that meetings were being run effectively, they proposed having organizers listen to the secretary of the Regional Party Committee's report entitled, "About the progress of the explanation and discussion of the new draft Constitution"; keep statistics on the number of additions, corrections, and suggestions to the new draft Constitution; and systematically verify the work of propagandists during the discussion. The local leadership also proposed having the Party educational center (парткабинет) and the district library organize an exhibition devoted to the new draft Constitution and the discussion of that document in the press. They had even assigned individuals responsibility for the completion of each of these tasks. ${ }^{32}$ Such an expansive and detailed plan appears to have been exceptional, but local leaders in Sovetskii district organized a total of 391 meetings with 20,305 participants as of the beginning of September. ${ }^{33}$

While the implementation of the discussion may have varied from district to district, the networks upon which district officials relied for the dissemination of information and which served as organizational hubs for the discussion remained largely consistent. The press and Party and educational networks provided the most efficient means of organizing and implementing the discussion of the draft Constitution. The printed press and, to a lesser extent, radio played an important role in disseminating information about the draft Constitution to a large audience, and newspapers performed vital monitoring and didactic functions as well. Local officials often organized large-scale radio listening sessions. A report from the Regional Party Committee noted that on June 11-12, 12,000 laborers in the Kirov region listened to the text of the draft Constitution on the radio. ${ }^{34}$ In Omutninskii raion, group meetings to listen to the radio lectures of comrades Stetskii, 
Vyshinsky, Krylenko, and Shvernik attracted a large audience. Stetskii's lecture reportedly attracted 396 communists, 98 sympathizers, 200 Komsomol members, and 150 members of the non-Party aktiv. ${ }^{35}$ But because of the limited technology in the Russian countryside, radio only played a supplementary role in the discussion. The printed word was the main vehicle for conveying information and publicly critiquing the discussion.

On June 15, the Shabalinskii district newspaper printed out 2,200 copies of the text of the Constitution and ran 20 separate issues, which touched on the progress of the public discussion of the Constitution. Kraiispolkom instructor, Gromov, noted that in Shabalinskii raion one would be hard pressed to find someone in the district who was not familiar with the draft Constitution due to the work of the district newspaper. ${ }^{36}$ The Pizhanskii raion newspaper also very actively promoted the discussion. It published 14 articles on the Constitution, 12 articles about the progress of the discussion, 29 individual collective farmer statements, and 21 notes from laborers about the draft. In all, it devoted a total of 76 newspaper articles to the draft Constitution. ${ }^{37}$ Additionally, the regional newspaper played an important role in publicizing the discussion. As of September 17, Kirovskaia Pravda had printed over 100 testimonials and suggested additions to the draft Constitution..$^{38}$

As previously mentioned, newspaper articles written by central authorities provided discussion materials for study circles and meetings. Agitators in Slobodskoi raion took advantage of the widespread press coverage to familiarize the participants of meetings with additions and corrections and often used material from the local press, Pravda, and Izvestiia to address questions regarding the draft Constitution. The use of newspaper materials helped liven up the meetings and connect the discussion back to the statebuilding narrative that central authorities wished to underline. ${ }^{39}$

The press did more than spread information and focus popular discussion. It also called to task officials and other organizers who were not properly managing the discussion. Kirovskaia Pravda ran a series of articles detailing the failings of local officials. By presenting investigative articles on local officials' failures, they not only criticized those who failed but demonstrated the kind of behavior that was deemed inappropriate to a broader audience of discussion organizers. In an article entitled, "The Mistakes of Mozhga City Soviet," the author, Nazarov, described how poorly the city soviet discussed the draft Constitution and how this lackadaisical attitude affected the discussion in general in the city. The discussion was initiated at a poorly attended plenum of the city soviet where just half the deputies were present and only two or three participated in debate after the formal report. The general discussion in the city was also poorly organized and attended. Of the 1,500 people listed in the "unorganized" population of the city, only half discussed the draft Constitution. About 20 meetings were held throughout the city, but no meeting minutes existed for them because the deputy director of the city soviet gave an order to not write them. Six additions to 
the draft Constitution were recorded, but it was unclear who made them. This dismissive attitude was reflected in the attitudes of other local leaders, whom Kirovskaia Pravda also took to task. ${ }^{40}$

Kirovskaia Pravda highlighted that the wrong kind of discussion could be just as harmful as no discussion in "The Mistakes of a Raiispolkom," which focused on the Bogorodskii District Executive Committee's mistaken transformation of the TsIK directive for discussion (obsuzhdeniia) into a cursory "working up" (prorabotka) of the draft Constitution and the negative effects that this had on the discussion in the raion. The author, $\mathrm{M}$. Vakhnin, from the raion center, Bogorodskoe, noted that instead of implementing the Central Executive Committee directive, the raiispolkom sent out "this mistaken illiterate directive" to every rural soviet chairman:

In the absolute majority of the rural soviets the working up (прорабо тке)!? ${ }^{41}$ of the draft Constitution has not begun. The presidium of the raiispolkom thinks its importance is underestimated. We ask that every collective farm chairman personally organize the working up over the course of three or four days.

Vakhnin accused the District Executive Committee of "debasing the Constitution with their bureaucratic game" through the use of the term "working up," which had a devastating effect on the quality of the discussion. Vakhnin reported that at the plenum of Basharskii rural soviet, "the greatest document of the era was discussed as such: "listened to Mikriukov's 'working up' of the draft Constitution, Resolved: the draft was adopted and 'worked up' on every collective farm." Similarly, the members of Veprevskii rural soviet listened to Comrade Anisimov's "working up" of the Constitution and decided to adopt it without discussing the draft at all on the collective farms. Though he blamed the raiispolkom directive for the poor quality of the discussion in the raion, Vakhnin also held the local newspaper culpable for not correcting this mistake. He claimed that the editorial board of the raion newspaper, Kolkhoznaya Zaria, "knew about the mistake committed by the District Executive Committee and the rural soviets but remained silent." 42 The failure of local officials to conduct the discussion in a proper manner meant that in many areas the Constitution was not discussed as Soviet leaders had intended. The press (specifically Kirovskaia Pravda) fulfilled its role as watchdog of the state and investigator of complaints by exposing these shortcomings as a way to redress them and to demonstrate that the poor implementation of the discussion of the draft Constitution was not acceptable and would not go unnoticed.

The press also played a didactic function, providing a template of how to conduct the discussion by allowing organizers to share both the mistakes that had been made during the discussion as well as their successes. On October 29, Kirovskaia Pravda published a series of articles on organizers' experience designed to showcase these difficulties and achievements. In the 
article "My Mistake," Semyon Teren'evich Utrobin, a gauger at a fur and lambskin coat factory, recounted his experience organizing study circles for the factory's workers living in dorms and communal housing, those who studied at home or on weekends, and for the remainder of the workers who gathered in sections after work on the last day of a five-day shift. The circles were very successful, and many participants offered additions and suggestions. However, Utrobin had not considered it important enough to record these suggestions but planned to remedy this mistake over the course of the next two or three days. ${ }^{43}$ Likewise, in her article, "In Place of In-depth Study, Reading Aloud," Elizaveta Vasil'evna Iakimova, a senior dryer at the leather combine, reported that she had established a constitutional discussion circle that 30 of her 42 colleagues regularly attended. However, the circle was poorly led. The director of the combine, Comrade Iabloko, led the study sessions, but rather than discussing and analyzing every point of the Constitution, he only read the draft aloud. The group met irregularly, and although Iakimova had asked the Party committee for a special day devoted to the work of the circle, it had not yet provided an answer. ${ }^{44}$ Leadership was also a problem in the study circles of the Comintern leather factory. In his article, "To better select the leaders of circles," Veniami Ignat'evich Laptev described how he had helped to organize a study group in his section of the factory and how this group had chosen an old Bolshevik, Comrade Presnetsov, to lead them. He was considered a good choice because he was politically educated, but Presnetsov knew it and dominated the circle. Many workers left lessons dissatisfied and with many baffling questions. Laptev noted that it was necessary to pick better leaders and to organize special seminars for them. ${ }^{45}$

While these organizers of study circles had attracted participants eager to study the draft Constitution, they had failed to record popular responses, or there were leadership problems that made the discussion experience frustrating for the participants. The ideal discussion experience was captured in N. Shevnin's letter, "Seminars for the Discussion of the Constitution," which described the implementation of the discussion in Pizhanskii raion. He noted that in all the rural soviets in Pizhanskii raion, there were two-day seminars to study the Stalinist Constitution. Thirty to 35 people participated in each seminar, including members of the rural soviets, auditing committee members, chairmen of collective farms, and Stakhanovites. Members of the District Party Committee, the presidium of the District Executive Committee, and the district Party aktiv led the lessons. The population was deeply involved in the discussion and proposed many suggestions. ${ }^{46}$ Not only did this well-organized discussion generate suggestions, but they were all dutifully recorded. Shevnin's letter illustrated all the key components that central and regional officials were looking for in the implementation of the discussion: a well-prepared and involved rural leadership and an active and lively discussion that generated many suggestions that were recorded and sent to the press or central officials. The first three articles illustrated 
the pitfalls that organizers should try to avoid, while the fourth provided a template for a successful discussion.

The timing of these articles reflected a resurgence of the discussion campaign in preparation for the congresses of Soviets in the fall. Chronologically, the discussion was strongly promoted after the initial publication of the draft Constitution in June and then again in the fall in preparation for the district congresses of Soviets and the regional congress of Soviets. The attention from the press and regional officials spurred raion officials to concerted action in June. A region-wide campaign to conduct meetings and assemblies took place in Kirov (city) and in a majority of the other cities in the region, in factories, villages, collective farms, and enterprises from June 12 to $20 .{ }^{47}$ Regional officials came out to support local officials in their effort to engage the populace in the discussion. On June 16, at a meeting in the city of Kirov, the secretary of the Regional Party Committee, Comrade Stoliar, highlighted the importance of the ongoing discussion by giving a report about the draft Constitution to an audience of 17,000 people. ${ }^{48}$ However, by the end of June, attention to the discussion of the draft had waned. An instructor from the Regional Executive Committee noted that as of October 19, only 65.1 percent of the work-aged population in Kirovskii raion had participated in a discussion of the draft. The ebbing of the discussion during the summer months resulted from various factors, including the demands of the growing season, cadres' fatigue after the initial push, and a sense among many that they had done their job. Nonetheless, the preparations for the district congresses of Soviets sparked renewed efforts to engage the population in discussing the draft.

An overview of the discussion in Votkinskii raion provides the best example of this ebb and flow. On June 12, 8,000 urban and rural workers attended meetings to discuss the draft Constitution. Four-hundredand-forty-seven people attended a plenum of Norodskii soviet, Votkinskii raion, to discuss the draft Constitution on June 15. Additionally, in June, 5,632 people attended the constitutional discussion meetings in the factories and enterprises of Votkinsk, where they asked 372 questions and actively engaged in debates. On June 22, the Votkinsk street committees organized meetings in nine locations, which attracted 1,153 participants. However, no other activities related to the discussion of the draft Constitution were reported until August 28, when the city soviet presidium decided to organize seminars for the leaders of the deputy group sections and leaders of the street committees on the draft Constitution. On September 3, 560 people attended a plenum at which the progress of the discussion of the draft Constitution was examined. ${ }^{49}$ As this example makes clear, the discussion had a certain rhythm. No mention of the draft Constitution was made for two months during the summer, but in the fall, at the time when preparations were made for the district congresses and the harvest had been brought in, the leadership of Votkinskii raion once again made the discussion of the draft Constitution an important issue. 
The most complete picture of the day-to-day workings of the discussion of the draft comes from Slobodskoi raion. The data provided by the Slobodskoi District Party Committee showed significant differences in the way that the discussion was conducted in the rural and urban parts of the raion. The number of meetings and meeting participants, the type of suggestions offered, and whether the discussion happened in large general meetings or in smaller study circles all serve to illustrate the marked difference between the discussion in the cities and in the countryside. While the data from the collective farms is incomplete, it would appear that most collective farms hosted only one meeting on the draft Constitution. These meetings not only failed to engage with most of the collective farmers, but also tended to have a campaign character, which precluded lengthy discussion, and were often limited to point-by-point readings of the text followed by questions. In Slobodskoi district, 261 meetings with a total of 8,291 participants were organized on the collective farms, with an average of 32 participants per meeting. ${ }^{50} \mathrm{~A}$ total of 237 suggestions were proposed, 171 (70 percent) were collective or group suggestions, 59 were made by individuals, and seven were classified as not relevant to the Constitution. On the seven collective farms that provided complete data, only two thirds (65.9 percent) of the total population participated in the discussion of the draft Constitution. ${ }^{51}$

The better-established Party and state networks in the rural soviets allowed for multiple meetings and a more in-depth discussion of the draft Constitution, though as can be seen, increased participation did not mean an increased adherence to the topics approved by the central leadership. In fact, in Slobodskoi district, increased participation seems to have corresponded with a marked increase in "irrelevant" suggestions. Meetings conducted in the rural soviets, rather than on the collective farm, had a significantly higher rate of participation. An average of twelve meetings focused on the draft Constitution were held in each rural soviet, ranging from two seminars in Morozovskii rural soviet to 28 meetings in Volkovskii rural soviet. A total of 16,873 participants attended 293 total meetings (an average of 58 participants per meeting). The participants offered up 459 suggestions: 174 (37.8 percent) collective suggestions, 84 (18.3 percent) individual suggestions, and a whopping 201(43 percent) suggestions, which were deemed not relevant to the Constitution. ${ }^{52}$

In the urban areas, where Party and state networks were the strongest, the percentage of the population that participated in the discussion of the draft Constitution was the greatest, and many of the industrial workers made individual suggestions. In the industrial enterprises in the city of Slobodskoi, 82 meetings took place in ten different enterprises, ranging from two assemblies in four of the smaller factories to 48 meetings in the largest enterprise, the "Squirrel" fur factory. The seminars averaged 66 participants and a total of 5,380 people, or 87.2 percent of the industrial workers of the city, participated in the discussion of the draft Constitution. A total of 17 suggestions 
were made at these meetings: the participants offered four collective suggestions and 13 individual suggestions. ${ }^{53} \mathrm{~A}$ similar trend held true for the industrial enterprises in the rest of the raion. Ninety-five total meetings were held in eight enterprises, ranging from two meetings in the Kustarka artel' to 40 meetings in the "Spas" fur factory, with an average of 48 participants per meeting. Some 5,589 people, or 87.8 percent of the total industrial population, participated in the discussion. They offered up 15 suggestions to the draft Constitution: five collective suggestions and ten individual. ${ }^{54}$

However, the participation data for the non-industrial urban population, who relied heavily on local civic organizations to organize the discussion, more closely resembled that of the rural areas than the highly organized industrial enterprises. In the city of Slobodskoi, 12 civic organizations, such as the housing trust, the postal organization, street committees, and housewife organizations conducted 23 meetings with 730 total participants (an average of 32 participants per meeting). An average of 1.9 meetings were conducted per organization, ranging from one assembly in seven organizations to four seminars in Mekhovshik. The participants offered up a total of 43 suggestions: seven were group suggestions, but a massive amount (27, or 79.4 percent of suggestions) were considered irrelevant to the draft Constitution. ${ }^{55}$

All of these numbers point to one obvious fact-the discussion among the urban industrial population was much better organized than elsewhere, even if the number of meetings and participants seems comparatively modest in comparison to the much larger rural population. The segments of the population, which had fewer nodes of daily interaction with the Party and state, did not engage in in-depth examination of the draft Constitution in study circles. District Party Committee officials themselves acknowledged this shortcoming:

It is necessary to note that if in the city and among the industrial workers, the discussion of the draft Constitution proceeded systematically and had a broad reach, then in the countryside the discussion proceeded poorly and to a considerable extent had a campaign-like character. ${ }^{56}$

While the press, radio, and organizers dispatched to the countryside succeeded in involving collective farmers in the discussion, poorly prepared and overworked cadres combined with a weak base of support in the countryside led to an overall more cursory discussion of the draft Constitution in the rural areas of the Kirov region. A campaign-style mentality was more widespread in the countryside, leading in many cases to an overview of the text rather than a real discussion. Like all Soviet campaigns of the period, the discussion of the draft Constitution experienced difficulties that stopped it from becoming the nationwide discussion that the central Party and state officials had envisioned. These failures, discussed below, drew the ire of the central leadership. 


\section{Problems with the discussion of the draft}

Like all Soviet campaigns, the discussion of the draft Constitution was plagued by problems. Many of those dispatched to conduct the discussion were ill-prepared and ill-suited for the task. The Kirov city soviet noted problems with a particular propagandist, comrade Glukhikh, whose lessons on the Constitution were poorly prepared. He read the Constitution section-by-section and, after the reading of each section, asked the listeners, "what is not clear to you"? Because the listeners poorly understood the material and did not wish to embarrass themselves, they did not ask any questions, and Glukhikh proceeded to read on. ${ }^{57}$ Poor preparation was also the hallmark of the study circles in the KUShTO Combine. ${ }^{58}$ Three communists, comrades Buldakov, Sozontov, and Zubartov, led these discussion circles, and they performed badly. Upon inspection, Comrade Buldakov's circle had only 31 out of its 62 members present. The lesson began with a rapid reading of the Constitution because people were anxious to leave. As the leader of the circle, Buldakov was not able to answer listeners' questions and did not conduct a more in-depth study of the draft Constitution. Comrade Sozontov's circle had 41 of its 48 members present, but no women participated. Sozontov did not read the Constitution beforehand and had not thought about how to present the material, and consequently stumbled through the text. Comrade Zubartov's circle had 71 of its 80 members present at the beginning, but ten people left during the course of the lesson. $\mathrm{He}$ also read poorly, stumbling over words. At the end of an article, he would ask the listeners if they understood; if they said yes or were silent, he moved on and did not delve deeper into the text. In every case, the circle leaders did not provide examples that would help listeners understand the Constitution better, and they were also rather incompetent at answering questions. ${ }^{59}$ This cursory overview of the draft was clearly the opposite of what the central and regional officials had intended and only served to further alienate the listeners.

Lecture attendance and overall participation in the public discussion was an ongoing problem. In the city of Kirov, an investigation into the implementation of the discussion found that study circles had trouble attracting and keeping members, as many were poorly organized and met infrequently. In the Stalinskii district of Kirov city, 50 out of 255 circles were not functional, and the remaining had conducted only two or three lessons. The industrial enterprises in Kirov had similar problems. In the KUTShO combine, all 48 circles carried out three lessons, but never had 100 percent attendance. ${ }^{60}$ Forest Factory No. 2 had 340 people organized into seven study circles that conducted four lessons and had an overall attendance rate of 66 percent. The lessons in these circles consisted only of readings; no in-depth analysis of the articles of the draft Constitution occurred. ${ }^{61}$ In Slobodskoi raion, attendance in some productive enterprises was likewise low. At the beer factory, only 167 of the 266 workers and service personnel had discussed 
the draft, and only 37 of the 116 workers and service personnel at the artel' "Mashinostroitel"” had done so. ${ }^{62}$

Regional officials blamed raion administrators' inattentiveness for the inactivity and poor work of the local organizers. A report from Kirov TASS (the Kirov section of the Telegraph Agency of the Soviet Union) noted that in Iaranskii raion, Abramycheskii rural soviet, the local communists were not working very hard (палец не ударили) and had not conducted a single meeting with collective farmers to explain the draft Constitution. ${ }^{63}$ While these shirkers were identified by name, Kirov TASS squarely placed the blame for their failure and other shortcomings on the Raikom:

The District Party Committee knew that the discussion of the draft Constitution on the collective farms was poorly organized, however upon dispatching the propagandists, no one in the Raikom thought it necessary to verify their work. Instructor Miliaev was supposed to corroborate the organization of the discussion on the collective farms, but this Miliaev has never been on a single collective farm. He waits for propagandists to return from the collective farms with travel vouchers, which, in turn, the chairmen of the rural soviet must certify. Many of the propagandists have not yet gone to the collective farms. In Iaransk, this important political work proceeds irresponsibly and bureaucratically. ${ }^{64}$

A similar report came from Regional Executive Committee organizational section instructors, who noted that in Slobodskoi raion, a great deal of effort had been put into the discussion, but nonetheless, local officials had failed to fulfill their duties. There were rural soviet workers who had not read the Constitution themselves, and in several rural soviets, discussion work had been foisted onto the heads of the collective farms. ${ }^{65}$ At the plenum of the Leninskii rural soviet, the decision was made "to obligate the chairmen of the collective farms to 'work up' the draft Constitution on their collective farms." As a result, on Bolshoi Shoromovskii collective farm and Eprinskii collective farm, the draft Constitution was not discussed. Likewise, in Stulovskii rural soviet, the draft Constitution was not discussed on two of the three collective farms that they checked.

A related failing that attracted the ire of the Regional Party Committee and Regional Executive Committee was the "working up" (проработка) of the draft Constitution by agitators and propagandists rather than the discussion (обсуждения) of its contents. Kraiispolkom instructor Lepekhin highlighted why the term "working up" was viewed in a negative light, as it "reeks of bureaucratism, and a formulaic approach to such a colossal task as the all union discussion of the draft Constitution." 66 "Working up" denoted paying only limited attention and devoting minimal time to the discussion of the draft Constitution, creating a short campaign-like overview rather than the in-depth discussion envisioned by central and regional authorities. For example, in Bogorodskii raion, on August 13, the District 
Executive Committee sent out a directive in which specific directions were given to "work up" the draft Constitution. As a result, a set term for the public discussion was established in the rural soviets, with the discussion to end by August $26 .{ }^{67}$ Similar events took place in Vladimirovskii rural soviet, Kotel'nicheskii raion, where, at the June 24 session of the presidium, it was suggested that the chairmen of the collective farms and members of the rural soviets "work up" the draft in general collective farm meetings. They were to present extracts from the meeting protocols to the rural soviet no later than June 26. In Kotel'nicheskii rural soviet, Kotel'nicheskii raion, the presidium of the rural soviet, discussed the draft Constitution on June 13 and resolved to "work it up" at the next plenum and on every collective farm; they set the deadline for June $25 .^{68}$ Even in the city of Kirov, a city Party committee report accused a number of leaders of trying to transform the discussion of the draft Constitution into a short-term campaign with limited meetings and general assemblies. ${ }^{69}$ This bureaucratic approach undermined the political importance that central leaders attached to the discussion and rendered any real participation impossible.

An unpublished report from Kirov TASS noted the adverse effects "working up" had on the discussion in Iaranskii raion. ${ }^{70}$ The report focused on a particular incident from Abramycheskii rural soviet involving comrade Baklanov, a Raikom plenum member. Comrade Baklanov organized one meeting to discuss the draft, which was poorly attended, and at that meeting the draft was adopted without any changes. After hosting this one meeting, "Baklanov obviously thought that his work was done, as he did not appear again on a single collective farm of that rural soviet." In addition to shirking his duties, he further undermined the implementation of the discussion by calling on others to follow his example. The reporter from Kirov TASS noted with disgust:

With sleight of hand, comrade Baklanov of Abramychevskii rural soviet suggested to the administrations of collective farms to quickly "examine" the draft Constitution on the collective farms. On many collective farms, chairmen and brigadiers read out the draft Constitution without discussion, moving on to the solution of everyday questions. For example, on the Stalin collective farm, in the protocol of the meeting of collective farmers, it is written: "Agenda: the Constitution-the fundamental law of the USSR, - the first question the 'examination' of constitutional law, Lecturer G. E. Tantarov. Decided: Constitutional law adopted. Pregnant women are freed from work for 2 months before and after the birth and are given working days with median pay." 71

Another example of the negative effects that "working up" the draft Constitution had on in-depth debate comes from Prosnitskii raion, where the public discussion became a formal "working up" that took the form 
of readings at all-kolkhoz and brigade meetings. The regional inspector claimed that,

such an organization of work made it so that no one had a knowledgeable opinion about any point of the draft Constitution, as a consequence of such banal formalism in the discussion well thought out additions and suggestions to the draft Constitution were scarce.

The suggestions that he found so objectionable included the guarantee of social security to collective farmers in case of the death of the head of house or inability to work, the guarantee of a yearly vacation to collective farmers, and free study and use of textbooks by students. ${ }^{72}$

Regional officials considered it unacceptable that raion and other local officials did not fulfill their duties. Such a failure demonstrated a lack of commitment to an important political task, but more importantly it lowered the quality of the discussion among the populace. Without strong reinforcement from those leading the discussion, meetings, suggestions, and additions to the draft Constitution tended to deviate from the prescribed narrative. Instead, suggestions came to focus on local and personal interests rather than the larger goal of mobilizing the populace in continued state-building efforts. Stephen Kotkin notes that many Soviet policies and programs often contained irreconcilable aspects that surfaced during attempts to implement them, as the implementation methods were often at odds with the stated goals of the programs and policies. Additionally, as these policies and programs formed part of ordinary and higher-up people's lives, their reactions, initiatives, and responses significantly influenced how those programs were implemented, circumvented, and changed in unforeseen ways. These functional problems and reinterpretations of policy on the periphery often led to results that were not entirely what the Bolshevik leadership had intended. ${ }^{73}$

Comrade Mironov, a delegate of the Regional Party Committee, noted the correlation between a poorly organized local discussion and the rise of local and personal suggestions to the draft:

The organization of the discussion of the draft Constitution was not strengthened by anyone. There were twenty members of the raion aktiv who were dispatched, [and] who conducted lectures. School workers and collective farmers made reports to the chairman of the collective farm. There were cases where in meetings of collective farmers, some literate collective farmer read the text of the Constitution and the discussion was limited to this. As a result of such a discussion, the majority of questions brought forward focused on equality with the working class, granting of benefits to elderly collective farmers, about vacations for collective farmers, about securing the eternal usage of garden plots, free vacations, medical aid, payment in money, not in kind or natural resources. Here, such a relationship to the organization of 
the discussion of the Constitution speaks of formal preparation. The protocols of the rural soviets are extraordinarily careless. For example in Kuznetskii artel', they wrote not a word about listening to the Constitution, but rather wrote that they listened to the newspaper and made a point to add about the establishment of a 7 hour working day and also a number of such occurrences. All of this says that in the raiispolkom, there are comrades who were sent for the discussion of the Constitution in the rural soviets, who don't display serious attitudes towards this question. ${ }^{74}$

Regional officials blamed district officials' failure to organize the discussion properly around the master narrative for the rise of "off-topic" suggestions. State and party officials never considered these suggestions, which as we shall see were among the most frequently proposed and actually reflected the desires of the populace. Likewise, in Lebiazhskii raion, where the District Executive Committee shifted the work on the discussion of the draft Constitution onto the shoulders of the chairmen of the rural soviets and collective farm chairmen, the regional officials blamed raion officials for "aberrant" suggestions, such as the proposal to organize legal peasant unions. ${ }^{75}$ A similar situation occurred at a meeting of the workers of the Slobodskoi forest production enterprise, where the draft Constitution was approved with changes to the following articles: to Article 11, include 100 percent of all office workers at the forest production enterprise, to Article 121, include technical education for 100 percent of all service workers and workers of the Slobodskoi forest production enterprise and the district forest products enterprise. ${ }^{76}$ Likewise, a regional Party committee report noted that in Slobodskoi raion, in a majority of cases the suggestions brought to the draft Constitution had an individual character, such as vacations for collective farmers and the granting of forests to the collective farm, which was attributed to poor leadership of the discussion. ${ }^{77}$

\section{Conclusion}

The discussion of the draft Constitution was supposed to mobilize the entire population of the USSR to study the text of the draft Constitution, its theoretical underpinnings, and the rights and duties conveyed to citizens, all within the context of continuing to build socialism. The central officials promulgated this narrative in the press and pushed local officials to create detailed lesson plans to meet these goals. In urban areas, where the Party and state had a strong presence and strong existing networks from which to draw organizers and agitational workers, the discussion of the draft Constitution proceeded more or less as the central officials envisioned it, although as discussed above, they were not problem-free. Study circles, meetings and radio listening sessions on the draft Constitution were organized and were relatively well-attended, although as noted above, there were 
quite a few exceptions. However, the local cadres tasked with implementing the discussion were often poorly trained and poorly prepared. On the collective farms, cadres' social standing often alienated them from their primarily rural audience. The discussion had a more pronounced campaign character in the countryside as well, which often led to a "working up" of the Constitution rather than a sustained discussion.

As additions to the draft Constitution began to trickle into regional and central offices, officials noted a large number of "individual" and "inappropriate" suggestions coming from the countryside. Such suggestions tended to focus on local and personal matters, like collective farm vacation days, rather than the grand scheme of socialist construction that central officials had sought to emphasize in their lesson plans and articles published in the central press. Raion officials' organizational failures were blamed for the prominence of such suggestions. Central expectations were not and probably could not have been fulfilled in the implementation of the discussion of the draft Constitution by the local authorities tasked with carrying out their directives. The state had overreached and, by opening up the draft Constitution for discussion, it received responses that deviated wildly from its expectations. Unable or unwilling to concede that these suggestions may have been honest representations of popular opinion, regional and central authorities blamed raion officials. And, as we shall see in Chapter 6, those authorities used the discussion of the draft Constitution to have many local officials removed from office by their constituents.

\section{Notes}

1 GAKO, f. R-2168, op. 1, d. 474, 1. 24.

2 Unfortunately, the document does not provide any clues as to the identity of these correspondence students, simply referring to them as заочники. These materials are housed in the archives of the City Committee of the $\operatorname{VKP}(b)$ in Kirov. GASPI KO, f. 1293, op. 2, d. 43, 11. 10-13.

3 GASPI KO, f. 1255, op. 2, d. 20, 1. 250.

4 GASPI KO, f. 1293, op. 2, d. 43, 1. 10.

5 Bolshevik, 12, (1936), 114-126.

6 Bolshevik, 11, (1936), 8-29.

7 GASPI KO, f. 1293, op. 2, d. 43, 11. 11-12.

8 Pravda, June 16, 1936, 1.

9 GASPI KO, f. 1293, op. 2, d. 43, 1. 12.

10 Pravda, June 16, 1936, 1.

11 Izvestiia, June 17, 1936, 1.

12 Izvestiia, June 23, 1936, 1.

13 The only break from this dialogue was the section on the "characteristic trait of the draft as an instrument of peace and freedom," which seemed to almost be an afterthought. The leaders of study circles were informed that "it [was] necessary to particularly underline the essence of Article 49 (on the duties of the Presidium of the Supreme Soviet), which provides that only in cases when there is an assault on the USSR, the Presidium of the Supreme Soviet can declare a state of war. This formulation flows entirely from Stalin's statement: 
We don't want one row of foreign soil, but we will not give one verst of our land to anyone." GASPI KO, f. 1293, op. 2 d. 43, 1. 13.

14 GASPI KO, f. 1255, op. 2, d. 20, 1. 250.

15 GASPI KO, f. 1255, op. 2, d. 224, 1. 59.

16 GAKO, f. R-2168, op. 1, d. 472, 1. 23.

17 GAKO, f. 2168, op. 1, d. 472, 1. 23.

18 GASPI KO, f. 1255 , op. 2, d. 224, 1. 59.

19 GASPI KO, f. 1255 , op. 2, d. 224, 1. 38.

20 Roberta T. Manning, "Government in the Soviet Countryside in the Stalinist 1930s: The Case of Belyi Raion," The Carl Beck Papers in Russian and Eastern European Studies (University of Pittsburgh Center for Russian and East European Studies, 1984), 10.

21 GAKO, f. 2168, op. 1, d. 472, 1. 42.

22 GAKO, f. 2168, op. 1, d. 472, 1. 42.

23 GASPI KO, f. 1255, op. 2, d. 224, 1. 9.

24 Manning, 45-46.

25 GAKO, f. 2168, op. 1, d. 472, 11. 1-2.

26 GASPI KO, f. 988, op. 1, d. 202, 11. 37-39.

27 GAKO, f. R-2168, op. 1, d. 472, 11. 9-10.

28 Mary Buckley, Mobilizing Stalin's Peasants: Heroines and Heroes of Stalin's Fields (Ronan and Littlefield Publishers: New York, 2006), 9.

29 GAKO, f. R-2168, op. 1, d. 474, 1. 32; a similar method of discussion was described in Vozhgal'skii raion as well: GASPI KO, f. 1255, op. 2, d. 224, 1. 1.

30 GAKO, f. R-2168, op. 1, d. 474, 1. 32.

31 GASPI KO, f. 1255 , op. 2, d. 224, 1. 6.

32 GASPI KO, f. 1255 , op. 2, d. 224, 1. 8.

33 GASPI KO, f. 1255 , op. 2, d. 224, 1. 6.

34 GASPI KO, f. 1255 , op. 2, d. 224, 1. 9.

35 GASPI KO, f. 1255, op. 2, d. 224, 1. 30. Similar large-scale radio lectures were organized in Svechinvskii raion (GASPI KO, f. 1255, op. 2, d. 224, 1. 4) and Shabalinskii raion (GAKO, f. R-2168, op.1, d. 472, 1. 42).

36 GAKO, f. R-2168, op. 1, d. 472, 1. 9.

37 GAKO, f. R-2168, op. 1, d. 474, 1. 362.

38 GASPI KO, f. 1255 , op. 2, d. 224, 1. 9.

39 GASPI KO, f. 1255, op. 2, d. 224, 1. 59.

40 Kirovskaia Pravda, August 17, 1936, 3.

41 Punctuation in the original.

42 Kirovskaia Pravda, September 9, 1936, 2.

43 Kirovskaia Pravda, October 29, 1936, 1.

44 Kirovskaia Pravda, October 29, 1936, 1.

45 Kirovskaia Pravda, October 29, 1936, 1.

46 Kirovskaia Pravda, October 29, 1936, 1.

47 GASPI KO, f. 1255, op. 2, d. 224, 1. 9.

48 GASPI KO, f. 1255 , op. 2, d. 224, 1. 9.

49 GAKO, f. R-2168, op. 1, d. 474, 1. 340.

50 The numbers here are likely inexact. Most of the collective farms did not list a specific number of meetings but provided participation information, indicating at least one meeting was conducted. I assigned those a value of one. Seventy-nine additional collective farms were listed on this chart but no other information was provided, so perhaps meetings did not occur there or no information was provided to the Raikom. GASPI KO, f. 988, op. 1, d. 202, 11. $1-23$.

51 GASPI KO, f. 988, op.1, d. 202, 1l. 1-23. 
52 We shall address these so-called "irrelevant" suggestions further on in Chapter 3, GASPI KO, f. 988, op. 1, d. 202 1. 31.

53 GASPI KO, f. 988, op. 1, d. 202, 1. 40.

54 GASPI KO, f. 988, op. 1, d. 202, 1. 40.

55 GASPI KO, f. 988, op. 1, d. 202, 1. 32.

56 GASPI KO, f. 1255, op. 2, d. 224, 1. 59.

57 GASPI KO, f. 1293, op. 2, d. 39, 1. 63.

58 The Educational technical school equipment combine (комбинат учебнотехнического школьного оборудования).

59 GASPI KO, f. 1293, op. 2, d. 43, 11. 16-17.

60 GASPI KO, f. 1293, op. 2, d. 43, 1. 24.

61 GASPI KO, f. 1293, op. 2, d. 43, 1l. 91-92.

62 GAKO, f. R-2168, op. 1, d. 472, 1. 2.

63 GASPI KO, f. 6777 , op. 3, d. 87, 1l. 1-2.

64 GASPI KO, f. 6777, op. 3, d. 87, 11. 1-2.

65 GAKO, f. 2168, op. 1, d. 472, 11. 1-2.

66 GAKO, f. R-2168, op. 1, d. 472, 1. 72.

67 GASPI KO, f. 1255, op. 2, d. 394, 11. 114-117.

68 GASPI KO, f. 1255, op. 2, d. 394, 1l. 114-117.

69 GASPI KO, f. 1293, op. 2, d. 43 1l. 18-38.

70 GASPI KO, f. 6777, op. 3, d. 87, 1l. 1-2.

71 GASPI KO, f. 6777, op. 3, d. 87, 1l. 1-2.

72 GAKO, f. R-2168, op. 1, d. 472, 1l. 54, 56.

73 Kotkin, 21-22.

74 GASPI KO, f. 1255, op. 2, d. 394, 1. 6.

75 GASPI KO, f. 1255 , op. 2, d. 394, ll. 114-117.

76 GAKO, f. R-2168, op. 1, d. 472, 1. 1.

77 GASPI KO, f. 1255, op. 2, d. 394, 1l. 262-266. 


\section{Validators of socialist victory The discussion in the local press}

The popular discussion of the draft Constitution was supposed to unite the country in the pursuit of a common goal: the construction of socialism. What it succeeded in doing, however, was highlighting fractures in Soviet society and the dissonance between the central leadership's state-building goals and the citizens' local and personal focus. In the Kirov region, the popular responses reflected the socioeconomic divisions of the region, with most of the suggestions coming from rural inhabitants and focusing on issues that concerned them. Their suggestions demonstrated both the continuity between rural concerns in the pre-revolutionary period and under Soviet rule and served to highlight the changes in the mentality that 20 years of Soviet power had wrought. However, the goals of Kirov's primarily rural inhabitants stand in sharp contrast with the more publicized suggestions made by the better-educated and more-integrated urban dwellers who were much more likely to embrace the central leadership's statebuilding narrative than their rural counterparts. The popular discussion of the draft Constitution revealed that the heavily promoted and publicized state-building goals of the central party and state leadership were internalized by only a small stratum of citizens, most of whom were members of the urban and working elite, while the vast, rural majority of the population co-opted and used official language to promote their own local and personal aims.

The contrast between the rural and urban discussion can be best seen by comparing the discussion of the draft Constitution as it was presented in the local newspapers with the reports compiled by district and regional officials from the popular discussion at large. As mentioned in the previous chapter, the central state and Party officials tried to guide and shape the discussion by urging local leaders to emphasize state-building aspects of the draft and criticizing discussion organizers when participants made many personal or locally oriented suggestions, a function for which Soviet newspapers were perfectly suited. Newspapers relied heavily on letters and materials from privileged groups, such as Party members, Stakhanovites, order winners, collective farm chairpeople, and urban workers. Such people, though perhaps not representative of urban dwellers and intellectuals 
as a whole, tended to have a broader worldview and to conform more to the messages presented in official publications and in lesson plans. ${ }^{1}$ The popular discussion highlighted the stark divide between this small, yet active, educated, and privileged population, which had been successfully integrated into Soviet society, and the vast majority of the population, who focused on local and personal matters and were more isolated from state power. $^{2}$

The Party and the Soviet state had always been very conscious of public opinion and experimented with various ways of eliciting public opinion and support. As Jeremy Hicks notes, by 1922, letter writing had become institutionalized as a source of information and a means of encouraging participation. ${ }^{3}$ The state sought to harness this enthusiasm and to turn public opinion into a force for establishing institutional forms of control, particularly in the periphery, where the local Party and state apparatus seemed at times beyond the center's governance. In the late 1920s and early 1930s, the workers' and peasants' correspondents movement took on the roles of the eyes and ears of the Party in the countryside, reporting on local officials who were not fulfilling their duties, on the success and failure of various campaigns, and other issues. Matthew Lenoe notes that for the authors, letters were a channel of petitions to those with all types of powers: asking for a job, expressing opinions for or against the Party line, settling private disputes, or seeking redress for injustice. ${ }^{4}$

The local press was an important forum for the popular discussion of the draft Constitution, as it provided articles on the basic rights and democratic principles ensconced in the draft as well as letters from the inhabitants of the Kirov region about these rights and principles. The press reflected the center's focus on creating enduring forms of administration, military power, revenue extraction, and economic development, and tied letter writers' personal achievements or concerns to the master state-building narrative in a way not seen in public discussion in the countryside. Of the approximately 180 letters and suggestions printed in the main regional newspaper, Kirovskaia Pravda, most came from the urban dwellers or privileged rural workers: engineers, workers, housewives, political figures, brigadiers, doctors, Stakhanovites, collective farm leaders, and tractor drivers. ${ }^{5}$ These correspondents represented the strata of society that benefited the most from Soviet power, and as a result they were better educated and more supportive of the Party and other state groups.

Their position as beneficiaries of the Soviet regime and believers in Soviet ideology is reflected in the tone and focus of their letters. Many letters focused on the benefits and opportunities that Soviet citizenship had provided for them and how they would try to repay the regime with even greater labor outputs. One such letter, entitled, "Women in the workplace," was written by N. Sumaneeva, an award-winning collective farmer from the Rosa Luxemburg collective farm. Sumaneeva's letter describes how happy she was to hear ${ }^{6}$ the text of the new draft Constitution, which had "Stalinist 
concern for the people embedded in it from beginning to end."7 She enumerates the tangible and intangible benefits the Soviet regime brought her:

"I was illiterate, lived poorly and was dressed badly. Now I have become literate, have a house, a radio, a portable gramophone, a bicycle and good clothing. The government greatly values my work. In 1935, I was awarded the order 'Mark of Honor' for Stakhanovite flax processing work.

She made clear that she felt like a valued and honored member of society who lived comfortably and was rewarded for her hard work. But, according to Sumaneeva, these benefits were not just for her, they extended to all women, thanks to the new draft Constitution, which guaranteed equal rights, equal pay for equal work, and the right to vote and hold office. In gratitude to the Soviet state, Sumaneeva and her fellow collective farm women pledged to give back:

This wonderful Stalinist policy makes me and the collective farm women of my work team happy and makes us wish to incessantly struggle for the attainment of the greatest flax harvest in the world. Thank you comrade Stalin for a good happy life. ${ }^{8}$

Sumaneeva's letter is representative of much of the correspondence reprinted in Kirovskaia Pravda. Most of the writers had experienced significant improvements in their lives. They had either risen to positions of prominence in economic or political areas, had seen increases in standards of living, or had new educational opportunities. All seemed to earnestly believe in the Soviet system. They became "validators" for the regime. For example, Matvei Tubylov, a member of the rural Soviet, discussed how his parents could not vote during the Tsarist period, but he had been elected at the age of 24 to the rural Soviet. He noted how his family now had livestock and he owned a bicycle. ${ }^{9}$ Soviet power had brought his family the possibility of political participation and an improved lifestyle. A similar letter came from section leader, A. P. Smertina, on the "New Construction" collective farm. She noted that, in the past, she had been an illiterate peasant; now she was a citizen with full rights and a Stakhanovite worker on the collective farm. The state offered her unique opportunities to participate in the civic life of the country as a Stakhanovite. She talked about how she would never forget her participation in the 2nd Congress of Stakhanovite-Shock Workers in 1934, where "together with our beloved Leaders [she] participated in the making of regulations on collective farm life." Smertina also focused on how the Soviet state and the new Constitution provided opportunities for her children. She was the mother of nine children, eight of whom were in school, and she praised the Constitution for the right to education, which she believed would open many doors for them. ${ }^{10}$ 
Like Tubylov and Smertina, many of the validators' letters focused on how the new rights embodied in the draft Constitution resonated in their lives. In a letter originally entitled, "The Voice of an Elderly Man," I. F Men'shkov, the 65-year-old accountant at the Kotel'nich mental hospital, explained that he was very pleased to see Article 120 about material aid in the draft Constitution. However, he considered it necessary to make some changes, specifically to lower the age for receiving a pension to 60 and have the size of the pension be determined by the number of years worked. Above all, he considered it important to establish personal pensions for those workers, like himself, who had worked more than 40 years. ${ }^{11}$ Kopanev, a controller for the mechanical section of KUTShO, ${ }^{12}$ was another person whose life had been transformed by the benefits that the Soviet state provided for its citizens. He suffered from tuberculosis and was sent to a health resort for medical treatment, which was a right guaranteed to him under Article 120 of the draft Constitution. Additionally, the state educated his children for free, and every year his children relaxed at a Pioneer camp. Kopanev stated that he was waiting with impatience for the approval of the new Constitution, which codified these rights and expressed the state's concern for its people. ${ }^{13}$ These personal stories served to concretely illustrate how socialism had transformed the lives of those who embraced it and worked hard.

Even a formerly disenfranchised member of society used the constitutional discussion to demonstrate how the Soviet state had improved his life, despite the disadvantages that he still faced. Seventy-year-old Filipp Borodin, a person formerly deprived of voting rights, and as a result, liable for individual taxes, embraced Soviet power. He supported the Soviet system because it had re-educated him and provided opportunities for his children to live off the fruits of their own labor. Borodin had become a shock worker on the Stakhanovite work team in his collective farm and had subscribed to a 50 ruble loan to the state. ${ }^{14}$ This man's experience demonstrated how difficult it was to compartmentalize Soviet citizens based on one aspect of their identity. As a formerly disenfranchised person, it would stand to reason that Borodin would be anti-Soviet; instead, he embraced the positive changes in his life and became a Soviet supporter. While this letter undoubtedly served propagandistic functions, such as demonstrating that many of the formerly disenfranchised had reformed, it also served to illustrate that individual decisions and situations often served to drive state-citizen relations in the USSR.

The majority of the letters published in Kirovskaia Pravda served to validate the state's assertions that it had provided spiritually and materially for its citizens, and that many of these gains were codified in the new draft constitution. ${ }^{15} \mathrm{~A}$ great number of the authors responded by asserting that they would work harder for the state in appreciation for their new rights and privileges. Letters to Kirovskaia Pravda frequently dealt with the theme of working harder as an expression of appreciation. In the article, "The 
Constitution Restored my Youth," 57-year-old Stepan Dorofaevich Iuferov, a brigadier and order winner on the "Science" collective farm in Shabalinskii raion, was particularly impressed with how the Constitution gave laborers the right to free speech and press, which he thought was only possible in the USSR. Iuferov also noted that the draft Constitution gave laborers voting rights, the right to be elected and to develop their talents. He had worked for five years as a brigadier and stated that the Constitution has given him new strength to work, despite his advancing age. ${ }^{16}$ Taisiia Nikolaevna Shvrina, a tractor driver from the 13th group at the Bel'koi MTS, echoed Iuferov's sentiments. She wanted to respond to the draft Constitution with even greater productive labor. She saw the Constitution as a mirror of Soviet life, reflecting all of the advancements of socialism, which gave the ability for laborers to work honestly and have a happy life. In recognition of this fact, she and her husband, who was also a tractor driver, vowed to work harder to more quickly develop the motherland. ${ }^{17}$

This desire to work ever harder for the benevolent socialist state was reflected in many of the letters that were selected for publication. In "The Wonderful Document of the Stalinist Era," A. Gusak, an order winner and chairman of the Voroshilov stud farm, wrote:

Imbued with Stalinist concern for people, the new Constitution motivates the laborers to work better; part 10 of the draft Constitution enumerates the rights and duties of citizens. This Constitution ensures [that] everyone has honorable work and many opportunities for a prosperous and cultured life, cultural growth, and for the complete utilization of their capabilities. But the Constitution places a great and honorable duty on citizens. It is a duty we must piously fulfill. We must respond to this appeal with enthusiasm, be vigilant in the struggle for developing the material standards of the country through increased productive labor. ${ }^{18}$

Another letter, this time from the factory director of Izhstal' zavod, the Izhevsk steel factory, proclaimed that:

The new Stalinist Constitution is a testimonial to the final victory of socialism. The Constitution is the new stimulus for the further development of the country, the ascension of industrial labor, and the growth of laborers' welfare. The Izhstal'zavod collective of workers and service workers will work harder. The Constitution inspires us to work better; struggling for greater industrial output, for the improvement of product quality and for strengthening the might of our country. ${ }^{19}$

Such testimonials printed in Kirovskaia Pravda underscored the achievements of socialism as codified in the draft Constitution, validated that life had gotten better under Soviet power, and asserted that these achievements 
were only possible because of the communist principles and class-based focus of the regime. This reciprocal relationship served to highlight the notion that rights were neither natural nor inalienable. While protected by state law, these rights came from the state, not from an immutable outside source. Hence, they should therefore be used to further the state-building goals of the government.

Those who had their letters published represented a privileged stratum of Soviet society that had seen dramatic material and social gains since the regime assumed power. There is no reason to assume that those who wrote the letters did not believe that the Soviet system had made their life better. However, these people were not representative of Soviet society as a whole. These letters better served as a continuation of the central narrative of the discussion, emphasizing the gains of socialism that were codified in the Constitution and the obligations citizens had towards the state in return for their rights and improved quality of life, rather than a reflection of the questions and concerns of the majority of citizens. ${ }^{20}$

The divergence in the interests of the state and the citizens of the Kirov region is exemplified by a report from the Regional Executive Committee to the Central Executive Committee in Moscow. The report notes that the three most popular suggestions in the Kirov region were:

1 Don't give priests the right to vote.

2 Make collective farmers equal to workers in the allocation of material aid in old age and sickness and access to resorts and rest houses.

3 Allow the arrest of malicious hooligans, bandits, and destroyers of socialist property without the sanction of the procurator. ${ }^{21}$

These suggestions ran counter to the state's new policies as elucidated in the draft Constitution. Central authorities had promoted the expansion of the franchise to include even "former people," such as the abovementioned Borodin, the introduction of habeas corpus, and a codified regulated legal system as key policies for extending Soviet democracy. Stalin himself added the distinct delineation between the workers and the peasants in both name and rights to the Constitution and considered these distinct class divisions to be the foundation of the Soviet state. However, for many people in the Kirov region, the state's new policies and focus were viewed as disadvantageous, even harmful, to them. The grateful, happy state-building narrative represented in the letters published in newspapers was never widely accepted by the citizens of the USSR. The persistence of suggestions focused on individual problems and daily life did not represent a failure of explanatory work on the part of the district executive and party committees, or newspaper editors. Instead, this dissonance in the discussion represented a true divergence of interests between the central leadership and its citizens that no amount of explanatory work could reconcile. 


\section{Notes}

1 This small group did not necessarily represent the majority of urbanites or intellectuals, but they provided the backbone of support for the constitution. There is no reason to believe their support of the Soviet state was not genuine, as many had seen serious improvements in their living conditions.

2 Sarah Davis makes note of this dichotomy in her work, Popular Opinion in Stalin's Russia, 102-112. She notes that the rights and freedoms that were promoted during the discussion of the draft Constitution often did not resonate with the masses of Soviet citizens. She further notes that much of the language on freedom and rights had been restricted to circles of intelligentsia up until that point, and as a result, many people either outright rejected these new rights or rejected the constitution as untenable in the USSR. She also argues that the introduction of a discussion of rights led to many of the "inappropriate suggestions" that I discuss later in this chapter and Chapter 5, such as equal vacations for workers and peasants, peasant unions, and even alternate parties.

3 Jeremy Hicks, "From Conduits to Commanders: Shifting Views of Workers Correspondents, 1924-26," Revolutionary Russia, Vol. 19, No.2 (December, 2006), 131-149.

4 Matthew Lenoe, "Letter Writing and the State: Reader Correspondence with Newspapers as a Source for Early Soviet History," Cashiers du Monde Russe: Russie, Empire Russe, Union Sovietique, Etats Independants, Vol. 40, No. 1-2 (1999), 139-170.

5 The full list includes: five heads of sections in manufacturing enterprises, 11 order winners, four engineers, three housewives, 14 Stakhanovites, 16 workers, nine students, eight brigadiers, three heads of agricultural artely, a head chef, three immigrant workers, a financial planner, an artist of a republic, a member of the Krai court, 14 individual collective farmers, two groups of collective farmers, a master barber, four doctors, six current or former Red Army soldiers, a political worker, a member of the city Soviet, three tractor drivers, a chief swine herder, two shock workers, two accountants, two agronomists, three pipe fitters, six pensioners, a Kirov city judge, three Regional Executive Committee members, three heads of collective farms, an editor of a collective farm newspaper, a factory director, a section leader, two rural Soviet members, a Kraikom member, a machinist, a club director, and a secretary.

6 Many people went to public readings of the draft constitution. Therefore, they would have heard, rather than read, the draft constitution.

7 Kirovskaia Pravda, July 2, 1936, 2.

8 Kirovskaia Pravda, July 2, 1936, 2.

9 Kirovskaia Pravda, July 21, 1936, 3.

10 Kirovskaia Pravda, July 17, 1936, 3.

11 GARF, f. R-3316, op. 41, d. 83, 1. 28. This letter was printed in Kirovskaia Pravda on July 9 under the heading of "about pensions," though an original copy exists in GARF and is dated November 29, 1936.

12 The Educational technical school equipment combine (комбинат учебнотехнического школьного оборудования).

13 Kirovskaia Pravda, July 5, 1936, 2.

14 GAKO, f. R-2168, op. 1, d. 474, 1. 26.

15 Kirovskaia Pravda may have censored what it published, but unfortunately, I was able to find very few unpublished letters about the draft Constitution in the archives in Kirov. I did find a handful in GARF, one of which had been published in Kirovskaia Pravda.

16 Kirovskaia Pravda, July 4, 1936, 2. 
17 Kirovskaia Pravda, July 4, 1936, 2.

18 Kirovskaia Pravda, July 10, 1936, 2.

19 Kirovskaia Pravda, July 11, 1936, 3.

20 For more information on the disparity between public and private narratives, see: Jochen Hellbeck, Revolution on My Mind: Writing a Diary under Stalin (Cambridge, Mass: Harvard University Press, 2006).

21 GASPI KO, f. 1293, op. 2, d. 43, 1. 155. This whole report is reproduced in GAKO, f. R-2168, op. 1, d. 473, 1. 29. 


\section{Popular voices Interpreting citizens' rights and duties}

The Party and government appealed to the people on such an important question, allowing them to express their opinions through corrections to the draft Constitution, demonstrating to the capitalist world that the Party and government, in conjunction with the people of our country, aspire towards one general goal and they move on the same path towards that goal." 1

from a report on the discussion made by workers of the Regional Forest Administration

The state and the Party sought to use the public discussion to rally national support for various state-building projects. However, popular suggestions often deviated from this state-building narrative and the tailored reporting of popular responses to the draft Constitution in local and regional newspapers. Citizens of the USSR, particularly those from rural areas, focused on securing rights and privileges from the central government often related to improving their daily lives. J. Arch Getty views the popularity of "bread and butter" suggestions as pragmatic citizens addressing the aspects of the Constitution that affected their everyday lives while ignoring such topics as freedom of speech, which they regarded as irrelevant. ${ }^{2}$ Certainly pragmatism underpinned many of the popular suggestions, but this work refutes Getty's conclusion that such down-to-earth suggestions implied the ongoing continued existence of a village mentality and an ambiguous attitude towards the Soviet state as a whole. ${ }^{3}$ As the following chapter demonstrates, Soviet citizens had strongly developed opinions about the role of the state. By and large, the inhabitants of the Kirov region bought into the notion of a social contract, that in exchange for their labor on various state-building projects, the state was obligated to provide for them, though what type of support they thought they should receive was often informed by the individual discussant's lived experience and current needs. In contrast, Sarah Davies believes that the vast propaganda campaign promoting the draft Constitution exposed citizens to democratic concepts they had never before considered, made an explicit contrast between the ideal (the Constitution) and reality (everyday Soviet experience), and paradoxically 
stimulated popular criticism of the Soviet regime. ${ }^{4}$ What this study demonstrates is that many of the democratic additions to the draft, such as expanded voter franchise and habeas corpus, were highly unpopular and were often rejected in favor of tighter control and stability, a trend that has echoes in Putin's popularity, despite accusations of authoritarianism. Both Getty and Davies see the Constitution as a catalyst for unanticipated misinterpretation of the regime's intentions and focus on how this caused the Party and state leadership to rethink its position leading up to the election campaign of 1937, which while important, overlooks the value of the discussion itself. ${ }^{5}$ This work uses the additions, corrections, and suggestions to the draft Constitution as a window for viewing the issues that concerned citizens, how they conceived of the socialist social contract, and how they defined political accountability.

Popular suggestions from the Kirov region are ideal for studying the public discussion on a regional scale. The submissions from the Kirov region were reflective of larger countrywide trends, making the Kirov region a good representative of the USSR as a whole. As of November 15, 1936, 43,427 suggestions from across the USSR had been compiled and tabulated by the Organizational Section of the Central Executive Committee. Of the 146 articles of the Constitution, only nine articles had received more than a thousand individual suggestions. Those were as follows: Article 8, pertaining to land usage $(1,026)$; Article 109, concerning the election of people's courts (1,551); Article 119, relating to the right to rest $(4,060)$; Article 120, pertaining to material security and pensions (4,960); Article 121, on education (3,400); Article 127, concerning habeas corpus (3,218); Article 132, on military service (2,416); Article 135, about voting rights (4,716); and Article 142 , pertaining to deputies' responsibility to their constituents $(1,048)$. (For the full text of articles, see Appendix). ${ }^{6}$ In Kirov, the six articles that received the most suggestions were: Article 8 (263), Article 119 (381), Article 120 (476), Article 121 (259), Article 127 (223), and Article 135 (244). ${ }^{7}$ Articles 109,132 , and 142 had a more modest number of suggestions, but nonetheless remained important in the Kirov region. From this it can clearly be seen that Kirov serves as an excellent model for evaluating the USSR.

During the popular discussion in the Kirov region, certain segments of the population were more vocal than others about the issues that touched their lives. Individuals rather than groups and men rather than women contributed more suggestions to the draft. From a total of 3,182 suggestions, 2,071 were suggested by individuals (65.1 percent of the total), while 1,111 were suggested by groups ( 34.9 percent of the total). This suggests that the group mentality characteristic of village petitions was gradually being replaced by a sense of individuality. Of the 2,071 individual suggestions, 2,056 of them listed the gender of the person making the suggestion: 1,775 were male, and 281 were female. Put another way, individual women only made 13.7 percent of the suggestions while 86.3 percent were made by men. Women tended to be more likely to make suggestions about traditionally feminine 
topics such as child-rearing and household concerns. This tendency, coupled with the low number of individual women's suggestions, indicates the persistence of a strong patriarchy. Traditional patriarchal values were reinforced by the state. Despite early Soviet efforts to change traditional gender roles, Stalin supported those roles as a way to increase stability during the upheaval of the First Five-Year Plan and as a way to increase the Soviet Union's population.

Language appeared to be another factor that may have limited certain groups' participation in the Constitutional discussion. Some of the questions asked during the discussion reflected the fact that the language and concepts used by state and Party representatives to explain the draft Constitution were sometimes confusing and beyond the experience of the discussants. One of the most telling examples came from Omutninskii raion, where the collective farmers were interested in what the words "race," "chamber," and "constitution" meant. ${ }^{8}$ These questions tended to arise in rural areas, where the state and Party had the least influence and educational levels were lower. They not only reflected the low political and civic educational levels in the countryside, they also exemplified part of the gap between the city and the country. In the city, the dialogue tended to be more sophisticated and politically aware, more reflective of the discussion of the draft Constitution in Kirovskaia Pravda. The questions that the collective farmers posed during the discussion provide a snapshot of the levels of political illiteracy in the countryside. However, political illiteracy is not to be confused with political impotence or lack of agency. While the rural population at one level may have been politically illiterate about terms, structures, etc., they were still savvy enough to ask penetrating questions. ${ }^{9}$ As illustrated in the case of the collective famers' challenge to the road committee in Zuevka raion, discussed in Chapter 2, rural people were often able to incorporate the language and laws of the state into their arguments against proposed policies. Much of their knowledge emanated from lived experience, which helps to explain why the rural population was more politically engaged about things of immediate importance.

As a result, the most pressing themes brought up during the discussion of the draft Constitution were citizens' rights and responsibilities and how they would be realized in daily life. In Kirov, the participants in the discussion focused on including or excluding certain groups of people from citizenship rights and/or the corresponding benefits. The participants used the rhetorical and political tools that the state had given them to agitate for their interests in order to change state policy and were politically active and engaged in a dialogue with the state. Education, military service, vacation time, pensions, land usage, and property ownership were the primary spheres where people from various sectors of society struggled to define citizenship and who was entitled to the rights and benefits of citizenship. ${ }^{10}$

In Viatka, local educational initiatives had roots in the pre-revolutionary zemstvos. The peasants had long valued basic education as a way to 
improve their lives. After the revolution, the Soviet state had assumed the task of developing and administering the educational system, and the draft Constitution established education as a fundamental right. While the interests of the state and the inhabitants of the Kirov region were at odds on some issues, on the matter of schooling, their interests coincided. Bettereducated people were better citizens and builders of socialism and had more opportunities for improving the quality of their lives.

Access to education was of particular concern to Kirovites. In total, they made 259 suggestions to Article 121, which dealt with education. Onefifth (51) of the suggestions focused on removing or raising the age limit for matriculation into higher educational institutions. While there were undoubtedly many reasons for such suggestions, the limited educational opportunities available to most people, particularly rural inhabitants during the Tsarist period, meant that many older people now wished to have access to educational opportunities that they had been previously denied. ${ }^{11}$

Access to school supplies, books, and other educational materials was another concern. Officials focused on how the Soviet Constitution provided the material means for the realization of citizenship rights like the freedom of press, and participants in the discussion argued that the material means to effectively utilize their right to education should be guaranteed by the state as well. One-third (86) of the suggestions to Article 121 dealt with providing students, in various circumstances, with school supplies or textbooks at the state's expense. Some people suggested providing only for needy students. For example, Iosif Andreevich Obatin suggested providing aid for elementary and junior high school students, particularly children having poor material conditions, such as dependents of single mothers who had many children. ${ }^{12}$ Other participants, such as Ivan Sergeevich Ustiugov, suggested giving free educational supplies and writing accessories to all school students. ${ }^{13}$ Fairness, in this case equal access to education, was of primary concern to the citizens of the Kirov region.

Fairness also motivated most of the suggestions to Article 132 about military service. Kirov residents' main foci were the integration of women into the armed services and the changing of the word "povinost" (obligation), which had Tsarist overtones. Article 132 lauded service in the Red Army as the honorable duty of every citizen of the USSR, but the Party and state remained ambiguous about the role of women in the armed services. Many inhabitants of the Kirov region wanted to have the role of women in the military clarified. Almost half (45.6 percent) of the total suggestions concentrated on the inclusion of women in military service. Two main reasons were given for the inclusion of women: distributing responsibilities fairly between men and women who were equal citizens under the law, and the need to defend the USSR in case of war. Stolbova, a female collective farmer, suggested that military service in the Red Army should be an honorable commitment for both male and female citizens of the USSR. ${ }^{14}$ Mesheriakov, a Party organizer, felt that for women to have completely equal rights with 
men, "it is necessary for women to also be granted the honorable duty of service in the ranks of the Worker and Peasants' Red Army." ${ }^{15}$ Bogomolov, a Party member, felt that since men and women have equal rights, women should do military service on equal terms with men. He felt that women could be effective partisans as they also could own a rifle and defend their motherland. ${ }^{16}$

But not all participants felt that women should be drafted into the army. A citizen from the Mininskii voting district, Darovskoi raion, suggested because "women have equal rights here, they may be beneficial to the army in the medical corps." ${ }^{17}$ Other participants in the discussion suggested that women serve only as volunteers in the Red Army, ${ }^{18}$ but that they should have to undergo compulsory military training to defend their motherland. ${ }^{19}$ So while the exact terms of service were not agreed upon, many of the inhabitants of the Kirov region felt that women, as citizens of the USSR, were obligated to and capable of defending their country. Timing was undoubtedly an important factor behind such suggestions. 1936 saw the rapid expansion of the Spanish Civil War, as well as growing threats from Japan and Germany, all of which received much press coverage in the USSR. But these suggestions may also reflect an increasing acceptance of women's equality and an appeal to the sense of fairness that seems ingrained in the psyche of many participants. It is doubtful that state and Party officials encouraged the inclusion of women in the armed forces. Even during World War II, the state accepted women's participation on the front but maintained a legal ambivalence about the role of women in the military and demobilized female units following the war, returning the Soviet military to a man's domain and women to the role of support staff.

Many Soviet citizens took particular pride in serving their country, and nowhere was this pride more evident than in suggestions to rephrase Article 132. The word used in the draft Constitution, "povinost," had roots in Tsarist society and implied a forced obligation. Many Soviet citizens had come to believe service to the new state was an honor and that the wording of the draft Constitution should reflect this. Aleksei Trushchkov, a collective farmer, explained the significance that this word had to Soviet citizens. He noted that,

in the imperialist war, I was at the front bearing military duty "povinost". My son Kostia and I quickly joined the Red Army. Service for him was a point of honor not an obligation, not "povinost", correct the article where it says that for us military obligation is "povinost"change the word to service "sluzhba"."

Approximately one-quarter (24 percent) of the total suggestions to Article 132 dealt with changing the article's wording, expressing citizens' pride in the state that they helped construct and for which many of them had already fought and bled. 
The sense of fairness that dominated suggestions about education and military service pervaded the whole of the discussion, making the different rights afforded to workers and peasants by far the most contentious issue raised during the discussion. These different rights had a profound impact on the quality of citizens' daily life and also violated their sense of equality. If both workers and peasants were builders of socialism, many participants believed they should have the same rights and responsibilities. This was reflected in the constitutional discussion where, for example, peasants were strongly opposed to the wording of Article 1 because the use of the words "workers and peasants," rather than the more encompassing term, "laborers" (трудящихся), implied a separation between workers and peasants that limited certain rights for the peasantry. Of the 64 total suggestions made to Article 1 in the Kirov region, 46 (71.9 percent) asked to change the term "workers and peasants" to the term "laborers," which had been used in the two earlier constitutions, so that the peasantry could be afforded the same benefits as workers.

Given the many connections between town and country in Kirov, rural inhabitants of the region were aware of the differences in lifestyle and the small luxuries afforded to urban dwellers. As the collective farmers saw it, workers had a limited number of hours a day when they could be compelled to work, they paid lower tax rates, and they had more access to manufactured goods. In comparison, collective farmers worked long hours, often more than 12 hours at a time, without weekends or holidays. They questioned why, if all citizens had equal rights, did they work longer and receive fewer benefits than the workers. For example, in Alferovskii agricultural artel', participants raised several questions about specific governmental policies that affected their day-to-day lives. ${ }^{21}$ They wanted to know why workers did not pay taxes on their gardens or deliveries, but the collective farmers did. They also wished to know why the peasants' workday was not limited to seven hours, ${ }^{22}$ why fixed working hours were not established on the collective farm, and why there was a shortage of manufactured goods in the countryside..$^{23}$ On the "Red October" collective farm, the farmers wished to know why they paid both individual and collective farm taxes, an issue that exemplified the inequality between them and the workers. ${ }^{24}$ The collective farmers of Falenskii raion further questioned state policy by asking, "why not abolish grain collection in districts with bad harvests, because collective farmers live poorly?" 25

One of the biggest discrepancies that the collective farmers noticed was the lifestyle that husbands could give to their wives. On the collective farms, women had to work the same long hours as the men, sometimes even during their last trimester of pregnancy. Despite the Party and state's rhetorical focus on the paramount importance of labor and the right to work, in the urban centers of the Kirov region, many women were housewives who did not have to balance the double burden of working and raising children. ${ }^{26}$ The collective farmers were quick to note this inequity and demanded that 
the wives of workers and service personnel be obligated to work. Ivan Dokuchaev, a collective farmer, asked that all wives of workers and service personnel be obligated to participate in work on the same level as wives of collective farmers.$^{27}$ Sitnikov, a Party member and chairman of the "Sitniki" collective farm, noted that few wives of service workers worked and some kept servants. He wanted it written into the draft Constitution that they were obliged to work. ${ }^{28}$ Six other suggestions, either from men or collective groups, were made to the draft Constitution to the effect that the wives of workers and technical workers should work. That men rather than women complained about workers' wives not having to work may well be related to the man's role in society. Russian men who were unable to provide for their wives were seen as lesser men than those who could. As such, providing well enough for their families that their wives did not have to work was an important marker of personal worth, one to which collective farm men would have aspired. Such suggestions make clear that the collective farmers used the open forum of the discussion of the draft Constitution to promote what they deemed to be fairness and equity in their lives, particularly in comparison to the more privileged urban population.

This discrepancy in citizenship rights was also obvious in Articles 119 and 120, which provided citizens with the right to rest (119), and the right to material security in old age and disability (120), aspects in which inclusion and exclusion had a very real impact on quality of life. Questions about rights specifically granted to workers and service workers, but not to collective farmers in Article 119 and 120, appeared frequently during the discussion of the draft Constitution. For example, in Slobodskoi district, many participants wanted to know why collective farmers were not insured, why the right to rest was only guaranteed for workers and service workers, ${ }^{29}$ and why elderly collective farmers were not paid a pension. ${ }^{30}$ On the "Khimik" collective farm, the collective farmers were interested in why they were not given paid vacation like workers, in spite of both groups having equal electoral rights. ${ }^{31}$ They also wished to know where it was possible to get vacation funds and medical-leave certificates for collective farmers. ${ }^{32}$ In Nolinskii district, participants questioned why collective farmers did not have weekends and vacations like workers and service workers $\operatorname{did}^{33}$ and how aging collective farmers would be helped. ${ }^{34}$ Participants in Falenskii raion expressed their disapproval of the unequal treatment of collective farmers, stating: "We think it is wrong when collective farmers receive medical treatment only after paying, as it will be in the new Constitution." 35 They wanted to know why a state that had promised equal rights, even to former enemies, was excluding such a large portion of its population.

The inhabitants of the Kirov region did not hesitate to make suggestions to address this perceived unfair treatment. Of the 382 suggestions made to Article 119, 293 (76.7 percent) were about giving collective farmers vacations, with Article 120 containing 15 additional suggestions about vacations. Of the 476 suggestions made to Article 120, 199 (41.8 percent) were 
requests for collective farmers to be included in all aspects of the social welfare system.

Particularly telling is the language participants used in their suggestions. Using the Party's own rhetoric, collective farmers argued that such rights were guaranteed to all citizens of the USSR. As equal citizens who had to bear the same burdens as the working class, collective farmers believed that they were entitled to the same state benefits. At a meeting of the "Eastern Dawn" Artel', ${ }^{36}$ the collective farmers advocated granting "collective farmers regular vacations on equal terms with workers." 37 A similar suggestion was made by Comrade Daregorodneva, a worker at the Iaransk city soviet, who suggested implementing social insurance for collective farmers on equal terms with workers and service workers. ${ }^{38}$ The general meetings of Sitka and Dubrovo villages proposed granting collective farmers, as citizens of the USSR, the right to rest and to work. ${ }^{39}$ Collective farmer S. P. Trukhin suggested that "all citizens of the USSR have the right to rest" should apply to collective farmers as well, and they should be granted wintertime vacations with 50 percent of the median pay or without pay subject to the approval of the collective farm general assembly. ${ }^{40}$ Cherepanov, a collective farmer, contended: "In the furtherance of the erasure of borders between city and countryside, [it is necessary to] establish the right to yearly vacations for collective farmers." ${ }^{41}$ Comrade S. A Rusinov from Karakulinskii raion reasoned that it was necessary to "add [a clause] about yearly vacations for collective farmers with the retention of median pay, because under socialism there will be an equal relationship towards the means of production." 42 The invocation of both the rights of equality and citizenship to justify the extension of these social welfare benefits to collective farmers indicated that the collective farmers had paid close attention to the language being used in the discussion and used that language to press their interests.

This correlation between citizenship and social benefits was also reflected in suggestions that people whose behavior made them unworthy of citizenship should be stripped of their social welfare benefits. Sokolov, from the city of Sovetsk, requested that people who lost their ability to work due to drunkenness, fighting, and other disreputable behavior not be granted the right to social security. ${ }^{43}$ Likewise, at the plenum of Kokorovshinskii rural soviet, a suggestion was made that "it was necessary to count only laborers and to exclude the non-working elements of the citizens of the USSR from receiving social security." 44

It should be noted, however, that even among the collective farmers, not all were considered equally deserving. Some proposals regarding vacations for collective farmers illustrate nicely the social and political stratification that still existed in the countryside. Quite a few suggestions about giving vacations to collective farmers sought to limit that right to a certain strata, such as Stakhanovites, collective farm chairpersons, brigadiers, stable hands, watchmen, and storekeepers, that is, those who worked year-round. ${ }^{45}$ Some advocated granting vacations only to those who worked between 225 and 
325 workdays on the collective farm. Such distinctions by collective farmers reflect the fact that collective farms were reliant on the overall cooperation and hard work of all of their members to thrive. The problems posed by unmotivated collective farmers were demonstrated by comments made during the discussion. For example, at a meeting of the collective farmers of the "Surf" artel', a suggestion was made to separate out those collective farmers who consistently behaved lazily towards collective work, giving them individual tasks and having a brigadier directly supervise them. ${ }^{46}$ One collective farmer went so far as to suggest expelling those who did not do any work on the collective farm but made use of collective farm rights from the collective farm. ${ }^{47}$ Using vacation as leverage would not only reward those who worked hard with well-deserved rest, but could be used to spur the less active collective farmers to work.

Who was entitled to social benefits was not the only divisive issue; who should pay for it was contentious as well. There was disagreement between local elites and collective farms as to what institution should bear this financial burden. Party members and members of the local state apparatus tended to favor the formation of collective farm mutual aid societies to defray the costs. Comrade V. A. Troshkov suggested sending sick collective farmers who needed medical treatment to resorts at the expense of the collective farms or of the mutual aid societies. He wanted to add to the Constitution that "every collective farm must purchase 1-2 travel vouchers to resorts for the best Stakhanovites and shockworkers of the field." ${ }^{48}$ Comrade Teplykh likewise thought that collective farms should "implement social insurance on the collective farm's tab and broaden the network of collective farm mutual aide societies" to pay for this expense. ${ }^{49}$ Comrade I. V. Sozonov, too, suggested equally providing "collective farmers life insurance through cooperative organizations with the deductions for insurance coming from the general earnings of the collective farm, ${ }^{50}$ whereas Comrade E. M. Istomin proposed insuring collective farmers on the government's tab, but deducting a percent corresponding to government expenditures on their members from the collective farm. ${ }^{51}$

However, many collective farmers felt strongly that the state had the responsibility to look after their well-being and should do so with its own funds, rather than collective farm money. ${ }^{52}$ The collective farmers of "Combine" artel' addressed this issue, stating, "The state should provide aid to aging collective farmers, not the mutual aid societies, which are created with the collective farmers' personal earnings." ${ }^{53}$ Collective farmer Fedor Stepanovich Kislitsin suggested that the state pay for the widespread development of social insurance for workers, service workers, and collective farmers. He concluded that this might take some time to implement, but like the achievements elucidated in the new Constitution, he believed that with time it was possible, noting, "We formed the Constitution not in one or two years but ten, it might even be more years. If there is not the ability to do this now, in the future it is necessary to implement it." ${ }^{54}$ Such disagreements 
over who should receive benefits and benefit funding showed that the collective farmers were actively engaged and politically astute, even if they did not reach a consensus. However, there was an overall consensus among the collective farmers that, as citizens of the USSR, they deserved access to benefits.

Social welfare benefits were not just the concern of the collective farmers, though. Urban dwellers and service workers also relied on state benefits; many saw it as a social safety net. The allocation of pensions for a number of groups, such as veterans, orphans, the elderly, and the disabled, made up almost one-fourth (19.5 percent) of all suggestions made to Article 120. Fairness and the state's obligation to provide for its citizens were at the center of many of these suggestions. For example, the teachers' collective of Burkovskoi Elementary School sent a letter to the Central Executive Committee in Moscow detailing its concern about providing for children when a parent died. Given the detailed nature of the report, the collective clearly expected the state to seriously consider its proposal and act on it. They suggested that,

if a husband or a wife died and left behind 1-6 minor children plus an able-bodied spouse, the remaining spouse must receive a pension for the children in the amount of $100 \%$ of the salary of the deceased until the end of the minority of the youngest child, but that the pension should be proportionately reduced upon the end of the minority of every child.

They provided a specific formula that they proposed be used to calculate a family's benefits:

y4: four children

$\mathrm{X}: \quad$ the wage of the spouse

7: $\quad$ the received pension

$\mathrm{C}$ : the amount of the pension's decrease per child

$\mathrm{K}$ : the pension imparted to minor children

$$
\begin{array}{ll}
1 & \mathrm{y} 4=\mathrm{X}=7 \\
2 & \mathrm{Y}-1=\left(7-\mathrm{C} / 3^{*} \mathrm{Y}\right)=\mathrm{K} \\
3 & \mathrm{Y}-2=\left(7-2 \mathrm{C} / 2^{*} \mathrm{Y}\right)=\mathrm{K} \\
4 & \mathrm{Y}-3=\left(7-3 \mathrm{C} / 1^{*} \mathrm{Y}\right)=\mathrm{K} \\
5 & \mathrm{Y}-4=\left(7-4 \mathrm{C} / \mathrm{Y}^{*} \mathrm{Y}\right)=\mathrm{K}^{55}
\end{array}
$$

Fairness, providing equally for every child, was at the heart of the formula.

Of the many people who co-opted the language of fairness, state building, and class struggle to advocate for their personal interests, one of the most compelling examples comes from Timofei Ovechkin, a former accountant from a forest products collective farm in Shurminskii raion. He used the Party's language and appealed to a sense of fairness to endorse his suggested change to the draft Constitution, raising the amount of money that 


\section{2}

he received as a pension. He addressed his case directly to the state's leaders on the Central Executive Committee, utilizing a traditional letter-writing model. ${ }^{56}$ Ovechkin contextualized his request within the democratization of the USSR, writing:

In connection with the discussion of the Stalinist Constitution, I cannot describe my enthusiasm at the acceptance of the Constitution, which is clear and thanks to comrade Stalin and his coworkers. And I cannot be silent about the true democracy that Soviet power gives us. ${ }^{57}$

Even as he proceeded to his main argument, raising his pension, Ovechkin was careful to maintain a broader context for his claim. He framed the case for his very specific request in terms of fairness-those who had served in low-paid positions on collective farms and were left unable to work by that service should have greater pensions because they fulfilled their patriotic duty by strengthening collectivization. Although his prose was inelegant, his argument was clear:

pensions should be fixed based on the calculations for the final year of pay and in the absence of such reports, on the basis of qualifications or rating, in particular reflecting the years of class struggle on the collective farms of those freely serving qualified workers, in consideration of the still, at that time, weak collective farms, the organization of poor members, the temporary disruptions of financial ability and progress, which was forced as collective farms pay a very small rate to civilians, and to the worker who saw this, but committed himself to the pursuit of class struggle and came to help, not paying attention to selfish topics of low wages, who is in retirement at this time." 58

Ovechkin noted that he and many other citizens had sacrificed financial and material security to work poorly paid jobs that furthered the development of socialism. He cited his own experience to highlight the level of sacrifice made and the conditions he endured. He lived in the village of R-Mureka in 1927, where:

there was organized a collective farm with an inclination towards forest products production. A sawmill was organized by kulaks, who left at the end of 1928 leaving the poor peasants in need of an accountant, but no one was satisfied with the pay and the collective farm was in danger of going out of business. The initiation of class struggle prompted me to throw aside service as an accountant in a trade society (потребобществе) where the pay rate was around 7 rubles, with overtime and an apartment allowance. I went to work for 45 rubles a month. In 1929 I became sick and over the course of the year had to retire. I wanted to move to a forest organization with a salary of 100 to 
150 rubles as a consequence. They didn't release me, promising future material support from the insurance office, also from the collective farm and the rest of it. The class struggle on the collective farms increased and I committed myself to this activity, threw aside selfish interests but in March of 1932 I got married and retired, and found that my pay from overtime was only 54 rubles and for a third category of disability pension I today receive 18 rubles 59 kopeks. ${ }^{59}$

According to Ovechkin, his long service on the beleaguered collective farm destroyed his health, and he was reliant on his pension to survive, as he could no longer work. He asked the state to take note of his sacrifices and increase pensions for people like him, as small pensions punished such people for their service in badly needed but poorly paid positions. The careful framing of personal concerns in the state's language of equality demonstrated the political acumen of the citizens of the Kirov region, who pushed their local and personal concerns by fitting them into a Soviet cosmology.

Even children responded to the state's call to participate, and they too used the language of revolutionary struggle and state building to give their locally oriented requests union-wide importance. Yuri Alekseevich Krasnoperov, a ten-year-old from the city of Sarpul', wrote (probably with help) a letter to the state and Party leadership. ${ }^{60}$ Yuri's letter demonstrates the mix of intimacy and appeal that marked much Soviet correspondence. ${ }^{61}$ At the end of his letter, Yuri informed the Party leaders that it was his birthday, as if they were friends or relatives. But, at the same time, he couched his appeal to improve the quality of nurseries in the small provincial city of Sarpul' in the language of patriotism. He wrote:

In connection with the new draft Constitution, I ask that you pay attention to children's nurseries and kindergartens in order to maintain their health so that our young generation doesn't die from poor care and also make provisions for directors in such cities as Sarapul', Kirovskii Krai. There are deadly sicknesses in the nurseries here on account of there being insufficient nannies for children. We need children for the replacement of our ranks of school children and also defenders of our Motherland the USSR. Therefore I ask you earnestly to pay attention to my letter. ${ }^{62}$

He emphasized how important healthy children, the cadres and soldiers of the future, were to the state. But the most striking thing about the letter is its address. The address, "To the center of Moscow," is reminiscent of Chekov's short story "Vanka," where a small boy addresses his pleas for help: "to Grandfather, in the village." However, unlike Vanka's cries for help, which were destined to never reach his grandfather and underscored the tragedy and hopelessness of the situation, Yuri's letter was in fact delivered to the Central Executive Committee, which is where I found it gathered 
with thousands of other suggestions in carefully categorized folders. The state obviously took great pains to gather and view the correspondence of all its citizens. The citizens of the USSR in turn used this interest, and their increasing level of education, to directly appeal to central state authorities.

Neither Ovechkin nor Yuri Krasnoperov were unique in using different articles of the draft Constitution as a touchstone for personal desires or pet interests. Many participants in the predominately rural Kirov region chose to use the discussion to offer up their own visions of what socialism should be, which more often than not focused on improving rural inhabitants' daily lives. One of the most pressing issues was access to land and other natural resources that were vital for survival. Peasants had long struggled to gain access to natural resources such as meadows, forests, and waterways. In his work, Crime, Culture, Conflict and Justice in Rural Russia 1856-1914, Stephen Frank notes that crimes, such as stealing wood from private or state forests, were commonplace and often created much friction between the peasantry and the local officials. In Russia's Peasants, Aaron Retish notes the competition for land in the Viatka province from the revolution into the NEP period. ${ }^{63}$ Even following collectivization, land remained a key issue in Kirov. ${ }^{64}$

While the question of the distribution of arable land had been decided in 1935 with the State Act on the Eternal Usage of Land, Article 8 of the draft Constitution brought the issue of land rights to the forefront again. Many collective farmers took advantage of the popular discussion to request eternal access to or ownership of the resources that they had traditionally been denied but felt justified using. In the Kirov region, Article 8 received 263 total suggestions, of which 218 requested giving the collective farmers eternal usage of the forests. Other suggestions proposed that meadows and hayfields be turned over to the collective farms (18 requests) and that collective farms have water rights to local streams and ponds (seven requests). Three additional suggestions to give the forests to the collective farms were submitted for Article 6 (about the allocation of natural resources). These resources were highly prized and jealously guarded. Collective farmers suggested denying access to land and other natural resources to individual smallholders and giving underutilized land to "more deserving collective farms" ${ }^{65}$ so as to "guarantee proper land usage." ${ }^{66}$ The collective farmers argued that access to natural resources should be given to those who best fulfilled the state's mandate of building socialism through collectivized agriculture. Whether that was the motivation behind their claims is unclear, but it is clear that they used the state's discourse to press their case.

Article 9 provided for the continued existence of individual farming in the USSR and was hotly contested in the Kirov region. While Article 9 received far fewer suggestions than Article 8, it too raised important issues of land usage and highlighted social tensions in the countryside. Individual smallholders competed with the collective farmers for resources and the state, while protecting their existence in the Constitution, had enacted a 
series of discriminatory economic measures against them. Individual smallholdings had the potential to fragment collective farm land. In some cases, these smallholders were unpopular because they failed or refused to participate in the voluntary civic work on roads, bridges, etc.; collective farmers were mandated to expend their time and energy on such work. ${ }^{67}$ Therefore, some collective farmers tried to use the language of socialist construction to expand their land holdings and challenge individual smallholders who existed outside of the collective community.

Of the 24 suggestions made to this article, nine were directed against individual smallholders and called for either banning the practice of individual smallholding directly or denying them access to land. For example, a group of collective farmers from the Kalinin collective farm challenged the individual smallholders' existence on the basis of socialist principles, stating "the socialist system of production in the USSR is governmental in form, and therefore the development of independent peasant production cannot be allowed." ${ }_{68}$ Others challenged the smallholders' existence based on the debt that they owed to the state. L. M. Zhuikov, a collective farmer, proposed "to remove the independent smallholders' right to use their garden plot if they owed two years of back taxes and absolutely give it to the collective farms, as the independent smallholders accumulate arrears every year." ${ }^{9} 9$

Land usage was not just a concern of rural inhabitants. Many people who lived in urban areas were recent arrivals from the countryside and maintained strong connections to their rural roots. Some of these urban dwellers wanted to know why land was not put aside for workers under the same conditions as for collective farmers. ${ }^{70}$ Kudrin, a Party member and worker at the Votkinskii power plant, suggested that the Constitution "include a point about workers' rights to use the hinterland and haymaking grounds." 71 Likewise, I. K. Markov from the "1st of May" collective farm suggested "securing part of the land for eternal usage for workers and service workers." 72 While such suggestions were not numerous, they demonstrate the continued importance of agricultural ties for workers and service workers, and the overall importance of access to land for food production, even in urban areas of the USSR.

The drafters of the Constitution were aware of the citizenry's reliance on domestic food production for household survival. As such, they sought to codify Soviet citizens' rights to personal property while still promoting the construction of a collectivist and socialist society. Perhaps no issue reflected this specifically Soviet understanding of constitutionalism better than the issue of private cow ownership. According to Article 7 of the draft Constitution, buildings, livestock, and tools were property of the collective farms, but every collective farm household had the right to "a small garden plot and personal property for subsidiary economic activity on the garden plot, livestock, including a milk cow (продуктивный скот), fowl and other petty agricultural stock as specified in the charter of the artel'." 73 Such issues were not included in most Western constitutions, but in the 
USSR, the right to own private livestock was present in Stetskii, Tal', and Iakovlev's first complete draft of the draft Constitution and became part of the ratified 1936 Constitution. As noted earlier in Chapter 1, this level of specificity was part of the overall Soviet conceptualization of a constitution as a list of very specific achievements, rights, and duties, rather than as a list of broad guiding principles. The prohibition of owning a lot of livestock signaled the victory of collectivization over personal smallholding and of state ownership over private ownership. Yet, such an article created a constitutionally protected niche for personal property and agriculture alongside collective agriculture.

As mentioned, earlier in 1935, the Kirov regional authorities had limited the number of personal cows that a collective farmer could own as a way to strengthen collective farms and to promote the growth of collective livestock holdings. Up to that point, many collective farmers had been devoting most of their efforts into caring and raising their own livestock, thereby neglecting the collective herds that the state deemed vital. However, the state recognized the importance of cows to supplement the collective farm payments in kind and to help households attain a better standard of living. As a result, in 1934-1935, when the state and Party were trying to strengthen collective farms, the lack of a milk cow (безкоровность) was one of the main disparities among collective farm households they tried to address. Private cows provided important sources of food for large families in the countryside, and the limitations imposed unfair disadvantages on large families who had many young children. Although young children ate, they were not accounted for in the division of collective farm goods, as they were not able to work. Thus, multiple household cows would have allowed them to make up the shortfall.

Given the importance of private cows in everyday life, it should not be surprising that this issue was raised during the discussion of the draft Constitution. In the Kirov region, there were three recorded suggestions to amend the number of cows constitutionally allowed. At the general meeting of the "Stepan Razin" collective farm, it was suggested that collective farmers with large families be authorized to have two cows for personal use. ${ }^{74}$ Shabalin, a worker from Kirovskii raion, suggested that collective farmers having eight to ten members in a family be allowed to have two milk cows. ${ }^{75}$ Another collective farmer, Shikalov, made an analogous suggestion. ${ }^{76}$ Although the numbers were small, the constitutionality of multiple cow ownership resonated with people and illustrates the personal socioeconomic issues addressed in the draft. Cows helped to define quality of life in the countryside, and multiple cows would help to raise the standard of living for large families. The suggestions about cows serve to illustrate that many of the very personal, seemingly irrelevant suggestions about the draft Constitution were responses to state policies and procedures outlined in the draft. What in any other country would have been a legislative initiative became a constitutional principle in the USSR. 
The popular suggestions provide insight into the issues that preoccupied Kirovites, as well as how they interpreted socialism based on their daily experiences and interactions with the Party and state. In particular, reframing citizenship to include all inhabitants of the USSR and the selective expansion of citizens' rights and privileges became a source of debate for many of the participants. In Kirov, the participants in the discussion focused on including or excluding people from citizenship rights and/or corresponding benefits, while stressing issues that would create safe, stable, and materially secure lives for themselves. They used the rhetorical and political tools that the state had given them to agitate for their interests, often citing state policies or their contributions to state-building efforts to justify increased material benefits and political equality for themselves or their community. The evidence in the chapter makes clear that many discussants were politically active and engaged in a dialogue with the state so as to promote their interests, which were often drastically different from the needs and expectations that the state had been promoting through its managed discussion of the draft Constitution.

\section{Notes}

1 GASPI KO, f. 1293, op. 2, d. 43, 1. 8.

2 J. Arch Getty, "State and Society Under Stalin: Constitutions and Elections in the 1930s," Slavic Review, Vol. 50, No. 1 (Spring 1991), 26.

3 Getty, "State and Society Under Stalin," 27.

4 Davies, Popular Opinion in Stalin's Russia: Terror, Propaganda and Dissent 1931-1941 (Cambridge: Cambridge University Press, 1997), 107-108.

5 Getty, "State and Society Under Stalin," 28; Davis, Popular Opinion, 107108.

6 GARF, f. R-3316, op. 8, d. 222, 1. 1.

7 Article 109 had 106 suggestions, Article 132 received 171 suggestions, and Article 142 received 56.

8 GAKO, f. R-2168, op. 1, d. 474, 1. 120.

9 For a treatment of this distinction in the pre-revolutionary period, see: Daniel Fields, Rebels in the Name of the Tsar (Boston: Houghton Mifflin, 1976).

10 For a more in-depth look at the development of the modern socialist definition of citizenship and citizenship rights, see: T. H. Marshall, Citizenship and Social Class and other Essays (Cambridge: Cambridge University Press, 1950).

11 GASPI KO, f. 1255, op. 2, d. 400, 1. 132.

12 "Builder" collective farm, Verkhoshizhemskii raion, GASPI KO, f. 1255, op. 2, d. 400, 1. 130.

13 "New Life" collective farm, Verkhoshizhemskii raion, GASPI KO, f. 1255, op. 2, d. 400, 1. 131.

14 "Red Star" collective farm, Vozhgal'skii raion, GASPI KO, f. 1255, op. 2, d. 400, 1. 173.

15 Kigbaevskii rural soviet, Sarapul'skii raion, GASPI KO, f. 1255, op. 2, d. 400, 1. 181.

16 Village of Zernovgoroe in Sovietskii raion, GASPI KO, f. 1255, op. 2, d. 400, 1. 174 .

17 GASPI KO, f. 1255, op. 2, d. 400, 1. 178. 
18 GASPI KO, f. 1255, op. 2, d. 400, 1. 174.

19 GASPI KO, f. 1255 , op. 2, d. 400, 1. 175.

20 "Dawn of Socialism" collective farm, Kirovskii raion, GASPI KO, f. 1255, op. 2, d. 400, 1. 173; GASPI KO, f. 1255, op. 2, d. 224, 11. 38-43.

21 Chirkovskii rural soviet, Slobodskoi raion.

22 Farmers in Falenskii raion also questioned why a seven-hour working day for collective farmers was not stipulated in the draft constitution. GAKO, f. R-2168, op. 1, d. 474, 1. 282.

23 GASPI KO, f. 988, op. 1, d. 202, 1. 30.

24 Il'inskii rural soviet, Slobodskoi raion, GASPI KO, f. 988, op. 1, d. 202, 1. 30.

25 GAKO, R-f. 2168, op. 1, d. 474, 1. 282.

26 Despite not working long hours like their rural counterparts, housewives in urban areas often felt themselves to be second-class citizens who were dependent on their husband's status. Sheila Fitzpatrick argues that the women from this elite group actually discouraged women from working and instead promoted volunteerism as a path of female independence. Housewives from the cities of Kotel'nich and Kirov had well-organized circles, and many were active within the Party. They used the discussion of the Constitution to petition for familial issues, such as child custody, alimony, and specific privileges for housewives, such as state benefits and the right to rest. For more information on the activities of housewives in the 1930s, see: Sheila Fitzpatrick, "The Wives Movement," Everyday Stalinism: Ordinary Life in Extraordinary Times: Soviet Russia in the 1930s (New York: Oxford University Press, 1999), 156-164.

27 "Communard" collective farm in Falenskii raion, GASPI KO, f. 1255, op. 2, d. $400,1.28$.

28 Falenskii raion, GASPI KO, f. 1255, op. 2, d. 400, 1. 28.

29 GASPI KO, f. 1255, op. 2, d. 224, 1. 59; a similar suggestion was documented on Merzliakovskii collective farm, Il'inskii rural soviet, Slobodskoi raion, GASPI KO, f. 988 , op. 1, d. 202. 1. 30.

30 GASPI KO, f. 1255 , op. 2, d. 224, 1. 59.

31 Omutninskii district, GAKO, f. R-2168, op. 1, d. 474, 1. 13. This suggestion without attribution to a specific collective farm also appears in GAKO, $\mathrm{f}$. R-2168, op. 1, d. 474, 1. 120; and GASPI KO, f. 1255, op. 2, d. 224, 1. 30.

32 GAKO, f. R-2168, op. 1, d. 474, 1. 120; this suggestion also appears in GASPI KO, f. 1255 , op. 2 , d. $224,1.30$.

33 GASPI KO, f. 1255 , op. 2, d. 224, 1. 3.

34 GASPI KO, f. 1255 , op. 2, d. 224, 1. 6.

35 GAKO, f. R-2168, op. 1, d. 474, 1. 282.

36 Slobodskoi district

37 GASPI KO, f. 988, op. 1, d. 202, 1l. 1-23.

38 GASPI KO, f. 1255, op. 2, d. 400, 1. 121.

39 Kotel'nicheskii raion, GASPI KO, f. 1255, op. 2, d. 257, 1. 47.

40 "Path to Socialism" collective farm, Kotel'nicheskii raion, GASPI KO, f. 1255, op. 2, d. 224, 1. 22. Materials also found in GAKO, f. R-2168, op. 1, d. 473.

41 "Development" collective farm, Sarapul'skii raion, GASPI KO, f. 1255, op. 2, d. $400,1.83$.

42 GASPI KO, f. 1255, op. 2, d. 400, 1. 77.

43 GASPI KO, f. 1255, op. 2, d. 400, 1. 112.

44 Darovskoi raion, GASPI KO, f. 1255, op. 2, d. 400, 1. 115.

45 GASPI KO, f. 1255 , op. 2, d. 400, 1. 83.

46 Vozhgal'skii raion, GASPI KO, f. 1255, op. 2, d. 400, 1. 29.

47 "Victory" collective farm, Lebiazhskii raion, GASPI KO, f. 1255, op. 2, d. $400,1.29$. To be a registered collective farmer but to work in a factory or on 
seasonal migrant work (otkhod) was a pretty common occurrence and posed a constant problem for collective farms in the 1930s. These members were eligible for a lower tax rate and other privileges but contributed nothing to the farm.

48 "Krasnoarmeets" collective farm, Votkinskii raion, GASPI KO, f. 1255, op. 2, d. 400, 1. 105.

49 Elizarovskii rural soviet, Lebiazhskii raion, GASPI KO, f. 1255, op. 2, d. 400, 1. 104.

50 "Bolshevik" collective farm, Shurminskii raion, GASPI KO, f. 1255, op. 2, d. 400, 1. 98.

51 "Dzerzhinskii" collective farm, Kaiskii raion, GASPI KO, f. 1255, op. 2, d. $400,1.98$. The exception to this rule appears to be Comrade Iakimov, head of the building engineering department on the collective farm "Stalin," Falenskii raion. He suggested implementing personal insurance for the purpose of material security in old age on the government's tab and based upon the expenditure of the collective farmers: GASPI KO, f. 1255, op. 2, d. 400, 1. 96.

52 There are collective farmers, such as in Shitmanovskii rural soviet, who favored the idea of sick and disabled collective farmers being supported by the collective farms' earnings. GASPI KO, f. 1255, op. 2, d. 400, 1. 106.

53 Zuevskii raion, GASPI KO, f. 1255, op. 2, d. 400, 1. 106.

54 “On Lenin's Path" collective farm, Arbazhskii raion, GASPI KO, f. 1255, op. 2, d. 400, 1. 114; also GASPI KO, f. 1255, op. 2, d. 400, 1. 107.

55 GARF, f. R-3316, op. 41, d. 83, 1. 101.

56 Sheila Fitzpatrick, "Supplicants and Citizens," 80.

57 GARF, f. R-3316, op. 41, d. 83, 1. 71.

58 GARF, f. R-3316, op. 41, d. 83, 1. 71.

59 GARF, f. R-3316, op. 41, d. 83, 1. 71.

60 GARF, f. R-3316, op. 41, d. 84, 1. 35.

61 See Sheila Fitzpatrick, "Supplicants and Citizens: Public Letter Writing in Soviet Russia in the 1930s," Slavic Review, Vol. 55, No. 1 (Spring 1996), 78-105; Mattew Lenoe, "Letter Writing and the State," Cashiers du Monde Russe: Russie, Empire Russe, Union Sovietique, Etats Independants, Vol. 40, No. 1-2 (1999), 139-169.

62 GARF, f. R-3316, op. 41, d. 84, 1. 35.

63 Stephen Frank, Crime, Culture, Conflict and Justice in Rural Russia 18561914 (Berkeley: University of California Press, 1999).

64 GASPI KO, f. 6777, op. 3, d. 61, 1l. 180-181.

65 GASPI KO, f. 1255 , op. 2, d. 400, 1l. 8, 12, 13, 18, 19; GASPI KO, f. 1255 , op. 2, d. 224, 11. 38-43.

66 GASPI KO, f. 1255, op. 2, d. 400, 11. 16-17, 19.

67 This issue is addressed by I. E. Zelenin in "Byl li 'Kolkhoznyi neonep'?” Otechestvennaia istoriia, No. 2 (April 1994).

68 Belokholunitskii raion, GASPI KO, f. 1255, op. 2, d. 400, 1. 26.

69 From the "Red Farmer" collective farm in Chernovskii raion, GASPI KO, f. 1255, op. 2, d. 400, 1. 26.

70 GAKO, f. R-2168, op. 1, d. 474, 1. 277.

71 GASPI KO, f. 1255, op. 2, d. 400, 1. 226; GAKO, f. 2168, op. 1, d. 474, 1. 340.

72 Kirovskii district, GASPI KO, f. 1255, op. 2, d.224, 1l. 38-43.

73 Pravda, June 12, 1936, 1.

74 Kotel'nicheskii raion, GASPI KO, f. 1255, op. 2, d. 257, 1. 48.

75 GASPI KO, f. 1293, op. 2, d. 43, 1. 119.

76 Shikalovskaia artel', Slobodskoi raion, GASPI KO, f. 988, op. 1, d. 202, 11. 1-23. 


\section{Integration, exclusion, and accountability}

Two major aspects of the new draft Constitution were the expansion of electoral and citizenship rights to all people in the USSR ${ }^{1}$ and the establishment of habeas corpus protections for the accused. At the local level, citizens accepted what they deemed useful features of these policies, while core aspects, which threatened local stability, were met with resistance and hostility. Kirovites embraced Stalin's mandate that democracy be a tool for making local officials accountable for their behavior and failures. They had many suggestions to increase their ability to hold local officeholders accountable and demonstrated their willingness to remove incompetent or corrupt officials during the 1936 local elections, which this chapter discusses. But, Kirovites prized safety and stability, particularly in the countryside where the state was the weakest. As a result, they overwhelmingly rejected the re-enfranchisement of those stripped of their rights and habeas corpus protections. In their place, the inhabitants of the Kirov region proposed counter-suggestions to keep voting restrictions and to make it easier for the police and citizens to apprehend criminals.

In the second half of 1935, a series of decrees abolished social criteria for entrance to higher education and marked the reversal of harsh discrimination policies against people with "class alien" backgrounds. However, many Soviet citizens, who continued to mistrust these groups, met this change in state policies with much hostility. Sarah Davis notes that many workers felt such measures would reduce the opportunities for them to gain higher education, and that without positive discrimination, the working class would once again be relegated to its former lowly social position. ${ }^{2}$ The distrust of former kulaks was often rooted in village politics and property issues. Priests and other disenfranchised religious figures present a more complicated picture. Most of the Soviet-era studies focus mainly on the repression of the clergy by the state and were written after perestroika by clergymen. Some pre-revolutionary studies of the peasantry mention that peasants were often distrustful of the local priests, who were often viewed as greedy and corrupt. Despite the mass of popular suggestions that demonstrate a popular distrust of priests, no in-depth studies exist on popular attitudes towards the clergy in the 1930s, which lies beyond the scope of this project. 
However, in the Kirov region, the state's new, benevolent attitude toward the former lishentsy (those legally deprived of voting rights), particularly towards priests and other members of the Orthodox Church, was met with both resistance and confusion during the public discussion of the draft Constitution. Discussants wanted to know, "Will priests be able to use voting rights?", "Why are priests allowed the right to be elected and to elect people to the soviets?", ${ }^{4}$ and why priests and members of "religious cults" ${ }^{5}$ were given "broad democracy in the election." Some of the participants appeared to be asking for clarification, while others stated or implied that the expansion of the electoral franchise would have negative consequences for both the state and its citizens. In Omutninskii raion, the collective farmers were concerned with whether members of religious cults would be elected in elections to the soviet. ${ }^{7}$ They also asked if members of religious cults would be allowed to participate in elections and whether they would elect classalien people who were currently deprived of voting rights. ${ }^{8}$ Participants elsewhere in the Kirov region wanted to know if "priests and former kulaks can remove nominated candidates and propose their own." Of the 244 suggestions made to Article 135, 203 (83.2 percent) of them were related to limiting the voting rights of former lishentsy and "cult members." For reasons that are not clear, "cult members" attracted more ire than the former kulaks, with 130 suggestions proposing either stripping them of their right to vote, their right to be elected to office, or both. By comparison, only 73 suggestions targeted the electoral rights of the former kulaks and landowners.

The participants in the discussion opposed the extension of the franchise to former lishentsy for several reasons. There were widespread fears that the formerly disenfranchised people would gain positions of power and in some cases try to reclaim land or property that had been redistributed. ${ }^{10}$ Some expressed fears that the former lishentsy would use their new rights to infiltrate the state apparatus and perhaps establish their own small, nepotistic governing circles. Such fears were not unfounded. NKVD Party cell reports for 1936 noted that on at least one occasion, a former kulak was elected to the rural soviet, and he put his friends and supporters in locally powerful positions. ${ }^{11}$ The participants in the discussion were well aware that many of the formerly disenfranchised were still locally influential and quite capable of using their new rights to promote their interests and settle old scores. ${ }^{12}$ One discussant, Maslennikov, argued that granting electoral rights to kulaks and having secret elections might allow foreign elements to be elected to the local administration. He therefore contended, if they give kulaks the right to vote, it needed to be through open and not secret elections. ${ }^{13}$ Similarly, D. A. Shabalin, a Party member, considered it inappropriate to allow the former lishentsy, who were deprived of rights because of their social character, to be elected, as they might stand up for the interests of the bourgeoisie in the organs of administration. ${ }^{14}$ Such concerns reflect the instability in the countryside and anxiety about the lingering influence of the formerly disenfranchised. 


\section{Integration, exclusion, and accountability}

While concerns about local power shaped the trepidations of some of the discussion participants, others felt that the former lishentsy had not proven themselves worthy of full citizenship rights and the honors and responsibilities that citizenship entailed. For example, collective farmer Kudrevatykh suggested that people who had been deprived of voting rights should be given the right to participate in elections to the soviet only after they proved themselves capable of building socialism. ${ }^{15} \mathrm{D}$. Il'in, a Stakhanovite worker, shared Kudrevatykh's sentiment. He proposed not granting voting rights to members of religious cults because "they aren't occupied with useful work for Soviet society and parasites on society must not be admitted to the elections to the soviets." ${ }^{16} \mathrm{He}$ also suggested that they must not be allowed to stand for election to the soviets, which was the highest responsibility and honor for the laborers of the USSR. ${ }^{17}$

Discussants who opposed the expansion of the franchise often utilized Party messages about the struggle between the forward-thinking workers and peasants, and the remnants of the old regime, to justify their opposition, protesting that "former people" were untrustworthy. N. F. Nikulin, a collective farmer, suggested segregating people who interfered with "our October conquests" and formulating a special article not allowing them to participate in elections. ${ }^{18}$ Similarly, Murav'ev, a collective farmer, asked the state to not give the right to vote to former merchants, landlords, and factory and mine owners as "all of them are enemies of laborers and must not have the right to vote or be elected." ${ }^{19}$ Nor were religious people to be trusted. Ovchinnikov, a collective farmer, recommended that members of religious cults not be granted voting rights, because "at the present time they are still not familiar with work and continue to befog the heads of the laborers." ${ }^{20}$ Comrade Gagarinkov also agreed that cult members "who today pull the wool over the heads of the laborers" should not be eligible to stand for election. ${ }^{21}$ I. P. Plotnikov, a worker and Party member, summed up this distrust, arguing that members of religious cults not be eligible to be elected "as religion is an irreconcilable enemy of socialism." 22 Whether these people had truly internalized the Party's longstanding argument about the dangers of former exploiters and religious people, or whether they were using the Party's rhetoric to further a personal cause, is unknown. But they used the language of the Party to make a compelling argument against the new electoral policies proposed by the same leaders who had given them these ideological tools.

The maintenance of law and order was another area of contention between the central state and the inhabitants of the Kirov region. As noted in the overview of life in Kirov, crime remained a problem, and violence against state and collective farm officials was often reported by word of mouth and in the news. The inability of the state to provide for the security of its citizens, even its officials, led some to think that personal safety and personal property were of secondary concern to the central Party and state leadership. This perspective bred resistance to the implementation of habeas corpus among the 
Table 6.1 Suggestions to Article 127

Breakdown of suggestions related to habeas corpus

Allow local authorities to arrest criminals without the sanction of the procurator

Be allowed to arrest criminals who posed an immediate threat without sanctions

Allow criminals caught at the scene of the crime to be arrested without the sanction of the procurator

Allow the arrest of hooligans without procuratorial sanction

Allow citizens to arrest criminals themselves

Total
Number of suggestions

102

12

40

12

10

223

inhabitants of the Kirov region, particularly in the countryside where state and policing organs had the weakest presence. ${ }^{23}$ Many participants expressed concern that the implementation of habeas corpus would undermine citizens' security and any semblance of law and order in the villages. These concerns were reflected in the suggestions to Article 127, which received 223 suggestions. Of these, 198 (88.8 percent) specifically asked for arrests to be carried out without the sanctions of the procurator (habeas corpus).

As the table above indicates, one of the main reasons people were opposed to habeas corpus was because they believed it would delay the apprehension of the criminals and would allow criminals to either perpetrate more crime or, as Party member M. N. Vorob'ev feared, "hide from proletarian justice." 24

Many suggestions reflected a concern with order and security and a fear of violent crime. V. Ia. Kolosov proposed that the state bear increased responsibility for safeguarding social tranquility in the village by taking drastic measures against drunkenness, hooliganism, and rowdiness. ${ }^{25}$ The collective farmers of the "Truth" collective farm asked the state to grant the police the right to arrest "obvious criminals" who threatened social order. ${ }^{26}$ Other collective farmers demanded that those perpetrating hooliganism and thievery, which "was a blight on the people, be quickly arrested on location without the sanctions of the procurator." 27

The suggestions made to Article 131, about safeguarding property, likewise reflected popular concern with stability in the countryside. Safeguarding socialist property was one of the main priorities of the Soviet state and the area on which the procuracy focused much of its attention and resources. And while some of the citizens of the Kirov region also expressed concerns about the destruction and theft of socialist property, ${ }^{28}$ the majority of suggestions made reflected a general concern with maintaining order.

Almost half of the suggestions made to Article 131 involved expanding the definition of "enemies of the people" to address various local problems, such as disorder on the collective farms and hooliganism. Such suggestions demonstrated that disorder in the countryside, particularly on collective 


\section{Integration, exclusion, and accountability}

farms, was an immediate threat to the well-being of the collective farmers. And indeed, as discussed in the overview of life in the Kirov region, poor organization and poor cooperation on a collective farm could spell disaster for all of the members. Therefore, collective farmers were searching for ways, such as expulsion or arresting those disturbing the peace, to regulate the behavior of their members. For instance, at the general meeting of the October artel', ${ }^{29}$ some in attendance suggested that people systematically destroying social order or engaged in hooliganism should be considered enemies of the people. ${ }^{30}$ At a rural soviet plenum, ${ }^{31}$ it was suggested that all people, who are "feloniously and habitually negligent or harming the collective farm, through the destruction of labor discipline, be considered enemies of the people." ${ }^{32}$ Elsukov, a Party member and brigadier, ${ }^{33}$ took this idea a step further by demanding that "administrative measures be taken toward people encroaching on socialist property, by forcible resettlement from the limits of a given locale, where there has been an obvious crime." ${ }^{34}$ Kirovites wished to exclude criminals, kulaks, and religious sect members from participating in Soviet governance and from legal protections that would make them harder to control.

However, participants in the Kirov region actively took up democratic initiatives proposed in the draft when these measures gave them more control over local affairs. Stalin and other leaders felt that by making the Soviet system more participatory, it would enable the masses to police and remove unsuitable local representatives. This call for accountability dovetailed with Stalin's policy to give voice to the "little people," in which, as the local Party and state apparatus grew increasingly beyond the control of the central Party and state leadership, central officials turned to increasingly extreme means to control them, including encouraging local workers and officials to denounce their bosses publicly. ${ }^{35}$ Therefore, during the discussion of the draft Constitution, participants were encouraged to criticize local officials who had been lax in fulfilling their duty and to replace them with more competent and politically active representatives.

The central state and the citizens of the Kirov region both had a vested interest in having competent and accountable local officials. Many participants in the popular discussion proposed suggestions to make both the judiciary and local soviets more effective and responsive to their constituents. One of the proposed methods for making the judiciary more effective was to reinstate comrade courts and expand the number of social courts, which would fall under the preview of an individual enterprise or collective farm. In total, 40 such suggestions were made to several different articles of the draft Constitution. The workers and service workers at the Murashinskii raion supply union (Райпотребсоюз) suggested the organization of comrade courts on the state and collective farms because they got good results and freed up the people's courts from petty cases. ${ }^{36}$ While expediting the judicial process may have been a concern for some, educating people about the rule of law was another reason for suggestions to reinstate people's courts 
and people's judges. I. E Mashkovtsev, a collective farmer, stated that the people's judges needed to be elected from the local citizenry and that these judges should be obliged to conduct explanatory work in the localesthat is, to explain the fundamental provisions of revolutionary legality. ${ }^{37}$ Likewise, Zaleshin, a Party member and worker at the Krai Court in Kirov, requested the reinstatement of social courts because such courts were "one of the forms of re-education and development of laborers ... it is necessary to organize them under the rural soviets, enterprises, and factories." ${ }^{38}$ This didactic function was an important one for both the people and the state, which had in the past organized show trials to demonstrate the rule of law as well as the limits of acceptable behavior, and several additional suggestions focused on the edifying functions of the court system.

Legal education for judges and citizens was also proposed as a way to raise the level of competency of the judiciary and to help citizens connect with and trust the legal system. For example, Bazhutin, a Party member and trade union organizer, suggested that elected (lay) judges be compelled to attend judicial tutorial sessions and to study the judicial science of Soviet laws, because the judges might be elected directly from workers in production..$^{39}$ In his suggestion, Bazhutin addressed two of the major challenges facing the Soviet judicial system-how to maintain close ties to laborers while simultaneously maintaining a high level of legal competence. Early Soviet courts had elected laborers and instructed them to administer "revolutionary justice" without clear formal legal guidelines. This practice, which resulted in a very uneven application of judicial principles and punishments, brought a lack of predictability to the judicial system. Vyshinsky addressed this shortcoming by advocating professionalizing the judiciary and instituting strict legal codes, though lay judges, elected by the people but with little actual power, endured as a reminder of revolutionary legality. However, the professionalization of the judiciary destroyed the image and position of the citizen judge that the revolutionary Soviet state had been trying to create so as to make the judiciary closer to and more responsive to the will of the people, rather than just a branch of the state apparatus. ${ }^{40}$

There were also calls for more direct methods of holding the judiciary responsible for their actions. Many people believed that local officials, including lay judges and procurators, should report to their constituents. For example, V. A. Erofeev suggested that, to improve the work of the people's judges, they should be obligated to account for themselves in front of the voters twice a year. Specifically, he wanted them to report on the progress of their work and its characteristics, changes in the law, and citizens' responsibility for law violations. ${ }^{41}$ Thirty-three other suggestions about mandating judges and procurators reporting to voters were also put forth during the discussion. Requiring judicial officials to give reports allowed the voters to identify who was ineffective at their job and hold incompetent judicial officials accountable for their actions. For example, the inhabitants of Shakhnery and Malyshenki villages suggested "making people's judges accountable for 
illegal convictions." ${ }^{42}$ Arziaev, a Party member, developed this idea even further, suggesting recalling and re-electing people's judges at the request of the voters in the case of inappropriate work by judges. ${ }^{43}$ Such suggestions illustrate that the inhabitants of the Kirov region were willing to use grassroots, direct democracy as a tool to keep elected judicial officials in line.

Concerns with competence and accountability extended to other state officeholders, and discussants offered similar suggestions for increasing the accountability of the local soviets, strengthening the connections between representatives and their constituents and raising the competency of representatives in organs of power. One way to promote stronger ties between representatives and their constituents was to decrease the number of citizens whom they represented. I.A. Mashkovtsev, a collective farmer, suggested that delegates to the Supreme Soviet represent 100,000 people, as opposed to 300,000 , as a smaller constituency would allow elected officials to better be connected with the voters and at the same time enable them to react to problems in the locales. ${ }^{44} \mathrm{~A}$ smaller constituency was also proposed to increase the responsiveness of rural soviet officials. Nina Tarasova suggested that rural soviets must encompass no more than 1,000 people, and the radius of the rural soviet must be no more than 5 kilometers to make the local power closer to the population. ${ }^{45}$ By making both All-Union and local officials more accessible to their constituents, whether through decreasing the number of people they represented or limiting the distance constituents had to travel to meet with their representatives, such suggestions represented a desire to make officials responsible to their constituents and to enable citizens to evaluate the behavior of elected officials.

Raising local officials' level of competence was of particular concern. Of the 50 total suggestions made to Article 95, three-quarters (37) focused on terms for representatives in the rural soviets. For example, S. P. Odegov, a collective farmer and order winner, asked that elected deputies to the soviets serve not for two years, but for four years, so that representatives could better adapt to the work and be more effective. ${ }^{46}$ Likewise, at the plenum of Koriakinskii rural soviet, a suggestion was made to elect deputies to the rural soviets for three years rather than two, so they could better master the work. ${ }^{47}$ To promote competent work at the local level, the inhabitants of the Kirov region suggested that "the soviet of the deputies of laborers report about their work to their laboring constituents." 48 In total, 52 such suggestions were recorded during the discussion of the draft Constitution.

In addition to suggesting ways to make representatives more accountable and responsive in general, some people took the public discussion as an opportunity to criticize local officials who they did not think were doing satisfactory work. Moscow encouraged participants to use the discussion and the subsequent local soviet elections to criticize and remove ineffective local officials. Stalin himself called on the citizens of the USSR to use democracy as a whip to prompt local officials to be more effective and responsive to their needs. Comments made during the discussion of the draft Constitution 
suggest that many people in the Kirov region were dissatisfied with the work of the local soviets and state officials. N. I. Piatin suggested that in future elections to the soviet, it was necessary to elect the best people, as those elected in the previous election were unable to work..$^{49}$ Another participant asked that in future election campaigns, more seriousness be given to the nomination of candidates for deputy. ${ }^{50}$ Reports from District Executive Committees and the Regional Executive Committee also reflected discontent with the work of local officials. ${ }^{51}$

The use of the discussion as a forum to criticize, and even attack, deputies whom citizens believed were not sufficiently representing their interests once again demonstrated how the participants seized the open forum that the state provided and used it to agitate for their own interests. And while the language used against local officials may have echoed official discourse, many of the reasons that deputies were dismissed from work were local and economic. For example, collective farmer V. I. Sozinov was recorded as saying,

Our Constitution is the most democratic in the world. Everyone has the right to vote and to be elected. Only those who are worthy of great honor are elected to the soviets through secret ballot, but we won't elect idlers to the soviet. Ivan Sozinov works poorly for us on the collective farm and we won't elect him to the soviet. ${ }^{52}$

By framing his criticism within the context of service as the greatest honor that a Soviet citizen could have, V. I. Sozinov made Ivan Sozinov's poor work a matter of national and not just local importance. Likewise, during the discussion at a meeting of the "Thirteenth Anniversary of October" collective farm, the collective farmers stated that:

a soviet deputy must be a model, through his own personal example he must lead the masses of laborers. But our deputy A. F. Gontsov acts completely otherwise. He neglects collective farm work, and didn't do collective farm work, even on the order of the brigadier. Instead of strengthening work discipline on the collective farm [he] breaks it down, persuading the collective farmers to not go to work. There must not be a place for such a deputy in the rural soviet. During the re-elections to the soviets, we will not elect such good-for-nothings, but we will elect the best collective farmers who work in a Stakhanovite method, exemplify proper behavior, and accurately execute soviet laws. ${ }^{53}$

By putting Gontsov's behavior within the context of the larger discussion of constructing socialism, his shortcomings as a deputy took on much greater significance.

A letter to Kaiskii Gornorabochii, the Kaiskii district newspaper, entitled, "The Laborers were the Masters of the Country," provides one of the more interesting examples of the use of official Soviet language to demand better 
work at a local level. The letter writer seized upon the central themes of the discussion of the draft Constitution, such as the improved quality of life in the USSR and working to build socialism, to address local problems such as filth in the rural soviet building and the tardiness of local officials. The letter began by framing the problems with local authorities in the context of the struggle to build socialism:

We read the new draft Constitution. We, workers and collective farmers, attained such overall achievements under the leadership of the Communist Party. Earlier, under tsarist power, they governed us, the landlords and the capitalists didn't ask us and no one dared talk to them. If you would have said something or looked, you would have found yourself with your teeth knocked out or with cuts from a birch rod. [Скажешь чего, того и смотри зубы выбьют или розгами напорют]. Now it is a different affair. Those who we wish are elected deputies in the soviets and we elect those who struggle for the masses, strengthening collective farms, safeguarding our socialist property and caring about us workers.

Having been repressed under the tsars, the peasants emphasized the new opportunities that the Soviet socialist system afforded them. They also used this as a way to emphasize the great disservice that incompetent or corrupt local officials were doing, and not just to the local inhabitants but also to the USSR. When considering the re-election of these officials, the author stated:

Will we re-elect Polonin as the chairman of our Mineevskii rural soviet and Morozov as his deputy? If they will work better we will elect them and if they work as now we will not. They are very slovenly. In the rural soviet it is always dirty, go to the rural soviet and there is nowhere to sit, lessons are conducted whenever they think about it, citizens coming on business wait, wait and [then] leave and have to come again on another day. Earlier it was impossible to appoint an accurate time for lessons on collective farms and in brigades, for example from 9 o'clock to 12 and after 12, so citizens could know and come at the established time. The sections of the rural soviet also work poorly. The chairman doesn't think up lesson plans or call assemblies and another time they didn't meet for three months; it is impossible to work now. The new draft Constitution compels [them] to work in a new manner (заставляет работать по новому), with great care for the citizens of our country, and to strengthen our collective farms. ${ }^{54}$

As this letter suggests, despite the rhetorical focus on state building that seemed to dominate the discussion of local authorities' responsibilities, many of the reasons that local soviet officials were criticized or removed from work were of purely local concern. Such was the case in Pizhanskii district, where the discussion of the draft coincided with the rural soviet deputies' 
reports to their constituents. Utilizing this forum, the collective farmers criticized the work of the Pizhanskii, Semenudrskii, and L. Komarovskii rural soviets for their insufficient development of red corners, reading huts, and mass work..$^{55}$ And popular frustration with the deputies' work had real consequences. During the discussion, two deputies were removed, one from Pizhanskii rural soviet and one from L. Komarovskii rural soviet. ${ }^{56}$ Four other deputies were recalled by the voters for not justifying their trust. ${ }^{57}$

The complaints and reasons for removing deputies varied, but they were inevitably local..$^{58}$ For example, in Murashinskii district, there was widespread criticism of the unsatisfactory work of the soviets and the raiispolkomy, particularly the rural tax commissions and raion tax commissions' untimely investigation of complaints. Two members of the raiispolkom, Tashlykov and Lotapov, were removed from office, and three deputies were removed from rural soviet membership for the inability to do proper work and other "discrediting reasons." ${ }^{59}$ The voters of the agricultural artel', "Red Falcon," in Slobodkinskii rural soviet, accused the deputies of unsatisfactorily engaging in cultural construction, the liquidation of illiteracy and semi-literacy, the organization and strengthening of collective farms, and the improvement of the rural economy. The voters of Nazarovskii rural soviet were even more specific in their complaints against the district executive committee. They complained that the district executive committee unsatisfactorily considered the expansion of local handicraft production, the expansion of an uninterrupted supply of goods at the co-op, necessary seasonal goods, and the timely sending of necessary agricultural machinery on the collective farms. ${ }^{60}$ The failure of local officials in Slobodkinskii rural soviet to address local educational and economic concern resulted in three soviet deputies (M. T. Selivanov, A. A. Leushin, and F. B. Leushin) being removed and replaced by "the best shockworker-collective farmers." ${ }^{61}$ Similarly, voters who were dissatisfied with their service removed deputies from their positions in Votkinskii district ${ }^{62}$ and Arbazhskii district. ${ }^{63}$ Overall, the Regional Executive Committee reported that 779 deputies were removed from 284 soviets for incompetence during the 1936 local elections. ${ }^{64}$

The state had invited its citizens to participate in political discussion and to criticize and remove ineffective local officials from power. The citizens of the Kirov region took up the challenge and, in doing so, pushed for their own personal and local interests. But the evidence also makes clear that they did not always agree with rights granted by the draft Constitution. Many harbored suspicions about granting equal rights to "former people" and about the appropriateness of habeas corpus. However, the differences between the desires and interests of the people and the desires and interests of the state caused conflicts and raised central authorities' suspicions about the true government of the countryside. The fact that the discussion proceeded with both parties working towards different goals had negative consequences in 1937, when in preparation for the elections to the Supreme Soviet, some of the newly enfranchised citizens, the former "former people" 
in particular, began taking up this mantle of political activism and promoting their interests over the interests of the state.

\section{Notes}

1 This included former kulaks and religious sect members who had been previously systematically discriminated against and stripped of their voting rights because of their classification as class enemies.

2 Sarah Davis, Popular Opinion in Stalin's Russia: Terror, Propaganda and Dissent 1931-1941 (Cambridge: Cambridge University Press, 1997), 70.

3 GASPI KO, f. 1255, op. 2, d. 224, 1. 3.

4 GASPI KO, f. 1255 , op. 2, d. 224, 1. 3.

5 The term, "cult member," is how these people were described in the documents. It makes it difficult to determine to whom exactly they are referring, but I suspect "cult member" refers to anyone with religious affiliation.

6 GASPI KO, f. 1255, op. 2, d. 224, 1. 4.

7 GAKO, f. R-2168, op. 1, d. 474, 1. 120; GASPI KO, f. 1255, op. 2, d. 224, 1. 30.

8 GAKO, f. R-2168, op. 1, d. 474, 1. 13. Similar questions also appear in GASPI KO, f. 1255, op. 2, d. 224, 1. 30 and GAKO, f. R-2168, op. 1, d. 474, 1. 120.

9 GAKO, f. R-2168, op. 1, d. 474, 1. 282.

10 While I have found no specific examples of kulaks returning to reclaim land or possessions in the Kirov region, such events did take place in other parts of the USSR. I. E. Smirnova investigates this phenomenon in Ukraine and how it affected the conduction of repression there in "Otrazhenie "kulatskoi operatsii' v dokumentkh partiinykh organov Donetskoi Oblasti," Stalinism v Sovetskoi Provintsii: 1937-1938 massovaia operatsiia na osnove prikaza, No. 00447 (Moskva, Rossiskaia Politicheskaia entsiklopedia, 2009) 673-716.

11 GASPI KO, f. 1290, op. 1, d. 56, 11. 120-121.

12 For more information on how local power was wielded to settle scores and advance personal causes in the Kirov region, see: Samantha Lomb, "Personal and Political: A Microhistory of the 'Red Column; Collective Farm, 193536," The Carl Beck Papers, 2404 2016), http://carlbeckpapers.pitt.edu/ojs/ index.php/cbp/issue/view/178.

13 Urzhumskii raion, GASPI KO, f. 1255, op. 2, d. 400, 1. 189.

14 Kotel'nicheskii raion, GASPI KO, f. 1255, op. 2, d. 400, 1. 203; GASPI KO, f. 1255, op. 2, d. 257, 11. 45, 47.

15 "Red East" collective farm, Chernovskii raion, GASPI KO, f. 1255, op. 2, d. 400, 1. 190.

16 Galva metric section at the Belokholunitskii factory, Belokholunitskii raion, GASPI KO, f. 1255, op. 2, d. 400, 1. 191.

17 GASPI KO, f. 1255, op. 2, d. 400, 1. 200.

18 Kirovskii raion, GASPI KO, f. 1255, op. 2, d. 400, 1. 192.

19 Kirov collective farm, Pizhanskii raion, GASPI KO, f. 1255, op. 2, d. 400, 1. 193.

20 Pizhanskii raion, GASPI KO, f. 1255, op. 2, d. 400, 1. 193.

21 Kaiskii raion, GASPI KO, f. 1255, op. 2, d. 400, 1. 195.

22 “Stroiiadelali" Factory, Kotel'nicheskii raion, GASPI KO, f. 1255, op. 2, d. 400, 1. 196.

23 For more information, see: David Shearer, Policing Stalin's Socialism: Repression and social order in the Soviet Union, 1924-1953 (New Haven: Yale University Press, 2009).

24 Antonovka, Urzhumskii raion, GASPI KO, f. 1255, op. 2, d. 400, 1. 150. 
25 Urzhumskii raion, GASPI KO, f. 1255, op. 2, d. 400, 1. 148.

26 Sanchurskii raion, GASPI KO, f. 1255, op. 2, d. 400, 1. 152.

27 Ashlanskii rural soviet, Urzhumskii district, GASPI KO, f. 1255, op. 2, d. 400, 1. 148.

28 GASPI KO, f. 1255, op. 2, d. 400, 1. 170; GASPI KO, f. 1255, op. 2, d. 400, 1. 164.

29 Ziuzdinskii raion.

30 GASPI KO, f. 1255, op. 2, d. 400, 1. 165; GAKO, f. R-2168, op. 1, d. 473, 11. 53-67.

31 Zausovskii rural soviet, Darovskoi raion.

32 GASPI KO, f. 1255, op. 2, d. 400, 1. 166.

33 From the "Shockworker" collective farm in Makar'evskii district.

34 GASPI KO, f. 1255, op. 2, d. 400, 1. 164.

35 Sheila Fitzpatrick, "How the Mice Buried the Cat: Scenes from the Great Purges of 1937 in the Russian Provinces," Russian Review, Vol. 52, No. 3 (July 1993), 299-320. J. Arch Getty and Oleg Naumov, The Road to Terror: Stalin and the Self-destruction of the Bolsheviks, 1932-1939 (New Haven: Yale University Press, 1999).

36 GASPI KO, f. 1255, op. 2, d. 400, 1. 44.

37 "Political Section" collective farm, Nolinskii raion, GASPI KO, f. 1255, op. 2, d. 400, 1. 47. D. Usnirev, a Party member and accountant at Sibiriakovskii logging enterprise, made a similar suggestion, recommending that organs of the procuracy and the court conduct explanatory work among the laborers about the Soviet legal system, GASPI KO, f. 1255, op. 2, d. 400, 1. 47.

38 GASPI KO, f. 1255, op. 2, d. 400, 1. 48; GASPI KO, f. 1293, op. 2, d. 43, 1. 123. Zaleshin's reference to the pedagogical function of the judiciary reflects the Party's use of show trials as a way to demonstrate normative behavior to its citizens and educate them about legal procedures. For an interesting treatment, see: Elizabeth Wood, Performing Justice: Agitation Trials in Early Soviet Russia (Ithaca, NY: Cornell, 2005).

39 Votkinskii machine-building factory, Votkinskii raion, GASPI KO, f. 1255, op. 2, d. 400, 1. 50; GAKO, f. R-2168, op. 1, d. 474, 1. 340.

40 For more information on the development of Soviet judiciary, see: Eugene Huskey, Russian Lawyers and the Soviet State: The Origins and Development of the Soviet Bar (Princeton: Princeton University Press, 1986); David Shearer, Policing Stalin's Socialism; Peter Solomon, Soviet Criminal Justice under Stalin (New York: Cambridge University Press, 1996); and Peter Solomon's Reforming Justice in Russia, 1864-1996: Power Culture, and the Limits of Legal Order (Armonk, NY: M.E. Sharpe, 1997).

41 GASPI KO, f. 1255, op. 2, d. 400, 1. 47; GASPI KO, f. 1255, op. 2, d. 224, 11. $38-43$.

42 Kotel'nicheskii raion, GASPI KO, f. 1255, op. 2, d. 400 1. 45; GASPI KO, f. 1255, op. 2, d. 257, 1l. 45, 47.

43 Kichminskii raion, GASPI KO, f. 1255, op. 2, d. 400, 1. 49.

44 "Political Section" collective farm, Nolinskii raion, GASPI KO, f. 1255, op. 2, d. $400,1.32$.

45 GASPI KO, f. 1255 , op. 2, d. 400, 1. 39.

46 Zhdanov collective farm, Shabalinskii raion, GASPI KO, f. 1255, op. 2, d. 400, 1. 40.

47 Kotel'nicheskii raion, GASPI KO, f. 1255, op. 2, d. 400, 1. 41; GASPI KO, f. 1255 , op. 2, d. 257, 1. 45. An analogous suggestion was made by D. F. Dvoeglazov, of Sibirskii collective farm in Nagorskii raion. GASPI KO, f. 1255, op. 2, d. 400, 1. 42.

48 GASPI KO, f. 1293, op. 2, d. 43, 1. 123. 
49 Shabalinskii raion, GASPI KO, f. 1255, op. 2, d. 400, 1. 41.

50 GASPI KO, f. 1255 , op. 2, d. 400, 1. 41.

51 However, since most of this information from the Kirov region comes from reports requested from Moscow, and the regional and local officials were specifically asked to provide examples of this behavior, it is difficult to determine whether the use of the discussion for criticizing local officials represented a groundswell of popular democracy aimed at holding local officials responsible to their constituency or if these are isolated incidents that were couched in the language of popular democracy to satisfy demands from Moscow. Either way, it does appear that in some raiony, local officials were removed from their positions of power for poorly performing their official duties.

52 Dinamovets collective farm, Leninskii rural soviet, Shabalinskii raion GAKO, f. R-2168, op. 1, d. 473, 1. 29. It is not clear if the two men were related.

53 Kaiskii raion, GAKO, f. R-2168, op. 1, d. 473, 1. 29.

54 GAKO, f. R-2168, op. 1, d. 474, 1. 52. Similar complaints about the work of Polonin and Morozov were noted in a report from the Regional Executive Committee to the All-Union Central Executive Committee orgotdel' in Moscow as well: GAKO, f. R-2168, op. 1, d. 473, 1. 29.

55 GAKO, f. R-2168, op. 1, d. 474, 1. 103.

56 GAKO, f. R-2168, op. 1, d. 474, 1. 103.

57 GAKO, f. R-2168, op. 1, d. 474, 1. 362.

58 Similar situations occurred throughout the USSR. For more information on this phenomenon nationally, see: Mary Buckley, Mobilizing Stalin's Peasants: Heroines and Heroes of Stalin's Fields (New York: Roman and Littlefield Publishers, 2006).

59 GAKO, f. R-2168, op. 1, d. 474, 1. 193.

60 GAKO, f. R-2168, op. 1, d. 474, 1. 214.

61 GAKO, f. R-2168, op. 1, d. 474, 1. 214.

62 During the discussion of the draft Constitution, from the very beginning, criticism of the work of the soviets' inadequacies unfolded. But during the reporting campaign criticism of insufficiencies, mistakes of the rural soviets strongly unfolded. For example, during the report of Iiul'skii rural soviet in the village N. Kvarsinskii, voters criticized the rural soviet for weak mass work, poor explanation of laws, weak work on cultural-everyday life, construction, the slow preparation of animal food, etc. This same happening was ascertained in Galevskii, Pazderinskii, and other rural soviets, and as a result of incomplete information, four people were removed as deputies: P'chnikov, Kel'chino, Lomaev, and Molchany: GAKO, f. R-2168, op. 1, d. 474, 1. 338. An informational report of results of the discussion in Votkinskii raion notes the criticism in the village of N. Kvarsinskii, but additionally noted that in Mishkinskii, Bakaevskii, and Pazderinskii rural soviets, upon the giving of the reports from the deputies and rural soviets, 15 deputies were removed from rural soviet membership: 11 were removed for not warranting trust, one left, one was arrested, one was removed for embezzlement, and one was removed for systematic drunkenness; GAKO, f. R-2168, op. 1, d. 474, 1. 326.

63 In connection with the discussion of the draft Constitution in Sovizhkii rural soviet, there was expanding criticism of the unsatisfactory work of members of the rural soviet where there was poor work; for inactivity, three members of the rural soviet were removed from work.

64 GAKO, f. R-2168, op. 1, d. 473, 1. 120. 


\section{The Constitution, the 1937 elections, and repression}

The open discussion of the draft Constitution, which allowed citizens to criticize the proposed foundations of the state, coupled with the central leadership's emphasis on free and open elections, created stress on the Stalinist system. While central state authorities initially encouraged the population's open participation, as the discussion progressed and the results from Party and local elections held in late 1936 became clear, the central and local authorities became increasingly concerned about "anti-Soviet" activity among some of the discussants. This anxiety carried over into preparations for the 1937 elections to the Supreme Soviet when reports from the Kirov region indicated that some former kulaks and priests used the relaxing of restrictions to agitate for their own interests and to win representation in some local organs of power. ${ }^{1}$ These reports amplified the anxieties that the central leadership had about the perceived increase in enemy activity throughout the country. The local NKVD Party cell minutes, from which I draw my materials, demonstrated growing anxiety within the NKVD and the community at large. As 1937 progressed, participants at those meetings and in other governmental organs stopped referring to the infiltration of Soviet organs of power by class enemies as a possibility but rather as a reality that needed to be aggressively confronted. This perceived challenge to the dominant role of the Communist Party, which coincided with myriad other factors, such as massive demographic upheaval, the challenges of rapid industrialization, the 1936 economic crisis, ${ }^{2}$ failed verification of Party documents, ${ }^{3}$ and a mounting foreign threat, helped to trigger repression in 1937. This chapter explores how such reports and pressure from the regions contributed to the onset of mass repression in 1937 and its evolution. As this study examines one region of the RSFSR, the purpose of this chapter is not to make overstated claims about the mass repression, but to show ways in which local issues and state concerns overlapped, while also raising questions about popular involvement.

\section{"Anti-Soviet" behavior during the discussion}

Central-state and Party rhetoric during the first months of the discussion emphasized that the destruction of all class enemies had been successful, 
which provided an opportunity for the greater democratization of the USSR through open, multi-candidate elections with full popular participation. This argument dominated the media coverage of the discussion and official state and Party statements. But signs of concern about "anti-Soviet" rhetoric and behavior began to surface in August 1936, coinciding with the first of the major Moscow show trials.

The first specific mention of the need to monitor the public discussion for anti-Soviet activities came on the heels of the Chairman of the Central Executive Committee, Mikhail Kalinin's, August rebuke of regional authorities. Kalinin's reaction stemmed from a lack of reports about the discussion's progress and a plethora of "incorrect" suggestions (discussed in Chapter 3 and the Notes on Sources). In response to Kalinin's complaint, Ivan Akulov, the secretary of the Central Executive Committee (TsIK), required reports from regional officials to answer a very specific list of questions. Reports of anti-Soviet behavior, specifically the "worming in of class enemies during the discussion of the draft Constitution," and what form these activities took, were among the types of information that Akulov requested on behalf of the Central Executive Committee. ${ }^{4}$

Akulov's request was nothing extraordinary. In the past, when confronted with a campaign that did not develop as the central leadership had envisioned, it would castigate lower officials for insufficient effort and call on them to look for class enemies who may have integrated themselves into the process and threatened it from the inside. However, the Central Executive Committee's requests for information about the behavior of class enemy activities during the discussion suggested that they were no longer convinced that class enemies had been as thoroughly destroyed as the official rhetoric indicated. While it could be argued that the Soviet leadership had never believed its own rhetoric about the destruction of class enemies, the expansion of the electoral franchise in the draft and the appearance of this specific line of inquiry about class enemies only two months into the discussion indicate that the leadership had indeed believed that it was safe to make the USSR more participatory. But something occurred during the course of the discussion to change the leadership's assessment of the situation. It is unclear from my research what exactly triggered this reassessment, which coincides with increasing pushes for vigilance in other spheres as well. In his studies of the repression, J. Arch Getty argues that the central Party and state administration was increasingly suspicious of disobedience and silence on the part of regional officials about the fulfillment of campaigns. ${ }^{5}$ Given that Kalinin felt it necessary to criticize regional officials for their failure to send regular and complete reports, it is likely their unresponsiveness triggered the tightening of central control over the discussion and the requests for information about class enemies.

In the Kirov region, Party and state officials set about providing the Central Executive Committee with the requested information. In these reports, the same handful of anecdotes about class enemies keep reappearing, leading to 
the conclusion that such incidents were rare, and these few examples were all that the local officials could find to fulfill Moscow's request. Additionally, regional reports note that most of these complaints were nipped in the bud when they were voiced during the discussion. Meeting organizers, who considered certain opinions anti-Soviet, would often set those dissenters up as straw men in order to reinforce the main state-building narrative. ${ }^{6}$ Therefore, it is hard to gauge how widespread or deep-rooted discontent was in the Kirov region. However, this material is important because the information central authorities received from the provinces was what they used to evaluate the overall progress of the discussion regionally and in the USSR as a whole.

Most of the perceived anti-Soviet incidents recorded in the Kirov region were statements or suggestions made during discussion meetings. Some participants used these gatherings to express dissatisfaction with the standards of living that Soviet power had provided. For example, I. M. Cherninov, a collective farmer, said, "we, from the very beginning of Soviet power waited for improvement, we work like slaves, on our backs they build the cities, factories, but we peasants, our lives become poorer and poorer." Another collective farmer, S. V. Ogorodnikov, announced: "the new Constitution helps nothing, we pay a lot of taxes and these are the benefits derived from Soviet power. Tsar Nikolai II didn't take anything from us and under his rule we lived better." Even some local officials expressed dissatisfaction with the living conditions in the USSR. Egor Avdeevich Gontsov, a Komsomol organizer and member of the Koppashinskii rural soviet, said, "we live now as we earlier lived. As we starved earlier [under the Tsar] in this way, we are hungry today. The new Constitution didn't bring improvement to us."

Even those who recognized the Constitution as a positive document were sometimes critical of the quality of life in the Kirov region, and such comments were labeled anti-Soviet. Koz'minykh, a medical assistant, was reported to say, "the Constitution as a document is good, but not everything is in accord with it. I was in one school where three students sat without a jacket." ${ }^{10}$ Others who believed that the Constitution had little bearing on their lives simply refused to engage in the discussion at all, like the service worker in the Khromonii factory who stated, "we are not interested in the Constitution and will not discuss it." ${ }^{11}$ Like most suggestions, these complaints were often local in nature but took on national significance when sent to Moscow as the voice of dissent.

Statements made at group meetings could easily be cut off by watchful meeting organizers, but "anti-Soviet" interpretations of the draft Constitution, particularly those that empowered religious groups or individual smallholders to challenge foundational state policy, proved more worrisome to the state. For example, Taiarikov, ${ }^{12}$ who had been formerly sentenced to hard labor, formed a group of collective farmers around him and argued that "as the freedom of speech, press and individual small 
holding are now permitted in the Constitution, it is better for the collective farmers to become individual smallholders." His words found sympathetic ears, as some of the collective farmers reportedly ran away from the "Sower" collective farm, destabilizing it. ${ }^{13}$ Likewise, P. I. Nekrasov and M. T. Kharin, kulaks who had been deprived of rights, told people in their village that, under the new Constitution, all those who had been deprived of rights would have full citizenship rights restored. Hence it was not necessary to fulfill any obligations to the state and all arrears to the state were going to be withdrawn. ${ }^{14}$ Additionally, suggestions to form trade unions among the collective farmers were rejected as anti-Soviet, because trade unions had on occasion posed challenges to the state by agitating for greater rights for unionized workers. ${ }^{15}$ Such interpretations of the draft Constitution could have had real consequences because they challenged the collectivized agricultural system that the state had worked so hard to create.

For similar reasons, local officials and the NKVD also labeled pro-religious interpretations of the draft Constitution as anti-Soviet. Discussion organizers and the NKVD carefully documented comments such as those made by S. A. Korobintsyn, the accountant at the Kumenskii raion communications section who wanted to add the right to engage in religious propaganda following the phrase, "freedom of antireligious propaganda." 16 Despite almost two decades of sustained state repression, the church apparatus remained more or less intact. So when people like Semina, a female worker at the "Stasovoi" artel, ${ }^{17}$ stated that, "in the draft Constitution it is stated about the freedom to leave religious cults, however, everywhere they close churches even though the majority of the population is against it," 18 local, regional, and central state and Party officials took notice.

In Sanchurskii raion, several religious people allegedly challenged communists in local positions of power. The chairman of the Zaozerskii rural soviet, comrade Mykhin, faced opposition from locals, who in one report were described as simply individual smallholders. ${ }^{19}$ However, a different report portrayed the culprit as a religious fanatic and smallholder (религиоз ный фанатик-единоличник) who interpreted the draft Constitution to mean that during the election campaign, it was permissible and even necessary to push priests into the membership of the rural soviet. ${ }^{20}$ Additionally, multiple sources record that Abramovich, a member of the Sanchurskii church, addressed the raion executive committee about having religious processions without the approval of the organs of power "on the basis of the draft Constitution." ${ }^{21}$ Such interpretations of the draft Constitution challenged, however indirectly, well-known state policies, including the collectivization of agriculture, the use of taxation to encourage collectivization, the closing of churches, and the active struggle against religion. While such incidents were rare, their challenge to established state policies qualified them as "class enemy interpretations" rather than "mistaken" interpretations.

Most of the "anti-Soviet" activity in the Kirov region was limited to words. Only in Votkinskii raion was violence directed against members of 
the collective farm administration or Party members. A report to the TsIK lists several violent incidents, citing the sharp struggle between class enemy elements and the local aktiv as the precipitating factor for such acts. On the "Niva" collective farm, "class enemy elements" stabbed the deputy chairman of the collective farm and threw him in the river (зарезали и бросил в реку). During a meeting of the "17th Party Conference" collective farm, someone burned down the apartment of the collective farm chairman, comrade Shkurikhin. ${ }^{22}$ There was also a case of arson on the "Red Hill" collective farm in Balanyrinskii rural soviet. The district executive committee there alleged that, in connection with the low grain harvest in the raion, kulaks disseminated rumors about the difficulties with grain and urged the dismantling of collective farms. On the "Excavator" collective farm, an individual smallholder, Sobin, angry about his agricultural taxes, beat up Comrade Romanov from Upolnomochennskii rural soviet ${ }^{23}$ and attacked a female tractor driver ${ }^{24}$ Given the localized nature of such violent behavior, it seems likely that local conditions, perhaps connected with the poor harvest in 1936, triggered such violent acts.

The fact that the same incidents, anti-Soviet rhetoric, and critical interpretations of the Constitution were used in multiple reports to the Central Executive Committee suggests that "anti-Soviet" behavior was unlikely to have been a widespread problem in the Kirov region. Moscow's soliciting of such information is more likely a reflection of central anxieties than mounting local threats. Despite their relative rarity, reports on "anti-Soviet" activities reinforced central anxieties about the intentions or activities of class enemies. Anxiety about class enemies and their potential to exercise the new rights that the 1936 Constitution gave them intensified as the preparations for local elections at the end of 1936 and the 1937 elections to the Supreme Soviet unfolded. Some local officials feared that these new rights provided the formerly disenfranchised with a way to enter local organs of power and to promote their own agendas.

\section{The ratified Constitution and the elections of 1937}

Despite reports of anti-Soviet activity during the popular discussion of the draft and widespread popular disapproval of the expanded franchise, Stalin defended his decision to grant universal suffrage. In his speech on the draft Constitution made at the 8th Congress of Soviets in December 1936, Stalin reiterated his argument that the Soviet state had deprived "dangerous elements" of voting rights during a time when they were waging open war against the people and undermining Soviet laws. But now that the exploiting class had been destroyed and Soviet power had strengthened, the time to introduce universal suffrage had come. He countered the argument that universal suffrage would allow enemy elements to worm their way into soviet organs of power ${ }^{25}$ by replying that not all former kulaks and white-guardists were harmful to Soviet power, and, if the people somewhere elected 
dangerous people, it would mean that the agitational and propagandistic work was not effectively carried out. ${ }^{26}$

While some in the central leadership may have been convinced that full democracy was a viable option, the language in reports on election preparations from Kirov's Regional Party Committee and district Party organizations suggests that, like its citizenry, Kirov's regional and local officials were unsupportive of full citizenship rights for former class enemies. Although the number of incidents may have been few, it appears that local officials saw them as harbingers of disorder. They felt that the former lishentsy were undermining Soviet authority, particularly in the countryside. ${ }^{27}$ Getty has argued that such sentiment was part of a national trend as "the regional leaders felt that anti-Soviet feeling was strong enough in the country to threaten Party control, and open elections would give it voice. They resisted the new voting system from the beginning." ${ }^{28}$ Reframing the formerly disenfranchised as "class enemies" may have served as a way for local and regional officials to undermine the new voting system.

It is unclear from the documentary evidence from the Kirov region just how strongly the regional and local leadership opposed the new voting system or what steps they may have taken against it. However, minutes of the meeting of the Murashinskii district NKVD Party cell suggest that local officials did not share Stalin's belief that re-enfranchising such people would not result in increased enemy activity. This meeting followed on the heels of the 8th Congress of Soviets, in December 1936, at which the Constitution was ratified and Stalin dismissed concerns about class enemies using the Constitution to their own ends. However, the atmosphere at this local Party meeting was far less optimistic. Comrade Zabodkin spoke on the question of the elections and of those formerly deprived of voting rights. In the past, he noted, the class enemy wormed themselves into the Soviet organs and now could do so again, particularly where there would be poor preparatory work for the elections. ${ }^{29}$ Therefore, Zabodkin opined, we must know the class enemy's plan and stop it promptly. Comrade Zherekhov said that in connection with the new system of elections to the soviets, the harmful elements would of course attempt to use this opportunity to give their vote to their people. The task of monitoring harmful elements placed a great responsibility on Party members and the NKVD, particularly those sections in which one or another communist works. ${ }^{30}$

Despite some local officials' doubts, the central leadership maintained its stance on expanded election rights well into August 1937. In the protocol of the general Party meeting of the Nolinskii district Party cell of the NKVD from August 12, 1937 on the topic of elections, the assembled NKVD members noted that:

All members and candidate members of the All Union Communist Party, [should] not allow the violation of the Stalinist Constitution, and quickly quash any violation of the Constitution regardless of who 
they are, but particularly on the part of workers of the District Party Committee. $^{31}$

This sort of directive implied that the state was serious at least through August about maintaining the electoral standards set forth in the Constitution. But it is interesting to note that the meeting seemed especially concerned that "workers of the District Party Committee," that is, local Party members, might be the ones who violated the Constitution. However, the increasing pressure from local and regional officials in the face of what the latter regarded as serious efforts by anti-Soviet elements to gain a foothold in local organs of power influenced how the central leadership dealt with the question of open and multi-candidate elections.

Reports from the Kirov region in early 1937, undoubtedly issued in response to a central directive, consistently noted anti-Soviet and counterrevolutionary incidents following the ratification of the Constitution and the extension of citizenship rights to the formerly disenfranchised. The intensity of reported anti-Soviet enemy activities varied dramatically, ranging from reported rumors to outright agitation. In Ziuzdinskii district, the District Party Committee reported that harmful elements prepared for the elections to the Supreme Soviet and the lower soviet organs. Their reportedly harmful work was conducted in differing ways, including individual statements, underground meetings, and writing slogans against Soviet power on trees in the forest and on tablets. ${ }^{32}$ These incidents were used as straw men to inspire increased agitation and propagandistic work before the elections. A report about preparation for the elections to the Supreme Soviet noted that agitprop instructors had intensified their work because the counter-revolutionary elements used districts where political work was weak or absent to conduct anti-Soviet campaigns. ${ }^{33}$

While in some cases enemy activity may have simply been a foil for increasing Party work, there were incidents of "enemy activity" that were genuinely threatening to local order. In the village of Kora, the former head of the collective farm, Fir Ovsizhnikov, agitated for the elimination of pig farms, incited the collective farmers to divide up the pigs, ridiculed animal husbandry, and called rabbits Soviet sheep and goats Soviet cows. He agitated against communists, saying, "on the collective farm it is possible to allow one communist for breeding and remove his eyes ..." ${ }^{34}$ Although it is unclear what exactly he meant, his intent is clear. In the view of local officials, Ovsizhnikov's hostility towards the state and its policies, and his veiled threats of violence towards its representatives in the countryside, posed a potential threat to state control and local stability that was made more dire by the pending elections.

It is undeniable that some former class enemies exploited the weakness of the state in the rural areas to return to positions of power. Noskov, a former kulak from the village of Kir'ia, who had become chairman of the rural soviet, allegedly told a local candidate, "if you [the candidate] 
will work for us [Noskov and his supporters] then we will vote for you under the new Constitution, but if you will not be with us, then we will not vote for you." ${ }^{35}$ Noskov was chairman of the rural soviet, despite his past as a kulak, and undoubtedly wielded some power in the district. His statement makes clear that he intended to use his influence and position to see that people who shared his interests rather the state's would be elected. Further defiance of the state's power and subversion of its interests came from others in Ziuzdinskii district. Under collectivization, collective farmers had to pay taxes, but individual smallholders had to fulfill additional state obligations because of their individual status; these extra burdens on them were part of the way that the state encouraged people to collectivize. However, with the ratification of the Constitution and the proclamation of equal rights, these individual smallholders refused to pay what they viewed as discriminatory taxes. Some of the individual smallholders of Kharinskii rural soviet (I. K. Ichetovkin, Sh. S. Kazakov, and others) categorically refused to fulfill any state obligation, arguing that the Constitution guaranteed the equal rights of all citizens. ${ }^{36}$ Such incidents posed threats to the already over-taxed local administrators trying to keep order in the countryside.

In addition to challenging or subverting state control in the countryside, others used the election meetings and their new constitutional rights to express dissatisfaction with state policies and the state itself. On one collective farm in Iaranskii district, a collective farmer urged people to vote against Stalin because he "takes bread from us and it is necessary to vote for someone who will not take bread." ${ }^{37}$ In the village of Kozlakh, rumors circulated that on the 12th of December in Moscow, there would be a different administration, life would be better, and the collective farms would be dissolved. In the village of Polom, in the same district, Paraskovia Plastinina stated that "we will vote for the Antichrist." ${ }^{38}$ Such incidents suggest that some people still felt that their lives would be better without Soviet power, to the point that some people felt the Antichrist was preferable. These dissatisfied citizens hoped the upcoming elections would reverse the more onerous Soviet policies or result in a complete regime change.

Others took a less extreme approach in demonstrating their dissatisfaction with the Soviet regime by focusing on questions of democracy, the violation of the new Constitution, and regulations of elections. For example, a telegram from the Kirov Regional Party Committee addressed to Stalin himself noted that in a number of districts, there were questions and speeches in meetings about how the registration of only one candidate per seat in the Soviet of the Union undermined the democratic nature of the electoral laws. ${ }^{39}$ Others took it a step further and declared the elections illegitimate because they violated the rules that the state itself had set forth. For example, in Omutninskii district, after comrades Stalin, Andreev, Litvinov, Budennney, and Rodin did not give their approval to being placed on the ballot in Omutninskii voting district, there remained only one candidate on 
the ballot for the Soviet of the Union and the Soviet of Nationalities. The chairman of the district voting committee reported that "enemies of the people" took advantage of this situation and spread rumors that it was useless to go to the elections because without two candidates it meant that the regulations on elections had been violated and that democracy did not exist. The author noted that, in response, agitators were organized to explain that this assertion was false and reportedly an unknown party beat up the rumorspreading "enemies." 40

Many reports from district Party committees ascribed incidents of counter-revolutionary activity to the ratification of the new Constitution. A report from the Ziuzdinskii District Party Committee noted that "the complete facts demonstrate that, in connection with the approval of the Stalinist Constitution, the counter-revolutionary activity of harmful elements, particularly of clergymen has revived in Ziuzdinskii district." ${ }^{41}$ Those in attendance at the March 20,1937 general Party cell meeting of the Nolinskii district NKVD reached a similar conclusion. Party members noted that the new electoral system and the Constitution gave the opportunity for harmful elements to participate in elections and to be elected. Therefore, it concluded that the Party organization as a whole and every member of the Party individually must conduct mass political work among the population in order to exclude alien people from the soviets. ${ }^{42}$ At the previous (February 19) meeting of the Nolinskii Party cell of the NKVD, comrade Kolomytsev stated that:

the approved new Stalinist Constitution gives the right to vote to all adult citizens, with the exception of those deprived of the right to vote by the court. Several counter-revolutionary groups, particularly members of different types of cults, are using these laws to begin carrying out anti-Soviet agitation. They conduct this agitation not only among those of advanced age, but they also draw in the youth. ${ }^{43}$

Whether rooted in long-established Soviet trends or the prejudices, fears, or personal experiences of local officials, members of already suspect groups, such as former kulaks and members of the religious establishment, were often named as the perpetrators of counter-revolutionary activities. For example, at a 1937 pre-election meeting on the "Country of the Soviets" collective farm, a drunken administrative exile, N. P. Shestakov, allegedly created an uproar by shouting counter-revolutionary statements before being arrested. ${ }^{44}$ In Shabalino, during the electoral discussion, a former kulak, Ustiuzhanov, stated: "you can write down any growth figure you want, maybe having grown not 16 tsenters $(1600 \mathrm{~kg})$ but more. It is all self-delusion." He was reportedly rebuffed by a 65 -year-old collective farmer who said: "Blockhead, if you could be taken back 40 years, we grew only 2-3 tsenters of potatoes on one hectare, but now hundreds grow from collective farm land and there is the wonder." ${ }^{45}$ In both cases, the complainants' pasts 


\section{The Constitution, elections, \& repression}

were important. The comments both men made caught the attention of local officials because of their past, while similar comments made by upstanding citizens were treated as complaints to be refuted rather than subversive actions.

Likewise, local and regional officials often portrayed clergymen and religious believers as real threats to local power. For example, a report from Ziuzdinskii district notes that the harmful anti-Soviet work of the clergy was concentrated primarily in three or four rural soviets where all churches had been closed but the clergy still had influence which they used to promote religion in these areas. According to the chairman of the Ziuzdinskii District Party Committee, Batyrev, in March 1937, the Bishop Zhuravlev, living in exile near the city of Omsk, charged the priest, Samodurov (from Vereshaginskii district, Sverdlovsk oblast'), to work with the priests of the city of Omutninsk "to perform religious rites for the believers." Upon the priests' arrival, former kulaks, individual smallholders, and some of the collective famers of the Ivanovskii, Kir'ianskii, and other collective farms gathered around them. The clergymen focused their work on the opening of churches. An individual smallholder from the village of Kuvakushska, Sidorov, who was also a former psalm reader, headed up this work. Reportedly, there had already been repeated endeavors to collect materials and money, and Noskov, ${ }^{46}$ a former kulak and chairman of the rural soviet, acted as the keeper of such funds. Additionally, these religious supporters also reportedly conducted preparations for the elections to the Supreme Soviet. Batyrev and other local administrators felt very threatened by their actions. ${ }^{47}$

All of these incidents culminated in local officials adopting a siege mentality in the second half of 1937 . For example, a report from Omutninskii district listed a number of anti-Soviet acts that had taken place during the elections to the Supreme Soviet:

1 In Kirs, the clergy worked very strongly to spread rumors that those who went to the elections would also be voting for the closure of churches.

2 In the 19th voting district in the city of Omutninsk, someone wrote on one voting bulletin, "we want Aleksander Kerensky, we want Trotsky."

3 In the 26th voting district, someone wrote on one bulletin, "you will vote against your will for our candidates when there are no other candidates."

4 In Uninskii district, there was an incident when in several separate bulletins it was written: "I vote for Jesus Christ."

5 In the city of Omutninsk, on the evening of the elections, there arrived from the Urals an unknown worker who stayed with Anton Nikolaevich Loginov in building 40 on Komsomol Street. When the agitator arrived, this unidentified worker answered, "that if you will go to the elections with us then I won't go. The electoral system is incorrect and I don't agree with it. Our elections in the Urals don't proceed in this manner." 48 
In reaction to this list, the chairman of the district election commission, Riakin, concluded that there were many enemies and that "they must be fished out and destroyed." ${ }^{49}$ Riakin's comments suggest a shift towards viewing "counter-revolutionary events" perpetrated by former class enemies as part of an organized network, which needed to be rooted out and destroyed, rather than being the isolated acts of individual "class enemies." Such a change in perception can also be found in the NKVD Party cell meeting protocols.

Minutes from the local NKVD Party cell meetings in the early months of 1937 demonstrated a belief that, while it was dangerous to allow the participation of the formerly disenfranchised, the situation could be managed with proper vigilance. At the March 10, 1937 closed meeting of the Falenskii District NKVD Party cell, comrade Bystrov stated:

According to the Stalinist Constitution the up-coming elections will allow the participation by cult members, former White Guardists, Kulaks and others. They will not only vote but they can also be elected. In order to not exclude communists from the soviets, we [the NKVD and the Party] need to be exceptionally vigilant and to develop work among the masses. But I believe that among us in the Party organization not everyone has studied the Constitution, for example, Smetanin, who is the leader of the militsia, even though he is laden with work, it is necessary for him to study. ${ }^{50}$

Other calls for increased mass work and vigilance came from the Sovetskii district NKVD. At a closed meeting on March 9, Comrade Polushin noted that it was necessary to further explain the Stalinist Constitution so that there would be no violations of democracy during the elections to the Soviets. At the same meeting, when the question of former people participating was posed, Comrade Kasbianov cited Stalin's answer, "It is necessary to work, not to complain (хныкать)," to those who suggested limiting the rights of the former class enemies so they did not infiltrate state offices, reiterating the central leadership's assertion that any remaining anti-Soviet sentiment could be managed with appropriate mass work. ${ }^{51}$

Concern about the elections being used to benefit class enemies and the need for increased vigilance dominated the March 25 meeting of the Kaiskii NKVD Party cell. Comrade Agafokov opened the meeting stating, "on the basis of the new Constitution class enemies will meddle in the conduct of our work, and based on that we must be vigilant." ${ }^{52}$ Several of his colleagues echoed his concern. Comrade Vladimirov noted that, "the re-elections of Party organs on the basis of the new Constitution will proceed by secret ballot voting. Taking advantage of this, class enemies might worm in as deputies in the rural soviets. Therefore we must have revolutionary vigilance..." ${ }^{53}$ Comrade Uiferev argued that:

on the basis of the new Constitution, the decision of the Central Committee specifically touched upon the question about revolutionary 


\section{The Constitution, elections, \& repression}

vigilance and being ready for new re-elections. But we are poorly prepared and the class enemies are preparing better than us, they will try to use this new Constitution to force in their deputies to the Soviets. Right now in this place of exile, settlers declare that if the new Constitution doesn't give us passports, ${ }^{54}$ we will run away. Now there were some people who ran away, but in Biserovskii district the chairman of the rural soviet doesn't chase after the run-aways." ${ }^{55}$

Uiferev provided specific examples of class enemies actively engaging the state and using the language of the new Constitution to agitate for greater rights. His fellow Party member, Khlust'ianov, offered further illustrations that the agitation of class enemies on the basis of the new Constitution was not just the imaginings of a paranoid state. He reported that "on the basis of the new Constitution, Kulaks come and say-we need passports, if we will elect deputies in the oblast' then how can we go without passports." ${ }^{56}$ The members of the Party cell concluded that "the presence of class enemy elements in our district, who received citizenship rights under the new Constitution, present our Party organization with the task of the further strengthening of vigilance, the unmasking of the schemes of class enemies, [and] remembering the words of Comrade Zhdanov at the plenum of the Central Committee, that the enemy is acting among us, thoroughly preparing for the election." ${ }^{57}$ Presented with concrete examples, the language of the protocols of the district NKVD Party meetings changed. Class enemies exploiting their new rights against the state and worming their way into organs of power was now no longer just a possibility, something that might happen if the Party did not conduct adequate work among the masses; these were now facts that forced the local NKVD and Party to take action. ${ }^{58}$

As the elections approached, the language became increasingly belligerent, and one sees a tendency to dehumanize those labeled as class enemies. A participant at the July 25 Zuevskii district NKVD cell meeting stated:

Comrades, I would like to remind you that our collective in the upcoming election campaign must be more vigilant than ever or the class enemy will begin to put out his tentacles. As we know from the press, using the broad rights of the new Constitution, members of religious sects, priests and other henchmen (прихвостень) conduct a hidden struggle. They want to defame our best people so they won't get into the organs of administration of Soviet power..$^{59}$

As the concerns about class enemies evolved, their alleged goals became more concrete: to occupy the local positions of power themselves and to destabilize the Soviet system. This alleged change spurred Soviet officials at all levels to accept the existence of such an organized and highly-motivated sleeping enemy in their midst. 
Of all the activities in which former kulaks and clergymen engaged, the agitating for and electing their own candidates was the most disquieting for the central leadership and most directly threatening to local leaders. For example, in the village of Rodygino, the Regional Party Committee reported Rodygin, a Trotskyist who had been purged from the Party, agitated for the nomination of class-alien people to the Supreme Soviet. ${ }^{60}$ In the village of Natiunicha, S. A. Chiudinovskikh stated, "here is the priest Filip'ev, who has a higher education, maybe he should be elected to the soviet." ${ }^{61}$ And on occasion, the fears of the Party and state leadership were realized when, in local elections, former class enemies were indeed elected to positions of power. At a NKVD cell meeting, comrade Kozel noted that many people did not understand the power of the secret ballot very well, as evinced by their election of delegates to professional organs, but class enemies seemed to understand that power as former kulaks were elected. ${ }^{62}$

Given popular opinion on the re-enfranchisement of the formerly disenfranchised, the struggle for governance in the countryside, and NKVD reports, it is doubtful that local and regional officials in Kirov ever believed that restoring voting rights to former kulaks and clergymen was a viable option. However, central Party and state leaders pushed regional and local officials to support and attempt to implement the expanded electoral process outlined in the Stalinist Constitution and the subsequent "Regulations on Elections." This policy change meant reclassifying former class enemies as full citizens. However, their new status quickly eroded as regional Party, state, and NKVD reports detailing anti-Soviet activity were sent to the Central Committee. These reports began to consistently associate these activities with the formerly disenfranchised and offered increasingly specific incidents even though the numbers (at least from Kirov) of the incidents were limited. At the same time, NKVD Chief Yezhov was pushing for increased vigilance, ${ }^{63}$ a sentiment that was quickly picked up by the lower NKVD organs. By mid-year, the complete certainty of the NKVD organs, even at the lowest level, that class enemies were worming into local organs of power during the election period, combined with reports of anti-Soviet activities from various provinces, contributed to the decision to unleash mass arrests of "anti-Soviet" elements beginning in July 1937. The intensification of repression against such groups only escalated after that.

The ratification of the 1936 Constitution contributed to repression in 1937 as local anxieties deepened because of the increasingly strident rhetoric coming from Party leaders and, as Getty argues, anxieties and pressures from the regions convinced the center that the threats were real. The increased reports of enemy activity both reflected and contributed to an overall state of anxiety about enemy activities in this period. These reports and the evidence that they offered no doubt influenced the central leadership's decisions to repress certain segments of the population. 


\section{Notes}

1 Similar cases are examined in the Ukraine by I. E. Smirnova. She discusses cases of the formerly dekulakized demanding their land be returned to them from the collective farms that seized it: "Otrazhenie 'kulatskoi operatsii' v dokumentakh partiinykh organov Donetskoi Oblasti," Stalinism v Sovetskoi Provintsii: 1937-1938 massovaia operatsiia na osnove prikaza, No. 00447, 673-716.

2 For more on the effects of the economic crisis and its causes, see: Roberta Manning, "The Soviet Economic Crisis of 1936-1940 and the Great Purges" in Stalinist Terror: New Perspectives, eds. J. Arch Getty and Roberta T. Manning (New York: Cambridge University Press, 1993), 117-141.

3 J. Arch Getty and Oleg Naumov provide a detailed account of how failure to correctly verify Party documents in the wake of the Kirov assassination helped trigger the repression of Party members in 1936 in The Road to Terror: Stalin and the Self-Destruction of the Bolsheviks, 1932-1939 (New Haven: Yale University Press, 1999).

4 GARF, f. R-3316, op. 8, d. 222, 1. 39.

5 Getty's works on the topic include: The Road to Terror (with Oleg Naumov); "'Excesses Are Not Permitted': Mass Terror and Stalinist Governance in the Late 1930s," Russian Review, Vol. 61, No. 1 (Jan. 2002), 113-138; and "Preelection Fever: the Origins of the 1937 Mass Operations" in James Harris, ed., Anatomy of Terror: Political Violence under Lenin and Stalin (Oxford: Oxford University Press, 2013).

6 For example, Egor Avdeevich Gontsov, a Komsomol member, was verbally rebuked and his critique of the USSR tackled head-on by the chairman of the rural soviet, comrade P. S. Khodyrev; chairman of the collective farm, N. A. Goiatsov; and other collective farmers in attendance. Similar challenges to politically incorrect statements were noted in a report to the Central Committee's political administration.

7 "Bolshevik," collective farm, Ankushinskii rural soviet, Kirovskii raion, GASPI KO, f. 1255, op. 2, d. 394, 1l. 114-117.

8 "Unified Labor" collective farm, Viazovskii rural soviet, Kirovskii raion, GASPI KO, f. 1255, op. 2, d. 394, 1l. 36-40. This anecdote also appears in GASPI KO, f. 1255, op. 2, d. 394, 11. 114-117.

9 GAKO, f. 2168, op. 1, d. 474 l. 122.

10 GASPI KO, f. 1255 , op. 2, d. 394, 1. 11 .

11 GASPI KO, f. 1293, op. 2, d. 43, 1. 26.

12 The "Sower" collective farm, first Kliuchevskii rural soviet.

13 GAKO, f. R-2168, op. 1, d. 472, 1. 17.

14 N. Lemanovskii rural soviet, Ziuzdinskii raion, GASPI KO, f. 1255, op. 2, d. 394, 1l. 114-117; this incident is also reported in GAKO, f. 2168, op. 1, d. 473, 1. 50 and GAKO, f. R-2168, op. 1, d. 474, 1. 132.

15 Vylegzhanin, a collective farmer from Kashylinskii rural soviet, Nagorskii raion, made a suggestion "about the organization of professional unions on the collective farms," GASPI KO, f. 1255, op. 2, d. 394, 11. 114-117. This anecdote is also recorded in GASPI KO, f. 1255, op. 2, d. 394, 1l. 36-40. A similar suggestion came from Kaiskii raion, where the bookkeeper on the Dzerzhinskii collective farm, E. P. Istomin, suggested giving the right to collective farms to create professional unions for agricultural workers. GASPI KO, f. 1255 , op. 2, d. 394, 1l. 114-117.

16 GASPI KO, f. 1255, op. 2, d. 394, 11. 114-117; this anecdote is also recorded in GASPI KO, f. 1255 , op. 2, d. 394, 1. 36-40.

17 In the city of Kirov. 
18 GASPI KO, f. 1293, op. 2, d. 43, 1. 26.

19 GASPI KO, f. 1255, op. 2, d. 394, 1l. 114-117.

20 GAKO, f. R-2168, op. 1, d. 473, 1. 50.

21 GASPI KO, f. 1255, op. 2, d. 394, 1l. 114-117; this incident is also reported in GAKO, f. R-2168, op. 1, d. 473, 1. 50, and GAKO, f. R-2168, op. 1, d. 474, 1. 26.

22 GASPI KO, f. 1255, op. 2, d. 394, 11. 114-117.

23 GAKO, f. R-2168, op.1, d. 473, 1. 50. The murder of the deputy chair of the collective farm and the burning of Comrade Shkurikhin's apartment are mentioned in this report as well.

24 GAKO, f. R-2168, op. 1, d. 474, 1. 338. This report also contained the story of the deputy chair's murder, the two arsons, and the rumors spread by kulaks.

25 J. Arch Getty, “'Excesses Are Not Permitted': Mass Terror and Stalinist Governance in the Late 1930s," notes these complaints were also frequent from regional Party leaders, who resisted the implementation of a multi-candidate system from its inception (see also "Pre-Election Fever: The Origins of the 1937 Mass Operations”). This comment therefore could be seen as a subtle way of checking their resistance.

26 Pravda (November 28, 1936), 4.

27 The weakness of the Soviet state in the countryside had long been a problem, causing a great amount of frustration as the center tried to implement its plans and campaigns in places where its representatives were few and often outnumbered. Because the state was weakest in the countryside, the countryside was seen as the most vulnerable place for the infiltration of anti-Soviet elements. For further information on the weakness of the state and Party apparatus in the countryside, see: J. Arch Getty and Oleg Naumov, The Road to Terror: Stalin and the Self-Destruction of the Bolsheviks, 1932-1939 (New Haven: Yale University Press, 1999); Charles Hier, "Party, Peasants and Power in a Russian District: The Winning of Peasant Support for Collectivization in Sychevka Raion 1928-1931," (unpublished dissertation, University of Pittsburgh, 2004); Lynne Viola, Best Sons of the Fatherland: Workers in the Vanguard of Soviet Collectivization (New York: Oxford University Press, 1987); Roberta Manning, "Government in the Soviet Countryside in the Stalinist 1930s: The Case of Belyi Raion in 1937," The Carl Beck Papers in Russian and East European Studies, No. 301 (University of Pittsburgh, 1984).

28 Getty, "Pre-election Fever: The Origins of the 1937 Mass Operations."

29 Information on the worming in of class enemies exists in other reports on explanatory work in different spheres in 1937, including a report on health services and disability payments: GASPI KO f. 1290, op. 1, d. 290, 1. 167.

30 GASPI KO, f. 861, op. 1, d. 145, 1l. 67-68.

31 GASPI KO, f. 790, op. 1, d. 201, 1. 54.

32 GASPI KO, f. 1290, op. 1, d. 56, 11. 120-121.

33 GASPI KO, f. 1290, op. 1, d. 61, 1. 18 .

34 Barminskii rural soviet, Zuevskii district, GASPI KO, f. 1290, op. 1, d. 61, 11. $18-27$.

35 Kolychevskii rural soviet Ziuzdinskii district, GASPI KO, f. 1290, op. 1, d. 56, 11. $120-121$.

36 GASPI KO, f. 1290, op. 1, d. 56, 1l. 120-121.

37 GASPI KO, f. 1290, op. 1, d. 61, 11. 18-27.

38 Verkhoshizhemskii district, GASPI KO, f. 1290, op. 1, d. 61, 1l. 134-135. This is reminiscent of reports about collectivization as cited in Lynne Viola, "The Peasant Nightmare: Visions of Apocalypse in the Soviet Countryside," The Journal of Modern History, Vol. 62, No. 4 (Dec. 1990), 747-770.

39 GASPI KO, f. 1290, op. 1, d. 61, 1l. 134-135. 
40 GASPI KO, f. 1290 op. 1, d. 56, 1l. 122-124.

41 GASPI KO, f. 1290, op. 1, d. 56, 1l. 120-121.

42 GASPI KO, f. 790, op. 1, d. 201, 1. 26.

43 GASPI KO, f. 790, op. 1, d. 201, 1. 12.

44 Gostevskii rural soviet, Kotel'nicheskii district, GASPI KO, f. 1290, op. 1, d. 61, 1l. 18-27.

45 GASPI KO, f. 1290, op. 1, d. 61, 1l. 18-27.

46 This is the same abovementioned Noskov, who was the chairman of the rural soviet and former kulak.

47 Kuvakushskii, Afonas'tvskii, Kolychevskii, and Evzhinskii rural soviets, Zuizdinskii district, GASPI KO, f. 1290, op. 1, d. 56, 11. 120-121. Batyrev himself was deemed an enemy of the people and charged by the Kirov Regional Procurator under article 58, paragraphs 7 (wrecking) and 11 (being a member of a wrecking organization, but seems to have escaped jail time, going on to serve in World War II with distinction.

48 GASPI KO, f. 1290, op. 1, d. 56, 11. 122-124.

49 GASPI KO, f. 1290, op. 1, d. 56, 11. 122-124.

50 GASPI KO, f. 2158, op. 1, d. 7, 1. 9.

51 GASPI KO, f. 1460, op. 1, d. 236, 1. 4. Similar calls for vigilance were also present in the protokoly from the closed Party meeting on January 29, 1937.

52 GASPI KO, f. 1922, op. 1, d. 164, 1. 8.

53 GASPI KO, f. 1922, op. 1, d. 164, 1. 8.

54 The Soviet Union began issuing internal passports in the 1930 s as a way to control movement, particularly in rural areas, and keep collective farmers on the farm. It was much more difficult for them to obtain passports than it was for workers. In this case, deported people want passports, which would free them up to travel unhindered about the USSR.

55 GASPI KO, f. 1922, op. 1, d. 164, 1. 8.

56 GASPI KO, f. 1922, op. 1, d. 164, 1. 9.

57 GASPI KO, f. 1922, op. 1, d. 164, 1. 10.

58 While specific incidents in the District Party Committee and Regional Party Committee reports are harder to date because these reports are compilations from various sources, it would appear that by March, "anti-Soviet" activity was reported to the District Party Committee, and as the election campaign wore on, these reports became more frequent. Most of the Regional Party Committee reports to the TsIK were issued in the latter half of the year. Whether or not this is when more anti-Soviet acts occurred, this is when the Regional Party Committee, and more importantly, the TsIK, began to receive such reports in volume.

59 GASPI KO, f. 1331, op. 2, d. 108, 1. 41.

60 Sovietskii district, GASPI KO, f. 1290, op. 1, d. 61, 11. 18-27.

61 Verkhovinskii district, GASPI KO, f. 1290, op. 1, d. 62, 1. 22.

62 GASPI KO, f. 1922, op. 1, d. 164, 1. 33.

63 For more on Yezhov's policies, see: David Shearer, Policing Stalin's Socialism: Repression and Social Order in the Soviet Union, 1924-1953 (New Haven: Yale University Press, 2009); and J. Arch Getty, “'Excesses Are Not Permitted.’” 


\section{Conclusion}

Stalin's Constitution utilizes the discussion of the draft Constitution to examine the discourse between the central state leadership and citizens as well as the limitations of central power. For the central leadership, mobilizing its citizenry in a variety of state-building campaigns was the main goal of the discussion of the draft Constitution. Central state actors tried to develop enduring institutional forms for territorial administration, military-coercive power, revenue extraction, and other socioeconomic functions through such campaigns. However, the goals of the central leadership at times stood in stark contrast with the people's expressed interpretation of that social contract. Citizens of the USSR focused on securing rights and privileges, often related to improving their daily lives, from the central government, but also made known their support of and opposition to aspects of the draft Constitution.

Employing a regional case study, in this case, of the Kirov region, has enabled a tight focus that establishes the local context in order to understand why citizens made the suggestions and had the reactions that they did to the draft Constitution. This approach reveals quite clearly the mechanisms put in place for a discussion of the draft Constitution and the problems of implementation of central decrees at local and regional levels. It also allows for the examination of the varied responses to the discussion and popular suggestions by distinct governing and Party organs at the local and regional level. Regional studies like this one demonstrate that Soviet citizens had agency. They often shrewdly sought to manipulate state goals, rhetoric, and campaigns to their own ends. But as this study argues, the population of the Kirov region did not always speak with one voice. Urban residents and rural residents often had divergent views, as did local elites and the local population, and at times so too did different generations.

However, the central leadership's view of constitutional theory in the USSR and how it used this theory to formulate the draft constitution had a profound effect on the discussion. Stalin and the central state leadership initiated a popular campaign, and the popular response that followed revealed much about how the people of the USSR conceived of the role of state and 
citizen, and the latter's role in constructing socialism. Soviet leaders decided to rewrite the Constitution for several reasons, the most important of them and the ones about which they spoke publicly being: the class enemies had been vanquished; it was time to expand the franchise; and the state needed citizens' active participation to enhance the construction of Soviet socialism. Additionally, rewriting the Constitution represented an important step in modernizing the Soviet state as a state, by creating a uniform central code of laws and establishing a social contract between the state and the citizens.

The central leadership did not view single-party rule and popular participation as antithetical. Indeed, leaders encouraged popular participation, within a strict framework, as a way to strengthen social and economic development in the USSR. The redefinition of citizens and citizenship, which included the re-enfranchisement of former priests and kulaks, as well as its focus on state building, illustrate how the central state sought to create a new social contract with its citizens and what it expected from them in return. The direction that the central leadership tried to give to the popular discussion reflected the changes that the central leadership hoped to bring about: a more participatory society within a one-party state, and a culture with the shared purpose of building a socialist society. These expectations were reflected in the narrative that the central authorities set forth in recommended lesson plans and newspaper articles.

While the central leadership envisioned a people devoted to selflessly building socialism, the people of the Kirov region had a somewhat different set of expectations. They believed that they should exercise more local control over an array of issues and that the state should provide them with increased material benefits because of the sacrifices that they had made and expected to make for a while longer. Many of the popular suggestions that came out of the Kirov region, especially its collective farms, were personal and local: they focused on citizens' rights, access to social welfare programs, local power, and safety and security. The people of the Kirov region embraced some state programs because they were beneficial to their everyday lives, and they rejected others. But they always used the language of the discussion and state-building, as articulated by Moscow, to frame and legitimate their requests. Their comments and suggestions often made references to the principles, such as equality, enunciated in the draft Constitution.

This study has argued that many of the citizens of the Kirov region, especially the collective farmers, participated in the public discussion and used the opportunity to express their concerns and their pride. The peasant participants in this study defy easy stereotype. They were neither sullen nor docile. Although not highly literate, they valued the promises of education. They were politically astute in various ways. Many appreciated the changes that the revolution had brought, but they were still critical of certain policies. As this study suggests, local or regional studies are essential if we are to understand local concerns, especially those of the collective farm system and collective farmers. 
As the popular discussion indicated, Kirov's citizens-and presumably many citizens across the USSR - reacted to the draft in complex ways. On the one hand, many applauded it for what it represented and promised. After all, a mere score of years earlier, there was no Constitution, nor were there citizens. But Kirov's residents' comments and suggestions convey what they wanted out of this social contract, and those needs were often very specific. Liberal conceptions of the rights of individuals are less evident than demands for more social control, especially at the local level. The class and social suspicions, often rooted in local experiences but fueled by central campaigns, that appeared in the popular discussion make clear that the USSR in the mid-1930s was still a society in formation.

The focus on local and personal interests demonstrates that underlying the common language that unified the central state's narrative and popular suggestions were often rather different interpretations of the rights and roles of the state and citizens. Many Kirov residents, for example, were critical of the proposed guarantees of habeas corpus, not on principle but because crime was a regular feature of rural life. Tensions such as these between the central state leadership's interpretation of the rights and duties of citizens, and citizens' interpretations, became more apparent when some of the recently enfranchised former people seized upon their new constitutional rights and began to set forth their own candidates, who advocated for their own interests in the subsequent elections. Reports of anti-Soviet activities in the region and instances of former people nominating their own candidates for local offices were often sent to Moscow, where these reports most likely served to exacerbate the anxieties of the central leadership.

The onset of mass repression in 1937, followed by the massive destruction of Soviet society during World War II, meant that some of the aspirations enunciated in the Constitution remained unfulfilled. But one should not dismiss the 1936 Constitution out of hand. The opening up of the electoral franchise, combined with a public forum for discussion, encouraged many Soviet citizens to engage the state in a dialogue, albeit a long-distance one, about their needs and responsibilities. At no point in this dialogue can we find any trace of Western liberalism. The draft Constitution, while granting many of the rights and freedoms found in Constitutions in Western Europe and North America, conveyed an entirely different vision of the role and function of a constitution. This was a social contract in a literal sense, one in which benefits and rights were specifically enunciated. The Soviet Constitution was a roadmap to a socialist society and a specific type of democracy-Soviet democracy. Given the influence of the 1936 Soviet Constitution, the lack of scholarly attention that it has received seems odd. The author hopes that this study will not be the only study of that foundational document and popular reactions to it, nor of the influence that it had on later Soviet and post-Soviet constitutions. As this study shows, such studies can provide keen insight into the desires and dislikes of the Soviet citizenry in the 1930s. 


\section{Notes on sources}

Most of the information in this work on both the implementation of the discussion and the popular response to the draft Constitution comes from regional and local Party and state documents. Many of these documents were designed to address certain questions and concerns raised by officials in Moscow. Mikhail Kalinin, the Chairman of the Central Executive Committee, was particularly upset with the lack of information coming from the regions during the early phases of the public discussion of the draft Constitution, as without such reports it was impossible for central authorities to monitor either the progress of the discussion or popular response. ${ }^{1}$ In response to this dearth of information, Ivan Akulov, the secretary of the Central Executive Committee (TsIK), sent out a directive in August 1936 with specific questions to be answered by the regional officials in their reports on the implementation of the popular discussion.

The questions that Moscow presented to regional officials undoubtedly shaped the information supplied in the reports and how the documents, on which this work is based, portrayed discussion of the draft Constitution. The specified questions resulted in a great deal of information on topics such as criticism of local Soviet leaders, their actions, and enemies infiltrating both the discussion and various institutions. Because the regional and district officials were specifically asked to find this material, it is difficult to ascertain whether these issues were really of great local importance, or if the many examples were simply ways of fulfilling a central directive. In the case of both the criticism of local Soviets and of the enemy infiltration, I suspect they were less important to the people of the Kirov region than their presence in the documentation would imply, due to the repetition of the same six or seven incidents in many documents. This information may not have reflected the reality in the Kirov region, but it indicates the focus and concern of central officials. They wanted the discussion to be instrumental in purging incompetent people from the urban and rural soviets and feared a return of enemy elements, even as they enfranchised them in the draft Constitution.

Additionally, most of the suggestions, additions, and corrections were collected and recorded by local and regional state and Party agencies, which 
were under tremendous pressure to quickly collect additions and corrections and send them to the Central Executive Committee. Regional and local officials were often unable to complete such tasks efficiently or accurately, raising questions about the completeness and accuracy of the collected popular suggestions, which provide the bulk of the source material for Chapters 5 and 6.

The reported number of suggestions gathered and sent to Moscow from the Kirov region varied rather considerably. On November 22, 1936, the head of the Kirov Regional Executive Committee, Aleksandr Alekseevich Bobkov, reported a total of 4,288 suggestions gathered from the krai and sent to Moscow as of October 21. ${ }^{2}$ However, a report to the Central Executive Committee from the Organizational Section of the Kirov Regional Executive Committee dated November 10, 1936 noted that the Regional Executive Committee had received a total of 3,968 additions, corrections, and suggestions to the draft Constitution. ${ }^{3}$ In the material from the district Party committees, district executive committees, city Party committees, Regional Party Committee, and Regional Executive Committee, I read 3,203 suggestions, additions, and corrections to the draft Constitution. It is these 3,203 suggestions from the Party and state archival sources in Kirov that form the basis for the book's analysis. While this material represents the bulk of the additions and corrections gathered by Party and state representatives in the Kirov region, it is incomplete and is dependent on the accuracy with which those tasked with conducting the discussion of the draft Constitution gathered and recorded popular suggestions. Indubitably, many were never recorded or were lost. However, given the large number of suggestions that regional officials and the Central Committee deemed "incorrect," I would suggest that the Kirov region's popular suggestions accurately reflect the concerns of the people and were not consciously edited to fit the prevailing political narrative.

Inaccurate information about the discussion of the draft Constitution, however, poses a problem not just for historians delving into the past but also presented difficulty for the central state leadership who needed to mobilize its people to face a myriad of problems at home and abroad.

In the fall of 1936, the Central Committee expressed alarm about the completeness and accuracy of materials from the Kirov region. On November 13, 1936, the Deputy Secretary of the Central Executive Committee, N. Novikov, sent a letter to the head of the Kirov Regional Executive Committee, Bobkov, accusing the Regional Executive Committee of mishandling suggestions and falsifying their reports to the Central Executive Committee. He stated:

it is obvious that the compiling of additions and corrections to the draft Constitution in the Organizational Section of the Regional Executive Committee did not proceed without some problems as the statistical reports are very confusing and they had been made very tentatively as 
the Regional Executive Committee doesn't know the exact number of additions. ${ }^{4}$

He believed that the Regional Executive Committee had tried to cover up their disorganization by lying. Novikov bluntly accused the Regional Executive Committee of using fictitious statistics (1,543 and 2,142 additions respectively) in place of the 219 suggestions on October 2 and 660 on October 10 that had been actually accounted for. ${ }^{5}$ He warned Bobkov that, "all of that whitewashing and cheating made your own situation awkward because of the deliberately false data given for your article in Pravda." 6 Novikov demanded that Bobkov pay attention to the organization of the statistical report on suggestions and additions to the draft Constitution and also report what action he had taken to correct the problem. ${ }^{7}$

On November 22, Bobkov responded to Novikov's accusations. Bobkov blamed local officials for the late compilation of some of the additions and suggestions, noting that, "there are around 900 suggestions that we have not yet sent because they were received late and because a portion of them aren't relevant to the draft Constitution, but relate to the work of local organs of power." ${ }^{8} \mathrm{He}$ also detailed the process by which the additions and corrections from the Kirov region had been gathered into books and when they had been specifically sent to Moscow, "refut[ing] the fiction, which [Central Executive Committee] instructor Maslov reported to you, falsifying the true state of affairs." 9

This heated exchange between two bureaucrats highlights several important aspects of the discussion of the draft Constitution. The incredibly negative reaction from the Central Executive Committee to what it viewed as incompetence and fraud demonstrated that the highest authorities in the Soviet Union cared about the popular suggestions and the feedback that its citizens offered. Novikov's sharp rebuke to Bobkov, as well as Mikhail Kalinin and Ivan Akulov's concern about poor responses from the regions and subsequent mandated reporting, highlight the seriousness with which the central authorities viewed this campaign in particular and the responsiveness of regional and local officials in general. ${ }^{10}$ Bobkov defended his people against the attack from the central authorities while simultaneously passing blame for late or incomplete reports onto local officials. This sort of blame-mongering was common in 1930s Soviet bureaucratic relations and was, at least in part, a function of the extreme pressures of the Stalinist period. ${ }^{11}$ The obvious friction between the Central Executive Committee's representative, Inspector Maslov, and the Regional Executive Committee's representative, Bobkov, also emphasized the conflicting goals and duties that splintered Soviet bureaucracy. The material covered in this book reveals the limits of Party and state power in that the state offices, be it at the national, regional, or local level, and corresponding Party organizations, could not always control or direct the discussion as they wished. 


\section{Notes}

1 GARF, f. 3316, op. 8, d. 222, 1. 36.

2 GAKO, f. R-2168, op. 1, d. 473, 1. 123.

3 GARF, f. R-3316, op. 41, d. 113, 1. 1; GAKO, f. R-2168, op. 1, d. 473, 11. $122-123$.

4 GAKO, f. R-2168, op. 1, d. 473, 1. 122.

5 GAKO, f. R-2168, op. 1, d. 473, 1. 122.

6 GAKO, f. R- 2168, op. 1, d. 473, 1. 122.

7 GAKO, f. R-2168, op. 1, d. 473, 1. 122.

8 GAKO, f. R-2168, op. 1, d. 473, l. 123.

9 GAKO, f. R-2168, op. 1, d. 473, 1. 123.

$10 \mathrm{~J}$. Arch Getty and Oleg Naumov deal with the issue of regional and local compliance and non-compliance with central state and Party demands in detail in The Road to Terror: Stalin and the Self-Destruction of the Bolsheviks, 19321939 (New Haven: Yale University Press, 1999).

11 Larry Holmes deals with this culture of negativity in depth in Grand Theater: Regional Governance in Stalin's Russia, 1931-1941 (Lanham, MD: Lexington Books, 2009). 


\section{The draft Constitution of the USSR (As published in Pravda, June 12, 1936. This is the author's translation.)}

\section{Chapter I}

\section{Social construction}

Article 1. The Union of Soviet Socialist Republics is a socialist state of workers and peasants.

Article 2. The Soviets of Laboring People's Deputies, which grew and attained strength as a result of the overthrow of the landlords and capitalists and the achievement of the dictatorship of the proletariat, constitute the political foundation of the USSR.

Article 3. In the USSR, all power belongs to the laboring people of the town and country as represented by the Soviets of Laboring People's Deputies.

Article 4. The socialist system of economy and the socialist ownership of the means and instruments of production, firmly established as a result of the abolition of the capitalist system of economy, the abolition of private ownership of the means and instruments of production, and the abolition of the exploitation of man by man, constitutes the economic foundation of the USSR.

Article 5. Socialist property in the USSR exists either in the form of state property (the possession of the whole people) or in the form of cooperative and collective-farm property (property of a collective farm or property of a cooperative association).

Article 6. The land, its natural deposits, waters, forests, mills, factories, mines, rail, water and air transport, banks, means of communication, large state-organized agricultural enterprises (state farms, machine and tractor stations, etc.), as well as municipal enterprises and primary housing stock in the cities and industrial centers, are state property; that is, they belong to the whole people.

Article 7. Social enterprises in collective farm and cooperative organizations with their living and inanimate stock, used in collective farm and 
cooperative organization production equally with their communal buildings, are property of the collective farms and cooperative organizations. Every collective farm household can have a small garden plot and personal property for subsidiary economic activity on the garden plot, productive livestock, fowl, and petty agricultural stock as specified in agreement with the charter of the artel'.

Article 8 . The land occupied by collective farms is secured to them for an unlimited time, that is, in perpetuity.

Article 9. Alongside the socialist system of economy, which is the predominant form of economy in the USSR, the law permits the small private economy of individual smallholders and artisans based on their personal labor and precluding the exploitation of the labor of others.

Article 10. The right of citizens to personal ownership of their incomes from work and of their savings, of their dwelling houses and subsidiary household economy, their household furniture and utensils and articles of personal use and convenience, as well as the right of inheritance of personal property of citizens, is protected by law.

Article 11. The economic life of the USSR is determined and directed by the state national economic plan in the interest of increasing the public wealth, of steadily improving the material and cultural level of the laborers, of consolidating the independence of the USSR, and strengthening its defensive capacity.

Article 12. Labor is considered the duty of every able citizen on the principle: "he who does not work does not eat." In the USSR, the principle of socialism-"From each to his ability, to each according to his needs"is implemented.

\section{Chapter II}

\section{State construction}

Article 13. The Union of Soviet Socialist Republics is a unified state, formed on the basis of the voluntary association of Soviet Socialist Republics having equal rights, namely:

The Russian Soviet Federated Socialist Republic;

The Ukrainian Soviet Socialist Republic;

The Byelorussian Soviet Socialist Republic;

The Azeri Soviet Socialist Republic;

The Georgian Soviet Socialist Republic;

The Armenian Soviet Socialist Republic;

The Turkmen Soviet Socialist Republic;

The Uzbek Soviet Socialist Republic; 
The Tadjik Soviet Socialist Republic;

The Kazakh Soviet Socialist Republic;

The Kirghiz Soviet Socialist Republic.

Article 14. The jurisdiction of the Union of Soviet Socialist Republics, as represented by its highest organs of state authority and organs of government, covers:

a Representation of the Union in international relations, conclusion and ratification of treaties with other states;

b Questions of war and peace;

c Admission of new republics into the USSR;

d Control over the observance of the Constitution of the USSR and ensuring conformity of the Constitutions of the Union Republics with the Constitution of the USSR;

e Approving the alterations of boundaries between Union Republics;

$\mathrm{f}$ Organization of the defense of the USSR and the leadership of all armed forces of the USSR;

g Foreign trade on the basis of state monopoly;

$\mathrm{h}$ Safeguarding the State security;

i Establishment of the national economic plans of the USSR;

j Approval of the single-state budget of the USSR, as well as of the taxes and revenues dealing with the educational all-Union, Republican, and local budgets;

$\mathrm{k}$ Administration of banks, industrial and agricultural establishments and enterprises, and trading enterprises of all-Union importance;

1 Administration of transport and communications;

$m$ Leadership of monetary and credit systems;

n Organization of state insurance;

o Raising and granting of loans;

p Establishment of the basic principles for the use of land as well as for the use of natural deposits, forests, and waters;

q Establishment of the basic principles in the areas of education and public health;

$r$ Organization of a uniform system of national economic statistics;

$s$ Establishment of the principles of labor legislation;

$t$ Legislation on the judicial system and judicial procedure; criminal and civil codes;

$\mathrm{u}$ Laws on union citizenship; laws on the rights of foreigners;

$\mathrm{v}$ Issuing of all-Union acts of amnesty.

Article 15. The sovereignty of the Union Republics is limited only within the provisions set forth in Article 14 of the Constitution of the USSR. Outside of these provisions, each Union Republic exercises state authority independently. The USSR protects the sovereign rights of the Union Republics. 
Article 16. Each Union Republic has its own Constitution, which takes account of the specific features of the Republic and is formulated in complete conformity with the Constitution of the USSR.

Article 17. The right freely to secede from the USSR is reserved for every Union Republic.

Article 18. The territory of a Union Republic may not be altered without its consent.

Article 19. The laws of the USSR have equal strength within the territory of every Union Republic.

Article 20. In the event of divergence between a law of a Union Republic and an all-Union law, the all-Union law prevails.

Article 21. For citizens of the USSR, a single Union citizenship is established. Every citizen of a Union Republic is considered a citizen of the USSR.

Article 22. The Russian Soviet Federated Socialist Republic consists of these regions (krai): Azovo-Black Sea region, the Far Eastern region, Western Siberian region, Kransoiarsk, Northern Caucasian region; (oblast'): Voronezh region, Eastern Siberian region, Gorky region, Western region, Ivanov region, Kalinin region, Kirov region, Kuibashev region, Kursk region, Leningrad region, Moscow region, Omsk region, Orenburg region, Saratov region, Sverdlovsk region, Northern region, Stalingrad region, Chliabinsk region, Yaroslavl region; Autonomous Soviet Socialist Republics: Tartar republic, Bashkir republic, Dagestan, Buriat-Mongol republic, KabardinoBalkar republic, Kalmytsk republic, Karelia republic, Komi republic, Crimean republic, Marii republic, Mordovsk republic, Volga German republic, Northern Ossetia, Udmurt republic, Chechno-Ingushetia, Chuvash republic, Iakutia; Autonomous regions: Adygeisk region, Jewish region, Karachevsk region, Oirotsk region, Khakassk region, Cherkessk region.

Article 23. The Ukrainian Soviet Socialist Republic consists of the Vinnitsa, Dnepropetrovsk, Donetsk, Kiev, Odessa Kharkov, Chenigov regions, and Moldovsk Autonomous Socialist Soviet Republic.

Article 24. The Azeri Soviet Socialist Republic includes the Nakhichevan Autonomous Soviet Socialist Republic and the Nagorno-Karabakh Autonomous Region.

Article 25. The Georgian Soviet Socialist Republic includes the Abkhazian Autonomous Soviet Socialist Republic, the Adjar Autonomous Soviet Socialist Republic, and the South Ossetian Autonomous Region.

Article 26. The Uzbek Soviet Socialist Republic includes the Kara-Kalpak Autonomous Soviet Socialist Republic.

Article 27. The Tadjik Soviet Socialist Republic includes the GornoBadakhshan Autonomous Region. 
Article 28. The Kazakh Soviet Socialist Republic consists of the Aktyubinsk, Alma-Ata, East Kazakhstan, West Kazakhstan, Karaganda, and South Kazakhstan Regions.

Article 29. The Armenian Soviet Socialist Republic, Belorussian SSR, Turkmen SSR, and Kirgiz SSR don't have any autonomous regions within their borders.

\section{Chapter III}

\section{The highest organs of state power of the USSR}

Article 30. The highest organ of state authority of the USSR is the Supreme Soviet of the USSR.

Article 31. The Supreme Soviet of the USSR exercises all rights conferred on the Union of Soviet Socialist Republics in accordance with Article 14 of the Constitution, insofar as they do not, by virtue of the Constitution, come within the jurisdiction of organs of the USSR that are accountable to the Supreme Soviet of the USSR, that is, the Presidium of the Supreme Soviet of the USSR, the Council of People's Commissars of the USSR, and the People's Commissariats of the USSR.

Article 32. The legislative power of the USSR is exercised exclusively by the Supreme Soviet of the USSR.

Article 33. The Supreme Soviet of the USSR consists of two Chambers: the Soviet of the Union and the Soviet of Nationalities.

Article 34. The Soviet of the Union is elected by the citizens of the USSR on the basis of one deputy for every 300,000 people.

Article 35. The Soviet of Nationalities is elected by the citizens of the USSR, allocated by Union and Autonomous Republics and Soviets of Laborers Deputies of Autonomous Regions on the basis of ten deputies from each Union Republic, five deputies from each Autonomous Republic, and two deputies from each Autonomous Region.

Article 36. The Supreme Soviet of the USSR is elected for a term of four years.

Article 37. Both Chambers of the Supreme Soviet of the USSR, the Soviet of the Union, and the Soviet of Nationalities have equal rights.

Article 38. The Soviet of the Union and the Soviet of Nationalities can in equal measure initiate legislation.

Article 39. A law is considered adopted if passed by both Chambers of the Supreme Soviet of the USSR by a simple majority vote in each.

Article 40. Laws, passed by the Supreme Soviet of the USSR, are published with the signatures of the Chairman and Secretary of the Presidium of the Supreme Soviet of the USSR. 
Article 41. Sessions of the Soviet of the Union and the Soviet of Nationalities begin and end at the same time.

Article 42. The Soviet of the Union elects a Chairman of the Soviet of the Union and two Vice-Chairmen.

Article 43. The Soviet of Nationalities elects a Chairman of the Soviet of Nationalities and two Vice-Chairmen.

Article 44. The Chairmen of the Soviet of the Union and the Soviet of Nationalities preside over the sittings of the respective Chambers and direct the internal proceedings of these bodies.

Article 45. Joint meetings of both Chambers of the Supreme Soviet of the USSR are presided over alternately by the Chairman of the Soviet of the Union and the Chairman of the Soviet of Nationalities.

Article 46. Sessions of the Supreme Soviet of the USSR are convened by the Presidium of the Supreme Soviet of the USSR twice a year. Special sessions are convened by the Presidium of the Supreme Soviet of the USSR at its discretion or at the request of one of the Union Republics.

Article 47. In case of disagreement between the Soviet of the Union and the Soviet of Nationalities, the question is referred for settlement to a conciliatory commission formed on an equal basis. If the conciliation commission fails to arrive at an agreement, or if its decision fails to satisfy one of the Chambers, the question is considered for a second time by the Chambers. Failing agreement between the two Chambers, the Presidium of the Supreme Soviet of the USSR dissolves the Supreme Soviet of the USSR and orders new elections.

Article 48. The Supreme Soviet of the USSR elects the Presidium of the Supreme Soviet of the USSR at a joint sitting of both Chambers consisting of a Chairman of the Presidium of the Supreme Soviet of the USSR, 4 ViceChairmen, a Secretary of the Presidium, and 31 members of the Presidium. The Presidium of the Supreme Soviet of the USSR is accountable to the Supreme Soviet of the USSR for all its activities.

Article 49. The Presidium of the Supreme Soviet of the USSR:

a Convenes the sessions of the Supreme Soviet of the USSR;

b Interprets laws of the USSR currently in force, issues decrees;

c Dissolves the Supreme Soviet of the USSR in conformity with Article 47 of the Constitution of the USSR and orders new elections;

d Conducts nationwide referendums on its own initiative or on the request of one of the Union Republics;

e Rescinds the decisions and orders of the Council of People's Commissars of the USSR and of the Councils of People's Commissars of the Union Republics in case they do not conform to law; 


\section{Appendix}

$\mathrm{f}$ Between sessions of the Supreme Soviet of the USSR, relieves of their posts and appoints individual People's Commissars of the USSR on the recommendation of the Chairman of the Council of People's Commissars of the USSR, subject to subsequent confirmation by the Supreme Soviet of the USSR;

g Awards decorations and confers titles of honor of the USSR;

$h$ Exercises the right of pardon;

i Appoints and removes the higher commands of the armed forces of the USSR;

j In the intervals between sessions of the Supreme Soviet of the USSR, proclaims a state of war in the event of armed attack on the USSR;

$\mathrm{k}$ Orders general or partial mobilization;

1 Ratifies international treaties;

$\mathrm{m}$ Appoints and recalls plenipotentiary representatives of the USSR to foreign states;

$\mathrm{n}$ Accepts accredited diplomatic representatives from foreign states.

Article 50. The Soviet of the Union and the Soviet of Nationalities elect Credentials Commissions that verify the credentials of the members of each Chamber. On the recommendation of the Credentials Commissions, the Chambers decide either to endorse the credentials or to annul the election of the individual deputies.

Article 51. The Supreme Soviet of the USSR, when it deems it necessary, appoints auditing commissions on any matter. It is the duty of all institutions and public servants to comply with the demands of these commissions and to submit to them the necessary materials and documents.

Article 52. A deputy of the Supreme Soviet of the USSR may not be prosecuted or arrested without the consent of the Supreme Soviet of the USSR, and during the period when the Supreme Soviet of the USSR is not in session, without the consent of the Presidium of the Supreme Soviet of the USSR.

Article 53. At the end of the term of office or after the dissolution of the Supreme Soviet of the USSR prior to the expiration of its term of office, the Presidium of the Supreme Soviet of the USSR retains its powers until the formation of a new Presidium of the Supreme Soviet of the USSR by the newly-elected Supreme Soviet of the USSR.

Article 54. At the end of the term of office of the Supreme Soviet of the USSR, or in case of its dissolution prior to the expiration of its term of office, the Presidium of the Supreme Soviet of the USSR orders new elections to be held within a period not exceeding two months from the date of expiration of the term of office or dissolution of the Supreme Soviet of the USSR.

Article 55. The newly-elected Supreme Soviet of the USSR is convened by the outgoing Presidium of the Supreme Soviet of the USSR not later than one month after the elections. 
Article 56. The Supreme Soviet of the USSR, at a joint sitting of both Chambers, appoints the Government of the USSR—the Council of People's Commissars of the USSR.

\section{Chapter IV}

\section{The highest organs of state authority of the Union Republics}

Article 57. The highest organ of state power of a Union Republic is the Supreme Soviet of the Union Republic.

Article 58. The Supreme Soviet of a Union Republic is elected by the citizens of the Republic for a term of four years. The basis of representation is established by the Constitution of the Union Republic.

Article 59. The Supreme Soviet of a Union Republic is the only legislative organ of the Republic.

Article 60. The Supreme Soviet of a Union Republic:

a Adopts the Constitution of the Republic and amends it in accordance with Article 16 of the Constitution of the USSR;

b Confirms the Constitutions of the Autonomous Republics forming part of it and defines the boundaries of their territories;

c Approves the national economic plan and also the Republic's budget;

d Exercises the right of amnesty and pardon of citizens sentenced by the judicial organs of the Union Republic.

Article 61. The Supreme Soviet of a Union Republic elects the Presidium of the Supreme Soviet of the Union Republic, consisting of a Chairman of the Presidium of the Supreme Soviet of the Union Republic, his deputy, and members of the Presidium of the Supreme Soviet of the Union Republic. The powers of the Presidium of the Supreme Soviet of a Union Republic are defined by the Constitution of the Union Republic.

Article 62. The Supreme Soviet of a Union Republic elects a Chairman and Vice-Chairmen to conduct its meetings.

Article 63. The Supreme Soviet of a Union Republic appoints the Government of the Union Republic, namely, the Council of People's Commissars of the Union Republic.

\section{Chapter V}

\section{The organs of state administration of the USSR}

Article 64. The highest executive and administrative organ of state power of the Union of Soviet Socialist Republics is the Council of People's Commissars of the USSR. 


\section{Appendix}

Article 65. The Council of People's Commissars of the USSR is responsible to the Supreme Soviet of the USSR and accountable to it.

Article 66. The Council of People's Commissars of the USSR issues decisions and orders on the basis and in pursuance of the laws in operation and supervises their execution.

Article 67. The decisions and orders of the Council of People's Commissars of the USSR are binding throughout the territory of the USSR.

Article 68. The Council of People's Commissars of the USSR:

a Coordinates and directs the work of the All-Union and UnionRepublican People's Commissariats of the USSR and of other institutions, economic and cultural, under its administration;

b Adopts measures to carry out the national economic plan and the state budget, and to strengthen the credit and monetary system;

c Adopts measures for the maintenance of public order, for the protection of the interests of the state, and for the safeguarding of the rights of citizens;

d Exercises general guidance in respect to relations with foreign states;

e Fixes the annual contingent of citizens to be called up for military service and directs the general organization and development of the armed forces of the country.

Article 69. The Council of People's Commissars of the USSR has the right, in respect of those branches of administration and economy which come within the jurisdiction of the USSR, to suspend decisions and orders of the Councils of People's Commissars of the Union Republics and to annul orders and instructions of People's Commissars of the USSR.

Article 70. The Council of People's Commissars of the USSR is appointed by the Supreme Soviet of the USSR and consists of:

The Chairman of the Council of People's Commissars of the USSR;

The Vice-Chairmen of the Council of People's Commissars of the USSR;

The Chairman of the State Planning Commission of the USSR;

The Chairman of the State Control Commission;

The People's Commissars of the USSR;

The Chairman of the Procurement Commission;

The Chairman of the Committee on Arts;

The Chairman of the Committee on Higher Education.

Article 71. The Government of the USSR, or a People's Commissar of the USSR to whom a question of a member of the Supreme Soviet of the USSR 
is addressed, must give a verbal or written reply to the respective Chamber within a period of not more than three days.

Article 72. The People's Commissars of the USSR direct the branches of state administration which come within the jurisdiction of the USSR.

Article 73. The People's Commissars of the USSR issue, within the limits of the jurisdiction of the respective People's Commissariats, orders and instructs on the basis and in accordance with the laws in operation, and also of decisions and orders of the Council of People's Commissars of the USSR, and supervise their execution.

Article 74. The People's Commissariats of the USSR are either All-Union or Union-Republican Commissariats.

Article 75. The All-Union People's Commissariats direct the branches of state administration entrusted to them throughout the territory of the USSR either directly or through bodies appointed by them.

Article 76. The Union-Republican People's Commissariats direct the branches of state administration entrusted to them through the corresponding People's Commissariats of the Union Republics.

Article 77. The following People's Commissariats are All-Union People's Commissariats:

Defense,

Foreign Affairs,

Foreign Trade,

Means of communication (putei coobshcheniia),

Communications (sviazi),

Water Transport,

Heavy Industry.

Article 78. The following People's Commissariats are Union-Republican People's Commissariats:

Food Industry,

Light Industry,

Forest Industry,

Agriculture,

State Grain and Livestock Farms,

Finance,

Internal Trade,

Internal Affairs,

Justice,

Public Health. 


\section{Appendix}

\section{Chapter VI}

\section{The organs of administration of the Union Republics}

Article 79. The highest executive and administrative organ of state authority of a Union Republic is the Council of People's Commissars of the Union Republic.

Article 80. The Council of People's Commissars of a Union Republic is responsible to the Supreme Soviet of the Union Republic and accountable to it.

Article 81. The Council of People's Commissars of a Union Republic issues decisions and orders on the basis and in accordance with the laws in operation of the USSR and of the Union Republic, and of the decisions and orders of the Council of People's Commissars of the USSR, and supervises their execution.

Article 82. The Council of People's Commissars of a Union Republic has the right to suspend decisions and orders of Councils of People's Commissars of Autonomous Republics, and to annul decisions and orders of Executive Committees of Soviets of Laborers' Deputies of Regions and Autonomous Regions.

Article 83. The Council of People's Commissars of a Union Republic is appointed by the Supreme Soviet of the Union Republic and consists of:

The Chairman of the Council of People's Commissars of the Union Republic;

The Deputy Chairmen;

The Chairman of the State Planning Commission;

The People's Commissars of:

The Food Industry,

Light Industry,

Forest Industry,

Agriculture,

State Grain and Livestock Farms,

Finance,

Internal Trade,

Internal Affairs,

Justice,

Public Health,

Education,

Local Industry,

Communal Economy, and Social Maintenance;

The Representative of the Provision Committee; 
The Head of the Art Administration;

Representatives of All-Union People's Commissariat.

Article 84. The People's Commissars of a Union Republic direct the branches of state administration which come under the jurisdiction of the Union Republic.

Article 85. The People's Commissars of a Union Republic issue, within the limits of the jurisdiction of their respective People's Commissariats, orders and instructions on the basis and in accordance with the laws of the USSR and of the Union Republic, of the decisions and orders of the Council of People's Commissars of the USSR and that of the Union Republic, and of the orders and instructions of the Union Republican People's Commissariats of the USSR.

Article 86. The People's Commissariats of a Union Republic are either Union-Republican or Republican Commissariats.

Article 87. The Union-Republican People's Commissariats direct the branches of state administration entrusted to them and are subordinate both to the Council of People's Commissars of the Union Republic and to the corresponding Union-Republican People's Commissariats of the USSR.

Article 88. The Republican People's Commissariats direct the branches of state administration entrusted to them and are directly subordinate to the Council of People's Commissars of the Union Republic.

\section{Chapter VII}

\section{The highest organs of state power of Autonomous Soviet Socialist Republics}

Article 89. The highest organ of state authority of an Autonomous Republic is the Supreme Soviet of the ASSR.

Article 90. The Supreme Soviet of an Autonomous Republic is elected by the citizens of the Republic for a term of four years on the basis of representation established by the Constitution of the Autonomous Republic.

Article 91. The Supreme Soviet of an Autonomous Republic is the sole legislative organ of the ASSR.

Article 92. Each Autonomous Republic has its own Constitution, which takes account of the specific features of the Autonomous Republic and is drawn up in complete accordance with the Constitution of the Union Republic.

Article 93. The Supreme Soviet of an Autonomous Republic elects the Presidium of the Supreme Soviet of the Autonomous Republic and appoints the Council of People's Commissars of the Autonomous Republic, in accordance with its Constitution. 


\section{Chapter VIII}

\section{The local organs of state power}

Article 94. The organs of state authority in territories, regions, autonomous regions, areas, districts, cities, and rural localities (stations, villages, hamlets, kishlaks, auls) are the Soviets of Laborers' Deputies.

Article 95. The Soviets of Laborers' Deputies of territories, regions, autonomous regions, areas, districts, cities, and rural localities (stations, villages, hamlets, kishlaks, auls) are elected by the laborers of the respective territories, regions, autonomous regions, areas, districts, cities, or villages for a term of two years.

Article 96. The basis of representation for Soviets of Laborers' Deputies is defined by the Constitutions of the Union Republics.

Article 97. The Soviets of Laborers' Deputies direct the work of the organs of administration subordinate to them; maintain public order, the observance of the laws, and the protection of the rights of citizens; direct local economic and cultural organization and development; and draw up the local budgets.

Article 98. The Soviets of Laborers' Deputies adopt decisions and issue orders within the limits of the powers vested in them by the laws of the USSR and of the Union Republic.

Article 99. The executive and administrative organs of the Soviets of Laborers' Deputies of territories, regions, autonomous regions, areas, districts, cities, and rural localities are the Executive Committees elected by them, consisting of a Chairman, his deputy, and members.

Article 100. The executive and administrative organ of rural Soviets of Laborers' Deputies in small settlements, in accordance with the Constitutions of the Union Republics, is the Chairman and his deputy elected by them.

Article 101. The executive organs of the Soviets of Laborers' Deputies are directly accountable both to the Soviets of Laborers' Deputies that elected them and to the executive organ of the superior Soviet of Laborers' Deputies.

\section{Chapter IX}

\section{The courts and the procuracy}

Article 102. In the USSR, justice is administered by the Supreme Court of the USSR, the Supreme Courts of the Union Republics, the Territorial and the Regional courts, the courts of the Autonomous Republics and the Autonomous Regions, the special courts of the USSR established by decision of the Supreme Soviet of the USSR, and the People's Courts. 
Article 103. All court cases are tried with the participation of people's assessors, except in cases specially provided for by law.

Article 104. The Supreme Court of the USSR is the highest judicial organ. The Supreme Court of the USSR is charged with the supervision of the judicial activities of all the judicial organs of the USSR and of the Union Republics.

Article 105. The Supreme Court of the USSR and the special courts of the USSR are elected by the Supreme Soviet of the USSR for a term of five years.

Article 106. The Supreme Courts of the Union Republics are elected by the Supreme Soviets of the Union Republics for a term of five years.

Article 107. The Supreme Courts of the Autonomous Republics are elected by the Supreme Soviets of the Autonomous Republics for a term of five years.

Article 108. The Territorial and the Regional courts and the courts of the Autonomous Regions are elected by the Territorial and Regional Soviets of Laborers' Deputies or by the Soviets of Laborers' Deputies of the Autonomous Regions for a term of five years.

Article 109. People's Courts are elected by the citizens of the district on the basis of universal, direct, and equal suffrage by secret ballot for a term of three years.

Article 110. Judicial proceedings are conducted in the language of the Union Republic, Autonomous Republic, or Autonomous Region, with persons not knowing this language being guaranteed every opportunity of fully acquainting themselves with the material of the case through an interpreter and likewise the right to use their own language in court.

Article 111. In all courts of the USSR, cases are heard in public, unless otherwise provided for by law, and the accused is guaranteed the right to defense.

Article 112. Judges are independent and subject only to the law.

Article 113. Supreme supervision over the strict execution of the laws by all People's Commissariats and institutions subordinated to them, as well as by public servants and citizens of the USSR, is vested in the Procurator of the USSR.

Article 114. The Procurator of the USSR is appointed by the Supreme Soviet of the USSR for a term of seven years.

Article 115. Procurators of Republics, Territories, and Regions, as well as Procurators of Autonomous Republics and Autonomous Regions, are appointed by the Procurator of the USSR for a term of five years.

Article 116. District procurators are appointed for a term of five years by the Procurators of the Union Republics, subject to the approval of the Procurator of the USSR. 
Article 117. The organs of the Procurator's Office perform their functions independently of any local organs whatsoever, being subordinate solely to the Procurator of the USSR.

\section{Chapter X}

\section{The fundamental rights and duties of citizens}

Article 118. Citizens of the USSR have the right to work, that is, are guaranteed the right to employment and payment for their work in accordance with its quantity and quality. The right to work is ensured by the socialist organization of the national economy, the steady growth of the productive forces of Soviet society, the elimination of the possibility of economic crises, and the abolition of unemployment.

Article 119. Citizens of the USSR have the right to rest. The right to rest is ensured by the reduction of the working day to seven hours for the overwhelming majority of the workers, the institution of annual vacations with full pay for workers and service workers, and the provision of a wide network of sanatoria, rest homes, and clubs for the accommodation of the laborers.

Article 120. Citizens of the USSR have the right to material security in old age and also in case of sickness or loss of capacity to work. This right is ensured by the extensive development of social insurance of workers and service workers at state expense, free medical service, and the provision of a wide network of health resorts for the use of the laborers.

Article 121. Citizens of the USSR have the equal right to education. This right is guaranteed by the existence of universal compulsory elementary education, free education up to higher school, a system of state stipends for the overwhelming majority of students in higher education, and state aid for instruction in schools in native languages, the organization in factories, state farms, machine tractor stations, and on collective farms of industrialtechnical and agricultural instruction for laborers.

Article 122. Women in the USSR are granted equal rights with men in all areas of economic, state, cultural, social, and political life. The ability to use these rights is guaranteed to women by granting them an equal right with men to work, payment for work, rest, social insurance, and education, and by state protection of the interests of mother and child, maternity leave with full pay, and the provision of a wide network of maternity homes, nurseries, and kindergartens.

Article 123. Equal rights of citizens of the USSR, irrespective of their nationality or race, in all areas of economic, state, cultural, social, and political life, is an inviolable law. Any direct or indirect restriction of the rights of, or, conversely, any establishment of direct or indirect privileges for, citizens on account of their race or nationality, as well as any advocacy 
of racial or national exclusiveness or hatred and contempt, is punishable by law.

Article 124. In order to ensure to citizens freedom of conscience, the church in the USSR is separated from the state, and the school from the church. Freedom from religious cults and freedom from antireligious propaganda is recognized for all citizens.

Article 125. In conformity with the interests of the working people, and in order to strengthen the socialist system, the citizens of the USSR are guaranteed by law:
a freedom of speech;
b freedom of the press;
c freedom of assembly and meetings;
d freedom of street processions and demonstrations.

These civil rights are ensured by placing at the disposal of the laborers and their organizations printing presses, stocks of paper, public buildings, the streets, communications facilities, and other material requisites for the exercise of these rights.

Article 126. In accordance with the interests of the laborers, and in order to develop the organizational initiative and political activity of the masses of the people, citizens of the USSR are ensured the right to unite in public organizations - trade unions, cooperative associations, youth organizations, sport and defense organizations, cultural, technical, and scientific societies; and the most active and politically most-conscious citizens in the ranks of the working class and other sections of the laborers unite in the Communist Party of the Soviet Union, which is the vanguard of laborers in their struggle to strengthen and develop the socialist system and is the leading core of all organizations of the laborers, both public and state.

Article 127. Citizens of the USSR are guaranteed the inviolability of their person. No one may be placed under arrest with the exception of a court order or with the sanction of the procurator.

Article 128. The inviolability of the homes of citizens and privacy of correspondence are protected by law.

Article 129. The USSR grants the right of asylum to foreign citizens persecuted for defending the interests of the laborers, or for their scientific activities, or for their struggle for national liberation.

Article 130. It is the duty of every citizen of the USSR to observe the Constitution of the Union of Soviet Socialist Republics, to observe the laws, to maintain labor discipline, honestly to perform public duties, and to respect the rules of socialist conduct. 


\section{Appendix}

Article 131. Every citizen of the USSR is obligated to take care of and strengthen social socialist property, as the sacred and inviolable foundation of soviet construction, as the source of wealth and power of the motherland, and as the source of a prosperous and cultural life for all laborers. People, encroaching on social socialist property, are considered enemies of the people.

Article 132. Universal military service is law. Military service in the Workers' and Peasants' Red Army is an honorable duty of the citizens of the USSR.

Article 133. The defense of the fatherland is the sacred duty of every citizen of the USSR. Treason to the motherland-violation of the oath of allegiance, desertion to the enemy, impairing the military power of the state, and espionage for a foreign state are punishable with all the severity of the law as the most heinous of crimes.

\section{Chapter XI}

\section{The electoral system}

Article 134. The election of deputies to all Soviets of Laborers' Deputiesof the Supreme Soviet of the USSR, the Supreme Soviets of the Union Republics, the Soviets of Laborers' Deputies of the Territories and Regions, the Supreme Soviets of the Autonomous Republics, Soviets of Laborers' Deputies of Autonomous Regions, and area, district, city, and rural (station, village, hamlet, kishlak, aul) Soviets of Laborers' Deputiesare conducted on the basis of universal, direct, and equal suffrage by secret ballot.

Article 135. Elections of deputies are universal: all citizens of the USSR who have reached the age of 18 have the right to participate in the election of deputies and to be elected, with the exclusion of insane people and those deprived of voting rights by the court.

Article 136. Elections of deputies are equal: each citizen has the right to vote and be elected irrespective of race or nationality, religion, educational and residential qualifications, social origin, property status, or past activities.

Article 137. Women have the right to vote and be elected on equal terms with men.

Article 138. Citizens serving in the Red Army have the right to vote and be elected on equal terms with all other citizens.

Article 139. Elections of deputies are direct: all Soviets of Laborers' Deputies, from rural and city Soviets of Laborers' Deputies to the Supreme Soviet of the USSR, are elected by the citizens by direct vote.

Article 140. Voting at elections of deputies is secret. 
Article 141. Candidates for election are nominated according to electoral areas. The right to nominate candidates is secured to public organizations and societies of the working people: Communist Party organizations, trade unions, cooperatives, youth organizations, and cultural societies.

Article 142. It is the duty of every deputy to report to the voters on his work and on the work of the Soviet of Laborers' Deputies, and they may be recalled at any time in the manner established by law upon the decision of a majority of the electors.

\section{Chapter XII}

\section{The coat of arms, flag, and capitol}

Article 143. The coat of arms of the USSR consists of a sickle and hammer against a globe, surrounded by ears of grain, depicted in the rays of the sun, and with the inscription: "Workers of All Countries, Unite!" in the languages of the Union Republics. At the top of the arms is a five-pointed star.

Article 144. The state flag of the USSR is of red cloth, with the sickle and hammer depicted in gold in the upper corner near the staff, and above them a five-pointed red star bordered in gold. The ratio of the width to the length is $1: 2$.

Article 145. The capitol of the Union of Soviet Socialist Republics is the City of Moscow.

\section{Chapter XIII}

\section{Procedure for changing the Constitution}

Article 146. Changes to the Constitution can only occur upon the decision of the Supreme Soviet of the USSR, adopted by a two-thirds majority in each house. 


\section{Bibliography}

\section{Archival sources}

\section{GARF (State Archive of the Russian Federation)}

f. R-3316-The Central Executive Committee of the USSR, 1922-1938 op. 40-Affairs of the Constitutional Commission of 1936 op. 8-Affairs of the 8th Extraordinary All Union Congress of Soviets - 1936 op. 41-Materials from the Constitutional Discussion in 1936

\section{GASPI KO (State Archive of Social and Political History of the Kirov Region)}

f. 1255-The Kirov Region (Krai) Party Committee 1934-1936 op. 1, 2

f. 1293-The Kirov City Party Committee 1934-1991 op. 2

f. 1290-The Kirov Region (oblast') Party Committee 1936-1962, 1964-1991 op. 1

f. 988-The Slobodskoi Raion Party Committee 1927-1955 op. 1

f. 6777-letters to Kirovskaia Pravda op. 3

f. 861-Murashinskii Raion Party Committee 1929-1991 op. 1

f. 790-Nolinskii Raion Party Committee 1929-1991 op. 1

f. 1922-Verkhnekamskii Raion Party Committee op. 1

f. 2158-People's Court, Procuracy and Department of Internal Affairs of Falenskii Raion 1932-1955 op. 1

f. 1460-Sovietkii Raion Party Committee op. 1

f. 2198-Verkhoshizhemskii Raion Party Committee 1929-1959, 1966-1991 op. 1

f. 1177-Iaranskii Raion Party Committee 1929-1962 op. 1

f. 1331-Zuevskii Raion Party Committee op. 2

\section{GAKO (State Archive of the Kirov Region)}

f. R-2684-The Procuracy of the Kirov Region (Krai) 1934-1936 op. 1

f. R-2168-The Kirov Region (Krai) Executive Committee 1930-1936 op. 1

\section{Newspapers and journals}

Izvestiia (Newspaper of the Central Executive Committee of the USSR) Bolshevik (Main theoretical journal of the Communist Party of the USSR) 
Kirovskaia Pravda (Newspaper for the Kirov Region)

Kirovets (Newspaper for Kirovskii Raion)

Leninskii Put' (Newspaper for Slobodskoi Raion)

Pravda (Newspaper of the Central Committee of the USSR)

\section{Published primary sources}

Krylenko, Nikolai, Pravda i obiazanosti sovetskogo grazhdanina (Partizdat TsK

VKP(b), Moskva, 1936).

Krylenko, Nikolai, Osnovnye pravda $i$ obiazanosti sovetskogo grazhdanina (Partizdat TsK VKP(b), Moskva, 1937).

Krylenko, Nikolai, Izbiratel'nyi zakon Soiuza SSR (Sotszhkgiz, Moskva, 1937).

Krylenko, Nikolai, Sovety deputatov trudiashchikhsia - politicheskaia osnova SSSR (Isdatelstvo TsK VLKSI Molodaya Gvardia, Moskva, 1937).

Vyshinsky, Andrei, Konsitutsionye printsipy Sovetskogo Gysudarstva (OGIZ Gosudarstvennoe izdatel'stvo politicheskoi literatury, Moskva, 1940).

Vyshinsky, Andrei, The Law of the Soviet State (The Macmillan Company: New York, 1948).

\section{Secondary sources}

Buckley, Mary, Mobilizing Stalin's Peasants: Heroines and Heroes of Stalin's Fields (Ronan and Littlefield Publishers: New York, 2006).

Chase, William, Workers, Society and the Soviet State (Urbana: University of Illinois Press, 1987).

Coe, Stephen, "Struggles for Authority in the NEP Village: the Early Rural Correspondents Movement 23-27," Europe-Asia Studies, Vol. 48, No. 7 (1996), 1151-1171.

Cohen, Stephen, Bukharin and the Bolshevik Revolution: a Political Biography 1888-1938 (New York: Alfred A. Knopf, Inc., 1973).

Davies, Sarah, Popular Opinion in Stalin's Russia: Terror, Propaganda and Dissent 1931-1941 (Cambridge: Cambridge University Press, 1997).

Easter, Gerald M, "Personal Networks and Postrevolutionary State Building: Soviet Russia Reexamined," World Politics, Vol. 48, No. 4 (Jul. 1996), 551-578.

Fields, Daniel, Rebels in the Name of the Tsar (Boston: Houghton Mifflin, 1976).

Fitzpatrick, Sheila, "How the Mice Buried the Cat: Scenes from the Great Purges of 1937 in the Russian Provinces," Russian Review, Vol. 52, No. 3 (Jul. 1993), 299-320.

Fitzpatrick, Sheila, "Signals from Below: Soviet Letters of Denunciation of the 1930s," The Journal of Modern History, Vol. 68, No. 4, Practices of Denunciation in Modern European History (Dec. 1996), 1789-1989.

Fitzpatrick, Sheila, The Commissariat of Enlightenment: Soviet Organization of Education and Arts under Lunacharsky (Cambridge: Cambridge University Press, 1970).

Fitzpatrick, Sheila, "The Bolsheviks' Dilemma: Class, Culture, and Politics in the Early Soviet Years,” Slavic Review, Vol. 47, No. 4 (Winter 1988), 602-609.

Fitzpatrick, Sheila, Stalin's Peasants: Resistance and Survival in the Russian Village after Collectivization (Oxford: Oxford University Press, 1994). 
Fitzpatrick, Sheila, Everyday Stalinism: Ordinary Life in Extraordinary Times: Soviet Russia in the 1930s (New York: Oxford University Press, 1999).

Frank, Stephen, Crime, Culture, Conflict and Justice in Rural Russia 1856-1914 (Berkeley: University of California Press, 1999).

Getty, J. Arch, "State and Society under Stalin: Constitutions and Elections in the 1930s," Slavic Review, Vol. 50, No. 1 (Spring 1991), 18-35.

Getty, J. Arch, "Pre-election Fever: The Origins of the 1937 Mass Operations" in James Harris, ed., Anatomy of Terror: Political Violence under Lenin and Stalin (Oxford: Oxford University Press, 2013).

Getty, J. Arch “'Excesses Are Not Permitted': Mass Terror and Stalinist Governance in the Late 1930s," Russian Review, Vol. 61, No. 1 (Jan. 2002), 113-138.

Getty, J. Arch and Oleg Naumov, The Road to Terror: Stalin and the Self-Destruction of the Bolsheviks, 1932-1939 (New Haven, Conn.: Yale University Press, 1999).

Goldman, Wendy, Women, the State and Revolution: Soviet Family Policy and Social Life, 1917-1936 (New York: Cambridge University Press, 1993).

Hagenloh, Paul, Stalin's Police: Order and Mass Repression in the USSR, 19261941 (Baltimore: Johns Hopkins University Press, 2009).

Hazard, John, Law and Social Change in the USSR (Toronto: Carswell Co., 1953).

Hellbeck, Jochen, Revolution on My Mind: Writing a Diary under Stalin (Cambridge, Mass: Harvard University Press, 2006).

Hicks, Jeremy, "From Conduits to Commanders: Shifting Views of Workers Correspondents, 1924-26," Revolutionary Russia, Vol. 19, No. 2 (Dec. 2006), 131-149.

Hier, Charles, "Party, Peasants and Power in a Russian District: The Winning of Peasant Support for Collectivization in Sychevka Raion 1928-1931," (unpublished dissertation, University of Pittsburgh, 2004).

Hoffmann, David L, Stalinist Values: The Cultural Norms of Soviet Modernity, 1917-1941 (Ithaca, 2003).

Holmes, Larry, Grand Theater: Regional Governance in Stalin's Russia, 1931-1941 (Lanham, MD: Lexington Books, 2009).

Holmes, Larry, The Kremlin and the Schoolhouse: Reforming Education in Soviet Russia, 1917-1931 (Bloomington: Indiana University Press, 1991).

Hughes, James, Stalinism in a Russian Province: a Study of Collectivization and Dekulakization in Siberia (Basingstoke and London: Macmillan Press Ltd in association with the Centre for Russian and East European Studies, University of Birmingham, 1996).

Huskey, Eugene, Russian Lawyers and the Soviet State: The Origins and Development of the Soviet Bar (Princeton: Princeton University Press, 1986).

Johnson, Robert, Peasant and Proletarian: The Working Class of Moscow at the End of the Nineteenth Century (New Brunswick, NJ: Rutgers University Press, 1979).

Khlevniuk, Oleg, "Top Down vs. Bottom-up: Regarding the Potential of Contemporary 'Revisionism," Cahiers du monde russe, Vol. 56/4 (2015), Online since 01 October 2015, Connection on 01 October 2016. URL: http:// monderusse.revues.org/8253.

Kirovskii Kraiv Tsifrakh (Moskva: TsUNKhU GOSPLANA SSSR, 1936).

Kotkin, Stephan, Magnetic Mountain: Stalinism as a Civilization (Berkeley: University of California Press, 1995).

Kuromiya, Hiroaki, Freedom and Terror in the Donbas: A Ukrainian-Russian Borderland, 1870s-1990s (New York : Cambridge University Press, 1998). 
Lenoe, Matthew, "Letter Writing and the State: Reader Correspondence with Newspapers as a Source for Early Soviet History," Cashiers du Monde russe: Russie, Empire russe, Union sovietique, Etats independants, Vol. 40, No. 1-2 (1999), 139-170.

Lomb, Samantha, "Personal and Political: A Microhistory of the 'Red Column' Collective Farm, 1935-36," The Carl Beck Papers, No. 2404 (2016), http:// carlbeckpapers.pitt.edu/ojs/index.php/cbp/issue/view/178.

Malley, Lynn, Culture of the Future: The Proletkult Movement in Revolutionary Russia (Berkeley: University of California Press, 1990).

Manning, Roberta, "The Soviet Economic Crisis of 1936-1940 and the Great Purges" in Stalinist Terror: New Perspectives eds. J. Arch Getty and Roberta T. Manning (Cambridge; New York: Cambridge University Press, 1993), 117-141.

Manning, Roberta, "Government in the Soviet Countryside in the Stalinist 1930s: The Case of Belyi Raion in 1937," The Carl Beck Papers in Russian and East European Studies, No. 301 (University of Pittsburgh, 1984).

Marshall, T. H., Citizenship and Social Class and Other Essays (Cambridge: Cambridge University Press, 1950).

Medushevskii A. N., "Pravo I sotsial'naia mobilizatsiia v totalitarnom obshchestve: Vsenarodnoe obsuzhdenie Konstitutsii SSSR 1936 goda," Obshestvennye nauki i sovremennost', No. 4 (2016), 89-108.

Nikolaevsky, Boris, "Power and the Soviet Elite: The Letter of an Old Bolshevik and Other Essays," Soviet Studies, Vol. 18, No. 1 (Jul. 1966), 105-107.

Rees, E. A., Rabkrin and the Soviet System of State Control: 1920-1930 (University of Birmingham Press: Birmingham, 1982).

Retish, Aaron, Russia's Peasants in Revolution and Civil War: Citizenship, Identity and the Creation of the Soviet State 1914-1922 (New York: Cambridge University Press, 2008).

Rittersporn, Gabor, Stalinist Simplifications and Soviet Complications: Social Tensions and Political Conflicts in the USSR, 1933-1953 (New York: Harwood Academic Publishers, 1991).

Ronin, S. L., Konstitutsiia 1936 (Gosydarstvennoe izdatel'snvo Uridicheskoi Literatury, 1957).

Shearer, David, Policing Stalin's Socialism: Repression and Social Order in the Soviet Union, 1924 -1953 (New Haven: Yale University Press, 2009).

Shershneva, Elena Aleksandrovna, "Sozdanie Konstitutsiia SSSR 1936 goda," (unpublished dissertation. http://www.dissercat.com/content/sozdanie--konstitutsii---sssr---1936---goda accessed 8/20/2013).

Siegelbaum, Lewis, Stakhanovism and the Politics of Productivity in the USSR, 1935-1941 (New York: Cambridge University Press, 1988).

Siegelbaum, Lewis and Andrei Sokolov, Stalinism as a Way of Life: A Narrative in Documents (New Haven: Yale University Press, 2000).

Sokolov, Andrei, "Konstitutsiia 1936 goda i kul'turnoe nasledie stalinskogo sotsializma," Sotsial'naia istoriia: ezhegodnik (Sankt Petersburg: 2008).

Solomon, Peter, Soviet Criminal Justice under Stalin (New York: Cambridge University Press, 1996).

Solomon, Peter, Reforming Justice in Russia, 1864-1996: Power, Culture, and the Limits of Legal Order (Armonk, NY: M.E. Sharpe, 1997).

Smirnova, I. E., "Otrazhenie 'kulatskoi operatsii' v dokumentakh partiinykh organov Donetskoi Oblasti,” Stalinism v Sovetskoi Provintsii :1937-1938 massovaia 


\section{Bibliography}

operatsiia na osnove prikaza, No. 00447 (Moskva, Rossiskaia Politicheskaia entsiklopedia, 2009).

Smith, Steven, Red Petrograd: Revolution in the Factories, 1917-1918 (New York: Cambridge University Press, 1983).

Stites, Richard, Revolutionary Dreams: Utopian Visions and Experimental Life in the Russian Revolution (New York: Oxford University Press, 1989).

Tret'iakov, G. I., "Soobshcheniia. Vsenarodnoe obsuzhdenie proekta konstitutsii SSSR,” Voprosy istorii, No. 9 (Sept. 1953), 97-102.

Tucker, Robert, Stalin in Power: The Revolution from Above, 1928-1941 (New York: W. W. Norton and Company, 1992).

van Ree, Erik, The Political Thought of Joseph Stalin: A Study in Twentieth Century Revolutionary Patriotism (Richmond: Curzon, 2002).

Viatskii Krai $v$ rubezhe tysiacheletii: istorii $i$ sovremennost' (Kirov: komitet gosudarctvennye statistiki, 2002).

Viola, Lynne, Best Sons of the Fatherland: Workers in the Vanguard of Soviet Collectivization (New York: Oxford University Press, 1987).

Viola, Lynne, "The Peasant Nightmare: Visions of Apocalypse in the Soviet Countryside," The Journal of Modern History, Vol. 62, No. 4 (Dec. 1990), 747-770.

Wimberg, Ellen, "Socialism, Democratism and Criticism: The Soviet Press and the National Discussion of the1936 Draft Constitution," Soviet Studies, Vol. 44, No. 2 (1992), 313-332.

Wood, Elizabeth, Performing Justice: Agitation Trials in Early Soviet Russia (Ithaca, NY: Cornell, 2005).

Zagvozdkin, G.G., “Triumf i Tragediia v 30-kh godov," Istoriiia Ensiklopediia zemli Viatskoi, tom. 4 (administratsiia kirovskoi oblasty,viatskaia torgovopromyshlennaia palata, 1995).

Zelenin, I. E., “Byl li ‘Kolkhoznyi neonep’?” Otechestvennaia istoriia, No. 2 (Apr. 1994). 


\section{Index}

2nd Congress of Stakhanovite-Shock Workers 86

7th Congress of Soviets (1935) 17, 20, 63

8th Congress of Soviets (1936) 14, 16, 21, 127-8

“17th Party Conference" collective farm 127

25,000ers 5, $11 \mathrm{n} 18$

1918 Soviet Constitution (1st) 21-2, 24,63

1924 Constitution 17, 22, 24, 63

1934 Party Congress ("Congress of Victors") 12

Abramovich (church member) 126

Abramycheskii rural soviet 77-8

accountability and competence, of local officials 9, 25, 85, 110, 114-20, 122n $51,143-4$

Agafokov, Comrade 133

Agalakov, Aleksander Vasil'evich 53-4 agitprop work, pro-Soviet $16,36 \mathrm{n} 35$, 65-6, 69-70, 76-7, 80, 87, 128-9, 131 ; see also aktiv

agriculture 40-2, 45, 49-52, 56, 104-6; see also collective farms

aktiv 66-8, 70, 72, 79, 127; see also agitprop work, pro-Soviet

Akulov, Ivan 17, 124, 142, 144

Alferovskii agricultural artel' 97

All Union Communist Party 128-9

Alymov, Comrade 63

Anisimov, Comrade 71

anti-Soviet activity 9-10, 141; and the elections of 1937 127-35, 137n27, $138 \mathrm{n} 58$; during the public discussion 123-7

Arbazhskii district 119

archives 2-3, 12, 14, 18, 62-3, 143, 164
Articles: Article 1 19, 97, 146; Article 2 19-20, 146; Article 3 20, 146; Article 6 27-8, 104, 146; Article 7 28, 105-6, 146-7; Article 8 93, 104, 147; Article 9 104-5, 147; Article 10 20-1, 147; Article 11 80, 147; Article 49 81n13, 151; Article 95 116, 158; Article 109 93, 107n7, 159; Article 119 93, 98, 160; Article 120 87, 93, 98-9, 160; Article 121 80, 93, 95, 161; Article 127 53-4, 93, 113, 161; Article 131 113, 162; Article 132 93, 95-6, 107n7, 162; Article 135 93, 111, 162; Article 142 93, 107n7, 163 ; second article on citizens' rights, proposed 23

articles and speeches, for lessons on the draft Constitution 62-4

Arziaev (party member) 116

Azim'ia village 50

Baklanov, Comrade 78

Balanyrinskii rural soviet 127

Basharskii rural soviet 71

Batyrev (chairman) 132

Bazhutin (party member) 115

Biserovskii raion 43, 134

Bobkov, Aleksandr Alekseevich 143-4

Bogomolov (party member) 96

Bogorodsk 54

Bogorodskii raion 71, 77-8

Bolshevik (newspaper) 63

Bolsheviks 5, 14-16, 19, 21, 26-7, 40, 43-4, 63, 72, 79

Bolshoi Shoromovskii collective farm 77

Borodin, Filipp 87, 89

Braturkhin, A. I. 53

Braturkhin, M. I. 53

"Bubnov" collective farm 55-8 
Buckley, Mary 68

Bukharin, Nikolai 3, 14, 17, 18

Buldakov, Arkadii Semenovich 47

Buldakov, Trifon Grigorivich 47

bureaucratism 15-16, 23-5, 31, 37n59, $71,77-8$

Burkovskoi Elementary School 101

Bystrov, Comrade 133

cattle see livestock

Central Executive Committee, Moscow: and anti-Soviet activity 124, 127, 133-5; and the drafting of the Constitution 17; and multi-candidate elections 16; popular suggestions submitted to $89,93,101-4$; relations with local and regional officials 3 , 142-4; role in implementing the public discussion 65-6

central state leadership: and anti-Soviet activity 123-5, 128-9, 133, 135; and the drafting of the Constitution 12-16, 19, 21-2, 25-6, 28-9, 31-3; and the goals of the public discussion 1-7, 139-40; and law and order 112-14; and the public discussion $62-5,68,71,74-5,78-81,84,89$

Chekov, Anton 103

Cherepanov (collective farmer) 99

Cherepanov, A. I. 53

Cherepanov, A. N. 53

Cherepanov, Aleksander 53

Cherepanov, P. A. 53

Cherninov, I. M. 125

"Chernousy" collective farm 55

children 27, 31-2, 49, 69, 86-7, 95, 97, 101, 103, 106

Chinese people 65

Chiudinovskikh, S. A. 135

church, the 26, 44, 111, 126, 132, 161

citizens' duties and obligations: as delineated in the draft Constitution 19, 22-3, 29-33, 161-2; to do military service 32-3, 95-6, 162; see also social contract, reciprocal nature of

citizens' rights and privileges 2, 7-10; as delineated in the draft Constitution 19, 22-31, 160-3; letters to local newspapers concerning 85-9; popular suggestions concerning 92-107

citizenship, re-definition of 7-9, 13, 19-22, 33, 63, 94, 107, 128, 140; see also electoral franchise, expansion of
Civil War 6, 26, 41-4, 64

class enemies 4, 10, 12-13, 22, 120n1, $123-5,127-9,133-5,140$

classes 19-21, 63, 89

clergy see priests

Cohen, Stephen 18

collective farm chairpeople: and the implementation of the public discussion 71-2, 77-80; and letters to the local press $8,84,88$

collective farm workers: and the 1937 elections 129-32, 134; and antiSoviet behavior during the public discussion 125-7; and challenges against injustice 54-8; on cow ownership 49, 105-6; daily realities in Kirov 41, 43, 46-58; on the expansion of the electoral franchise 111-12; expulsions 46-8, 100; and land rights 104-5; on law and order 112-16; on local officials 116-19; on military service 95-6; popular suggestions to the draft Constitution 8-9, 89, 94, 97-106, 140; and property 29-30, 105-6; and public discussion meetings $62,66-71,73-5$, 77-81; rights of 20-3, 26-30; Soviet supporters 85-8; see also collective farms

collective farms 6, 29-30, 41, 44-8, 65, 146-7; Honor Roll 49-50; see also collective farm workers

collectivization 4-6, 9, 12, 22, 29-30, 40, 48, 51, 102, 104, 106, 126, 130; 25,000 ers $5,11 \mathrm{n} 18$; rates of, in Kirov region 46; in Viatka 44-5

"Combine" artel' 100

Comintern leather factory 72

Committees of the Poor (kombedy) 6, 44-5

Communist Party: archive, Kirov 2; and popular participation 5, 15-16, 23-4; see also central state leadership; district Party committees; Regional Party Committee

Congress, 1934 Party ("Congress of Victors") 12

Congress of Soviets (1935), 7th 17, 20, 63

Congress of Soviets (1936), 8th 14, 16, 21, 127-8

Congress of Stakhanovite-Shock Workers, 2nd 86 
congresses of Soviets, fall 193673

Constitution (1918) 21-2, 24, 63

Constitution (1924) 17, 22, 24, 63

Constitution, drafting of the 1936

12-33; citizens' duties and obligations

31-3; citizens' rights and privileges

22-31; constitutional theory in the

USSR 7, 13-16, 63, 106, 139-40;

defining citizenship 19-22; overview

of the process 17-19, 36n33

Constitution, ratification of the 1936 3-4, 17, 106, 128-31, 135

Constitutional Drafting Commission 1, 14, 17-18, 21, 23-4, 26-7, 29-30, $32,35 \mathrm{n} 20$

constitutional theory, European 14 constitutional theory in the USSR 7, 13-16, 63, 106, 139-40

corruption 9, 15, 31, 52, 110, 118

"Country of the Soviets" collective farm 131

countryside 31, 128-30, 135, 137n27; see also collective farm workers; collective farms; rural-urban divide crime 9, 32, 52-4, 104, 110, 112-14, 141

Daregorodneva, Comrade 99

Darovskoi raion 96

Davies, Sarah 2-3, 92-3, 110

"Dawn of Freedom" collective farm 55, $57-8$

"Declaration of the Rights of Man and of the Citizen" 14

democracy 9, 13-16, 110-11, 116, 128, 130; Soviet 13, 20, 34n9, 64, 89, 102, 141

deputies, elected 116-19, 133-4

discussion of the draft Constitution see public discussion of the draft Constitution

disenfranchised, formerly ("former people”) 9, 13, 19, 87, 89, 110-12, 119-20, 127-9, 133, 135

district executive committees (raiispolkom) 66-7, 71-2, 77-8, 80, 89, 117, 119, 127, 143; Zuevskii District Executive Committee 54-8 district Party committees (raikom) 57-8, 66-7, 72, 74-5, 77-8, 129, 131-2, 138n58, 143

District Roads Department, Zuevskii raion 54-7

Dokuchaev, Inspector 47-8
Dokuchaev, Ivan 98

draft Constitution: overview 1-10; as reciprocal social contract $1,6-7,33$, 63-5, 88-9, 92-3, 139-41; “working up" (prorabotka) of the 71, 77-9, 81; see also Constitution, drafting of the 1936; popular suggestions to the draft Constitution; public discussion of the draft Constitution

drafting of the Constitution see Constitution, drafting of the 1936

Dubovskikh, Mikhail Ivanovich 57

Dubrovo village 99

duties and obligations, citizens' see citizens' duties and obligations

“Eastern Dawn” Artel' 99

education: civic 63; in Kirov in the 1930s 41, 43-4; legal 115; the right to equal access to $9,21-2,26-8,64$, 86, 93-5, 97, 110, 160; technical 80

elections (1937) 9, 12, 14-16, 51, 93, 119-20, 123, 127-35, 137n27, $138 \mathrm{n} 58$

elections, multi-candidate 15-16, 24, $35 \mathrm{n} 24,63,123-4,129$

elections (1936), local 9, 110-12, 116-17, 119, 123, 126-7, 135

electoral franchise, expansion of 10 , 15-17, 22, 33, 110-12, 124, 127, $129,140-1,162-3$

Elsukov (party member) 114

enemies: class 4, 10, 12-13, 22, 120n1, 123-5, 127-9, 133-5, 140; of the people $32,52,112-14,131$; of the state 9, 15-16, 31-3, 35n24, 98, 142 enlightenment, programme of 26-7

Enlightenment, the 14

Eprinskii collective farm 77

Erofeev, V. A. 115

Eternal Usage of Land, Act on the 54-6, 104

"Excavator" collective farm 127

factories 26-7, 41-3, 115; discussion meetings in $67,72-6$

Falenskii raion 48-9, 97-8, 133

Fir Ovsizhnikov 129

"First of May" collective farm 49, 105

Five-Year Plan, first (1928-1933) 41-3, 51, 94

Five-Year Plan, second 43-4

Five-Year Plans 13, 42, 44 


\section{Index}

"Flame of Revolution" collective farm 48

Forest Factory No.2, Kirov 76

Frank, Stephen 104

freedom: of assembly 24-5, 161; to criticise the state and officials 24-5; to demonstrate 24-5, 161; to engage in anti-religious propaganda 26 ; to engage in propagandistic activities 25-6; of the press 24-5, 88, 95, $125-6,161$; of speech $24-6,88,92$, 125,161

Gagarinkov, Comrade 112 gender 19, 21, 93-4; see also women Germany 96

Getty, J. Arch 3, 16, 18, 35n24, 92-3, $124,128,135$

Glazov 41, 47

Glukhikh, Comrade 76

Gontsov, A. F. 117

Gontsov, Egor Avdeevich 125

Gorky region (Nizhny Novgorod) 40, 45-6

Gredenevskii production collective farm $49-50$

Gromov, Instructor 70

Gusak, A. 88

habeas corpus 9, 30-1, 53-4, 89, 93, $110,112-13,119,141$

Hazard, John 13

healthcare 22, 27-8, 79, 87, 89, 98, 100,160

Hicks, Jeremy 85

Hier, Charles 6

Holmes, Larry 6

Honor Roll collective farms 49-50

hooliganism 52-4, 89, 113-14

Howard, Roy 15

Hughes, James 5-6, 47

Iabloko, Comrade 72

Iablokov, P. A. 66

Iakimova, Elizaveta Vasil'evna 72

Iakovlev, Iakov Arkaidiovich 18-32, 36n33, 36n34, 106

Iaransk 42, 77, 99

Iaranskii raion 77, 78, 130

Il'in, D. (Stakhanovite worker) 112

industrial workers 41-3, 74-5, 88

industrialization 4, 12, 30, 40-3, 123

industry $29,41-3,50,67,76$

Istomin, Comrade E. M. 100
Iuferov, Stepan Dorofaevich 88

Izhevsk 41, 88

Izhstal' zavod 88

Izvestiia (newspaper) 14, 62-4, 70

Japan 96

judicial system 13-14, 19, 22, 29, 31, $54,93,112-16,121 \mathrm{n} 38,158-60$

Kaiskii Gornorabochii (newspaper) 117-18

Kaiskii raion 46, 133

Kalinin, Mikhail 14, 17, 124, 142, 144

Kalinin collective farm 105

Karakulinskii raion 46, 99

Karavaev, Dmitrii 53

Karavaev, Pavel D. 53

Karavakov, R. M. 53

Kasbianov, Comrade 133

Kharin, M. T. 126

Kharinskii rural soviet 130

"Khimik" collective farm 98

Khlust'ianov (Party member) 134

Khromonii factory 125

kindergartens/nurseries 21, 49-50, 103

Kir'ia village 129

Kirov, Sergei Mironovich 40

Kirov city (formerly Viatka) 41, 44, $62-3,67,73,76,78$

Kirov (formerly Viatka) region: background 2, 6-7, 40-4; daily life on collective farms 44-58

Kirov Regional Forest Administration 1,92

Kirov TASS 77-8

Kirovets (newspaper) 52

Kirovskaia Pravda (newspaper) 8, 56-8, 70-2, 85-9, 90n15, 94

Kirovskii raion 46, 66, 73, 106

Kirs 132

Kislitsin, Fedor Stepanovich 100

Kokorovshinskii rural soviet 99

Kolchak, Alexander Vasilyevich 42

Kolkhoznaya Zaria (newspaper) 71

Kolomytsev, Comrade 131

Kolosov, V. Ia 113

Komsomol 23, 53, 66-7, 70, 125

Komsomolskaia Pravda (newspaper) 63

Kopanev (controller at KUTShO) 87

Koppashinskii rural soviet 125

Kora village 129

Koriakinskii rural soviet 116 
Korobintsyn, S. A. 126

Kotel'nicheskii raion 78

Kotel'nikov, Comrade 53

Kotkin, Stephen 4, 14, 79

Kozel, Comrade 135

Kozlakh village 130

Koz'minykh (medical asst) 125

Kraiispolkom see Regional Executive Committee

Kraikom see Regional Party Committee

Krasinskii collective farm 49

Krasnoperov, Yuri Alekseevich 103-4

Krylenko, Nikolai 13-14, 15, 35n16, 70

Kudrevatykh (collective farmer) 112

Kudrin (party member) 105

kulaks (prosperous peasants): and the 1937 elections 9, 12, 123, 127-8, 131-5; and anti-Soviet behavior during the public discussion 126-7; exclusion of $110-11,114,120 \mathrm{n} 1,120 \mathrm{n} 10$; poor peasants and 5, 44; re-enfranchisement of $7,9,13,16,33,140$

Kumenskii raion 126

KUShTO Combine 76

Kustarka artel' 75

KUTShO Combine 76, 87

Kuvakushska village 132

Kuznetskii artel' 80

Kuznetsov, Comrade 56

L. Komarovskii rural soviet 119

Labor Code 27-8

laborers 63, 69-70, 88, 99, 112, 115-17; in the Constitution 147, 160-2; and the definition of the USSR 19-20, 37n45, 65, 97; in the draft Constitution 22-9, 32

land rights $104-5$

land usage 54-8, 93-4, 104-5

Laptev, Veniami Ignat'evich 72

law and order 112-16, 121n38

Lebiazhskii raion 52, 80

lectures, on the draft Constitution 44, 62-70, 76, 79; topics 64-5

Lenin, Vladimir Ilyich 21, 65

Leningrad 42

Leninskii Put' (newspaper) 53-4

Leninskii rural soviet 77

Lenoe, Matthew 85

Lepekhin, Instructor 77

lesson plans and syllabi, on the draft Constitution 8, 62-5, 80-1, 85, 118,140 lishentsy 9, 111-12, 128

livestock 45-9, 51-2, 57, 86, 105-6

living standards 50-1, 64-5, 86-9, 97-8, 106, 118, 125

local governance: in Kirov in the 1930s 40, 43-4, 51-3; problems with 2, 5-6, 15-16; see also local officials

local officials: and the 1937 elections 127-9, 131-2, 135; accountability and competence of $9,25,85$, 110, 114-20, 122n 51, 143-4; and anti-Soviet behavior during the public discussion 125-7; and the implementation of the public discussion $3,8,62,66,68-71,73$, $77,79-81$

logging enterprise, Zuevskii raion 54, 56-8

Loginov, Anton Nikolaevich 132

Lotapov (member of raiispolkom) 119

Lozhkin, Nikolai Iosifovich 51

Luzinskii collective farm 56-7

Machine Tractor Station (MTS), Zuevka 45

Magnitogorsk 4

Makhnev, Comrade 57

Malmyzh 42

Malyshenki village 115-16

Manning, Roberta 66

Markov, I. K. 105

Marxist-Leninist: Constitution 63; doctrine 65

"Mashinostroitel” artel' 77

Mashkovtsev, I. E. 115, 116

Maslennikov (discussant) 111

Maslov, Inspector 144

medical benefits 22, 27-8, 79, 87, 89, 98, 100, 160

Mekhlis, Lev 14

Mekhovshik 75

Mel'nikov, Ia. I. 53

Men'shkov, I. F. 87

Mesheriakov (party organizer) 95-6

migratory labor 41-3

Mikriukov (from Basharskii rural soviet) 71

Mil'chakov, Mikhail Ivanovich 48

Mil'chakov, Nikolai Gerasimovich 48

Miliaev, Instructor 77

military service $32-3,93-7,162$

militsia 52, 133

Mineevskii rural soviet 118 


\section{Index}

Mironov, Comrade 79-80

Molotov, Vyacheslav 14, 16-17, 20, $35 \mathrm{n} 15,63$

Morozov (local official) 118

Morozovskii rural soviet 74

Moscow 2-3, 9, 42, 116, 122n51, 124-5, 127, 130, 140-4; see also Central Executive Committee; central state leadership

Murashinskii raion 46, 119, 128

Murashinskii raion supply union 114

Murav'ev (collective farmer) 112

Mykhin, Comrade 126

nationality, citizenship and 19,21 , 160,162

Natiunicha village 135

Nazarov (author) 70

Nazarovskii rural soviet 119

Nekrasov, P. I. 126

NEP period 26, 43-5, 104

"New Construction" collective farm 86

newspapers: articles used in lessons on the draft Constitution 62-4; and the implementation of the public discussion 62, 68-73, 80-1, 140; letters to local/regional 8, 84-9, 92; reports of local concerns in $7,52-5$, 57-8; see also individual newspapers; press freedom

Nikolaevsky, Boris 18

Nikulin, Comrade 57

Nikulin, N. F 112

Nikulitskii rural soviet 53

"Niva" collective farm 127

Nizhny Novgorodskii Krai 40

NKVD 9, 52, 67, 111, 123, 126, 128, 131, 133-5

Nolinsk 42

Nolinskii district Party cell of the NKVD 128-9, 131

Nolinskii raion 52, 98

Norodskii soviet 73

Noskov (former kulak) 129-30, 132

Novikov, N. 143-4

nurseries/kindergartens 21, 49-50, 103

Obatin, Iosif Andreevich 95

October artel' 114

Odegov, S. P. 116

Ogorodnikov, I. Ia 53

Ogorodnikov, S. V. 125

Ogorozhnikov (rural soviet member) 53 old age benefits and pensions 28,79 , 87, 89, 93-4, 98, 100-3, 109n51

Omutninsk city 132

Omutninskii raion 69-70, 94, 111, 130-1, 132-3

organizers, of the public discussion 8 , $65-8,80$

Ovchinnikov (collective farmer) 112

Ovechkin, Timofei 101-4

Ovsizhnikov, Fir 129

passports $134,138 \mathrm{n} 54$

peace, international struggle for $64-5$, $81 \mathrm{n} 13$

peasants 5-8, 140; and benefits and rights 27-8, 97; daily life in Kirov 40-1, 43-7, 49; and grievances 102, 104-5, 110, 112, 118, 125; and the implementation of the public discussion 63-5, 80; separation of workers and 19-21, 64-5, 89, 97-9; see also collective farm workers pensions and old age benefits 28, 79, 87, 89, 93-4, 98, 100-3, 109n51

Piatin, N. I. 117

Pizhanskii raion 67-9, 70, 72, 118-19

Plastinina, Paraskovia 130

Pliner, Maria Semenova 55

Plotnikov, I. P. 112

Polom village 130

Polonin (local official) 118

Polushin, Comrade 133

Poninskii raion 49

Popular Front movement 65

popular suggestions to the draft Constitution 2, 8-10, 74-5, 92-107, 110-20, 139-44; on the accountability of local officials 114-20; on anti-Soviet behavior 123-7; on citizens' rights 92-107; on cow ownership 49, 105-6; on the expansion of the electoral franchise 110-12, 119-20; "inappropriate" and "irrelevant" suggestions 8, 62, 74, 79-81, 89, 124, 143-4; on land rights 104-5; on law and order 53-4, 110, 112-14; on the military 93, 95-7; on state responsibility 100-4

"povinost" (obligation) 95-6

Pravda (newspaper) 14, 36n36, 62-3, 70, 144, 146

pre-revolutionary period 41-3, 45, 64, $84,94-5,110$ 
Presnetsov, Comrade 72

press freedom 24-5, 88, 95, 125-6, 161

press see individual newspapers;

newspapers; press freedom

priests $7,33,89,110-11,123,126$, 131-2, 134-5, 140

Proletkult movement 26-7, 38n79

property: collective 29-31, 47, 52, 1467; of the disenfranchised $5,110-11$; personal 6, 22, 29-30, 48, 105-6, 112 , 147; socialist $31-2,39 \mathrm{n} 111,64$, 89, 113-14, 118, 146, 162

property rights 29-30, 94, 105-6, 147

Prosnitskii raion 78-9

public discussion of the draft Constitution $62-81$; implementation of the $3,7-8$, $62,65,68-75$; lesson plans and articles $8,62-5,80-1,140$; in the local press $8,84-9$; organizers of $8,65-8,80$; overview 1-4, 6-7, 140; problems with $62,76-81$; see also popular suggestions to the draft Constitution

"Pushkin" collective farm 55-7

Putin, Vladimir 93

racial equality 19, 21-2, 160, 162

Radek, Karl 14, 17

radio listening sessions $69-70,75,80$

raiispolkom see district executive committees

raikom see district Party committees

"Reconstruction" collective farm 50

Red Army, Workers' and Peasants' 26, 33, 42, 95-6, 162

"Red Column" collective farm 50-1

"Red Falcon" agricultural artel' 119

"Red Hill" collective farm 127

"Red October" collective farm 97

"Red Putilovets" collective farm 52-3

re-enfranchisement see electoral franchise, expansion of

regional authorities $6,16,24,52,62$, $77,81,106,124,139$

Regional Executive Committee (Kraiispolkom): and collective farms $48,50,56-8$; and the implementation of the public discussion 65-6, 73, 77; and popular suggestions to the draft Constitution 89, 143-4; reports on local officials 117, 119

Regional Forest Administration 1, 92 regional leaders $16,35 \mathrm{n} 24,68,128$, 137 n 25 regional officials: and the 1937 elections 128-9, 132, 135; and anti-Soviet behavior during the public discussion 124-6; and the implementation of the public discussion $62,72-3$, 76-7, 79-80, 84, 142-4; and popular suggestions 8,12

Regional Party Committee (Kraikom) 48, 63-6, 69, 73, 77, 79-80, 128, $130,135,138 \mathrm{n} 58,143$

"Regulations on Elections" 135

religion 9, 26, 40, 110-12, 114, 120n1, 120n5, 125-6, 131-2, 134, 161

repression of 1937-38, mass 9-10, $12-13,17,123-4,135,141$

Retish, Aaron 6, 44-5, 104

Riakin (chairman) 133

right to: assembly 24-5, 161; criticize the state and officials 24-5; demonstrate 24-5, 161; education 9, 21-2, 26-8, 64, 86, 93-5, 97, 110, 160; financial/material aid 26-9, 33, 64, 87, 107, 160; free press $24-5,88$, $95,125-6,161$; free speech 24-6, $88,92,125,161$; healthcare 22, 27-8, 79, 87, 89, 98, 100, 160; pensions and old age benefits 28,79 , 87, 89, 93-4, 98, 100-3, 109n51; property 29-30, 94, 105-6, 147; racial equality 19, 21-2, 160, 162; vacations and rest $9,26,28,79-81$, 93-4, 97-100, 160; vote 16, 19 , 21-2, 86-9, 93, 110-12, 117, 127-8, $131,135,162-3$

rights and privileges see citizens' rights and privileges; right to

R-Mureka village 102

road project, Zuevskii raion 54-6, 58, 94

Rodygin (Trotskyist) 135

Rodygino village 135

Romanov, Comrade 127

Rosa Luxemburg collective farm 85-6

RSFSR (Russian Socialist Federated Republic) 10, 15, 24, 123

rural residents see collective farm workers; peasants; rural-urban divide rural soviets: and the 1937 elections 129-30, 132-4; and anti-Soviet behavior during the public discussion 125-7; and elected officials 116-19, 142; and fear of lishentsy 111; and the implementation of the public 
discussion $66-7,71-2,74,77-8,80$; and social courts 115

rural-urban divide $2,8,43,67-8,75$, 84-5, 97-101, 105

Rusinov, S. A. 99

Samodurov (priest) 132

Sanchurskii raion 126

Sapozhnikov, Comrade 55-7

Sarpul' 103

"Saturday" collective farm 54-5

schools 6, 15, 26-7, 43-4, 64, 66, 69, 95,$101 ;$ see also education

"Science" collective farm 88

Sechevka raion 6

"Second Five-Year Plan" collective farm 49

Semenudrskii rural soviet 119

service workers $28,64,69,80,88$, 98-101, 105, 114

Shabalin, D. A. (party member) 111

Shabalino 131

Shabalinskii raion $66-7,70,88$

Shakhnery village 115-16

Shennikov, Aleksei 57

Shestakov, N. P. 131

Shevnin, N. 72

Shkurikhin, Comrade 127

Shurminskii raion 101

Shvernik, Nikolay 70

Shvrina, Taisiia Nikolaevna 88

Siberia 5-6

Sidorov (psalm reader) 132

Siegelbaum, Lewis 4, 5

Sitka village 99

"Sitniki" collective farm 98

Sitnikov (party member) 98

skilled workers 27

Slobodkinskii rural soviet 119

Slobodskoi city 74-5

Slobodskoi forest production enterprise 80

Slobodskoi raion 42-3, 53, 65-7, 70, $74-7,80,98$

smallholders 29, 45-6, 48, 104-6, 125-7, 130, 132

Smertinia, A.P. 86

Sobin (smallholder) 127

social contract, reciprocal nature of the $1,6-7,33,63-5,88-9,92-3$, 139-41

social services and welfare $14,22,26$, 63-4; see also right to
"Socialism" collective farm 50

Sokolov (from Sovetsk) 99

Sokolov, Andrei 3, 4

Solomon, Peter 13-14

Sovetskii raion 69,133

Soviet leadership see central state leadership

Soviet of Nationalities 131

Soviet of the Union 130-1

"Sower" collective farm 126

Sozinov, Ivan 117

Sozinov, V. I. 117

Sozonov, Comrade I. V. 100

Sozontov, Comrade 76

Spanish Civil War 96

Spanish people 65

"Spas" fur factory 75

speeches and articles, for lessons on the draft Constitution 62-4

"Squirrel" Fur Factory, Slobodskoi raion 42,74

Stakhanovite movement 4-5, 7-8, 42, $65,68,72,84-7,99-100,112,117$

Stalin: and the 1937 elections 127-8, 130, 133; and the accountability of local officials 9 , 110, 114, 116; and the delineation between workers and peasants 19-21, 89; and the drafting of the Constitution 12-33, 34n9, 36n33, $37 \mathrm{n} 45$; and the mass repression of 1937-38 12-13; and patriarchal values 94; praise for 51, 85-6, 102; see also Stalinism; Stalinist state-building, public discussion of the Constitution as part of

Stalin collective farm 78

Stalinism 3

Stalinist state-building, public discussion of the Constitution as part of 1-8, 139-40

Stalinskii district, Kirov city 76

Stasovoi artel' 126

State Archive for the Kirov Region (GAKO) 2

State Archive for the Social and Political History of the Kirov Region (GASPI KO) 2

State Archive of the Russian Federation 18

"Stepan Razin" collective farm 106

Stetskii, Aleksei Ivanovich 18-32, 36n33, 36n35, 63, 69-70, 106 
Stolbova (collective farmer) 95

Stoliar, Comrade 73

students $26-7,44,62-4,66,79,95$

study circles, to discuss the draft

Constitution 62-3, 66-7, 70, 72,

74-6, 80, 81n13

Stulovskii rural soviet 77

suggestions to the draft Constitution see popular suggestions to the $\mathrm{draft}$ Constitution

Sumaneeva, N. 85-6

Supreme Soviet 15, 116, 119-20, 123, $127,129,132,135,150-3$

"Surf" artel' 100

Taiarikov (collective farmworker) 125-6

Tal', Boris Markovich 18-32, 36n33, 36n36, 106

Tantarov, G. E. 78

Tarasova, Nina 116

Tashlykov (member of raiispolkom) 119

taxes 48, 87, 97, 105, 108n47, 119, $125-7,130$

teachers 66-8, 101

Teplykh, Comrade 100

"Thirteenth Anniversary of October" collective farm 117

Tret'iakov, G. I. 3

Troshkov, V. A. 100

Trotsky, Leon 132

Trukhin, S. P. 99

Trushchkov, Aleksei 96

"Truth" collective farm 113

Tsarist Russia 12, 40-3, 51, 86, 95-6, 118, 125

Tubylov, Matvei 86

Tucker, Robert 2, 3, 24

Udmurt Autonomous oblast' 50

Uiferev, Comrade 133-4

Uninskii district 132

"Union" collective farm 50

unions $1,8,23,66,80,126,136 \mathrm{n} 15$

universal suffrage 14-16, 35n24, 127

Upolnomochennskii rural soviet 127

Ural-Siberian (social influence)

method 5-6

urban areas 41-2, 67-8, 73-5, 80, 97

urban residents $2,8,41,43,64,67$, 75, 84-5, 97-8, 101, 105, 108n26, 139,142

urbanization 40-2, 46 urban-rural divide $2,8,43,67-8,74-5$, 84-5, 94, 97-101, 105, 139

Urzhumskii raion 52

Ushakov, Mikhail Ksenofonich 48

Ushakova, Anastasiia Stepanovna 47

USSR 1, 3, 4-5, 13, 65, 80, 81n13, 93, 125; Soviet Constitutional theory 7, 13-16, 63, 106, 139-40; see also Constitution, drafting of the 1936

Ustiugov, Ivan Sergeevich 95

Ustiuzhanov (former kulak) 131

Utrobin, Semyon Teren'evich 72

vacations and rest, the right to 9,26 , 28, 79-81, 94, 97-100, 160

Vakhnin, M. 71

Veprevskii rural soviet 71

Verkhoshizhemskii raion 46

Viatka (later Kirov) 6, 11n24, 40-5, 51, 94, 104

violence 42, 52-3, 112-14, $126-7,129$

Vladimirov, Comrade 133

Vladimirovskii rural soviet 78

Volkovskii rural soviet 74

Vorob'ev, M. N. 113

Voroshilov farm 53, 88

voting rights $16,19,21-2,86-9$, 93, 117, 127, 131, 135, 162-3; opposition to $16,110-12,127-8$

Votkinsk 41-2

Votkinskii Machine Building Factory 42

Votkinskii power plant 105

Votkinskii raion 62, 73, 119, 126-7

V. Sludka collective farm 47, 49

Vyshinsky, Andrei 14, 17, 30, 34n7, 70,115

"Wave 2"collective farm 51

white-guardists 16, 127, 133

Wimberg, Ellen 3

women 21-2, 27, 33, 64, 76, 78, 85-6, 93-8, 108n26, 160, 162

workers: industrial 41-3, 74-5, 88; and peasants, separation of 19-21, 64-5, 89, 97-9, 105; service 28, 64, 69, 80, 88, 98-101, 105, 114; skilled 27; see also laborers

workers' and peasants' correspondents movement 85

Workers' and Peasants' Red Army 26, $33,42,95-6,162$ 


\section{Index}

working class 20-1, 63, 79, 99, 110 working hours 27-8, 50, 78, 80, 97 "working up" (prorabotka) of the draft Constitution 71, 77-9, 81 World War II 96, 141

Yel'tsov, Aleksei Vasil'evich 47 youth 23, 26-8, 131

Zabodkin, Comrade 128

Zaleshin (party member) 115

Zaozerskii rural soviet 126 zemstvos 6, 41, 43, 45, 94 Zhdanov, Comrade 134 Zhdanov, Inspector 55-7 Zherekhov, Comrade 128 Zhuikov, L. M. 105 Zhuravlev, Bishop 132 Ziuzdinskii district 129-30, 131-2 Zubartov, Comrade 76 Zuevka (Zuevskii) District Executive Committee 54-8

Zuevskii raion 45, 54, 94, 134

Zuizdinkskii raion 45, 51-2 